\title{
SOME TYPES OF IRRIGATION FARMING IN UTAH
}

A THESIS SUBMITED TO THE FACULTY OF THE GRADUATE SCHOOL OF THE INIVERSITY OF MINNESOTA

By

EDGAR BERNAFD BROSSARD, B. 8., M. S.

IN PARTIAL FULFLLMENT OF THE REQUIREMENTS FOR THE DEGREE OF DOCTOR

OF PHILOSOPHY

June, 1920 


\section{SOME TYPES OF IRRIGATION FARMING IN UTAH \\ By}

E. B. BROSSARD

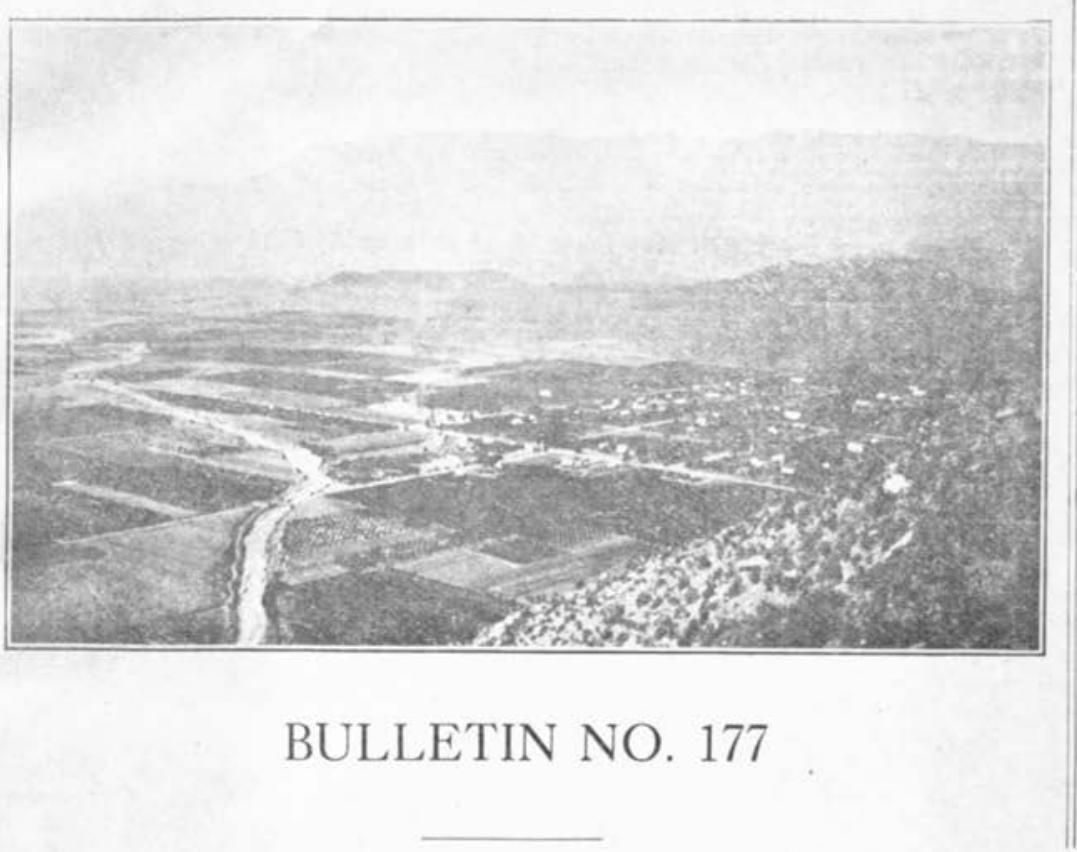

\section{Utah Agricultural College EXPERIMENT STATION}




\section{UTAH AGRICULTURAL EXPERIMENT STATION}

BOARD OF TRUSTEES

A. W. IVINS

JOHN DERN.

LORENZO N. STOHL

JOHN C. SHARP.

ANGUS T. WRIGHT

GEORGE T. ODELL.

Salt Lake City Salt Lake City ...Salt Lake City Salt Lake Cits Ogde:

A. G. BARBER

LOIS C. HAYBALL

Salt Lake City

Logan

FRANK B. STEPHENS

JOHN D. PETERS.

W. S. HANSEN

GEORGE W. SKIDMORE

HARDEN BENNION, Secretary of State, (Ex-officio)

Salt Lake City

Brigham City

Fielding

Logan

OFFICERS OF THE BOARD

A. W. IVINS

Salt Lake City

JOHN DERN

President

JOHN L. COBURN

Vice-President Secretary and Trensurer

EXPERIMENT STATION STAFF

E. G. PETERSON, Ph. D., President of the College

F. S. HARRIS, Ph. D.

Director and Agronomis:

WM. PETERSON, B, S

Geologist

H. J. FREDERICK, D. V. M

Veterinarian

F. L. WEST, Ph. D.,

Physicist

J. E. GREAVES, Ph. D.

W. E. CARROLL, Ph. D.

Chemist and Bacteriologist

BYRON ALDER, B, S

Animal Husbandman

Poultrymau

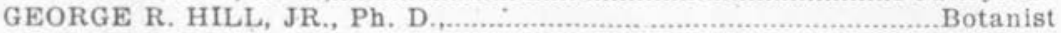

O. W. ISRAELSEN, M. S............................... Irrigation and Drainage Engineer

M. C. MERRILL, Ph. D.

Horticulturist

D. S. JENNINGS, Ph. D Soil Survey

R. J, BECRAFT, B. S.

Range Management

GEORGE STEWART, M. S.

R. L. HILL, Ph. D.

Range Management

E. B. BROSSARD, Ph. D.

GEORGE B. CAINE, M. A.

C. T. HIRST, M. S.

WILLARD GARDNER, Ph. D.

B. L. RICHARDS, Ph. D....

BLANCHE COOPER, B. S.

EZRA G. CARTER, M. S.

M. D. THOMAS, B. S., B. Sc.

D. W. PITTMAN, M. S....

T. H. ABELL, M. S.,

A. F. BRACKEX. B. S..

Human Nutrition

Farm Management Dairying Associate Chemist Associate Physícist Associate Botanist YEPPA LUND, M. S.... L. F. NUFFER, B. S., ARTHUR FIFE, B. S.

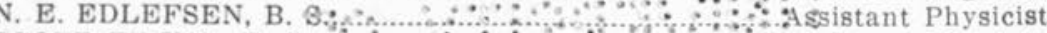

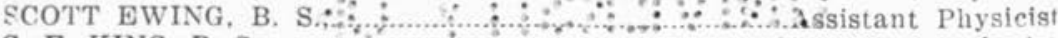

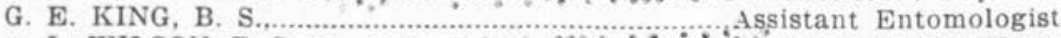

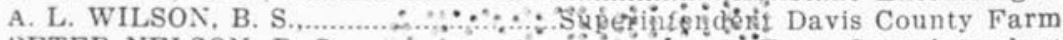
PETER NELSON, B. S.,...........

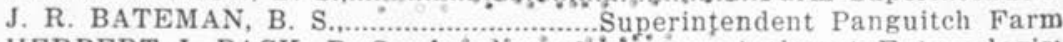

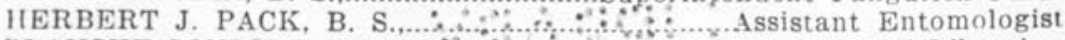
BLANCHE CONDIT PITTMAN, A, B k. B. SAULS, B. S. Secretary to the Director

IX CHARGE OF CO-OPERATIVE IXVESTIGATIONS WTTH C. S. DEPARTMENT OF AGRICLLTLRE

L. M. WINSOR, B. S.

Irrigation Engineer 
Table of Contents.

\section{2}

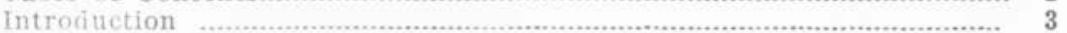

Metuing of Type of Farming ................................................................ 3

The Ideal Type of Farming.............................................................. 3

Competition of Types of Farming......................................................... 3

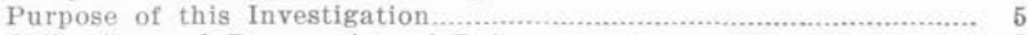

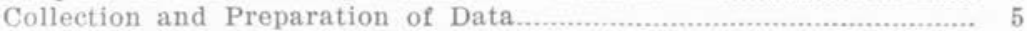

Iyde Park, Cache County, Utah.................................................................. 6

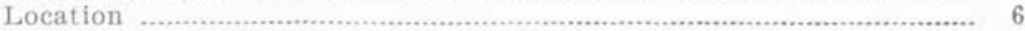

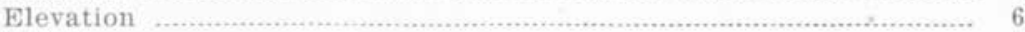

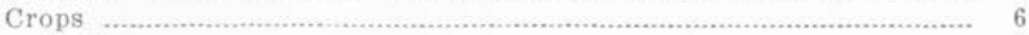

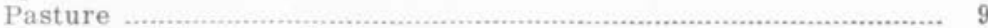

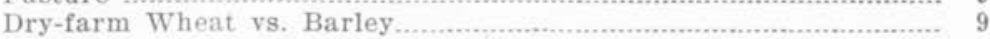

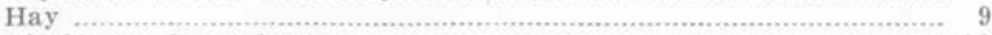

Alfalfa vs. Sugar-beets................................................................ 10

Oats vs. Spring Wheat ........................................................................ 10

Sugar-beets vs. Potatoes....................................................................... 10

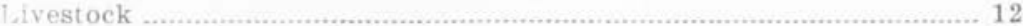

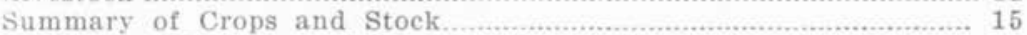

Diversity and Balance of Farm Business........................................... 15

Size of Farm Business........................................................................... 17

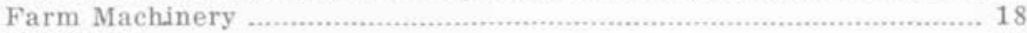

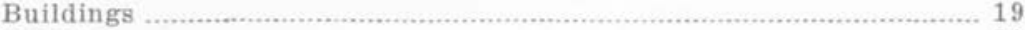

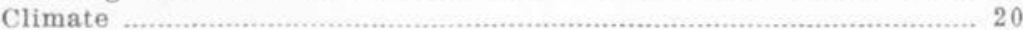

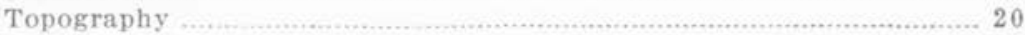

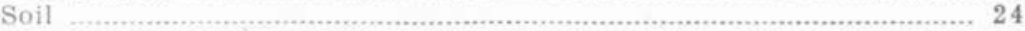

National Forests and Public Stock Ranges............................................ 25

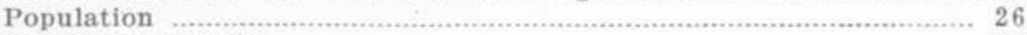

The Farm Family ................................................................................ 29

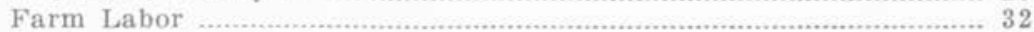

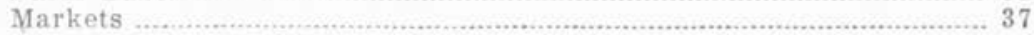

Wagon and Auto Roads and Railroads............................................... 38

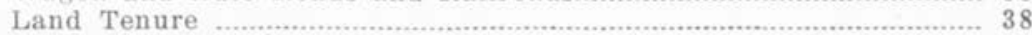

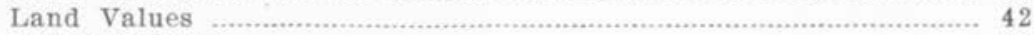

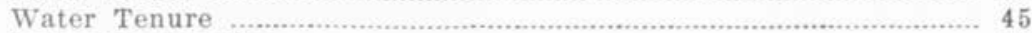

Irrigation Practice …............................................................................. 49

Quantity of Irrigation Water to Use.............................................. 50

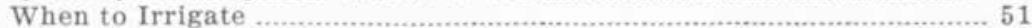

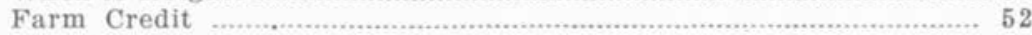

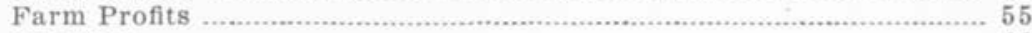

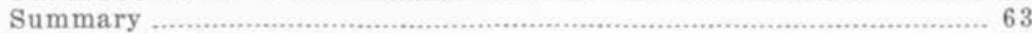

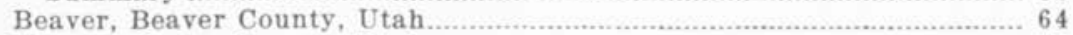

Monroe, Sevier County, Utah . . .

Sandy, Salt Lake County, Utah....................................................................... 70

Ferron, Emery County, Utah...................................................................... 73

Wellington, Carbon County, Utah....................................................... 75

Hinckley, Millard County, Utah............................................................... 76

Pleasant Grove, Utah County, Utah............................................................ 78

General Summary ...................................................................................... 81

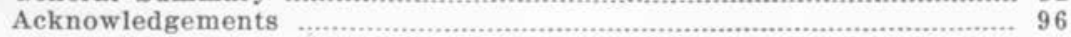

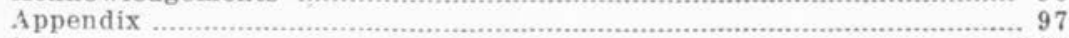

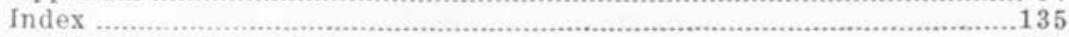

Illustrations in Text.................................................................................135

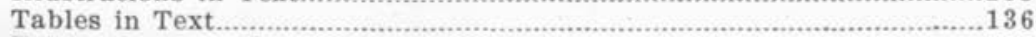

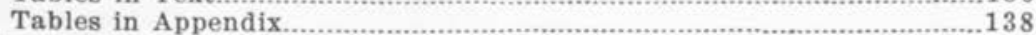

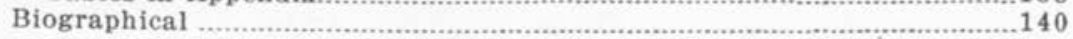




\section{ERRATA}

Page 16, Table VII, "Receipts" from "Ifvestack" should be $\$ 7 \$ 2$ in. stead of $\$ 798$.

Page 55, Table XXXVI, "Expenses" should be $\$ \$ 82$ instead of $\$ 1,882$,

Page 57, Table XXXVIII, under "Farm Capital", "Machinery" value should be $\$ 531$ instead of $\$ 542$.

Page 58, Table XxxIX, Miscellaneous receipts on the 10 betterpaying farms should be $\$ 314$ instead of $\$ 413$.

Page 59, Table XL, under "Farm Capital", value of buildings on 10 better-paying farms should be $\$ 1,448$ instead of $\$ 1,14 \$$, the value of livestock on the average of all 32 farms should be $\$ 1,584$ instead of $\$ 1.534$ and the total farm capital on the average of an the 10 better-paybe $\$ 12,057$ instead of $\$ 12,056$. The farm income on the income should ing $\$ 12,057$ instead of be $\$ 1,730$ instead of $\$ 1,760$.

Page 98, Table II, "Crop Actes Ter Man". on the 10 better-paying farms should be 42 instead of 14 . 


\title{
SOMF TYPES OF IRRIGATION FARMING IN UTAH( $\left.{ }^{1}\right)$
}

\author{
By
}

\author{
E. B. BROSSARD
}

Meaning of Type of Farming.-As ordinarily used "type of farming" suggests general contrasts in the nature of farm business. The bases used in making these contrasts are: (1) sources of farm income, (2) number of farm enterprises, (3) amount of labor, capital, and management applied to each acre of land, and (4) farm practice with reference to maintenance of soil fertility. When based on sources of farm income, farms àre classified as grain farms, hay farms, fruit farms, dairy farms, etc., according to the proportionate magnitude of the income from the different sources. When the number of farm enterprises is used as the basis, farms are classified as specialized or diversified. When the amount of labor, capital, and management applied to the acre oi land is used as the basis, farming is said to be either extensive or intensive. When the farm practice of fertility maintenance is used as the basis of comparison, farming is either exploitive or conservative. These contrasts, tho arbitrary and general, are valuable in suggesting the extremes of farming types. In this study, not only the extremes are noted, but some small differences and similarities in the combination and inter-relations of the farm enterprises are pointed out. Amounts and kinds of crops and livestock raised, purchased, and sold are important as are also the amounts and combinations of machinery, buildings, land, water, labor, and management. Therefore, "type of farming", as used here means kind of farming, and in order to describe the kinds of farming practised in these areas in Utah, more detail is given than is ordinarily suggested by the phrase "type of farming."

The Ideal Type of Farming. - The ideal type of farming for any community at any one time is that which combines crops, livestock, machinery, buildings, land, water, labor, and management of such kinds and grades, and in such amounts, numbers and proportions, and in such ways as to yield the highest longtime average net returns for each unit of management or for each manager.

It is perfectly obvious that the farmer is not an independent, isolated individual, but a cooperating member of society. The farmer's business is not an independent one, but in these days of commercial agriculture, is dependent to a great extent upon the nation and society. Each farmer is a member of the present system of "Individual Exchange-Cooperation" (2) and all of the cooperating parties are entitled to consideration as factors in determining the ideal type of farming. There are cases where the immediate interests of the farmer are not in harmony with the best interests of the nation and society generally.

The fact that the farmer is a member of our competitive society must not be overlooked. The farmer desires to obtain as much for his wages of labor, wages of management, and pay for risk or responsibility taken, as he can get legitimately. In other words the farmer wishes the largest profits possible. In so far as the acts of the individual farmer, in seeking the largest possible profits from his enterprises, are in harmony with the best interests of the nation and society generally, it is to the advantage of the nation and society to permit him to attain his ambition.

Competition of Types of Farming.- Since so many conflicting factors contribute to the establishment of farming practice that no one

(1) Presented as a thesis in partial fulfillment of the requirements for the doctors degree (Ph. D.) at the University of Minnesota.

(2)Taylor, F. M., and Adams, E. C., Prin. of Econ. (1918), p. 12, Fifth Ed., Ann Arbor, Mich. 
can hope to give proper consideration to all of them, it is impossible to tell the best type of farming for a given region without its being tried. In this study only the most conspicuous factors are considered. The effects of individual factors and sets of factors are different in different districts. The effects of similar factors often vary even for two adjoining farms.

It is likely that the types of farming practised in the areas investigated are, in general, the best since they are the results of fifty or more years of experience of the farmers of these areas. A half century ago these farmers, or their predecessors, obtained certain definite lands with given natural and economic conditions. As a result of their combined experiences, with the various crop and livestock enterprises, they were. in 1914,1915 , and 1916, following the practices described in this thesis.

Perhaps the chief factors in determining the type of farming in any region are the natural factors such as (1) climate, (2) soil, and '(3) topography; but the economic factors of (1) demand, (2) supply, and (3) transportation, often established a type of farming in a community in spite of natural advantages and disadvantages.

The usual condition is not a given farmer seeking a certain sort of farm, but a particular farmer on a given farm desiring to know the proper type of farming. The important thing, therefore, is to learn of as many factors as possible, - if not of all the factors, - that influence particular types in individual areas, and to analyze their effects.

The fact that the elements that determine type are subject to frequent change makes the proper balancing of them difficult. The successful farmer must be keen, alert, progressive and use good business judgment if he is to keep. up-to-date in his type of farming. New things are constantly being tried by one or more farmers. They should be generally adopted only when it is reasonably sure that their adoption will make the farm enterprise as a unit pay better than it does with present practices. Nothing but experience can prove a type of farming best for a given farmer and a given farm, and even after a successful year with a given type, a farmer is rarely sure that his type is the best. He frequently wonders if he would not have done better had he followed another type, and no individual will be able to give him a positive answer either in the negative or affirmative, because of the innumerable variables that affect the solution of the problem. But a study of the apparent factors may be suggestive. Because of these frequent changes in the economic conditions of a community, the type of farming must change and accommodate itself to the new conditions. Present practices have evolved slowly. Often ten, twenty, or thirty years go by before the best type is generally adopted by the farmers of a community. Some of the reasons why this is so are as follows: (1) the farm buildings are adjusted to the present type and changes are costly, (2) the machinery may require replacement by that more suitable to the new type, (3) city warehouses may be made useless, (4) credit may be hard to get, (5) markets for the products to be abandoned may be well established causing difficulty in changing to the new type, (6) the farmers and the public may lack knowledge concerning the new type. (7) the difficulty of distinguishing a temporary overproduction from conditions that call for the abandonment of a crop or stock enterprise operates against rapid changes, and (8) the natural conservatism of farmers keeps them from making the changes hurriedly. Types of farmers are often more persistent than types of farming.

It is evident that the best type of farming for a community this year may not be the best a few years from now. It is likely that before the majority of farmers have adopted the first readjustments they find it necessary to begin a second series. Sometimes a type pays so well or so poorly in a community that it is readily adopted or rejected hy a major- 
ity of farmers. More often, however, there are several or many competing types in each community and slight variations in the conditions cause gradual changes in type. It is in the interrelations of all the factors both natural and economic that the type of farming is determined, and as a rule the type practised is not far from what it should be.

Purpose of this Investigation.-Technically trained agriculturists have studied carefully many of the natural or physical factors of agricultural production. Some of the economic factors have also been analyzed and correlated. But not all of the interrelations of these factors and their effects on type of farming are generally understood. It is for the purpose of showing some of these interrelations and their effects on type of farming that this investigation is undertaken.

Collection and Preparation of Data.-Liberal use has been made of publisbed and otherwise available material compiled by others, as is

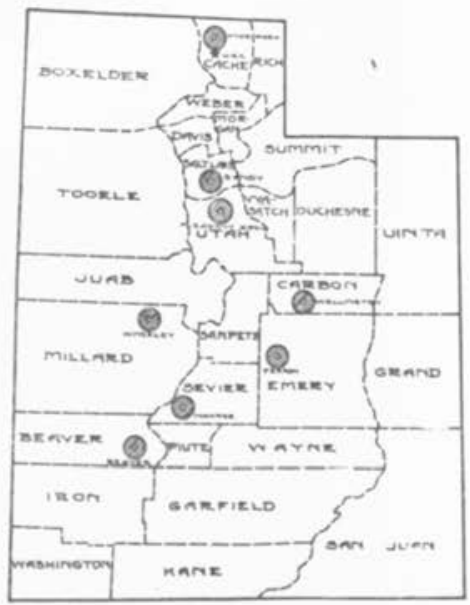

Fig. 1.--Location of the 8 areas investigated, Utah. shown thruout the thesis by the numerous references. The data for the original investigation were collected by the writer and assistants. during the years 1914,1915 , and 1916, while he was in the employ of the United States Department of Agriculture and the Utah Agricultural College. The work was done in cooperation with the County Agricultural Agents and the Farm Bureaus of the respective counties in which the areas are located.

The areas investigated were chosen because they are representative of various types of irrigation-farming and of varied natural and economic conditions in irrigated areas in the Rocky Mountain States. Each area is discussed separately. Averages are usually used as the basis of analysis.

Some farms were dropped from the investigation after 1914 and 1915 respectively and other farms were added to the groups after 1914 and 1915 respectively. Only part of the farms have been cooperating the three years. This does not, however, impair the accuracy of the data for this investigation, since it is not its Furpose to show the evolution of agriculture on the individual farms during this period, but rather the types of farming practised on these irrigated farms and the reasons for such types.

The data presented here have been calculated from records of farm business which were obtained by the Survey Method(1). The smallest number of records obtained at any one place was at Wellington. Carbon County, 1914, where only 26 were taken. The most taken was in the Sandy Area, Salt Lake County, 1914, where 72 were obtained. (See Table I.)

In the following areas, records were obtained for the three consecutive years, 1914,1915 , and 1916 , for the farm business year beginning January 1: (1) Beaver, Beaver County; (2) Hyde Park, Cache County;

(1) Warren, G. F., Cornell University, Buls. No. 295, (March, 1911), No. 334, No. 344, (April, 1914); Spillman, W. J., U. S. D. A., Professional Paper, Bul. No. 529, (April, 1917); Thompson, E. H., U. S. D. A., Farmers' Bul. No. 661, (April, 1915). 
Table I.-Number of Farm Records Studied Each Year by Counties, Utah

\begin{tabular}{l|r|r|r|r|r|r|r|r|r}
\hline \hline Year & Beaver & Cache & Carbon & Emery & Millard & Salt Lake & Sevier & Utah & Total \\
\hline 1914 & 50 & 52 & 26 & 39 & 59 & 72 & 63 & & 361 \\
1915 & 40 & 48 & & 48 & 60 & 47 & 38 & & 281 \\
1916 & 44 & 32 & & 34 & 39 & 45 & 57 & 57 & 308 \\
\hline Total & 134 & 132 & 26 & 121 & 158 & 164 & 158 & 57 & 950 \\
\hline
\end{tabular}

(3) Ferron, Emery County; (4) Hinckley, Millard County; (5) Sandy, Salt Lake County; and (6) Monroe, Sevier County. (See Table II).

Table II.-Number of Farm Records by Length of Record for each County, Utah

\begin{tabular}{l|c|c|c|c|c|c|c|c|}
\hline \hline \multicolumn{7}{c}{ Number of Farm Records } & for Each County \\
Year & Beaver & Cache & Carbon & Emery & Millard & Salt Lake & Sevier & Total \\
\hline 1914 & 50 & 52 & 26 & 39 & 59 & 72 & 63 & 361 \\
$1914 \& 1915$ & 30 & 32 & & 25 & 34 & 48 & 35 & 204 \\
1914,1915 & & & & 25 & 34 & 15 & 35 & 171 \\
and 1916 & 30 & 32 & & 25 & 34 & 15 & 35 \\
\hline
\end{tabular}

For the years 1914 and 1915 , the center of the Sandy Area was Sandy, but in 1916 most of the records were taken at Draper, which is the township south of Sandy. The Wellington, Carbon County records were taken for 1914 only, and the Pleasant Grove, Utah County records were taken for 1916 only.

A study of the type of farming in any area has the five following phases: (1) enumeration and description of the individual crop and stock enterprises, (2) determination of the magnitude and importance of each separate enterprise, (3) determination of the combinations of tue enterprises, (4) determination of the proportions in which the enterprises are combined, and (5) analysis of the factors affecting the choice of the enterprises and their combinations. As far as practicable, in this study, the descriptive part is given first and the analytical part subsequently. The Hyde Park area is treated in detail and the other seven areas only briefly.

\section{HYDE PARK, CACHE COUNTY, UTAH}

Location.-Hyde Park town is in Cache County, in the North Central part of the State of Utah. It is situated on the east side of Cache Valley at the western base of the Bear River Range of mountains. It is five miles north from the center of Logan, which had a population of 7,522 in 1910 (1), and is four miles south from Smithfield, which in 1910 had a population of 1,865 . It is four and one-half miles north from the Utah Agricultural College. ( See Figure 1).

Elevation.-The elevation is about 4,507 feet above mean sea level.

Crops. - Table XXX in the appendix shows the total area of the 32 Hyde Park farms and the use to which each acre was put in 1914,1915 . and 1916 respectively. It thus shows the kind and importance of the crops grown based on the acreage harvested. There has been a slight increase during the three year period in the acreage of winter wheat grown, for two reasons: first, the price of wheat has increased more than the price of the other crops; and, second, dry-farming has been extended to land that formerly has been used only as grazing land. Otherwise the changes in land ownership and operation and in the

(1) 1910 U. S. Census. 


\begin{tabular}{|c|c|c|c|c|c|c|c|c|c|c|c|}
\hline \multirow{2}{*}{ Items } & \multicolumn{3}{|c|}{ Farms Reporting } & \multicolumn{4}{|c|}{ Average Acres(1), 32 Farms } & \multicolumn{4}{|c|}{ Average Acres( ${ }^{(1)}$, Farms Reporting } \\
\hline & 1914 & 1915 & 1916 & 1914 & 1915 & 1916 & $\begin{array}{l}\text { 3-year } \\
\text { Average }\end{array}$ & 1914 & 1915 & 1916 & $\begin{array}{c}\text { 3-year } \\
\text { Average }\end{array}$ \\
\hline Farm Area & 32 & 32 & 32 & 115 & 119 & 119 & 118 & 115 & 119 & 119 & 118 \\
\hline Owned by Operator & 32 & 32 & 32 & 92 & 96 & 93 & 94 & 92 & 96 & 93 & 94 \\
\hline Cash rented land ..... & 11 & 9 & 11 & 17 & 11 & 16 & 15 & 50 & 39 & 45 & 45 \\
\hline Slare rented land... & 3 & 5 & 4 & 6 & 12 & 10 & 9 & 65 & 79 & 81 & 75 \\
\hline Crops & 32 & 32 & 32 & 59 & 57 & 51 & 56 & 59 & 57 & 51 & 56 \\
\hline Pasture ......... & 28 & 30 & $\ldots .$. & 41 & 39 & $\ldots$. & $40(2)$ & 47 & 42 & $\ldots . .$. & $44(2)$ \\
\hline Summer fallow........... & 8 & 7 & & 13 & 17 & $\ldots .$. & $15(2)$ & 52 & 78 & $\ldots .$. & $65(2)$ \\
\hline Farmstead and waste & 32 & 32 & & 3 & 6 & $\cdots$ & $4(2)$ & 3 & 6 & $\cdots$ & $4(2)$ \\
\hline Dry-farm land. & 10 & 10 & 12 & 34 & 37 & $\ldots$ & $36(2)$ & 109 & 118 & .... & $114(2)$ \\
\hline Winter wheat... & 10 & 10 & 12 & 16 & 17 & 18 & 17 & 50 & 54 & 48 & 51 \\
\hline Barley & 10 & 7 & 5 & 5 & 3 & 1 & 3 & 17 & 14 & 6 & 12 \\
\hline Summer fallow ......... & 8 & 7 & & 13 & 17 & & $15(2)$ & 52 & 78 & $\ldots$. & $65(2)$ \\
\hline Irrigated crop land. & 32 & 32 & 32 & 38 & 37 & 32 & 36 & 38 & 37 & 32 & 36 \\
\hline Alfalfa & 30 & 27 & 30 & 13 & 12 & 14 & 13 & 14 & 15 & 15 & 15 \\
\hline Timothy and clover & 10 & 13 & 6 & 2 & 4 & 2 & 3 & 8 & 10 & 8 & 9 \\
\hline Wild hay, etc.......... & 7 & 5 & 10 & 4 & 4 & 3 & 4 & 19 & 24 & 8 & 17 \\
\hline Sugar-beets & 29 & 29 & 29 & 10 & 9 & 9 & 9 & 11 & 10 & 10 & 10 \\
\hline Oats & 22 & 24 & 20 & 4 & 3 & 2 & 3 & 5 & 4 & 4 & 4 \\
\hline Spring wheat .......... & 14 & 17 & 14 & 3 & 3 & 2 & 3 & 6 & 5 & 5 & 5 \\
\hline Alfalfa seed ............. & 1 & 1 & 0 & 0 & $\theta$ & 0 & 0 & 12 & 15 & .... & $14(2)$ \\
\hline Potatoes ....... & 27 & 19 & 13 & 1 & 1 & 0 & 1 & 2 & 1 & 1 & 1 \\
\hline
\end{tabular}

(1) Areas are given to the nearest acre. No attempt was made to force the figures to check.

(:) A werage for 1914 and 1915 only. 
acreages of the various crops grown are not marked enough nor regular enough to illustrate anything but a satisfactory and stable condition. No radical changes have taken place in the three-year period of this investigation. It is true that the prices of farm products changed during the period, but the type of farming has not changed greatly. The prices of most of the farm products grown here have increased normally. The respective crop ratios have not changed much.

Table III shows the tenure and use of farm land. The 32 farms have an average area of 118 acres, 94 of which are owned by the operator, 15 cash rented, and 9 share rented. There were 56 acres of crops harvested on the average, 36 of which were irrigated crops and the remaining 20 acres of which were dry-farm crops. The remaining land was used about as follows: 40 acres for pasture, 15 acres for summer fallow, and 4 acres in farmstead, roads, and waste.

The recording of the pasture, summer fallow, and waste land in 1916 was not done satisfactorily and therefore is omitted. Because of this fact the three-year average area does not check, but it is nevertheless sufficiently accurate for the present purpose.

Of the dry-farm land, 17 acres were in winter wheat, 3 acres in barley, and 15 or 16 summer fallowed. The 36 rop acres of irrigated land were cropped as follows: (1) hay, 20 acres divided as follows: alfalfa, 13 acres, timothy and clover, 3 acres, and wild hay and oat hay, 4 acres; (2) sugar-geets, 9 acres; ( 3 ) oats, 3 acres; (4) spring wheat. 3 acres; and (5) potatoes, 1 acre.

That these crops are grown successfully is shown by the average yields as given in Table IV.

Table IV.-Crop Yields on Hyde Park Farms, 1914, 1915, and 1916

\begin{tabular}{|c|c|c|c|c|c|c|c|c|}
\hline \multirow[b]{3}{*}{ Crop } & \multicolumn{8}{|c|}{ Average Acre-Yields } \\
\hline & \multicolumn{3}{|c|}{1914} & \multicolumn{3}{|c|}{1915} & \multicolumn{2}{|c|}{1916} \\
\hline & 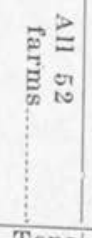 & $\vec{E}^{i v}$ & 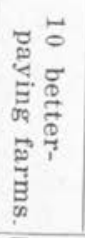 & 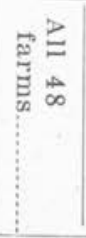 & 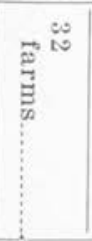 & 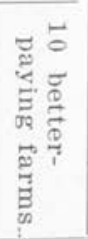 & 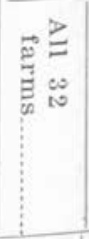 & 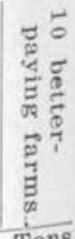 \\
\hline Alfalfa & $\begin{array}{c}\text { Tons } \\
4\end{array}$ & Tons & Tons & Tons & Tons & Tons & Tons & \\
\hline Other Hay... & $\begin{array}{l}4 \\
2.6\end{array}$ & 3.8 & 3.6 & 3.4 & 3.5 & 3.4 & 2.7 & $\begin{array}{l}2.9 \\
1.8\end{array}$ \\
\hline Sugar-beets . & $\begin{array}{r}2.6 \\
18.6\end{array}$ & 2.4 & 2.4 & 2.2 & 2.2 & 2.8 & 2.0 & $\begin{array}{r}1.8 \\
15.6\end{array}$ \\
\hline Oats & $\mathrm{Bu}$. & $\begin{array}{c}18.6 \\
\mathrm{Bu} .\end{array}$ & 18.6 & 16.5 & 16.6 & 18.0 & 15.2 & $\begin{array}{c}15.6 \\
\mathrm{Bu} .\end{array}$ \\
\hline Irrigated Wheat... & 70 & $\begin{array}{r}\text { Bu. } \\
69\end{array}$ & Bu. & Bu. & $\begin{array}{c}\text { Bu. } \\
64\end{array}$ & $\begin{array}{r}\text { Bu. } \\
63\end{array}$ & $\begin{aligned} \text { Bu. } \\
58\end{aligned}$ & 83 \\
\hline Dry-farm Wheat.... & 31 & 32 & 241 & 36 & $\begin{array}{l}64 \\
44\end{array}$ & $\begin{array}{l}03 \\
36\end{array}$ & 34 & 32 \\
\hline Dry-farm Barley... & 271 & 24 & $24^{1}$ & 21 & 21 & 19 & 18 & 20 \\
\hline Irrigated Barley.......... & 281 & $24^{1}$ & 231 & 11 & $13^{1}$ & 8 & $25^{1}$ & $26^{1}$ \\
\hline Potatoes & $\begin{array}{r}281 \\
178\end{array}$ & 241 & 231 & 41 & $13^{1} \mid$ & 60 & $25^{1}$ & $26^{1}$ \\
\hline & 178 & 188 & 205 & 56 & 52 & 36 & 172 & 160 \\
\hline
\end{tabular}

The low yield of potatoes in 1915 was due largely to the plant diseases, Fusarium Wilt and Rhizoctonia. All yields except that for spring wheat were lower in 1915 than in 1914 . The yields for all crops except

(1) Includes that grown on both the dry-farm and irrigated land. 
oats and barley were lower in 1916 than in either 1915 or 1914 . This was due mainly to less favorable climatíc conditions(1) and to plant diseases. However, the yields in 1916 are good compared with the average for the State and the country as a whole.

The average yield of hay, potatoes, corn, winter wheat, spring wheat, oats, and barley in Utah is 184 per cent of the average yield of the United States and is 174 per cent of the average yield of the State of lowa. (See Tables XXXVIII, XXXIX and XL in Appendix.)

Pasture.-Table III shows that there are about 40 acres of pasture per farm. Almost all of this is permanent pasture. Most of it is on the wet clay-land west of the State road. The greater part of this land west of the State road is used for pasture or meadow. Whether it is pastured or cut for hay is largely a question of need of hay or pasture. Some of this land is cut for hay some years and pastured others. However, much of the land pastured cannot be cut for hay at all until it is drained. It would not pay to cut for hay some of the higher ground in the fields, unless they were leveled and irrigated, as the yield of hay would be too low. Usually, therefore, this land is either in permanent pasture or permanent meadow depending on the soil, topography, possibilities of irrigation, and need of either hay or pasture, on the particular farm. It would not pay to cultivate this land in its present condition.

Some of the permanent pasture land is on the foot-hills and mountains. This land has no other use to which it might be put. If it was not pastured or grazed it would have no agricultural value at all.

Some of the dry-stock of the dairy herds and most of the meat cattle are grazed on the Cache National Forest. This reduces the number of acres of farm pasture necessary to furnish summer feed for stock.

It is largely on account of these pasture conditions at Hyde Park that the dairy industry has developed to its present importance and that the sales of cattle amount to as much as they do.

Dry-farm Wheat vs. Barley.-Two important questions concerning dryfarm wheat and barley are: (1) Why are wheat and barley grown on the dry-farm lands? and, (2) Why does each have its present importance? The answers involve a number of factors, some of which are as follows: (1) wheat and barley are grown because they are the two most successful dry-farm crops (2), (2) wheat is grown as a cash crop, (3) the yields are usually slightly greater for wheat than for barley(3), (4) the price is generally considerably higher for wheat than for barley(4), (5) the cost of production is practically the same for wheat as for barley (5), and (6) barley is more difficult and disagreeable to handle.

The question then arises as to why any barley at all is grown. Why is not all the land planted to wheat? There are three good reasons for planting some barley. (1) Barley is used as feed. (2) A better distribution of labor is obtained by growing both barley and wheat than by growing only wheat. When the feed or labor situation dictates the planting of barley or some less profitable crop or no crop, barley is chosen. (3) Alternate cropping of wheat and barley may increase the yield, as barley is a more shallow rooted crop than wheat.

Hay.-Table III shows that on the 32 farms an average of about 20 acres of hay are grown, of which 13 acres are alfalfa, 3 acres are timothy

(1) U. S. D. A., Weather Bureau Reports.

(2) Widtsoe, J. A., Dry Farming-Text, (1911) pp. 234-243, MeMillan Company,

(3) See Table IV. Crop Yields on Hyde Park Farms, 1914, 1915, and 1916.

(4) See Table XXIX. Farm Prices of some Utah Farm Products, Appendix. $27-29$

(5) Peck, F. W., Minn. Agr. Exp. Sta. Bul. No. 179, (Nov. 1918), pp. 
snd timothy and clover, and 4 acres are wild hay and oat hay. Oat hay is cut only in emergencies and the amount is negligible. Wild hay is grown on land that at present is too low and wet for cultivation. Some of it is wet naturally, but some is made too wet for cultivation by irrigation of the higher land nearer the mountains. The timothy and timothy and clover are grown largely for horse feed. As a rule it is grown on land that would grow alfalfa but occasionally timothy and clover seed are sovn on land that is slightly too wet for alfalfa. Some timothy and clover is also raised in crop rotation instead of alfalfa because sugar-beets are more casily handled on this than on alfalfa sod.

Alfalfa is the main hay crop and constitutes about 65 per cent of the total hay acreage. On suitable land so situated as to be irrigable, alfalfa has no near rival when grown for feed for dairy cows or other cattle. Its feeding value and its high yields make it king of the irrigated feed crops.

But now the question arises as to why these farmers grow on the average $13-15$ acres of alfalfa and 9 or 10 acres of sugar-beets when much of the land that grows alfalfa might be planted to sugar-beets or vice versa.

Alfalfa vs. Sugar-beets.-Sugar-beets are usually grown on the best piece of land on the farm. From 4 to 6 times as much labor is put on each acre of sugar-beets as on an acre of alfalfa. For this reason it would be unwise to plant beets on inferior land. The reasons why 10 acres of heets are grown are given later. But why grow 13 to 15 acres of alfalfa? The farm family wants to make as much as possible out of the farm. To grow alfalfa for livestock that may be pastured in summer, and fed in winter, with a fairly good market for dairy products existing, gives a better labor distribution, makes it possible to do some productive work in winter, and saves paying out an excessive amount for wages for hired help in summer, and therefore nets a greater income, than planting sugarbeets on all of the good arable irrigated land. The present acreage of alfalfa is sufficient, when the other hay is added to it, to feed the stock inventoried and in normal years a small surplus is sold. In abnormally poor hay years, or years when excessive amounts of feed are required, the hay is all fed in the distriet.

Oats vs. Sipring Wheat.-Table III shows that on the average 3 to 4 acres of oats and 3 to 5 acres of spring wheat are grown on the farms at. Hyde Park. These crops are non-competing. Growing both gives a better distribution of labor than growing either one to the exclusion of the other. Oats are grown mainly for horse feed. Four acres at 65 bushels to the acre gives a total yield of 260 bushels for an average of 4 work horses or 65 bushelz of oats each year for each horse. Not all of these oats are fed to horses, however, as some are also fed to cows in the district, and a few are shipped out of the district.

The spring wheat is grown as a cash crop on irrigated land. It is sometimes alternated with cats and sometimes it is seeded on alfalfa sod the year before sugar-beets are planted. Alternating wheat and oats gives greater yields; and the planting of wheat on alfalfa sod allows the alfalfa roots and crowns to largely decompose, which facilitates beet culture the following year.

Sugar-beets vs. Potatoes. - Sugar-beets and potatoes are crops that compete for capital, labor, management, and irrigated land. The question arises as to why they are grown in the present proportions. Why is it, that on the farms reporting these two crops, 9 to 10 acres of sugar-beets and less than 1 acre of potatoes are grown? The answer divides naturally into several parts. The 10 to 11 acres of sugar-beets and potatoes are grown instead of more acres of these crops largely because the farm family is the basic unit, around which the farm business is organized, and 10 or 11 acres of these comparatively intensive crops are about all that the average farm family can handle without hiring excessive amounts of 
labor during rush seasons. Some of the reasons why 9 or 10 acres are hevoted to sugar-beets and only 1 or less to potatoes are brought out in the following pages.

Table $\mathrm{V}$ shows that the average acre-value of . sugar-beets for the hree years, 1914,1915 , and 1916 , was $\$ 79$, and for potatoes $\$ 77$, or but $\$ 2$ higher for sugar-beets than for potatoes, or 3 per cent of the average acre-value of potatoes grown.

Table V.-Yieid, Price, and Acre-Value of Sugar-beets and Potatoes, 1914, 1915, and 1916, Hyde Park, Cache County, Utah

\begin{tabular}{|c|c|c|c|c|c|c|c|}
\hline \multirow{3}{*}{ Year } & \multirow{3}{*}{$\begin{array}{c}\text { No. } \\
\text { Farns } \\
\text { Report. } \\
\text { ing }\end{array}$} & \multicolumn{4}{|c|}{ Average } & \multirow{2}{*}{\multicolumn{2}{|c|}{$\begin{array}{c}\text { Average Acre- } \\
\text { Value of Total } \\
\text { Product }\end{array}$}} \\
\hline & & \multicolumn{2}{|c|}{ Acre-Yield } & \multicolumn{2}{|c|}{ Unit-Price } & & \\
\hline & & $\begin{array}{l}\text { Sugar- } \\
\text { beets }\end{array}$ & $\begin{array}{l}\text { Pota- } \\
\text { toes }\end{array}$ & $\begin{array}{c}\text { Sugar- } \\
\text { beets }\end{array}$ & $\begin{array}{l}\text { Pota- } \\
\text { toes }\end{array}$ & $\begin{array}{c}\text { Sugar- } \\
\text { beets }\end{array}$ & $\begin{array}{c}\text { Pota- } \\
\text { toes }\end{array}$ \\
\hline $\begin{array}{l}1914 \ldots \\
1915 \ldots \\
1916 \ldots\end{array}$ & $\begin{array}{l}52 \\
48 \\
32\end{array}$ & $\begin{array}{ll}18.6 & \mathrm{~T} \\
16.5 & \mathrm{~T} \\
15.2 & \mathrm{~T} .\end{array}$ & $\begin{array}{rl}178 & \mathrm{Bu} \\
56 & \mathrm{Bu} \\
172 & \mathrm{Bu}\end{array}$ & $\begin{array}{r}\$ 4.50 \\
4.75 \\
5.50\end{array}$ & $\begin{array}{l}.43 \\
.50 \\
.74\end{array}$ & $\begin{array}{r}\$ 84 \\
78 \\
74\end{array}$ & $\begin{array}{r}\$ 77 \\
28 \\
127\end{array}$ \\
\hline Average & for the & three yes & rs .......... & $\ldots \ldots \ldots$ & & $\$ 79$ & $\$ 77$ \\
\hline
\end{tabular}

Some of the potatoes were stored and sold in the spring while all of the sugar-beets were marketed directly from the fields in the fall.

In 1914 the average acre-yield of potatoes was 178 bushels. The average price of those sold was 43 cents a bushel. The total value of the product of an acre was, therefore, $\$ 77$. The average acre-yield of sugar-beets was 18.6 tons. The average price received for a ton was $\$ 4.50$. Thus the acre-value of the product was $\$ \$ 4$ or $\$ 7$ more than for potatoes.

Seed potatoes cost about $\$ 5$ to $\$ 8$ an acre, or $\$ 3$ to $\$ 5$ more for each acre than sugar-beet seed, which cost $\$ 2.25$ an acre in 1914 . In areas comewhat similar to the Hyde Park district, the total cost of producing a ton of beets in 1914 and 1915 , where the acre-yield was 16 tons or over, varied from $\$ 3.93$ to $\$ 4.12(1)$. The net returns, including tops, varied from $\$ 6.85$ to $\$ 9.23$ an acre(1).

The total water requirements for the two crops are about the same, but the best times for applications differ. The irrigating of sugar-beets is not such a precise task as irrigating potatoes.

The labor requirements for potatoes are about 114 man hours and 115 horse hours an acre annually (2). The labor requirements for sugar-beets are about 143 man hours and 142 horse hours an acre annually (2) (3). Sugar-beets require about 26 per cent more man labor and 23 per cent more horse labor than potatoes. From 54.4 to 56.3 per cent of the total cost of producing sugar-beets is labor $\operatorname{cost}(8)$. The harvesting of beets requires about the same amount of labor as harvesting potatoes and both crops are harvested at about the same time of the vear. The labor in the other periods is also competitive but more labor is required each period for sugar-beets than for potatoes.

(1) Moorhouse, L. A., and others, U. S. D. A. Bul. No. 693, (July, $1918)$, p. 41.

(2) Connor, L. G., Utah Agr. Exp. Sta. Bul. No. 165, (Oct., 1918), Tables 15 and 6 , p. 20 .

(3) Moorhouse, L. A., and others, U. S. D. A. Farm Mgt. Bul. No. 693. (July, 1918), p. 42, gives the annual labor requirements for an a ere of sugar-beets as from 119.4 to 133.3 man hours and 79.3 to 117.14 horse hours. 
The $\$ 2$ excess ine acre-value of product of sugar-beets over potatoes is only $6-2 / 3$ cents an hour for the 30 additional man hours required to produce each acre of beets.

These facts seem to indicate that if all labor was hired the potato crop would be much more popular in comparison with sugar-beets. The great amount of unpaid family labor at Hyde Park makes it more profitable to raise sugar-beets than potatoes because in raising beets the annual net returns for this labor is slightly greater. This indicates that the farm family is the basic unit of production and not alone the farmer or head of the family.

The rather heavy compact soil at Hyde Park is generally better adapted to sugar-beet tnan potato culture.

Another reason why sugar-beets are grown instead of potatoes is that there is but a limited local market for potatoes. The products must compete in distant markets. Beets are manufactured into sugar. This final product is a much more concentrated (less bulky) product than potatoes and ean thus compete more favorably in distant markets than can potatoes. This fact has made it possible for the sugar manufacturers to pay a price for beets sufficient to induce farmers to grow them instead of growing potatoes.

The factories do not necessarily have to pay sufficiently high prices for the beets to make growing them as profitable to the farmer as the potato crop, because by their method of contracting for the beets they relieve the farmers of the risk of loss from low prices. Before the farmer plants his sugar-beet seed he knows what price he will get for each ton of his product marketed in the fall. The farmers contract with the sugar companies to raise a certain acreage of beets, and for each ton marketed in the fall they receive a contract price. This almost assures the farmer a profit from raising beets unless the year is so abnormal as to cause a crop faflure. In raising potatoes the farmer takes the risk of low prices as well as that of crop failure. The sugar manufacturing companies have had the advantage of all increase in the price of sugar and have borne the risk of a decreased price. These companies, however, are more able to take this risk in speculating than the farmers and the majority of farmers are glad to have them do it, as farming is thus made more stable. Consequently farmers are usually willing to allow the sugar companies a reasonable remuneration for this service.

The question that now naturally arises is: why are there any potatoes at all grown here. The main reason is that they are grown for home use and it is good business to grow them for this purpose even tho they are not as profitable a commercial crop as sugar-beets. When a very good crop of potatoes is raised there are more than enough for family use and some are sold, but usually this surplus is small. The growing of commercial potatoes in this district is sporadic. After a good potato year a few farmers are tempted to plant potatoes as a commercial crop. A few farmers plant them after alfalfa and before sugarbeets in the crop rotation because of the difficulty of growing sugarbeets following alfalfa on account of the undecayed alfalfa roots and crowns,

Livestock.-Table VI shows the average number of livestock units(1) on the Hyde Park farms cooperating in this investigation. The units for 1916 are not calculated as the two-year average is sufficient for the purposes of this paper.

There were 12 per cent more animal units on farms at Hyde Park

(1) An animal unit is 1 cow, 1 bull, 1 grown steer, 2 young stock, 1 horse, 2 colts, 7 sheep, 14 lambs, 5 hogs, 10 pigs, or 100 poultry. The basis for such classification is the amount of feed required and manure produced. 
in 1915 than in 1914 . There were fewer work horses and more productive animal units(1) on the farms. There was an increase on the average of 0.7 units of milk cows, 1.6 units of other cattle, and 0.2 units of other horses. There was 0.1 unit fewer hogs, but the same number of poultry in 1915 as in 1914.

Of the 52 farms investigated in 1914,1 had no milk cows, 1 had 1 cow, 6 had 2 each, 14 had less than 5 each, 7 had 10 each, 8 had more than 10 each, 2 had 20 each, and 1 had 24 milk cows. The one farm that had a man hired by the year was one of the two farms that had 20 milk cows. All of the milking and other work on livestock on the other farm with 20 cows and also on the farm with 24 cows was done by the respectie farmers and their families with extra help hired during rush crop-seasons. On the average there were 7.4 units of milk cows on the 32 farms which have cooperated for the three years. The most promising heifers are raised to replace the cows in the dairy herd and usually a few more are raised than are kept on the home farm as cows.

In 1914 the net livestock receipts(2) for each $\$ 100$ worth of feed fed were $\$ 107$ on the 52 farms and $\$ 120$ on the 10 better-paying farms. the net livestock receipts for each productive animal unit were $\$ 60$ on all 52 farms and $\$ 60$ also on the 10 better-paying farms. The net cattle receipts for each head kept were $\$ 22$ on the average of the 52 farms and $\$ 22$ also on the average of the 10 better-paying farms. The milk receipts for each cow were $\$ 56$ on the average of all farms and $\$ 62$ on the average of the 10 better-paying farms.

In 1915 the net livestock receipts for each $\$ 100$ worth of feed fed were on the average of all 48 farms, \$97, of the 10 least-profitable larms, \$52, and of the 10 better-paying farms, \$133. The net livestock receipts for each productive animal unit were $\$ 25$ on the average of all $4 \$$ farms, $\$ 24$ on the 10 least-profitable farms, and $\$ 57$ on the 10 betterpaying farms. (See Tables $I$ and II in Appendix).

Why do Hyde Park farmers on the average keep from 7 to 10 milk cows and why does the number of head vary from none to 24 on the individual farms? In general, the available pasture determines the

Table VI.-Average number of Units of Livestock on Farms, Hyde Park, Cache County, Utah, 1914 and 1915

\begin{tabular}{l|r|r|r|r|r}
\hline \multirow{2}{*}{ Kind of } & \multicolumn{5}{|c|}{ Average Number of Units of Livestock } \\
on Farms \\
Livestock
\end{tabular}

(1) "Productive animal units" includes all livestock except work stock.

(2) The net livestock receipts are found by subtracting the sum of the purchases and what is on hand at the beginning of the year from tne sum of the sales and that on hand at the close of the year.

(a) Includes dry dairy-stock and beef cattle.

(4) Includes colts, ponies, and stallions. 
amount of livestock kept and there are at present about as many units kept on each farm as the pasture, in its present condition, will support. Counting 7.4 units of milk cows and 2.6 units of young dairy-stock as being pastured on the farms, there are 10 animal units to 40 acres of pasture, or 4 acres to each animal unit pastured. The 40 acres of pasture includes tillable pasture, low wet-land, unirrigated bottomland, and mountain pasture. There are about 2.8 acres of pasture for each productive animal unit. However, some of the meat cattle and dry dairy-stock are grazed on the Cache National Forest. From 1 to 3 acres of irrigated pasture is sufficient for an animal unit, but from 10 to 30 , or an average of about 17 acres(1) of mountain pasture is necessary for each animal unit for the grazing season of 5 to 8 months. That the Cache National Forest is grazed to about its full capacity is shown in the paragraph on the National Forests. From personal inquiries and observations extending over the period of this investigation, the writer is convinced that unless pastures are improved, but slight increases are possible in the number of cattle kept. The farmers know guite generally that it is to their advantage to keep as many as they have pasture for. The hope of the future is therefore in the improvement of the pastures and stock kept.

Another factor which sometimes limits the number of cows kept is the number that can be milked by the average farm family, without hindering too much the work on cash and feed crops. This does not seem to be effective here, as the average farm family at home in 1914 consisted of 6 persons. Without neglecting crop work, education, or social duties, undoubtedly more than 7.4 cows can be milked without the aid of the farm women in doing it.

The variation in the number of cows kept on the individual farms is also due to the available pasture. But it is also a result of the variations in capacity and efficiency of individual farmers and farm families. Personal factors affect individual cases and thus affect the average of the district. These points are further discussed in the paragraphs on Population, The Farm Family, and Farm Labor.

The question arises as to why there are any beef cattle kept at all. Why are not suflicient dairy cows kept to utilize all of the farm pasture and avallable grazing land? As a rule the beef cattle are range cattle. They do well on the range but milk cows give but little milk if turned out on the range each-morning. They have to travel too far to get to the range and when they get there, feed is too scarce to produce much milk. Therefore to utilize the range to best advantage range stock are kept on it. The reason that milk cows are kept instead of all range stock is because the farm pastures and farm labor are more profitably utilized with milk cows than with range stock. It is true that the two farmers who have considerable numbers of range cattle have been making good labor incomes. In fact their farms have been classed among the 10 better-paying farms each of the three years. But they have permits to graze their cattle on the Cache National Forest and the other farmers cannot get such a permit readily and find it necessary therefore to keep dairy cows. This point is further discussed in a later paragraph.

Colts are raised both for work and for sale. Hyde Park has somewhat of a reputation among farmers of Cache County for the grade Percheron horses raised there. Horse buyers from Los Angeles and elsewhere recognize that at Hyde Park good, sound work horses can be bought. The farmers take-pride in good colts. Purebred stallions are maintained in the district. They are usually owned cooperatively.

In 1914 on the average of all 52 farms there was 1 work horse to each 14 acres of crops. The same ratio existed in 1915 . The ratios on the

(1) Barnes, W. C., and Jardine, J. T., U. S. D. A., Offlce of Sec., Rep. No. 110 (July, 1916), p. 87. 
averages of the 10 better-paying farms in 1914 and 1915 respectively were 1 horse to 19 acres of erops and 1 horse to 15 acres of crops. (See Tables I and 11 in Appendix).

Farms that have milk cows that are driven down and up the "Cow Lane" to and from the pastures, usually have ponies for the children to ride in making this trip.

Oniy 5 farms have any sheep, 1 has but one sheep, 1 has 2,1 has 10 , 1 has 14 , and 1 has 19 sheep, making in all a total of 46 sheep including lambs. These few sheep are kept as scavengers. They clean out the weeds along the irrigating ditches and fences and clean up around the farmstead.

Hogs are raised mainly for home use. Most of them are bought as pigs, raised, and then butchered. A few farmers keep 1 to 4 brood sows and sell the pigs as little pigs, except enough for their own table use. One reason why more hogs are not kept is because all the farm homes and buildings are in town on town lots. A herd of hogs would be very undesirable under these conditions.

Hens are kept mainly to supply the farm family with eggs and meat. Tbe surplus eggs are sold at the town store. Unless poultry is fenced in, it may be a nufsance to neighbors where houses are close together, gardens not protected with ehicken wire, and the garage door not always closed. Only 5 farms report having 100 hens or more, 2 of these have just 100 each, 1 has 130 , and 2 have 200 each. All of these farm homes are out of the town proper, except 1 and that one is on the northeast corner of a block and no other house is within a block of it.

The hogs and hens are fed largely on table scraps, grain screenings, skim milk, and other waste-feeds. Bran and shorts are sometimes fed to hogs for a short period before killing. The bran is obtained from grists. The wheat is taken to the mill and flour and bran brought back.

Summary of Crops and Livestock. - The details of crop and livestock conditions at Hyde Park have been given in the previous paragraphs. There are three general outstanding features, however, of which special mention should be made. The first distinctive thing to note is that most of the farm land is irrigated and most of the farmers raise sugar-beets on a part of this irrigated land and milk a few cows. But the irrigable land and irrigation water are limited. Suitable pasture for milk cows is also limited. To extend the individual farm business by buying irrigated land means to leave some one else less irrigated land to operate. The game is true with pasture. Therefore to extend the individual farm business in cither of these two directions means to eliminate to that extent the competition of one's neighbors. The second distinctive factor is the dry-farming practised by a few of the farmers. And one should note that there is only a limited amount of dry-farm land and this has already been utilizer by farmers desiring to extend their farm business rather than by new men specializing in dry-farming. The third feature which deserves special mention in this summary is the range cattle business. There are only a fow men who run range cattle on the Cache National Forest. This is because it is so difficult to obtain grazing permits, as the range is stocked to its present capacity. These three features are important. They are found in varying combinations in many districts of the intermountain region. But they are not found in any other section of the country combined in exactly these same proportions.

Diversity and Balance of Farm Business.- Why do farmers raise sugar-beets and wheat instead of raising more pasture, barley, oats, and alfalfa as feed for livestock? While sufficient data to prove the point is lacking the obvious answer to the question is that livestock enterprises are not sufficiently profitable to cause the farmers to give up growing these cash crops for the other practice. On the average the combination is more profitable than the specialization. Raising cash crops utilizes the 
available summer labor to good advantage. The sugar-beet crop, especially, makes labor for school children. The combination of livestock and these cash crops makes a more diversified and better balanced farm business and therefore a safer and more desirable business for the average former than the specialized livestock farming.

In 1914 the average number of different crops grown on the 52 farms was 4.6. There were 3 sources of income the receipts from each of which amounted to at least 8 per cent of the gross farm receipts. These three were sugar-beets, $\$ 705 ;$ milk and its products, $\$ 400 ;$ and grain, $\$ 302$. The average. incomes from other sources were hay, $\$ 44$; potatoes, $\$ 16$; fruit and vegetables, $\$ 7$; cattle, $\$ 227$; horses, $\$ 87$; other livestock, $\$ 68$; miscellaneous receipts, $\$ 238$; and increase in inventory, due largely to livestock and feed and supplies and improvements, $\$ 416$. (See Tables VII in Text and I in Appendix).

Table VII.-Farm Receipts and Expenses, Average of 52 Farms, Hyde Park, Cache County, Utah, 1914

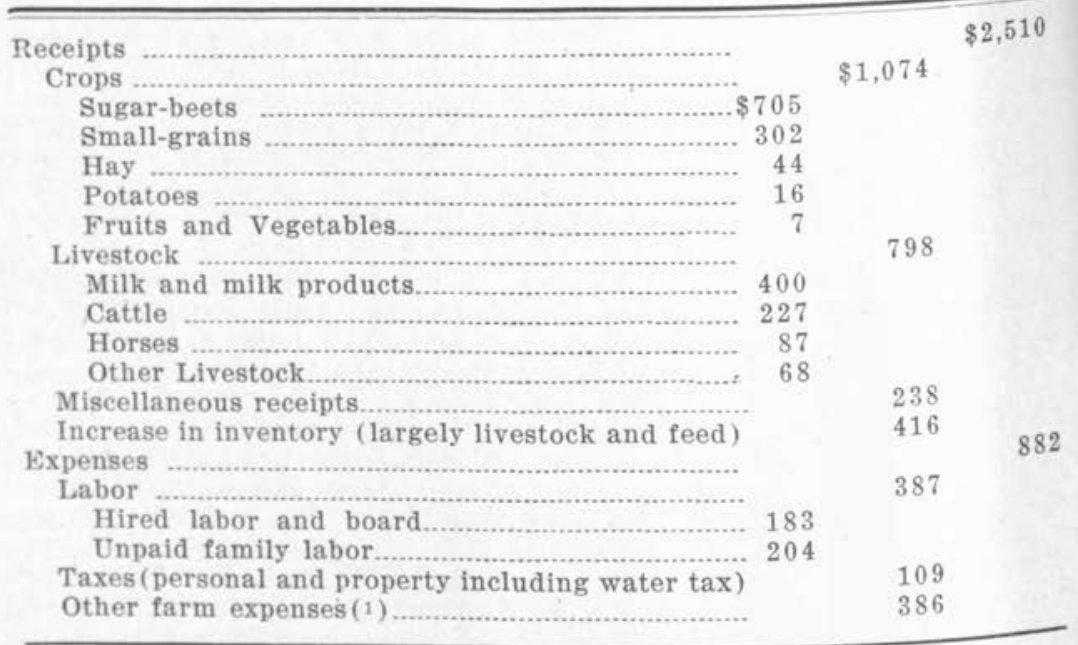

Of the total receipts, $\$ 1,074$ or 43 per cent were from crops, $\$ 798$ or $\$ 2$ per cent from livestock and livestock products, $\$ 400$ or 16 per cent from increase in inventory, and $\$ 238$ or 9 per cent were from miscellaneous sources, the main one of which is outside labor. Of the $\$ 882$ of farm expense, \$387 or 44 per cent was for labor. Excluding taxes the expense for labor including unpaid family labor amounted to 50 per cent of the total expenses.

In 1915 the average of 48 farms shows that 35 per cent of the total farm receipts were from stock and stock products. (See Table II in Appendix).

The 10 better-paying farms grew on the average 5.1 different crops and had 4 sources of income each of which was over 8 per cent of the gross farm receipts. The sources of income were sugar-beets $\$ 1,075$. grain $\$ 891$, milk and its products $\$ 597$, and cattle $\$ 356$. In 1915 on the ?verage of the 10 better-paying farms the receipts from stock and stock products amounted to 38 per cent of the total farm receipts.

(1) Includes building, fence, and machinery purchases, repairs, and depreciation: roughage and concentrates bought for feed; horseshoeing; breeding fees; veterinary bill; medicine; twine; threshing; fees; etc. 
The balance between livestock kept and pasture has been discussed in a former paragraph.

On the average one work horse is kept to each 14 acres of crops but on the 10 better-paying farms there are 19 crop acres to each work horse. There are about 4.4 acres of crops to each productive animal unit on the 10 better-paying farms and only 3.6 crop acres to each productive animal unit on the average of 52 farms. This ratio furnishes ample winter feed for stock and allows growing cash crops as well.

The question arises as to how soil fertility is maintained on these farms. If we assume that each animal unit produces one ton of manure a month we have 234 tons of manure produced $(19.5 \times 12=234)$. If now we assume that half of that is lost to the crop land because the unimals are on pasture for 6 months we have left but 117 tons. Between 30 and 50 per cent of this will be lost in handling. Not more than 60 to 85 tons of manure will be put back on the crop land. Since most of the manure is spread from the wagon box with a fork the applications will be about 15 tons to the acre. At this rate 4 to 6 acres might be covered each year or 20 to 30 acres covered once in a five year rotation. But since the general practice at Hyde Park is to apply the manure to the sugar-beet and potato land and garden, each acre will get an application of about 30 tons every five years, or an average of 6 tons a year. With this practice some of the fields have grown beets each year for 8 to 10 years and the yields are as good if not better than when they began to grow the crop. No other fertilizer is used at Hyde Park.

Size of Farm Business. - There is no measure that is universally used as a standard in determining the size of farm business. When by size, capacity in contrast with efficiency is intended, the most accurate measure is the total cost of operating the farm business. This includes (1) cash paid out, (2) value of unpaid family labor, (3) value of the operator's labor. (4) interest on the capital investment, (5) all depreciation charges, and (6) any decrease in the inventory of feed and supplies(1). This measure of size has not been calculated for these records because in this study other measures serve the purpose better by being more suggestive. For this publication it is not necessary to have size so accurately measured because no attempt is made to determine the most profitable size of farm business. A number of other measures have been used that have considerable significance. In 1914 the average capital investment in the 52 farms was $\$ 13,642$. The average farm receipts were $\$ 2,510$. On the average the farms contained 105 acres. 54 of which were in crops. The average size of farm business in 1915 and 1916 did not differ greatly from that in 1914. (See Tables I and II in Appendix). Where the farm business was not sufficiently large some farmers increased the size by renting additional land as shown in Table III. Undoubtedly other farmers increased the size of the farm husiness unit which they operated by purchasing additional land and livestock. As a rule a farmer who has a small business realizes that he might make more money if his business were larger, but often he is incapable of overcoming all the obstacles to enlarging the business.

Some reasons for small farms here are revealed by the history of settlement. In the fall of $1859 \mathrm{Wm}$. Hyde (after whom the town was named), Simpson M. Molen, and Patterson D. Griffith, left Lehi, Utah County, for Cache County, for the purpose of obtaining farms and making home for their families. They arrived at the present site of Hyde Park, and found there a small creek flowing from the mountains which

(1) Spillman, W. J., U. S. D. A., Farm Management Cir. 1., (Jan. $1916)$, p. 13. 
could be used for irrigating crops and for cullinary purposes. They used their squatters rights and staked out claims. After staking out their claims these three men returned to Lehi for the winter.

The exact number of acres first laid out is not known, but Wm. Hyde, son of the pioneer, estimated that not more than 50 acres were included in each farm as originally staked out. One reason for not taking larger farms was the scarcity of water. The little creek would not irrigate more land than was then included in the three claims. Dry-farming taken from at that time and the possibilities of irrigation water being that with the littl River were not then anticipated. Another reason is, land made a good machinery then in general use, 50 acres of irrigated In the spring family-sized farm.

another party, of which they returned to their claims to find that the same claims that Robert Daines was a member, had squatted on The difficulties which the Lehi party had staked out the fall before. dividing the land betwe over this situation were amicably settled by to 25 acres. This was about parties so that each farmer had from 10 then existing conditions. After the passage of

of obtaining irrigation of the Homestead Act (1862) and the possibilities tracts of 160 acres were from the Logan River were appreciated, remain intact now. Some parents desiring chi of them have been divided and redivided. and began for themselves to remain near home when they married Other farms have been gave a portion of the farm to each child. the children and later leach as estates and consequently divided among

other reasons why each piece sold as a separate entity.

operators to handle a large are not larger are the inability of the physical infirmities, lack or business because of old age, ill health, pendableness of farm labo capital or credit, scarcity of labor, undearound the farm fome. labor, and inconvenience of having hired labor

At present it is come.

separate pieces of land whis for a farm unit to be composed of 5 to 8 other. This situation wastes may be 1 to 3 miles apart from each sity of farm enterprises astes labor but perhaps allowes greater diverfamilies live in town as a partial compensation. The fact that farm labor and reduces the and have the barns and chores in town wastes handicaps a fairly large farm business is done on the average farm at prosperous. (See paragrapheome secured shows that the farmers are appendix). (See paragraph on Farm Profits and Tables I and II in

of modern type and cons machines used on the farms in this area are binders and dry-farm construction. Irrigated grain is cut with selfthreshed by steam threshers. hay loaders, buck rakes, eral use. Most of the alfalfa is, hay forks, hay nets, etc., are in genunloaded at the barn or stack is pitched on the wagon by hand and or corn machinery is used, stack with derrick and fork. No special potato to justify owning it. Most as these crops are not of sufficient importance sulky plows. Some two way the plowing is done with 1 and 2-bottom

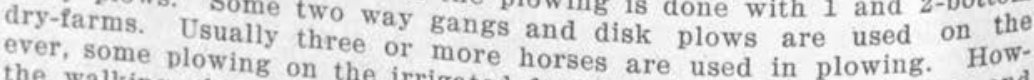
the walking plow. Sugar-beet irated farms is done with two horses and farmers usually pay the sugat seed is drilled in in the spring. The seed and $\$ 0.50$ an acre for seedingufacturing company $\$ 2.25$ an acre for 
Taible VIII. - Average Value of Farm Machinery, Hyde Park Farms, Cache County, Utah, 1914, 1915, and 1916.

\begin{tabular}{|c|c|c|c|c|c|c|}
\hline & \multicolumn{4}{|c|}{ Value per Farm } & \multirow{2}{*}{\multicolumn{2}{|c|}{$\begin{array}{l}\text { Value per } \\
\text { Crop Acre }\end{array}$}} \\
\hline & 3 Year & & & & & \\
\hline & Average & 1914 & 1915 & 1916 & 1914 & 1915 \\
\hline Average of all 52 farms........ & & $\$ 422$ & & & $\$ 7.81$ & \\
\hline Average of all 48 farms......... & & & $\$ 469$ & & & $\$ 9.02$ \\
\hline Average of all 32 farms........ & $\$ 421$ & 407 & 461 & $\$ 395$ & & \\
\hline Average of 10 best farms.... & 479 & 531 & 489 & 416 & 5.06 & 7.76 \\
\hline Average of 10 poorest farms & 408 & 444 & 405 & 374 & & 7.94 \\
\hline
\end{tabular}

The beets are cultivated with 1 and 2 -horse beet cultivators and are plowed out in the fall with beet plows. Table VIII shows that the average value of machinery in this district is about $\$ 420$ to the farm and ranges from $\$ 141$ to $\$ 1,622$ to the farm. There were $\$ 5$ to $\$ 9$ worth of machinery for each acre of crops. The more profitable farms have more machinery on each farm and less for each acre of crops than the average farm.

The average value of farm machinery on each farm in 7 areas in Itah in 1914 was $\$ 449(1)$. The farms with the larger amount of capital have a greater numerical amount but a less proportionate amount of it invested in machinery than do the farms with less capital. The value of machinery for each crop-acre is less and consequently machinery cost for each acre of crops is less on the large farms than on the small farms. The efficiency of farm machinery increases with an increase in the acres of crops (-).

The perfection of machinery causes great changes in the type of farming. As the cotton gin, threshing machine, and steel plow have made great changes possible, so may the perfected sugar-beet thinner and topper when developed.

Buildings. - The type of farming followed and the size of the farm business determine the kind and size of farm buildings required. The farm buildings at Hyde Park consist of dwelling house, cow and horse barn, milk house, small pig-pen, hen house, machine shed, and granary. On a few farms the cow barn is separate from the horse barn. Not all the farms have a milk house. The size of the milk house and cooling trough should be correlated directly with the number of cows milked and the care given the milk. The hen houses and machine sheds are usually very ordinary lumber structures. Since but a few hogs are kept a small hog-pen is all that is necessary. Some fairly large and well built granaries are found, some of which were constructed twentyfive or thirty years ago when wheat was raised on the irrigated land as a cash crop. Some of these are little used now but others are used for the dry-farm wheat, spring wheat, and oats.

It sometimes happens that the farm buildings determine the farm practice on a given farm at a given time. It has happened at Hyde Park, that because of insufficient storage space, grain and potatoes have of necessity been sold in the fall at harvest time when if the storage space had been available they would have been held until winter or spring.

(1) Brossard, E. B., Utah Agr. Exp. Sta. Bul. No. 160, (Sept. 1917), p. 14, Table XI.

(2) Ibid., p. 35. 
The value of the farm dwelling was estimated by the farmers on the basis of selling value as a home. The homes are not on the farms in this district and the two may easily be valued separately. The other buildings were estimated at sale value for the purpose for which they are being used or for any other use for which they are appropriate.

In 1914 only fifty of the fifty-two farms reported dwellings. The average value was $\$ 1,335$. Dividing the total value of all dwellings reported by 52 gives $\$ 1,284$. The average value of dwellings on 309 irrigated Utah farms in seven areas in 1914 was $\$ 1,056(1)$. The average value of other buildings on the 309 farms mentioned above was \$412. On the 309 farms the average value of buildings was $\$ 14$ to each acre of land. The cost of livestock shelter is less on the large farms than on the small farms because of the greater number of livestock units kept. The larger farms have better dwellings and better barns than the smaller farms.

Climate.-The climate of Utah is the most important single factor determining the type of farming. Low precipitation makes a desert out of a strip along the western edge of Utah 50 miles wide and running north and south almost the entire length of the State. Lack of sufficient rainfall in the crop-growing season makes it necessary to irrigate in most parts of the State. Where irrigation water is scarce or unavailable and precipitation amounts to 12 inches or more, with other conditions favorable, dry-farming may be practised. There are perhaps $20,000,000$ acres of land in the State that will never be cultivated because of poor climate. The climate, topography, and soil prevent the cultivation of millions of acres. The type of farming is of necessity adapted to the climatic conditions. Wheat and barley are important dry-farm crops because they are successfully grown with slight precipitation. Alfalfa is well adapted to dry climates where irrigation is practised and is ideally grown where, with other conditions satisfactory, the dry, hot, rainless days make it easy to harvest the hay,

At Hyde Park(2) the mean annual precipitation is 16 inches (See Figs. 2 and 3 ), 7 inches of which fall during the six months from April to September, (See Fig. 4). The lowest and highest annual precipitation recorded are 13 inches and 26 inches, respectively, There are 62 days annually with 0.01 inch or more precipitation. The average mean annual temperature is $47.6^{\circ} \mathrm{F}$. with a mean difference between night and day of $21.90 \mathrm{~F} .(3)$, (See Fig. 5). The average number of days in the growing season, between spring and fall killing frosts, is 151 , (See Fig. 6). The dates of the average and absolute last killing frost in the spring and the average and absolute first killing frost in the fall are May 10 and June 17 , and October 8 and September 14 , respective1y. The average and absolute hottest days in the summer are $95^{\circ} \mathrm{F}$. and $100^{\circ}$ F., respectively, while the average and absolute coldest days in winter are $-11^{\circ} \mathrm{F}$, and $-190 \mathrm{~F}$, respectively. The mean temperature for January, the coldest month of the year, is $24.4^{\circ} \mathrm{F}$., and for July, the warmest month of the year, $71.5^{\circ} \mathrm{F}$. The annual rate of evaporation from a free water surface is 45 to 55 inches. The mean humidity during the day is about 50 per cent, (See Figs. 7 to 12 . inclusive).

Topography.-Farming by irrigation is especially dependent on topography. The Hyde Park farm land slopes gently from the mountains west toward the center of the valley. This facilitates irrigation

(1) Brossard, E. B., Utah Exp. Sta. Bul. No. 160 , (Sept., 1917), p. 14.
(2) There is no weather station at Hyde Park. are recorded by the U. S. Weather Bureau for Logan, which is $4 \frac{1 / 2}{2}$
miles south.

(3) West, F. L. and Edlefsen, N. E. Utah Exp. Sta. Bul. No. 166. (March, 1919), p. 9. 


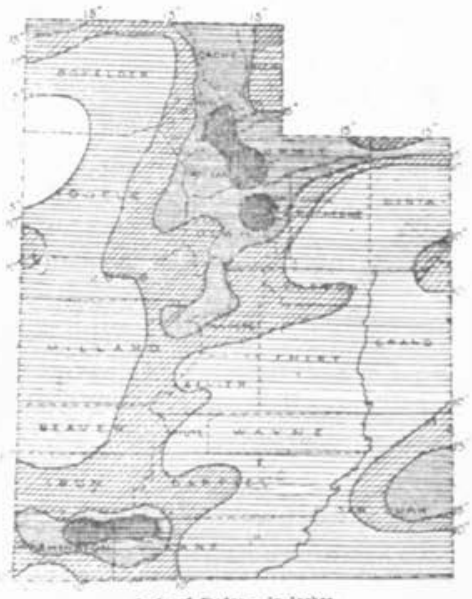

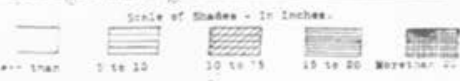

Map Sbowing Annual Precipitation.

Fig. 2.-Average Annual Precipitation. Utah.

(U. S. D. A.. Weather Bureau)

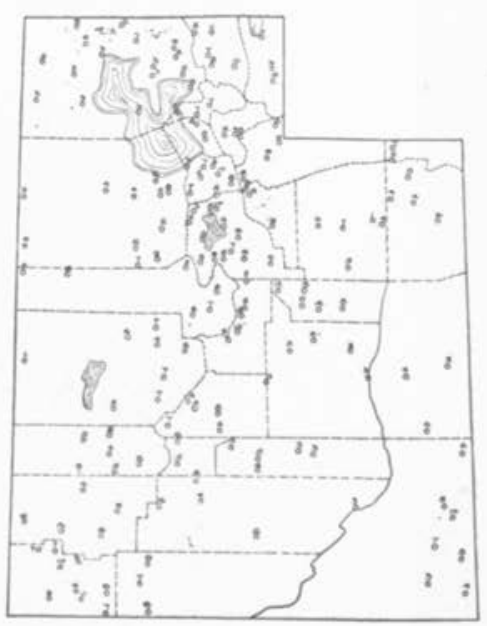

Fig. 4.-Average Precipitation in Crop Growing Season, Utah.

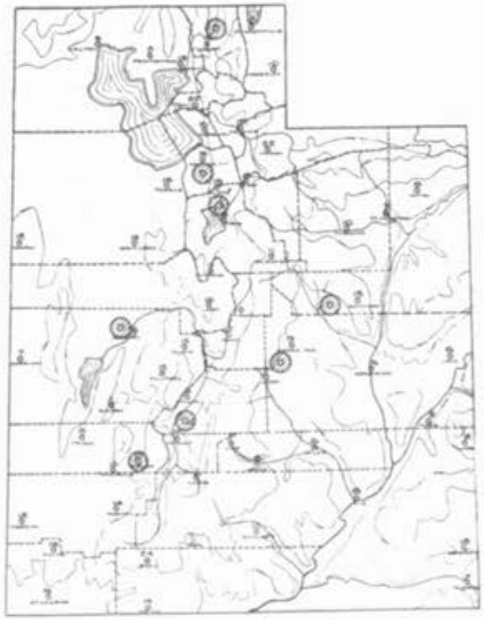

Fig. 3.-Average Annual Precipitation in inches in areas investigated, Utah.

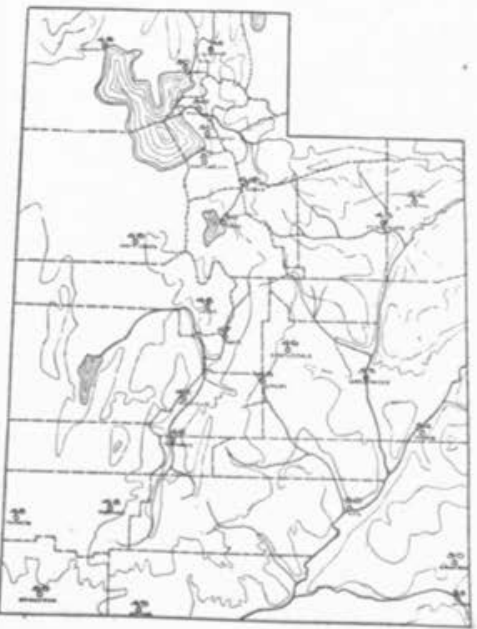

Fig. 5.-Mean Annual Temperature, Utah.

on most of the land, but on some farms the slope is excessive for the best irrigation. The meadows and pastures on the west side of the State road are level and wet where low lying, but dry where the land is slightly elevated or rolling. The arable land is easily worked with the improved machinery. The farmers of Hyde Park who have dry- 


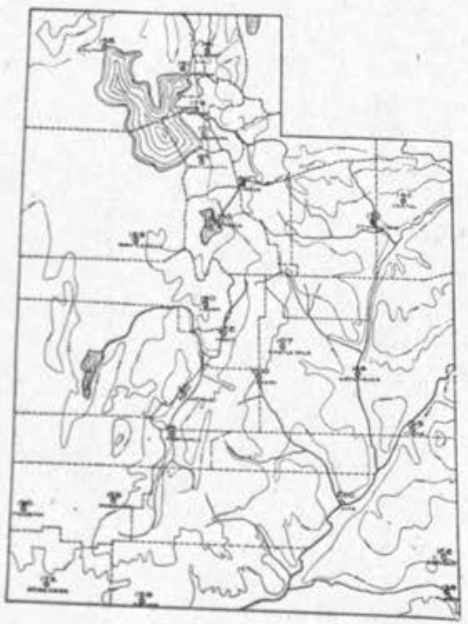

Fig 6.-Average Days in Crop Growing Season, Utah.

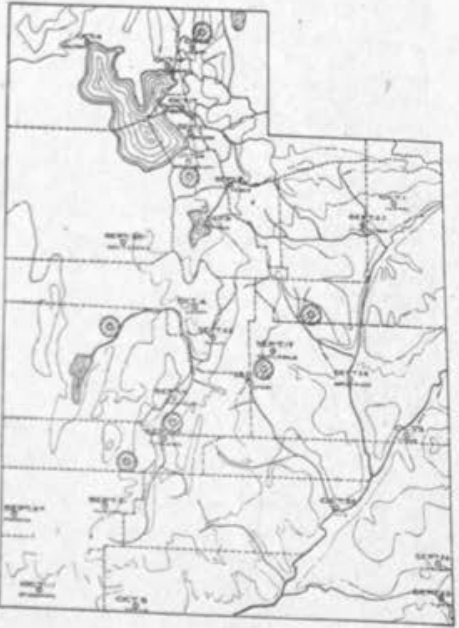

Fig. 8.-Average Date of First Killing Frost in Autumn, Utah.

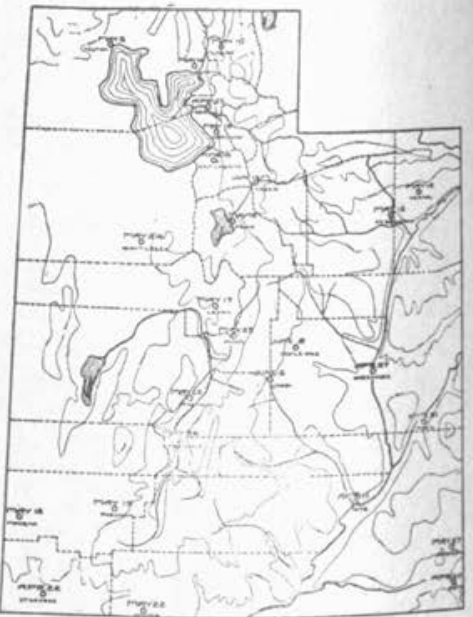

Fig. 7.-Average Date of Last Killing Frost in Spring, Utah.

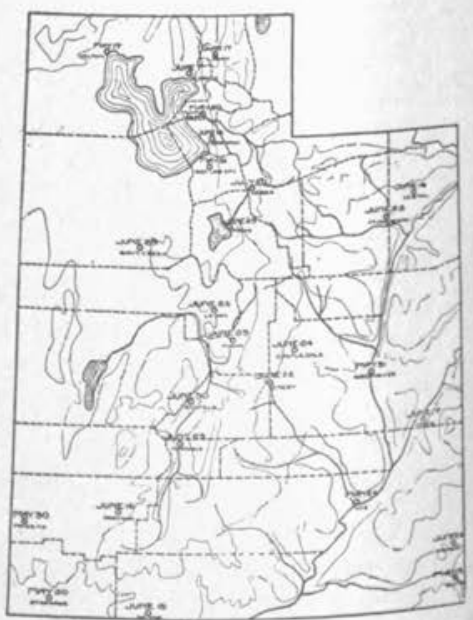

Fig. 9.-Latest Date of Killing Frost in Spring, Utah.

stock or beef cattle, usually graze them east of town on the range afforded by the Cache National Forest. Some, however, who have an keep the dry-stock at pasture that is too wet or too dry for other uses. In a general at home on these pastures.

tised thruent way topography determines the type of farming practised thruout a very large part of the State of Utah. The topographical 


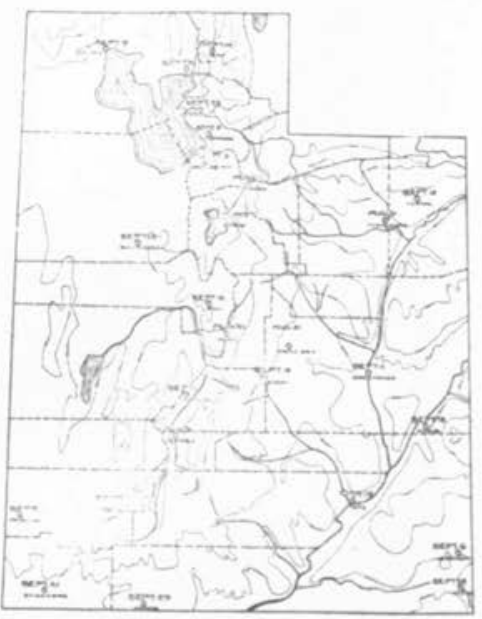

Fig. 10,-Earliest Date of Killing Frost in Autumn, Utah.

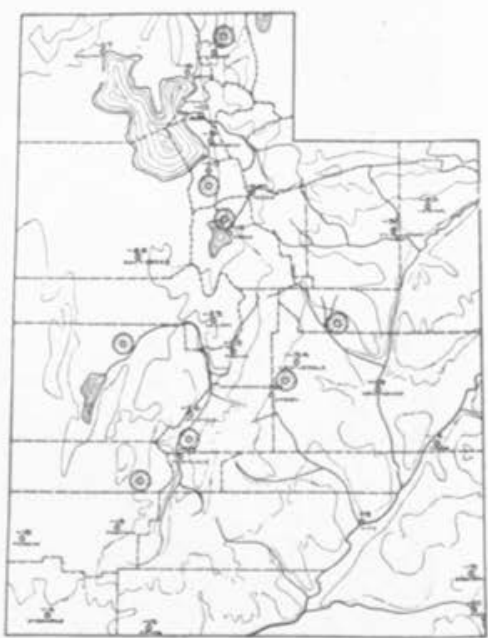

Fig. 12,-Lowest Temperatures Recorded, Utah.

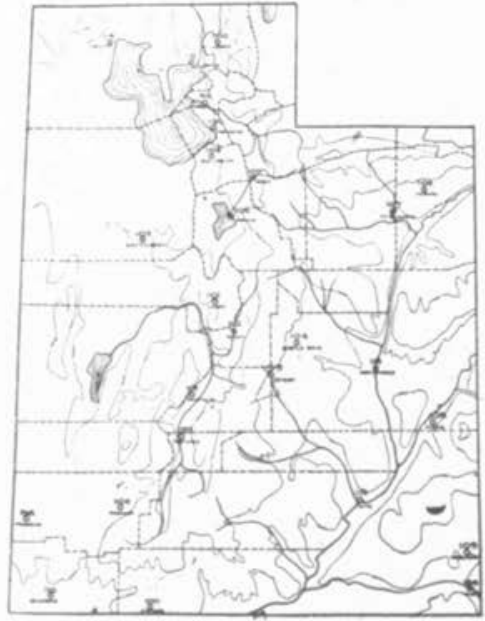

Fig. 11.-Highest Temperatures Recorded. Utah.

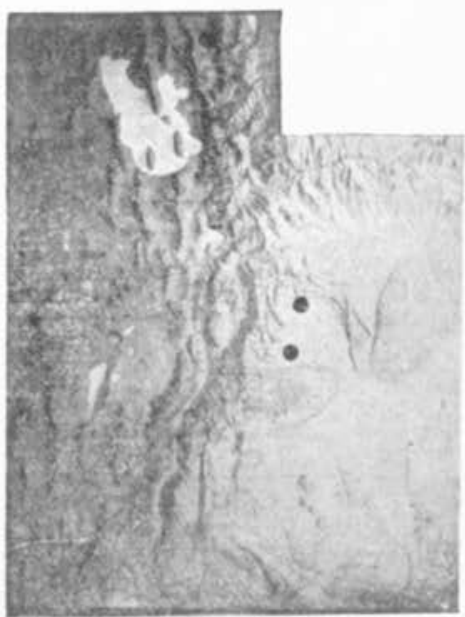

Fig. 13.-Mountains, Valleys,

Lakes, and Streams, Utah.

(Dept. of Geology, U. A. C.)

map, Figure 13, shows the mountains and the valleys of the State. The mountains are not likely ever to be cultivated. This eliminates approximately 40 per cent of the entire State from cultivation. The only agricultural use for this vast area of about $20,000,000$ acres is grazing livestock. On farms conveniently situated this tends to establish a type of farming based upon the grazing of livestock and makes the 
agricultural value of the ranges dependent upon their productivity as grazing lands. It is probable, because of these and other conditions that the livestock enterprises will be of greater importance in the future than in the past( $\left.{ }^{1}\right)$. Especially will this be true on farms conveniently situated.

Soil. -Table IX gives a description of the Hyde Park soil types and the number of farms reporting each type. The descriptions are those given by the farmers themselves and are therefore not technical.

Table IX.-Soil Types and Farms Reporting, 52 Hyde Park Farms, Cache County, Utah.

\begin{tabular}{|c|c|}
\hline Description & Farms Reporting \\
\hline 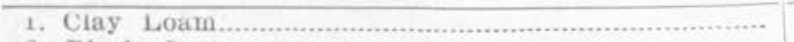 & 21 \\
\hline 2. Black Loam................ & 10 \\
\hline 3. Sandy Loam.... & 10 \\
\hline 4. Gravelly Loam. & 10 \\
\hline 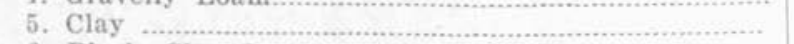 & 5 \\
\hline 6. Black Clay Loam.... & 3 \\
\hline 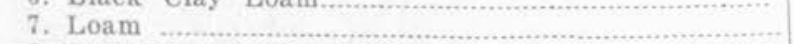 & 2 \\
\hline 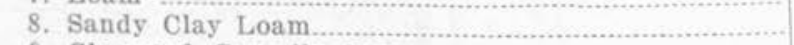 & 2 \\
\hline 9. Clay and Gravelly Loam.... & 2 \\
\hline 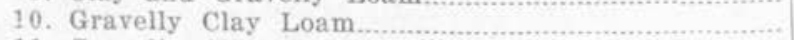 & 2 \\
\hline 11. Gravelly Clay Sandy Loam... & 2 \\
\hline 12. Gravel & 1 \\
\hline
\end{tabular}

There is a great variety of soil types as described by the farmers. The soil on any one farm may vary from heavy clay to coarse gravel. These conditions are typical of the entire Cache Valley.

All of the farming lands of Cache County are in the Bonneville beds (2). (See Figures 14, 15, and 16). The soils were formed from sediments deposited from this ancient lake. Since its subsidence they have been considerably modified by inflowing streams and by weathering. The soils vary from gravel, small gravel and light sand thru all

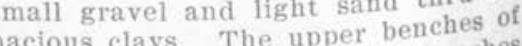
he deltas around the mout most tenacious clays. The the shore benches of Lake Bonneville, are the canyons, and also the shore down into well sravelly soils grading dom from an excess of solls are well underdrained and therefore proper, and to the difficulty of but owing to the thinness of the soil proper, they of applying water and cultivating the soin, these soils have proved very produetive 20 years ago. Since that time dryfarm methods. The soils of the lower benches contain less gravel, but are sandy and of light texture.

Upon the lower and more level parts of the valley there are great variations in the soils. In these streams, where the water movement wasts farthest from the heavy and often contain as high as 50 per cent was slow, the solls are mearer the mouth of strenms, where the water movement was more rapid, the soils are noticenbly lighter, grading thru loam, sandy loam. sandy, or gravelly. Irrigation on the loose soils results in the transportation of considerable sult to the lower and heavier solls, where it is most difficult to get rid of. In Cache Valley there is a large ares of wet clay-land which is

(1) Barnes, W. C., and Jardine, J. T., U. S. D. A. Office of Secretary, Rpt. No, 110 , (July, 1916), pp. 13 to 15 . (1899). 


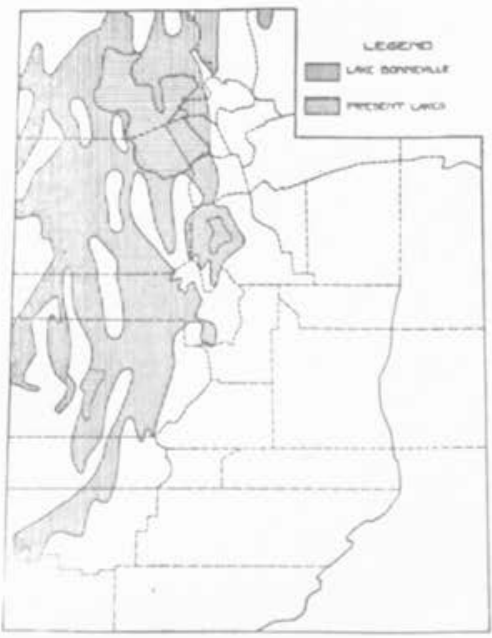

Fig. 14.-Extent of Old Lake Bonneville in Itah. where Soils of the Great Interior Basin Originated. (after J. A. Widtsoe)

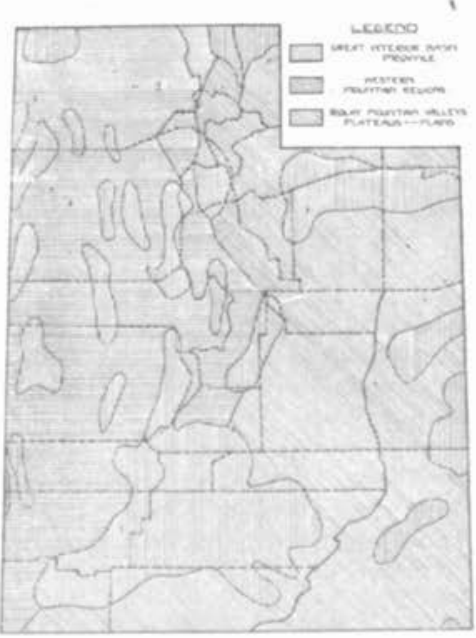

Fig. 15.-Three General Soil Provinces in Utah. (after Milton Whitney)

usen for zendow and grazing, the value of which could be much enhanced by drainage and eultivation. Both black and white alkall are presert in limited spots in the west-central part of the valley. The

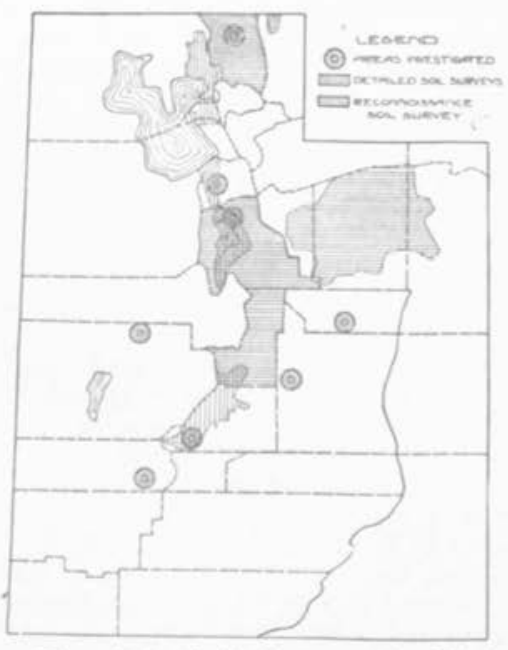

Fig. 16.-Soil Surveys in Utah. black alkali is always associated with the white alkali. Irrigation and seppage waters are the sources of these alkall spots.

Vational Forests and Public Stock Ranges. - The control of grazing on the national forests by the Federal Government has been a benefit to the livestock business and farming in general and thus to the country as a whole. But when the act was passed creating the National Forests, it was not known that it would, (1) eliminate free competition in the use of grazing lands, (2) establish a privileged class of farmers, and (3) determine the type of farming on many farms adjacent to the reservations. Yet this is what has happened. This situation is admitted but at present no good solution of the problem is advanced.

The Cache National Forest borders the dry-farm land east of Hyde Park and includes the mountains. (See Figure 17). In 1916 there were 833.898 acres of land within its boundaries, 319,581 acres of which were in Utah and 514,317 acres in Idaho(1). Of the 319,581 acres in Utah,

(1) Kneipp, L. F., Third Annual Rpt. Utah Bu. Immigration, Labor. and Statistics, (1916), pp, 184-5, "Utah's Forest Resources." 
52,515 were private lands within the forest and 267,066 acres were the net national forest lands.

The average grazing season is 5 to 8 months long. On the average, for the three years 1914,1915 , and 1916 , there were 21,750 head of cattle and horses, and 132,467 sheep and goats grazed on the 833,898 acres less the privately owned land in both Utah and Idaho. In other words there are 40,674 animal units grazed here, or 1 animal unit to about 17 acres. This is the estimated grazing capacity of the forest(1). This shows that the Cache National Forest is now grazed to its capacity.

Farmers who had stock to put on the ranges at the beginning of regulation have the prior right today. They are desirous of increasing the number allowed them under their permits. New farmers want to get stock on the ranges. This is difficult. In order to do so they must get a permit from the Federal Government. There are three ways of

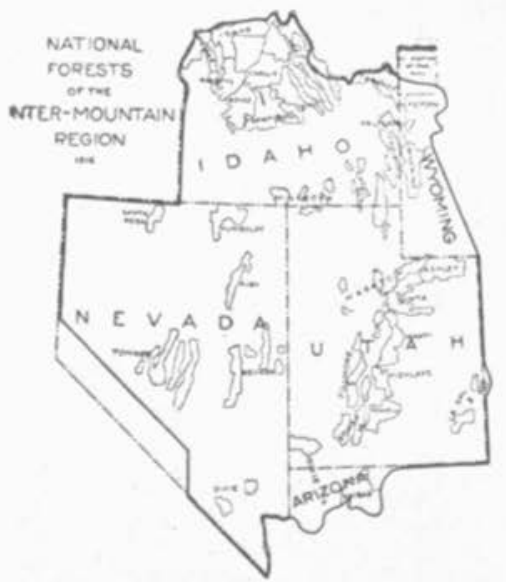

Fig. 17.-National Forests of Intermountain Region. (after L. F. Kneipp) obtaining permits: (1) buy one from some farmer at the same time as you buy his farm; (2) wait your turn until some one goes out of the business, or so reduces his herd as to allow other animals on the range; or (3) await the improvement of the range, by the regulations of the Federal Government, so that its capacity is increased. By either the second or third method, but few stock may be added at a time, and in most cases it is poor economy to have so few head on the range.

The deciding who shall have stock on the ranges, and how many each shall have, is a function of the District Forester, who is an official of the Federal Government. This may or may not be a good thing. In the past it has undoubtedly been a benefit. But all that it is necessary to point out here is that the Federal Government thus becomes a very important factor in determining the type of farming on the farms of the Intermountain States. This is particularly true in Utah and especially in Cache County and Hyde Park.

Table $\mathrm{X}$ shows the value of all domestic animals on farms and ranges by counties in Utah, April 15, 1910. A comparison of Table $\mathrm{X}$ and Figure 17, giving the location of the National Forests, shows that more livestock are kept in the districts where the ranges are located.

Population.-From the early settlement at Salt Lake City (1847) others soon developed both north and south wherever irrigation water was available and the soil and climate made agriculture possible. (See Figure 18). The settlement of Hyde Park began in 1860 or about 60 years ago. The climate of Hyde Park is delightful because of the light and infrequent rains, the clear and sunshiny days, the dry ground underfoot, the dry air, and the mild wind with a velocity of but five miles an hour. While these factors contribute to a pleasant and agreeable habitat for man, at the same time they make it necessary to irrigate most of the crops of Cache County and the State and make vegetation
light where irrigation is impossible.

(1) Barnes, Will C., and Jardine, J. T., U. S. D. A., Office of Sec., Rpt. No. 110 , (July, 1916 ), p. 87 . 
Table X.- Value of all Domestic Animals on Farms and Ranges, by Coupties, Utah, April 15, 1910 (1)

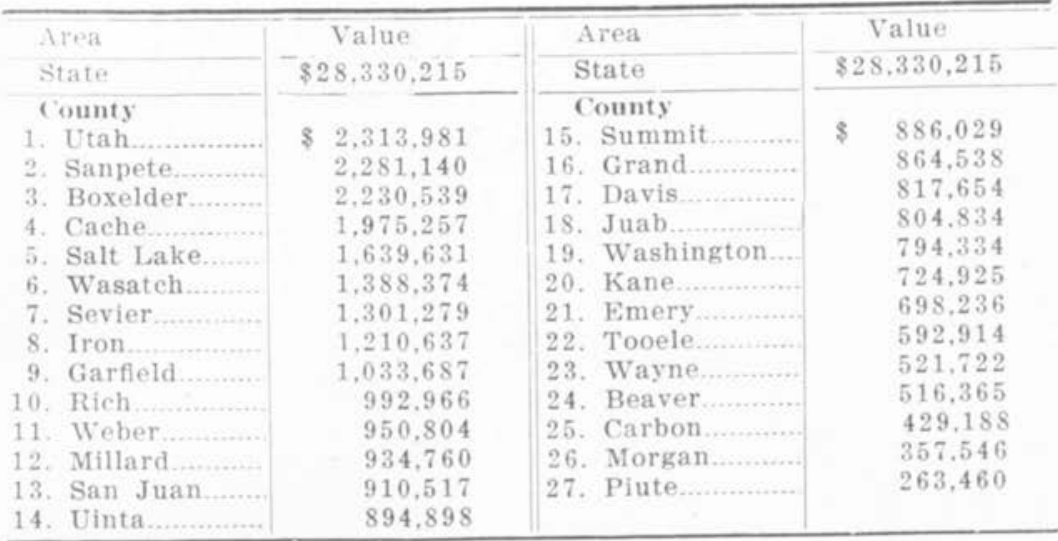

Hyde Park had a population of 699 according to the 1910 census. The character of its population is assumed to be about the same as of Cache County as given by the 1910 United States census.

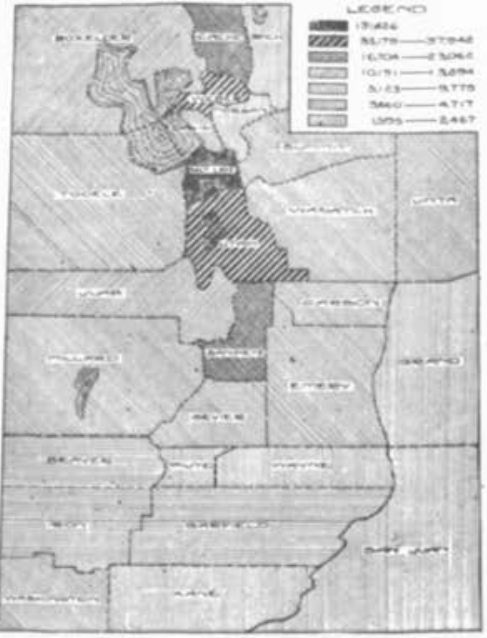

Fig. 18.-Distribution of Population by Counties, Utah. (1910 U. S. Census)

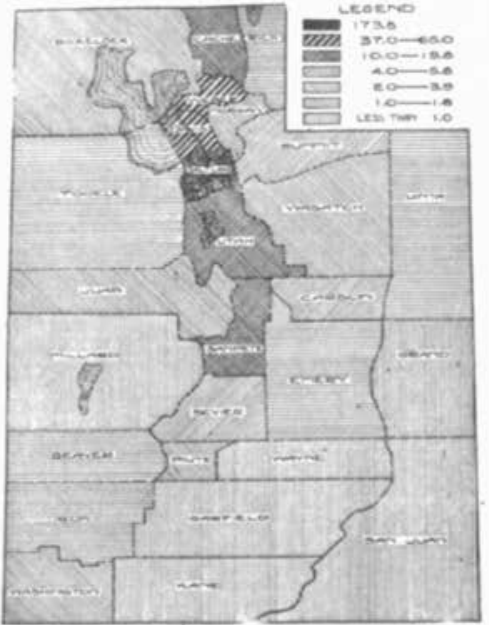

Fig. 19.-Density of Population (Persons per sq. mi.) by Counties, Utah. (1910 U. S. Census).

The population for Cache County was 23,062 in $1910 ; 18,139$ in $1900 ; 15,509$ in $1890 ; 12,562$ in $1880 ; 8,229$ in $1870 ;$ and 2,605 in 1860 . In 1910 there were 11,458 males and 11,604 females in the

(1) 1910 U. S. Census. 
county. There were 19.8 persons per square mile. But the density of the rural population was 13.4 persons per square mile. (See Figure 19).

of the total population 46.3 per cent was urban and 53.7 per cent was rural. There were only 64 colored people in the county, 7 of whom were negroes, 5 males and 2 females, and 57 indians, chinese, japanese, and all others.

There were 5,230 males of voting age, 64 of whom were illiterate, or 1.2 per cent. Of all persons 10 years old and over, 215 , or 1.3 per cent were illiterate. There were 8,399 persons, 6 to 20 years old inclusive, 5,982 of whom, or 71.2 per cent were attending school. There were 9,800 native whites of native parentage, 9,421 native whites of foreign or mixed parentage, and 3,777 foreign-born whites. Of the 3,777 foreign-born whites in the county, 979 came from England, 825 from Denmark, 651 from Sweden, 405 from Switzerland, 272 from Norway, 201 from Germany, 149 from Scotland, 127 from Wales, 42 from Canada, 32 from Italy, 18 from Ireland, 14 from Australia, 9 from Greece, 9 from Mexico, 8 from Russia, 5 from Austria, 4 from Finland, 2 from France, 2 from Holland, 1 from Hungary, and 22 from other foreign countries such as Japan, China, India, etc.

There were 4,125 native whites both of whose parents were born in the same foreign country. The parents of 1,463 of these native whites came from England, 1,019 from Denmark, 556 from Sweden, 325 from Switzerland, 225 from Norway, 221 from Scotland, 148 from Wales, 111 from Germany, 23 from Italy, 11 from Canada, 11 from Ireland, 6 from Russia, 3 from France, and 3 from Holland.

It should be noted that most of the foreign-born whites and also the parents of the native-born whites of foreign parentage came from Great Britain and the countries of northwestern Europe. The people of these countries are usually industrious and thrifty. The type of farming practised in these foreign countries is similar in many ways to that practised at Hyde Park. The root crops, especially sugar-beets, were no doubt familiar to these persons before they came to this country. These persons were also undoubtedly familiar in some degree with the small-grains and hay. They also knew something about machine methods in general farming. These conditions had some influence on their settling at Hyde Park and the type of farming followed there.

Between 15 and 20 per cent of the rural male population of the

Table XI.-Size of Family, Acres Sugar-Beets Raised, and Cows Milked, Hyde Park, Cache County, Utah, 1914

\begin{tabular}{|c|c|c|c|c|c|c|c|}
\hline $\begin{array}{c}\text { Size of Farm } \\
\text { Family(1) }\end{array}$ & 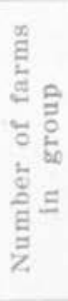 & 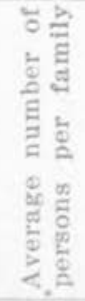 & 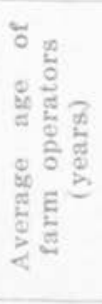 & 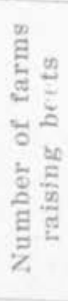 & 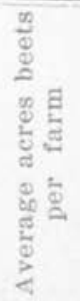 & 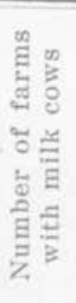 & 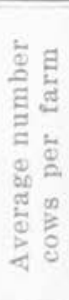 \\
\hline All Farms.... & 45 & 7.4 & 45 & 41 & 10.4 & 43 & 7.4 \\
\hline $\begin{array}{l}\text { Small } \\
\text { Medium ......... } \\
\text { Large }\end{array}$ & $\begin{array}{l}16 \\
17 \\
12\end{array}$ & $\begin{array}{r}4.6 \\
7.7 \\
10.6\end{array}$ & $\begin{array}{l}44 \\
43 \\
48\end{array}$ & $\begin{array}{l}15 \\
15 \\
11\end{array}$ & $\begin{array}{r}8.3 \\
9.2 \\
13.9\end{array}$ & $\begin{array}{l}15 \\
16 \\
12\end{array}$ & $\begin{array}{l}6.0 \\
7.1 \\
9.6\end{array}$ \\
\hline
\end{tabular}

(1) The Small Farm Famflies had from 2 to 6.9 members, the Medium Farm Families had from 7 to 8.9 members, and the Large Farm Familles included those having from 9 to 14 persons each. 


\section{Some Types of Irrigation Farming in Utah}

State are foreign-born whites and therefore in studying the type of farming and its causes this factor should not be neglected. In 1910 the total rural population of the State was 200,417 , males 107,810 and fomales 92,607. There were 86,273 native-white males and 79,427 mative-white females, and 18,358 foreign-born white males and 11,641 foreign-born white females. There were only 118 negro males and 67 negro females in the State, and 1,661 indian males and 1,441 indian females. Forty-eight and three-tenths per cent of all rural males were under 20 years of age and 48.1 per cent of all rural males were between the ages of 20 and 64 years. Fifty-four and three-tenths per cent of all rural females were less than 20 years old.

The Farm Family. - The Hyde Park farms are family-sized farms. One manager is all that is required on any of them and he does the greater part of the farm work. There is only one farm on which there is a man hired for the entire year. Most of the farm labor is performed nither by the farmer himself, unpaid family labor, or is hired by the month. day, or piece as needed during critical or rush seasons of the year.

There were 4,623 families in Cache County in $1910(1)$ and 4,430 lwellings, or 104 families to each 100 dwellings. The average number of persons in a family was 5 , and the average number in a dwelling 5.2 . For the State the average number of persons in a family was 4.8 , and the average number in a dwelling 5.1 , as compared with 4.5 and 5.2 persons in each family and in each dwelling respectively in the United States. The families are larger in Cache County than the average of the State, and the average of the State is larger than the average of the United States.

The average number of persons in the farm families included in this investigation in 1914 is 7.4 , but only 6 of these persons were on the farm at the time it was visited. Hyde Park farm families are larger than the average Cache County farm family. The raising of children well is a part of the mission of every married couple according to the religious teaching of most of these farmers. Babies are most welcome in these farm homes. Consequently a type of farming is adopted that makes it possible to raise numerous children. Children while young are able to milk cows and thin sugar-beets to good advantage and thus contribute to the family income and help make their own living. Table XI shows that on those farms with the large families more acres of sugar-beets are raised and more milk cows are kept than on the farms with small families. The type of farming practised seems to have a definite relationship to the size of the farm family.

Table XII does not show a marked correlation between size of farm family and labor income, because unpaid family labor has been subtracted as an expense in determining this figure. There is, however, a marked correlation between the size of family and crop acres, farm iseome, value of unpaid family labor, and family income. These facts indfeate that the entire farm family is the basic unit around which the farm business is organized.

Farmers, like the other factors of production, land and capital. have two dimensions of productivity, capacity and efficiency (2). The farm home is one of the factors that contributes to the productivity of the farmer. The converse of this is also true. The productivity of the farmer largely determines his type of farm home. These two factors affect each other in such a way as to be called reciprocating factors. The farmer being born in a home is first affected by the home and sub-

(1) 1910 United States Census.

(2) Taylor, H. C., Am. Econ. Rev. Supp. Vol. VII, No. 1, (March) 1917). "Two Dimensions of Productivity.," 
Table XII. - Size of Farm Family, Labor Income(1), Value of Unpaid Family Labor(2), Farm Income(3), and Family Income(4), Hyde Park, Cache County, Utah, 1914

\begin{tabular}{|c|c|c|c|c|c|c|c|}
\hline $\begin{array}{l}\text { Size of } \\
\text { Farm } \\
\text { Family }\end{array}$ & 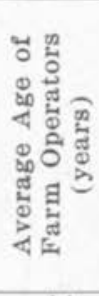 & 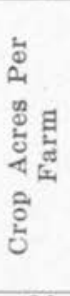 & 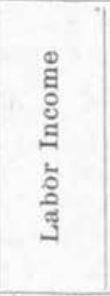 & 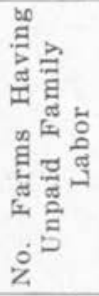 & 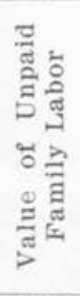 & 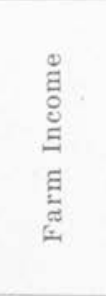 & 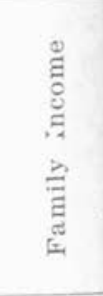 \\
\hline Small ...... & 44 & 39 & $\$ 600$ & 6 & $\$ 126$ & $\$ 1,066$ & $\$ 1,192$ \\
\hline Medium ... & 43 & 50 & 1,156 & 14 & 246 & 1,833 & 2,076 \\
\hline Large .... & 48 & 77 & 897 & 12 & .414 & 1,898 & 2,312 \\
\hline
\end{tabular}

(1) Labor income was obtained by subtracting from the farm receipts, the farm expenses and interest on the average capital investment: Interest. in this case was figured at 5 per cent but should have been figured at 8 per cent. (See paragraph on Farm Profits). The value of hired labor was counted as an expense but no personal or living expenses were counted. If the farmer's sons or other members of the family did farm work without pay, their labor was counted as an expense and rated at what they would have received had they worked for their neighbors, or what it would have cost to have hired the work they did. Any increase in stock, feed, or other inventory items was counted as a receipt; a decrease was counted as an expense. Any increase in the value of land which might be thought of as unearned increment was not included as a receipt, but increases in land values due to improvements have been counted as receipts and the amount of the increase allowed was the same as the expense of the improvement. No credit has been allowed for the farm products that were used in the farm home. The farm house has been considered as part of the farm capital investment.

(2) The value of unpaid family labor was estimated on the basis of wages paid by neighbors for similar work and workmen and also on the basis of what it would cost to hire the same work done on the farm in cuestion. The child labor employed doing chores was not included when the tasks they performed would have been done by their father or some other member of the family, had they not been performed by the smaller children. No charge in farm expenses was made for child labor that just relieved the father or older brother from some menial task which they would have done themselves rather than hire it done. No charge for child labor should be made unless there is an actual opportunity value for the labor and then the charge should be made on the basis of the opportunity value. But sometimes it is difficult to estimate this opportunity value. Such cases arose at Hyde Park and the unpaid family labor was valued on the basis of what it would cost the individual farmer to hire such work done. It is evident that in either case the information rests on estimates. In the one case one estimates the amount of labor each child or grown boy or girl does, and in the other case he estimates the opportunity value of the labor at the given time.

( ${ }^{3}$ ) Farm income was obtained by subtracting the farm expenses from the farm receipts. It is labor income plus interest.

(4) Family income is the sum of the farm income and the value of unpaid family labor. It does not include the farm produce used in the house, house rent, or unearned increase in land value. 
sequently his own personal productivity affects his home. Table XIII shows the great variation in the value of the dwellings of the Hyde Park farmers. Two-thirds of these farm dwellings are valued at $\$ 1000$ and over and one-third of them are worth less than $\$ 1,000$.

Table XIII.-Value of Farm Dwellings, 50 Farms, Hyde Park, Cache County, Utah, 1914

\begin{tabular}{|c|c|}
\hline Range of Value of Farmhouse & Number of Farms \\
\hline$\$ 100$ to $\$ 4,000$ & 50 \\
\hline 500 or less & 10 \\
\hline 501 to $\$ 999$ & 7 \\
\hline 1,000 to 1,499 & 11 \\
\hline 1.500 to 1.999 & 8 \\
\hline 2,000 to 2,499 & 9 \\
\hline 2.500 or over & 5 \\
\hline
\end{tabular}

Table XIV.-Relation of Value of Farm Home and Labor Income, Hyde Park, Cache County, Utah, 1914

\begin{tabular}{c|c|c|c|c}
\hline $\begin{array}{c}\text { Group of Farms } \\
\begin{array}{c}\text { According to } \\
\text { Value of Farm } \\
\text { Home }\end{array}\end{array}$ & $\begin{array}{c}\text { Number } \\
\text { of Farms } \\
\text { in } \\
\text { Group }\end{array}$ & $\begin{array}{c}\text { Average } \\
\text { Value } \\
\text { of Farm } \\
\text { Home }\end{array}$ & $\begin{array}{c}\text { Average } \\
\text { Labor } \\
\text { Income }\end{array}$ & $\begin{array}{c}\text { Average } \\
\text { Farm } \\
\text { Income }\end{array}$ \\
\hline 11 Farms.......... & 49 & $\$ 1321$ & $\$ 863$ & $\$ 1537$ \\
$\$ 100$ to $\$ 1000 \ldots .$. & 17 & 479 & 914 & 1462 \\
$\$ 1000$ to $\$ 2000 .$. & 19 & 1274 & 806 & 1455 \\
$\$ 2000$ and over.. & 13 & 2492 & 880 & 1753 \\
\hline
\end{tabular}

Table XV.-Relation of Value of Farm Home and Labor Income, Hyde Park, Cache County, Utah, 1914

\begin{tabular}{c|c|c|c|c}
\hline $\begin{array}{c}\text { Group of Farms } \\
\text { According to } \\
\text { Value of Farm } \\
\text { Home }\end{array}$ & $\begin{array}{c}\text { Number } \\
\text { of Farms } \\
\text { in } \\
\text { Group }\end{array}$ & $\begin{array}{c}\text { Average } \\
\text { Value } \\
\text { of Farm } \\
\text { Home }\end{array}$ & $\begin{array}{c}\text { Average } \\
\text { Labor } \\
\text { Income }\end{array}$ & $\begin{array}{c}\text { Average } \\
\text { Farm } \\
\text { Income }\end{array}$ \\
\hline All farms......... & 49 & $\$ 1321$ & $\$ 863$ & $\$ 1537$ \\
\hline$\$ 100$ to $\$ 800 \ldots \ldots$. & 14 & 410 & 961 & 1446 \\
$\$ 800$ to $\$ 1500 .$. & 14 & 1000 & 796 & 1498 \\
$\$ 1500$ and over & 21 & 2029 & $\$ 48$ & 1623 \\
\hline
\end{tabular}

Tat if XV:- Fielation of Value of Farm Home and Labor Income, Hyde Park, Uache County, Utah, 1914

\begin{tabular}{l|c|c|c|c}
\hline $\begin{array}{c}\text { Group of Farms } \\
\begin{array}{c}\text { According to } \\
\text { Value of Farm } \\
\text { Home }\end{array}\end{array}$ & $\begin{array}{c}\text { Number } \\
\text { of Farms } \\
\text { in } \\
\text { Group }\end{array}$ & $\begin{array}{c}\text { Average } \\
\text { Value } \\
\text { of Farm } \\
\text { Home }\end{array}$ & $\begin{array}{c}\text { Average } \\
\text { Labor } \\
\text { Income }\end{array}$ & $\begin{array}{c}\text { Average } \\
\text { Farm } \\
\text { Income }\end{array}$ \\
\hline All Farms......... & 49 & $\$ 1321$ & $\$ 863$ & $\$ 1537$ \\
\hline 100 to $\$ 1200 \ldots$. & 25 & 646 & 909 & 1510 \\
$\$ 1200$ to $\$ 2000 \ldots$ & 11 & 1473 & 739 & 1249 \\
$\$ 2000$ and over.. & 13 & 2492 & $\$ 80$ & 1753 \\
\hline
\end{tabular}


Altho it may seem reasonable to expect that farmers who make the largest labor incomes should have the more expensive homes, or that the farmers who have the more expensive homes should make the largest labor incomes, yet Tables XIV, XV, and XVI show that there is in reality no correlation between the value of the farm dwelling and the farmer's 1 bor income. This illustrates how easily one may be mistaken in judging the prosperity of a farmer by the size and elegance of his dwelling house.

Farm Labor.-It has been shown how family labor affects type of farming. Hired labor is also a determining element. At Hyde Park, in 1914, the average amount of labor employed on each farm was equivalent to $1.6 \mathrm{men}$, including the farm operator. This is equivalent to 1 man, the operator, twelve months ( 1 year), and 7 months and 6 days of additional man labor. In 1915 the average number of men on the 48 Hyde Park farms was 1.6 and on the 10 better-paying farms 1.5 .

In 1914 there were 11 farmers who hired help by the month. Only 1 of these farms hired a man by the year. On the average, annual wages for month-help on each farm amounted to $\$ 230$. Nine farms boarded help at least part of the time, the estimated average cost of which amounted to \$55. Thirty-three farmers hired extra help (paid by month, day, or piece) during the rush season, usually thinning beets, hoeing or harvesting beets, or harvesting grain or hay, the cost of which averaged $\$ 128$ for each farm. Thirty-two farms had, on the average, $\$ 286$ worth of unpaid family labor. Including all farms of the area, the average value for each farm, of regular hired labor, extra labor, board of hired labor, and unpaid family labor, was $\$ 387$. The farmers' estimates(1) of the value of their own labor for the year varied from $\$ 200$ to $\$ 1,000$, and averaged $\$ 600$. Therefore, the average value of all labor on each farm, in 1914 , was $\$ 600$ plus $\$ 387$, or $\$ 987$. The average amount paid for hired labor in 1916 on the 32 farms at Hyde Park was \$127. Unpaid family labor averaged $\$ 87$. The total value of labor other than the operator's, was, therefore, $\$ 214$ as compared with $\$ 387$ in 1914 .

The hoeing and cultivating of beets begins about two or three weeks after thinning. Beets are hoed from three to seven times during the season. They are irrigated from two to seven times a season, altho if done at the proper season, three to four times are sufficient(2). The hoeing and cultivating is usually done just after irrigation. The plowthe grain is taken off.

The critical labor periods in the type of farming practised at Hyde Park are during beet thinning, fall plowing, fall planting, and beet pulling. The summer care of beets and potatoes conflicts as does also in the spring. This is one reason here. When alfalfa or other hay why more potatoes are not grown and haying begins. The beet work is resu to eut the beet work stops As nearly as possible the irrigating is doned as soon as the hay is up. Sometimes both the beets and the alfalfac when the crops need water. thus a critical labor situation may arfa need it at the same time and rule, the labor on these crops is not arise in irrigating. As a general be done. (See Table XVII). The labor

(I) Based upon what he could hire out for to some one else. Some had had offers of positions and others estimated according to wages
paid for labor they were able to perform.

(2) Harris, F. S., Utah Agr. Exp. Sta. Bul. No. 156, (June, 1917). 
Table XVII.-Order of Crop Work at Hyde Park, Cache County, Utah(1)

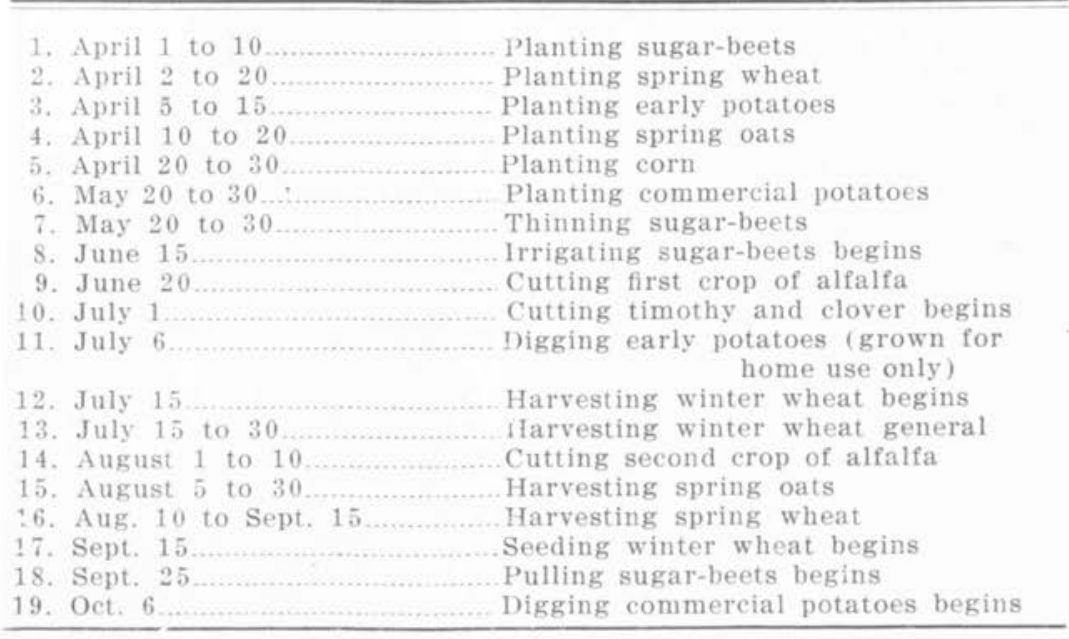

is largely non-competitive. The crop and stock enterprises are complimentary (2) to a considerable extent.

It is not at all necessary that the farming business be so organized as to have the same labor requirements for each month of the year. In winter, children are in school, high school, and college, but in summer they are at home and available for farm work. Growing sugar-beets at Hyde Park supplies profitable employment for this seasonal supply of farm labor. The school children of Logan and the smaller towns of the county do much of the labor on the sugar-beet erop of Cache County.

Man labor efficiency is indicated by the ratio of men to crop-acres and units of livestock. In 1914 the ratio of men to crop-acres was 1 to 33 on the average of all 52 farms and 1 to 52 on the 10 betterpaying farms. In 1915 the ratio was 1 to 33 on the average of all 48 farms, 1 to 31 on the average of the 10 least-profitable farms, and 1 to 42 on the average of the 10 better-paying farms. It must be remembered in this connection that the men who cared for the greater number of acres of crops were operating farms larger than the average.

The ratio of men to productive animal units was 1 to 9 on the average of all 52 farms in 1914 and 1 to 12 on the average of the 10 hetter-paying farms. In 1915 this ratio was 1 to 10 on,the average of all 48 farms, 1 to 10 on the average of the 10 least-profitable farms, and 1 to 14 on the average of the 10 better-paying farms. (See Tables I and II in Appendix).

The paragraphs immediately preceding have shown the amount of hired labor used, the average cost of hired labor, the seasonal requirements of labor, the critical labor periods, the labor conflicts on crop and stock enterprises, the immediately available supply of labor, and the efficiency of man labor with crops and stock on the Hyde Park farms. In Tables XVIII, XIX and XX, which follow, some of these factors are given for the State as a whole and for the individual counties in order

(1) Baker, O. E., and others, U. S. D. A. Yearbook, (1917), pp. 537 to 591 , or Yearbook Separate No. 758 .

(2) Connor, L. G., Utah Exp. Sta. Bul, No. 165, (Oct., 1918), p. 21. Table XVII. 
to indicate roughly the general farm labor situation. Table XVIII shows the number and occupation of all males and females 10 years of age or over engaged in agriculture in Utah in 1910. In the order of numbers employed in agriculture the occupation classes rank as follows: (1) Farmers and Dairy Farmers, males 7,606, females 479; (2) Farm and Dairy Farm Laborers working out, males 7,807 , females 255 ; (3) Farm Laborers, home farm, 5,827; (4) Stock Herders, Drovers, and Feeders, 2,207; (5) Stock Raisers, 1,350; (6) Gardeners, 398; (7)

Table XVIII.-Persons 10 Years of Age or Over, Engaged in Agriculture in Utah, $1910(1)$

\begin{tabular}{|c|c|c|c|c|c|c|}
\hline Occupation (2) & Total & $\begin{array}{l}10-13 \\
\text { Years }\end{array}$ & $\begin{array}{l}14-15 \\
\text { Years }\end{array}$ & $\begin{array}{l}16-20 \\
\text { Years }\end{array}$ & $\begin{array}{l}21-44 \\
\text { Years }\end{array}$ & $\begin{array}{l}45 \text { and } \\
\text { Over }\end{array}$ \\
\hline Males ................................. & $|35,876|$ & 914 & 1,183 & 5,490 & 18,443 & 9,837 \\
\hline 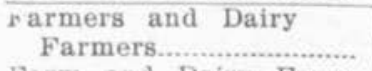 & $|17,606|$ & ....... & $\mid \ldots . . .$. & 207 & 9,687 & 7,712 \\
\hline $\begin{array}{l}\text { Farm and Dairy Farm } \\
\text { Laborers (Working out) } \\
\text { Farm Laborers }\end{array}$ & 7,807 & 147 & 304 & 2,065 & 4,383 & 908 \\
\hline $\begin{array}{l}\text { (Home Farm) ............... } \\
\text { Stock Herders, Drovers, }\end{array}$ & 5,827 & 743 & 826 & 2,675 & 1,499 & 84 \\
\hline and Feeders....................... & 2,207 & 17 & 36 & 458 & 1,560 & 136 \\
\hline 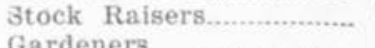 & 1,350 & & ...... & 24 & 861 & 465 \\
\hline $\begin{array}{l}\text { Gardeners } \\
\text { Fruit Growers and Nur- }\end{array}$ & 398 & $\ldots$ & ....... & 5 & 140 & 244 \\
\hline 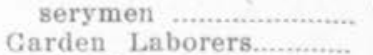 & $\begin{array}{l}313 \\
228\end{array}$ & & & 1 & 145 & 167 \\
\hline urchard and Nursery & 228 & 5 & 12 & 25 & 82 & 103 \\
\hline Laborers ............................ & 140 & 11 & 5 & $30 \mid$ & 861 & 18 \\
\hline F'emales .................................. & 734 & 34 & 29 & $66 \mid$ & 202 & 403 \\
\hline $\begin{array}{l}\text { Farm and Dairy Farm } \\
\text { Laborers } \\
\text { Farmers and Dairy } \\
\text { Farmers }\end{array}$ & 255 & 34 & 29 & 611 & 72 & 59 \\
\hline Farmers .............................. & 479 & $\ldots . .$. & …… & 5 & 130 & 344 \\
\hline
\end{tabular}

(1) 1910 U. S. Census, Vol. IV., Population-Occupation Statistics, Table VII, p. 523 .

(2) Ibid.

(a) A Farmer-A person who is in charge of a farm whether he owns it or operates it as a tenant, renter, or cropper.

(b) A Farm Manager-A person who manages a farm for some one else for wages or salary.

(c) A Farm Laborer-A person who works on a farm for someone else but not as a manager, tenant, or cropper.

(d) A Woman Farmer-A woman who herself operates or runs a farm.

(e) A Woman Farm Laborer-A woman working regularly at outdoor farm work, even though she works on the home farm for her husband, son, or other relatives, and does not receive money wages. Women farm laborers are separated into two classes: (1) those working on the 'home farm', and (2) those 'working out'.

(f) Children on Farms-Children who work for their own parents on a farm are classed as Farm Laborers on Home farm; but children who work on a farm for others are classed as Farm Laborers working out. 
Frut Growers, and Nurserymen, 313; (8) Garden Laborers, 228; and 19) Orchard and Nursery Laborers, 140. A total of 35,876 males and 734 females or a grand total of 36,610 persons 10 years old or over were gainfully employed in agriculture in Utah in 1910, which is 1 for each 10.2 persons in the State.

Table XIX.-Average Cost of Hired Labor on Farms, by Counties, Utah, $1910(1)$

\begin{tabular}{|c|c|c|c|}
\hline & $\begin{array}{c}\text { Cash } \\
\text { Expended } \\
\text { per Farm }\end{array}$ & $\begin{array}{l}\text { Rent and Board } \\
\text { Furnished } \\
\text { per Farm }\end{array}$ & $\begin{array}{c}\text { Cash, Rent, and } \\
\text { BoardFurnished } \\
\text { per Farm }\end{array}$ \\
\hline The State........... & $\$ 242.58$ & $\$ 25.94$ & $\$ 268.52$ \\
\hline Beaver & 179.94 & 33.60 & 213.54 \\
\hline Boxelder ............ & 413.73 & 40.75 & 454.48 \\
\hline Cache ........... & 197.32 & 20.16 & 217.48 \\
\hline Carbon & 309.97 & 58.92 & 368.89 \\
\hline Davis ... & 211.22 & 24.40 & 235.62 \\
\hline Emery. & 270.15 & 82.84 & 352.99 \\
\hline Garfield & 191.65 & 2.56 & 194.21 \\
\hline Grand ....... & 645.46 & 218.35 & 863.81 \\
\hline Iron ......... & 400.47 & 33.08 & 433.55 \\
\hline Juab & 253.23 & 14.44 & 267.67 \\
\hline Kane ... & 507.29 & 5.77 & 513.06 \\
\hline Millard .... & 223.20 & 23.31 & 246.51 \\
\hline Morgan ....... & 187.25 & 19.31 & 206.56 \\
\hline Piute ......... & 227.09 & 34.11 & 261.20 \\
\hline Rich ............ & 774.00 & 206.11 & 980.11 \\
\hline Salt Lake... & 228.87 & 15.24 & 244.11 \\
\hline San Juan... & 553.84 & 157.08 & 710.92 \\
\hline Sanpete ... & 173.63 & 13.20 & 186.83 \\
\hline Sevier ... & 165.56 & 21.66 & 187.22 \\
\hline Summit & 421.78 & 68.96 & 490.74 \\
\hline Tooele .. & 324.02 & 54.30 & 378.32 \\
\hline Uinta & 212.16 & 48.15 & 260.31 \\
\hline Utah ............... & 187.93 & 10.91 & 198.84 \\
\hline Wasateh ... & 182.06 & 21.88 & 203.94 \\
\hline Washington .... & 193.82 & 16.23 & 210.05 \\
\hline Wayne ............. & 168,66 . & 38.91 & 207.57 \\
\hline Weber & 222.70 & 14.74 & 247.44 \\
\hline
\end{tabular}

Table XIX shows the average amount expended on each farm for hired labor, for each county in Utah, 1910(1). In Cache county an average of $\$ 217.48$ was expended as wages, rent, and board for hired help. This is about the same amount as was expended at Hyde Park in 1916.

Table XX shows the monthly and daily wages of farm labor, with and without board, in Utah from 1866 to 1918. By comparing the wages given in this table for farm labor and the wages of farm laborers for the United States as a whole one finds that on the average they are higher in Utah(2).

(1) 1910 U. S. Census,

(2) U. S, D. A, Monthly Crop Report, (Dec,, 1918), p. 146. 
Table XX.-Wages of Farm Labor in Utah(1), 1866-1918

\begin{tabular}{|c|c|c|c|c|c|c|}
\hline \multirow[t]{2}{*}{ Year } & \multicolumn{2}{|c|}{$\begin{array}{l}\text { Average Monthly } \\
\text { Wages for Year } \\
\text { or Season }\end{array}$} & \multicolumn{2}{|c|}{$\begin{array}{l}\text { Average Daily } \\
\text { Wages in } \\
\text { Harvest }\end{array}$} & \multicolumn{2}{|c|}{$\begin{array}{l}\text { Average Daily } \\
\text { Wages Other } \\
\text { Than Harvest }\end{array}$} \\
\hline & $\mid \begin{array}{c}\text { Without } \\
\text { Board }\end{array}$ & $\begin{array}{l}\text { With } \\
\text { Board }\end{array}$ & $\begin{array}{c}\text { Without } \\
\text { Board }\end{array}$ & $\begin{array}{l}\text { With } \\
\text { Board }\end{array}$ & $\begin{array}{c}\text { Without } \\
\text { Board }\end{array}$ & $\begin{array}{l}\text { With } \\
\text { Board }\end{array}$ \\
\hline $1966 \ldots . .$. & $\$ 44.71$ & $\$ 26.32$ & $\$ 3.42$ & $\$ 2.49$ & $\$ 2.27$ & $\$ 1.63$ \\
\hline 1875 & 35.50 & 25.33 & 2.20 & 1.75 & 1.80 & 1.40 \\
\hline 3879 & 28.87 & 20.50 & 1.82 & 1.43 & 1.46 & 1.12 \\
\hline $1882 \ldots$ & & & & & 1.57 & 1.10 \\
\hline $1885 \ldots$ & 30.00 & 21.00 & 2.00 & 1.56 & 1.52 & 1.14 \\
\hline 1888 & 33.50 & 22.30 & 1.75 & 1.36 & 1.42 & 1.10 \\
\hline $1890 \ldots$ & 32.30 & 21.00 & 1.72 & 1.30 & 1.38 & 1.05 \\
\hline 1892 & 33.50 & 22.30 & 1.70 & 1.27 & 1.40 & 1.08 \\
\hline $1893 \ldots$. & 33.29 & 24.65 & 1.80 & 1.43 & 1.28 & 1.06 \\
\hline $1894 \ldots \ldots \ldots \ldots$ & 29.98 & 21.16 & 1.48 & 1.22 & 1.14 & .92 \\
\hline $1895 \ldots . .$. & 29.81 & 21.00 & 1.32 & 1.07 & 1.18 & .90 \\
\hline $1898 \ldots \ldots \ldots$ & 32.97 & 24.41 & 1.34 & 1.05 & 1.39 & 1.10 \\
\hline 1899 & 34.43 & 25.72 & 1.57 & 1.29 & 1.48 & 1.22 \\
\hline $1902 \ldots$ & $37.99^{\circ}$ & 29.45 & 1.64 & 1.36 & 1.61 & 1.28 \\
\hline $1909(2) \ldots \ldots$ & 56.12 & 40.77 & 1.92 & 1.52 & & 1.61 \\
\hline $1910(3) \ldots \ldots \ldots$ & 47.50 & 35.00 & 2.20 & 1.78 & 2.00 & 1.55 \\
\hline $1917(3) \ldots \ldots$ & 68.00 & 50.00 & 3.25 & 2.73 & 3.00 & 2.42 \\
\hline $1918(3) \ldots . .$. & 84.00 & 64.00 & 3.80 & 3.15 & 3.50 & 2.60 \\
\hline
\end{tabular}

In 1909 ten per cent of the male outdoor laborers on farms, hired at a monthly rate, were hired by the year $(2)$.

Table XXI shows the ratio of agricultural workers to the improved area in farms $(2), 1880,1890,1900$, and 1910 .

Table XXI.-Ratio of Agricultural Workers to Improved Area of Farms 1880, 1890, 1900 and 1910 , Utah

\begin{tabular}{l|c|c|c}
\hline \hline Year & $\begin{array}{c}\text { Average } \\
\text { Improved } \\
\text { Acres } \\
\text { (Per Farm) }\end{array}$ & $\begin{array}{c}\text { Persons 10 Years } \\
\text { Old and Over, } \\
\text { Gainfully En- } \\
\text { gaged in Agri- } \\
\text { culture } \\
\text { (Per Farm) }\end{array}$ & $\begin{array}{c}\text { Acres of Improved Land } \\
\text { per Person 10 Years Old } \\
\text { and Over, Gainfully En- } \\
\text { gaged in Agriculture }\end{array}$ \\
\hline 1880 & 44 & 1.6 & 28.6 \\
1890 & 52 & 1.9 & 27.4 \\
1900 & 53 & 1.6 & 35.3 \\
$1909(4)$ & 63 & 1.7 & 37.4 \\
\hline
\end{tabular}

It should be noted that there are on the average about the same number of men on each Hyde Park farm, as there are persons 10 years old and over gainfully engaged in agriculture in the State. There are about the same number of crop-acres to the man on the Hyde Park

(1) U. S. D. A., Bureau of Statistics, Mise. Series, Bul, No, 26, (1903). pp. $14-22$. 1912)

(2) U. S. D. A., Bureau of Statisties, Misc. Series, Bul. No. 94, (Nov.,

(3) U. S. D. A., Monthly Crop Report, (Dec., 1918).

(4) 1910 , U. S. Census. 
farms as there are acres of improved land to each person 10 years old and over gainfully engaged in agriculture in the State.

Markets.- Markets for farm products affect the type of farming. ith is not advantageously situated with respect to world markets. It is a great distance to the central farm produce markets of the United States. Comparison of Utah farm prices with the average farm prices of the United States (1) as a whole, for the three ten-year periods, 1880-1889, $1890-1899$, and $1900-1909$, shows that hay, wheat, barley, sugar-beets, and potatoes are lower in price in Utah; and that the prices of corn. oats, and rye are higher in Utah. The prices varied as follows: hay, $\$ 1.50$ to $\$ 2.25$ per ton less, wheat 2 to 6 cents per bushel less, barley 0 to 5 cents per bushel less, sugar-beets 5 cents to $\$ 2.50$ per ton less, and potatoes 6 to 8 cents per bushel less, in Utah than in the United States as a whole; and corn 16 to 30 cents per bushel higher, oats 10 to 15 cents per bushel higher, and rye 0 to 2 cents per bushel higher in Utah than the average for the entire country (See Table XXIX in Appendix).

In general, the farm price is low for those products exported and high for those products imported; or, prices are low for products that are abundant and high for products that are scarce in relation to the local demand.

Where the market cannot be adanted to the type of farming otherwise best for an arca, the type of farming must be adapted to the market.

Most of the very perishable products such as fruits and vegetables must be consumed near home and therefore have a limited market (2). Not only is our fruit-haul to market a long one but Utah peaches come on the market in competition with those of southern Michigan. The Michigan peaches have a decided advantage because they do not have to stand the costs of long transportation. In recent years the canning of many of these perishables has widened the market for them. This is especially true of tomatoes and peas. As a result of this wider market. more tomatoes and peas are grown on Utah farms.

The milk market has been widened as a result of the development of condensed milk factories, creameries, and cheese factories. Because of this wider market more dairy cows are kept on farms. The surplus milk from Hyde Park farms is usually marketed at one of three places: (1) the branch factory of the Utah Condensed Milk Company, at Smithfield. (2) Borden's Condensed Milk Factory, at Logan, or (3) the Utah Agricultural College Creamery, at Logan.

Early each morning large milk wagons gather the milk cans from the homes about town. They deliver the milk to the factories and return with the cans, butter, and, if the milk is sent to a creamery, skim milk. These are left at the homes about $2: 00 \mathrm{p}, \mathrm{m}$. Some farmers have cream separators and usually send only cream to the creamery. After the cans are emptied at the factories they are washed and steamed before they are put back on the wagons. A regular rate for each hundred pounds or for each can of milk is charged for hauling. This cost is usually deducted from the farmers' milk checks at the factories and paid directly to the milk haulers.

In the past the meat animals have been shipped to the great meatpacking centers. At present most of the hogs and some sheep and cattle are marketed to advantage at Salt Lake City and Ogden, where packing plants are now in operation.

Hay, a very bulky product, has been shipped as far as Omaha and Kansas City, and often as far as Butte, Montana. There is not much

(1) U. S. D. A. Yearbook, 1917, Dec. 1, Farm Prices from 1880 to 1917. U. S. D. A. Bu. of Stat. Bul. No. 94, (Nov., 1912).

(2) Connor, L. G., U. S. D. A. Bul. No. 582 (1918), pp. 35-36. 
shipped out of the State at present and because of the limited agricultural area of the State it is probable that hay as well as some other agricultural products will be imported in considerable quantities in the near future. Most of the Hyde Park hay is consumed at Hyde Park, Logan and Smithfield.

The sugar-beets are unloaded from the farmers' wagons onto cars or at the beet-dump at Hyde Park spur. From here they are shipped to the sugar factory at Logan, the erection of which made it possible for the farmers of this area to grow sugar-beets as a cash crop. The farmers are thus dependent upon the factory for a cash market, and in turn the factory is dependent upon the farmers for the beets. Potatoes are usually not grown in large commercial quantities at Hyde Park. Most of them are marketed either at Hyde Park or hauled to Logan or Smith field.

Small-grains are easily shipped great distances to central markets and the Hyde Park grain is hauled to the Logan mills, to the Smithfield mills, or to the Hyde Park Spur and shipped to other markets. Each farmer's convenience and bargaining determine his methods of marketing.

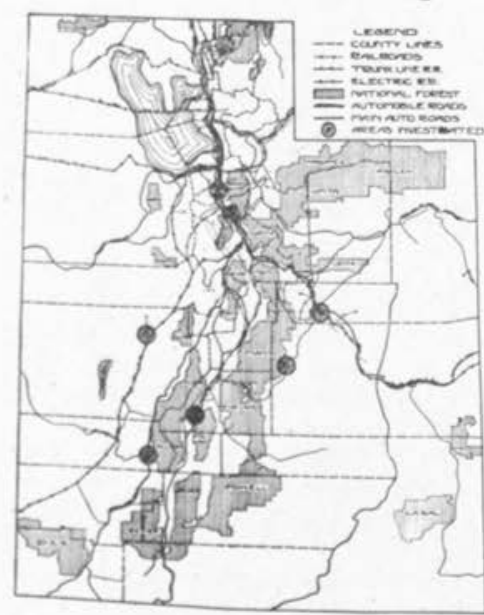

Fig. 20.-Railroads, Auto Roads, and National Forests, Utah. (after Clayson's Guide Map)

Wagon and Auto Roads and Railroads. - The State Road, which is the main auto road running north and south, passes thru the western part of Hyde Park Township and in general divides the meadow and pasture land on the west from the sugar-beet and potato land on the east. The center of the town of Hyde Park is situated about $1 / 2$ mile east of this State Road. The Utah-Idaho Central Electric Railroad passes thru the center of town. The Hyde Park Spur is $1 \frac{1}{2}$ miles west from town on the Cache Valley Branch of the Oregon Short Line Railroad. Such markets as are available, are accessible to Hyde Park farmers by good wagon and auto roads and railroads. The fact that Hyde Park is on a branch line of the Oregon Short Line Railroad is a handicap in shipping to distant markets. (See Figure 20.)

Land Tenure.-By land tenure is meant the relationship of the farmers to the land which they operate. Land tenure is inseparably connected with type of farming(1). At Hyde Park most of the land which is now irrigated has been under cultivation for from 40 to 60 years. During the last 20 years the bench land east of town has been developed by dry-farming methods. The farm buildings are all in town where the farm families live. The farms in this area include, (1) dry-farm land on the bench, (2) irrigated land for cultivated crops west of the bench land, and (3) still farther west towards the center of the valley, meadow and pasture land. Most of the farms include some of each of these three distinct types of land. This condition makes possible a greater diversity of farm business on these farms and is one of the factors contributing to the prosperity of the area.

None of the 52 farms of which records were obtained in 1914 were

(1) Hibbard, B. H., "Tenancy in the United States", in Carver's "Readings in Rural Economics", pp. 498 to 546 ; and Holmes, G. K., Ibid pp. 487 to 497 , "Tenancy in the United States". 
renant farms, but 23 of the 52 owners rented additional land, 18 paying cash rent for it, 3 renting on shares, and 2 paying cash for pasture and hay land and a share of the crop for the cultivated land. This is umusual because in Cache County generally share tenancy is most common. It must be remembered. however, that these farmers are not tenants but owners renting additional pieces of land. Since they have money to pay the cash for rent it is to their advantage to do so, for thus they get all of the produce. There were 184.5 acres rented for ash, for which $\$ 1,685$ was paid, or an average of $\$ 9.13$ per acre. Pasure rent was about $\$ 2$ to $\$ 3$ per acre and cultivated crop land ranged from $\$ 7$ to $\$ 21$ per acre, the latter being paid for an unusually good piece of sugar-beet land. Twenty-one acres was the largest piece of this irrigated land rented for cash. One piece of 360 acres of dry-farm land was rented for $\$ 860$ eash. Two other pieces of dry-farm land amounting to $25 \mathrm{~s}$ acres were rented on shares, the tenants getting sixtenths of the wheat crop. One piece of 128 acres of irrigated land was rented on shares. The tenant received one-half the hay and oats raised on the piece. Two other pieces were rented and the tenant received a trifle more than half the wheat in the one case and five-ninths of the alfalfa in the other. One young man had the use of 5 acres of his father's land and had all the crop. Another farmer, in addition to his own land, managed the family estate. He kept his aged mother and father and had all that he made from the estate. (See Tables III in Text and $\mathrm{XXX}$ in Appendix).

In 1914 the personal and property taxes amount to about 0.6 per cent and the water taxes amounted to about 0.2 per cent of the total farm capital investment. As a general rule the landlord or owner of the rented land or water pays the taxes. Land and water may be rented separately or together. (See Table XXX in Appendix).

On the average the 52 Hyde Park farmers have been owners of farms 20.7 years, and owners of the farms which they now operate 18.5 years. Those who have rented land at all have been tenants on the average for 4.7 years, and on the average they have been tenants of the land which they now rent in addition to their own land for 3.6 years. The land is rented for the purpose of increasing the size of the business and no doubt here as elsewhere is an intermediate step in the process of becoming owners of the land operated.

The small percentage of tenancy here is due to a number of circumstances and conditions. The country is new and it has been easy to become a farm owner without tenancy, by (1) homesteading or (2) purchasing. The farms are comparatively small and therefore the total capital necessary to purchase a farm is not so great as to make purchasing prohibitive to those who are moderately well-to-do. The type of farming followed is one that is conducive to ownership and compared with the farming of the North Central States is less attractive to tenants and less adaptable to tenant farming. Land has increased enormously in value. This has been a great incentive to farmers to own their own farms. These facts largely account for the present low percentage of tenant farmers at Hyde Park as well as in Cache County and the State.

In $1910(1)$ the approximate total land area of Cache County was 744,960 acres, 294,160 acres in farms, 181,348 acres improved land in farms, 5,779 acres of woodland in farms, 107,033 acres of other unimproved land in farms, and 450,800 acres of land not in farms. Thus 40 per cent of the land was in farms in 1910 and 62 per cent of this farm land was improved. There were 1,907 farms in the county with an average of 154.3 acres per farm, of which 95.1 acres were improved.

(1) 1910 U. S. Census. 
As late as July 1,1918 , there were still 239,918 acres of land in the county unappropriated and unreserved, of which 12,381 acres were surveyed and 227,537 acres were unsurveyed(1).

Of the $52,597,760$ acres of land in Utah(2), $31,475,919$ acres, or 60 per cent, were unappropriated and unreserved on July 1, $1918\left(^{1}\right)$. This land is described as "generally arid, agricultural, mineral, grazing, and mountainous." of this amount, $14,010,343$ acres were surveyed and $17,465,576$ acres were unsurveyed.

In the 9 years from 1909 to July 1,1918 , there were in Utah $5,175,143$ acres of public land entered for settlement. This is an average of 575,016 acres each year. In $1910(2)$ there were only $3,397,699$ acres in farms in the State and $1,368,211$ acres of farm land improved. In the 9 years, 1910 to July $1,1918(1)$ there was 69 per cent more land entered for settlement than there was land in farms, and more than four'times as many acres as there was improved land in farms, April 15, 1910 .

Of the $284,028,210$ acres of unappropriated and unreserved lands of the 11 far Western Range States, July 1, 1914, it is estimated that only 12 per cent, or $34,080,000$ acres were suitable for agricultural settlement under the then existing laws(3). Since July 1, 1914, three amendments to the Desert Land Laws $\left.{ }^{4}\right)$ have been passed and the Stock-Raising Homesteads-Act of December 29, 1916(5) has become operative. Undoubtedly these laws have made it practicable to settle more of this land than it was wise to settle before their enactment.

Table XXII shows the number of farms, the average size of farm, and the relationship of the farmers to the land which they operate Cache County, Utah, $1880,1890,1900$, and 1910.

Table XXII.-Tenure of Farms, Cache County, Utah, $1880,1890,1900$, and $1910(2)$

\begin{tabular}{|c|c|c|c|c|c|c|c|c|}
\hline \multirow{3}{*}{ Year } & \multirow{3}{*}{$\begin{array}{l}\text { Number } \\
\text { of } \\
\text { Farms }\end{array}$} & \multirow{3}{*}{$\begin{array}{c}\text { Average } \\
\text { Size } \\
\text { (Acres) }\end{array}$} & \multicolumn{4}{|c|}{ Number Farms Operated by } & \multirow{2}{*}{\multicolumn{2}{|c|}{$\begin{array}{c}\text { Percentage of } \\
\text { Farms Op- } \\
\text { erated by }\end{array}$}} \\
\hline & & & \multirow[b]{2}{*}{ Owners } & \multirow{2}{*}{$\begin{array}{l}\text { Part } \\
\text { Own- } \\
\text { ers }\end{array}$} & \multirow{2}{*}{$\begin{array}{c}\text { Own- } \\
\text { ers } \\
\text { and } \\
\text { Ten- } \\
\text { ants }\end{array}$} & \multirow[b]{2}{*}{$\begin{array}{l}\text { Man- } \\
\text { agers }\end{array}$} & & \\
\hline & & & & & & & $\begin{array}{l}\text { Own- } \\
\text { ers }\end{array}$ & $\begin{array}{l}\text { Ten- } \\
\text { ants }\end{array}$ \\
\hline $1880 \ldots$ & 998 & 85 & 943 & $\cdots$ & $\ldots$. & .... & 94.5 & 5.5 \\
\hline \890.. & 1,065 & 94 & 979 & & .... & .... & 91.9 & 8.1 \\
\hline $1900 \ldots$ & 1,795 & 176.4 & 1,446 & 236 & 6 & 16 & 80.6 & 5.1 \\
\hline $1910 \ldots$ & 1,907 & 154.3 & 1,756 & ...... & $\ldots$. & 12 & 92.1 & 7.3 \\
\hline
\end{tabular}

Over 92 per cent of the farms were operated by the owners in 1910 and only 7.3 per cent by tenants. Tenancy does not seem to be increasing in twe County. The figures show a smaller percentage of the farms operated by owners in 1910 than in 1880 , but a greater percentage of them operated by tenants in 1890 than in 1910 . Share tenancy always has been and is now the most common form. (See Table XXIII.)

(1) U. S. D. I., G. L. O., Cir. No. 608, (July, 1918).

(2) 1910 U. S. Census.

(3) U. S. D. A., Off. of Sec. Rpt. No. 110, Part II, (July 1, 1916), pp. $17-18$.

(4) U. S. D. I., G. L. O. Cir. No. 474, (May 18,1916$)$.

(5) U. S. D. I., G. L. O. Cir. No. 523, (Jan. 27, 1917). 
Table XXIII, - Number and Kinds of Tenants, Cache County, Utah, $1880,1890,1900$, and $1910(1)$

\begin{tabular}{l|r|c|c|c|c}
\hline \multirow{2}{*}{ Your } & \multicolumn{5}{|c}{ Number and Kinds of Tenants } \\
\cline { 2 - 6 } & Total & Share & Cash & Share and Cash & Not Specified \\
\hline 1850 & 55 & 33 & 22 & $\ldots$. & $\ldots$. \\
1890 & 86 & 55 & 31 & $\ldots$. & $\ldots$. \\
1900 & 91 & 76 & 15 & $\ldots$ & 34 \\
\hline 1910 & 139 & 59 & 35 & 11 & $3 .$. \\
\hline
\end{tabular}

The explanation of conditions as found in Table XXIII is the same as that given for the conditions at Hyde Park.

Table XXIV shows the total area, area in farms, and the area of farm land improved in the State, and in each county, arranged according to the acres of improved farm land, 1909. Cache County had the greatest and Grand County the smallest area improved.

Table XXIV.-Total Land Area, Land in Farms, and Improved Land in Farms, by Counties, Utah, 1909 (1)

\begin{tabular}{|c|c|c|c|}
\hline & \multicolumn{3}{|c|}{ Acres } \\
\hline & $\begin{array}{c}\text { Improved lanó } \\
\text { in farms }\end{array}$ & $\begin{array}{l}\text { All land in } \\
\text { farms }\end{array}$ & $\begin{array}{l}\text { Total } \\
\text { area }\end{array}$ \\
\hline State $\ldots \ldots \ldots \ldots \ldots \ldots \ldots \ldots \ldots \ldots$ & $1,368,211$ & $3,397,699$ & $52,597,760$ \\
\hline County & & & \\
\hline 1. Cache .. & 181,348 & 294,160 & 744,960 \\
\hline 2. Boxelder & 142,922 & 343,185 & $3,484,160$ \\
\hline 3. Utah ......... & 124,496 & 234,717 & $1,301,760$ \\
\hline 4. Salt Lake.. & 121,221 & 169,262 & 483,840 \\
\hline 5. Sanpete ......... & 105,807 & 261,771 & $1,000,960$ \\
\hline 6. Rich ..... & 81,779 & 149,509 & 657,280 \\
\hline 7. Weber & 59,781 & 148,359 & 346,240 \\
\hline 8. Sevier ....... & 56,338 & 122,332 & $1,265,920$ \\
\hline 9. Davis & 55,376 & 127,257 & 176,000 \\
\hline 10. Millard & 54,540 & 166,627 & $4,226,560$ \\
\hline 11. Juab .............. & 53,466 & 108,564 & $2,182,400$ \\
\hline 12. Wasatch & 43,220 & 154,083 & $2,786,560$ \\
\hline 13. Emery ... & 39,386 & 96,708 & $2,849,920$ \\
\hline 14. Uinta... & 35,748 & 82,072 & $3,350,400$ \\
\hline 15. Tooele & 34,239 & 88,332 & $4,383,360$ \\
\hline 16. Summit .......................... & 32,645 & 261,056 & $1,191,680$ \\
\hline 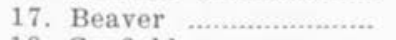 & 19,354 & 35,986 & $1,702,400$ \\
\hline 18. Garfield .......................... & 19,109 & 59,973 & $3,349,760$ \\
\hline 19. Iron & 17,934 & 88,027 & $2,083,840$ \\
\hline 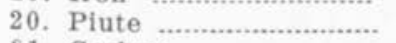 & 16,964 & 25,869 & 488,320 \\
\hline 21. Carbon & 13,824 & 56,653 & 951,680 \\
\hline 22. Washington .................... & 13,632 & 50,273 & $1,577,600$ \\
\hline 23. Morgan & 11,691 & 95,648 & 400,640 \\
\hline 24. Wayne & 11,538 & 31,617 & $1,584,000$ \\
\hline 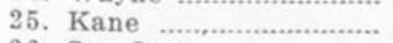 & 8,685 & 24,773 & $2,697,600$ \\
\hline 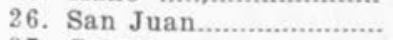 & 6,698 & 48,797 & $4,967,040$ \\
\hline 27. Grand & 6,470 & 62,089 & $2,362,880$ \\
\hline
\end{tabular}

(1) 1910 U. S. Census. 
Table XXV shows the percentage of all farms operated by the owners, part owners, and tenants in Utah, $1880,1890,1900$, and 1910 ss given by the U. S. Census Reports.

Table XXV.-Percentage of Tenancy, Utah, 1880-1910

\begin{tabular}{l|c|c|c}
\hline \hline \multirow{2}{*}{ Year } & \multicolumn{3}{|c}{ Per cent of all Farms Operated by } \\
\cline { 2 - 4 } & Managers & Owners and Part Owners & Tenants \\
\cline { 2 - 4 } & $\ldots . .$. & 95.4 & 4.6 \\
1890 & 1.6 & 94.8 & 5.2 \\
1900 & .9 & 89.6 & 8.8 \\
1910 & 91.2 & 7.9 \\
\hline
\end{tabular}

The explanation of the tenancy conditions of the State as shown in Table XXV is the same as that of the conditions at Hyde Park. (See Tables XXXI to XXXVI in Appendix).

Land Values.-Land values are largely determined by type of farming. The agricultural value of a piece of land is the capitalized agricultural income of that land with all future inereases discounted to date; and the income of the land is obviously a result of the type of farming practised (1).

The individual farmer must follow a type of farming that is profitable on land of a given value. Land which can be rented profitably for $\$ 20$ an acre for producing sugar-beets will not be rented for $\$ 3$ an acre and used for pasture, except in unusual and rare cases. The value of the land will be based upon the $\$ 20$ and not the $\$ 3$. And as long as there are men who want the land for sugar-beets and can afford to pay $\$ 20$ an acre for it, other men as a rule will not be so unwise, for any length of time, as to pay $\$ 20$ for such land and use it as pasture when such use will not be profitable for any rent above $\$ 3$.

The factors affecting land values are too numerous to mention here. Only a general analysis is given. Before 1847 land in Utah had little

Table XXVI. - Total Value of Land and Buildings, and Value of Land and Buildings per Farm and per Acre, 52 Farms,

Hyde Park, Cache County, Utah, 1914

Total Acres in all 52 Farms.

5,434

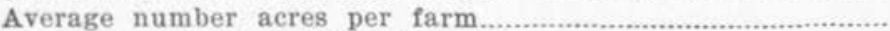

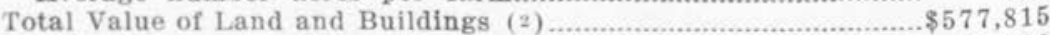

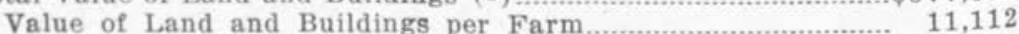

Value of Land and Buildings per Acre..................................... 106

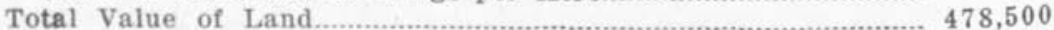

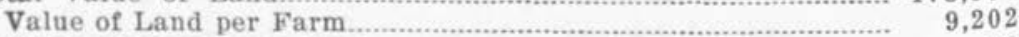

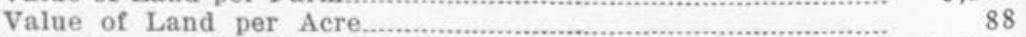

Total Value of Buildings............................................................... 99,315

Value of all Buildings per Farm (in Town) ........................ 1,910

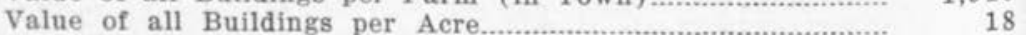

Value of Dwellings per Farm (2) ............................................ $\quad 1,284$

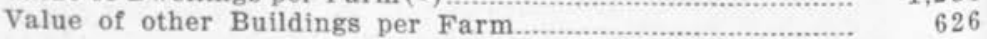

(1)Taylor, H. C.-Agricultural Economics, (1914), ch. 10, pp. 185-197, Macmillan Co., N. Y.

(2) Reports on the value of dwellings were obtained from 50 farms only. The average value of dwellings for the 50 farms reporting was $\$ 1,335$. 
o: no agricultural value. Such as it might have had was based upon its prospective future use. As the State became populated, land came to have a value based upon its productivity. This value increased as population became more dense and the land more developed and improved.

Comparison of Hyde Park values as given in Table XXVI with those for Cache County and the State, given in Tables XXVIII, XXIX and XXX shows this area to be much better than the average. It has been settled longer and is more developed than many sections of the state.

It is impossible to show from the records obtained the changes in land values at Hyde Park. The 1915 and 1916 farm values were raised or lowered by the farmers as determined more by the accuracy of their 1914 estimate than by the actual changes in the market value of the land.

Table XXVII was made in order to determine the correlation between distance to market and the value of farm land per acre in each of the 7 districts in which farm business records were taken in 1914.

Table XXVII.-Distance from Market and Land Values per Acre in 7 Areas, Utah, 1914

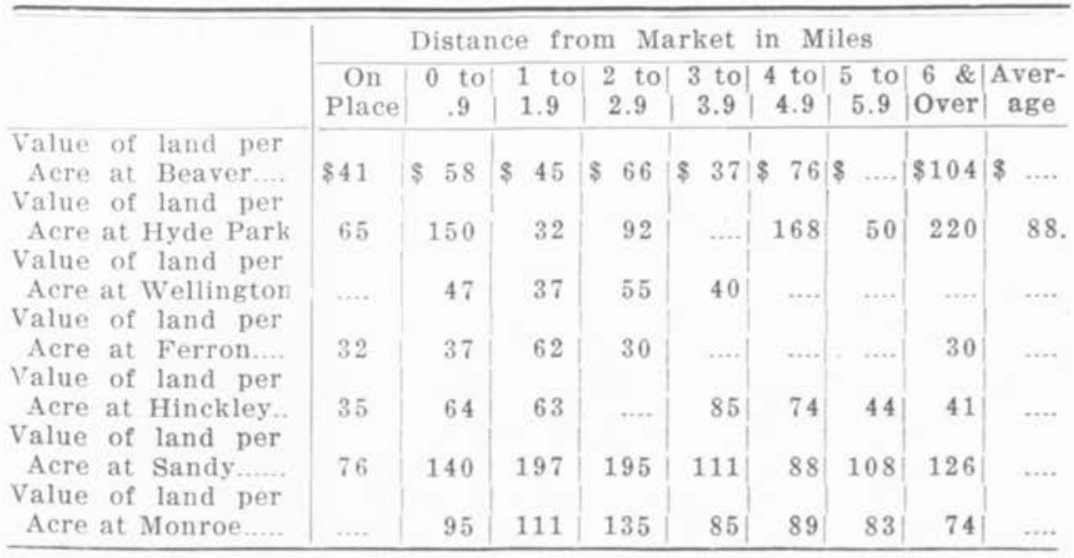

There seems to be no correlation between distance to market and value of land per acre as given in Table XXVII. The difficulty is that other factors are more important, and therefore the correlation which undoubtedly exists is not visible. Those farms nearest to market have an advantage in marketing. Land values are certain to be high there because of this advantage. The average value of land per acre at Hyde Park in 1914 was $\$ 88$. This is $\$ 50$ higher than the average value for Cache County and $\$ 59$ higher than the average value of land in the State in 1910. At Hyde Park farm products are readily marketed as explained in a previous paragraph. Consequently better soil may offset easily the advantage of nearness to market. The fact that there are too few farms in the groups makes Table XXVII of little value except in indicating the method of observation.

Table XXVIII shows the percentage of land in farms and farm land improved and land value per acre, by counties, for Utah on April 15 , 1910. The counties are arranged according to the percentage of farm land improved. 
Table XXVIII.-Percentage of Land in Farms and Farm Land Improved and Land Value per Acre, by Counties, Utah, 1910(1)

\begin{tabular}{|c|c|c|c|}
\hline & \multicolumn{2}{|c|}{ Percentage of } & \multirow{2}{*}{$\begin{array}{c}\text { Land Value } \\
\text { per Acre }\end{array}$} \\
\hline & $\begin{array}{l}\text { Farm Land } \\
\text { Improved }\end{array}$ & $\begin{array}{l}\text { Land Area } \\
\text { in Farms }\end{array}$ & \\
\hline State .............................. & 40.3 & 6.5 & $\$ 29.28$ \\
\hline County & & & \\
\hline 1. Salt Lake..................... & 71.6 & 35.0 & 78.34 \\
\hline 2. Piute ............................. & 65.6 & 5.3 & 23.51 \\
\hline 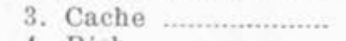 & 61.6 & 39.5 & 37.85 \\
\hline 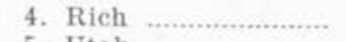 & 54.7 & 22.7 & 9.32 \\
\hline 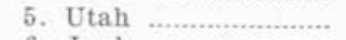 & 53.0 & 18.0 & 58.27 \\
\hline 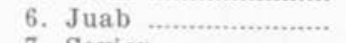 & 49.3 & 5.0 & 18.95 \\
\hline 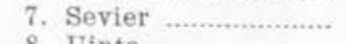 & 46.1 & 9.7 & 32.67 \\
\hline 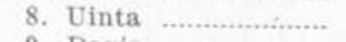 & 43.6 & - 2.4 & 25.89 \\
\hline 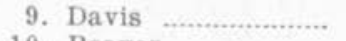 & 43.5 & 72.3 & 61.41 \\
\hline 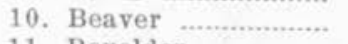 & 42.1 & 2.7 & 25.33 \\
\hline 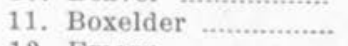 & 41.6 & 9.8 & 28.25 \\
\hline 12. Emery .......................... & 40.7 & 3.4 & 26.75 \\
\hline 13. Sanpete ..................... & 40.4 & 26.2 & 19.91 \\
\hline 14. Weber & 40.3 & 42.8 & 50.55 \\
\hline 15. Tooele .......................... & 38.8 & 2.0 & 24.80 \\
\hline 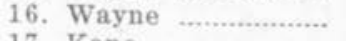 & 36.5 & 2.0 & 12.91 \\
\hline 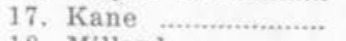 & 35.1 & 0.9 & 11.45 \\
\hline 18. Millard ...................... & 32.7 & 3.9 & 18.51 \\
\hline 19. Garfield ...................... & 31.9 & 1.8 & 11.87 \\
\hline 20. Wasateh ....................... & 28.1 & 5.5 & 17.86 \\
\hline 21. Washington ............ & 27.1 & 3.2 & 18.39 \\
\hline 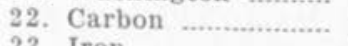 & 24.4 & 6.0 & 15.05 \\
\hline 23. Iron ......................... & 20.4 & 4.2 & 13.37 \\
\hline 24. San Juan.................... & 13.7 & 1.0 & 10.99 \\
\hline 25. Summit ........................ & 12.5 & 21.9 & 7.71 \\
\hline 26. Morgan ..................... & 12.2 & 23.9 & 12.32 \\
\hline 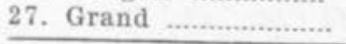 & 10.4 & 2.6 & 18.42 \\
\hline
\end{tabular}

In constructing Table XXIX the 27 counties or the State were divided in four groups according to the percentage of farm land improved. This table shows that there is a correlation as expected between the use

Table XXIX.-Relation of Improved Farm Land to Value of All Farm Land Per Acre, Utah, 1910 (1)

\begin{tabular}{c|c|c|c|c}
\hline Group (2) & $\begin{array}{c}\text { No. } \\
\text { Coun- } \\
\text { ties }\end{array}$ & $\begin{array}{c}\text { Percentage of } \\
\text { Farm Land } \\
\text { Improved } \\
\text { (Average) }\end{array}$ & $\begin{array}{c}\text { Percentage of } \\
\text { Land Area } \\
\text { in Farms } \\
\text { (Average) }\end{array}$ & $\begin{array}{c}\text { Value of all } \\
\text { Land } \\
\text { Per Acre } \\
\text { (Average) }\end{array}$ \\
\hline $1 \ldots \ldots . .$. & 7 & 57.4 & 19.3 & $\$ 36.99$ \\
\hline & 7 & 41.7 & 22.8 & 34.01 \\
\hline$\ldots . . . . . . .$. & 7 & 31.5 & 2.8 & 16.54 \\
\hline
\end{tabular}

(1) Adapted from 1910 U. S. Census, Supplement for Utah, Table 1, pp. 612-614.

(2) Groups are based upon percentage of farm land improved as shown in Table 25. Group 1 has the 7 counties with the greatest percentage and Group 4 the least percentage of farm land improved. 
of land and its value. In general, the value of farm land is highest in thos counties where the population is most dense and the greatest werentage of farm land is improved. (See Figure 19).

Tabl. $\times \times X$ shows the average values per acre of farm land, buildings, machinery, and livestock, by counties, Utah. April 15, $1910(1)$.

This table is useful in connection with this study in comparing the counties with each other and the average of the State.

Table XXI shows the average value of land and buildings per acre by counties. Utah, Census Years, 1860 to 1910.

Table XXX.-Average Values per Acre of Farm Land, Buildings, Machinery, and Livestock, by Counties, Utah(1), 1909

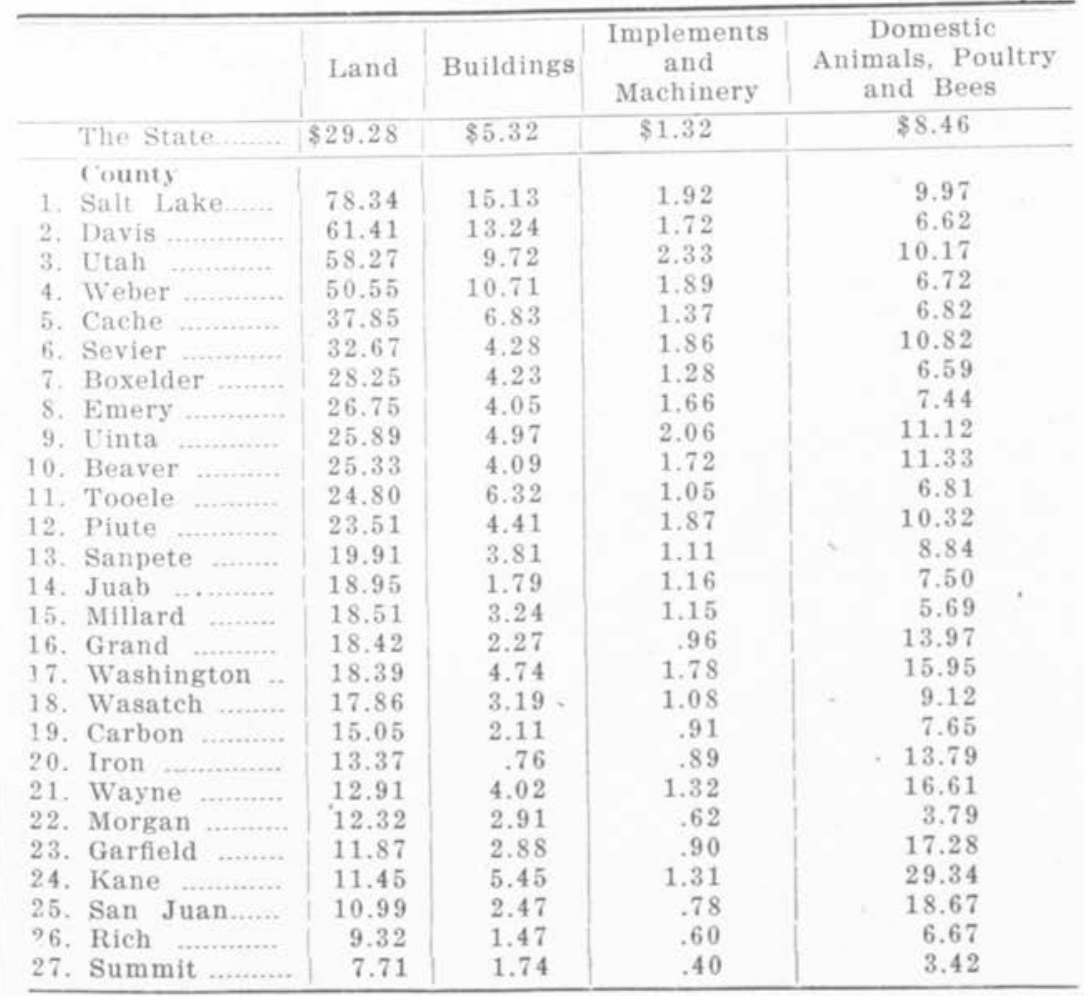

In general the value of land and buildings per acre has increased each successive census period. The value in 1900 shows a decrease because much grazing land of low value was included as farm land in the census of 1900 and this lowered greatly the average value of farm land per acre.

As population increases or the relative prices of farm products rise or interest rates become lower the land is more thoroughly and intensively utilized and land values become greater. Land values also rise when the relative value of the dollar decreases.

Water Tenure.-At Hyde Park about two-thirds of the crop land is irrigated and the other one-third is dry-farm land. Most of the Hyde

(1) 1910 U. S. Census 
Park land that can be irrigated is now irrigated. Either the water supply or the location of the land limits extension of the area. Above the Logan, Hyde Park, and Smithfield canal there is some bench land for which there is no water. This is now dry-farmed to good advantage.

Three canal systems from Logan River supply the irrigation water for Hyde Park: (1) Logan and Hyde Park Canal, (2) Logan and Richmond Canal, and (3) the Logan, Hyde Park and Smithfield Canal. (See Fig. 21.

Table XXXI.-Average Value of Land and Buildings per Acre, by Counties, Utah, Census Years

\begin{tabular}{|c|c|c|c|c|c|c|}
\hline & 1910 & 1900 & 1890 & 1880 & 1870 & 1860 \\
\hline State ................. & $\$ 34.60$ & $\$ 12.33$ & $\$ 21.46$ & $\$ 21.38$ & $\$ 15.49$ & $\$ 14.82$ \\
\hline Counties & & & & & & \\
\hline Beaver & 29.42 & 20.14 & 14.10 & 22.98 & 10.17 & 7.54 \\
\hline Boxelder & 32.48 & 5.52 & 5.53 & 17.90 & 11.80 & 17.96 \\
\hline Cache & 44.68 & 15.61 & 20.29 & 17.52 & 9.75 & 15.99 \\
\hline Carbon & 17.16 & 8.41 & & & & \\
\hline Davis .. & 74.65 & 16.71 & 35.44 & 20.20 & 40.45 & 28.02 \\
\hline Emery .. & 30.80 & 14.36 & 12.83 & 1.50 & & \\
\hline Garfield ........... & 14.75 & 13.09 & 15.17 & 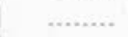 & & \\
\hline Grand & 20.69 & 20.68 & 14.41 & & & \\
\hline Iron $\ldots$ & 14.13 & 13.95 & 14.45 & 24.28 & 8.08 & 6.33 \\
\hline Juab ....... & 20.74 & 12.06 & 15.17 & 37.95 & 10.15 & 5.77 \\
\hline Kane .......... & 16.90 & 14.95 & 19.57 & 28.33 & 30.66 & \\
\hline Millard ... & 21.75 & 15.81 & 8.12 & 15.66 & 7.94 & \\
\hline Morgan .............. & 15.23 & 4.57 & 26.11 & 20.51 & 20.39 & \\
\hline Piute ....... & 27.92 & 11.22 & 10.55 & 2.76 & & \\
\hline 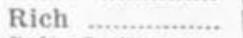 & 10.79 & 6.37 & 10.26 & 8.37 & 11.33 & \\
\hline Salt Lake......... & 93.47 & 30.80 & 82.11 & 37.66 & 35.24 & 17.01 \\
\hline San Juan.............. & 13.46 & 5.64 & 13.48 & 3.94 & & \\
\hline Sanpete .............. & 23.72 & 20.56 & 21.42 & 21.66 & 15.88 & 8.37 \\
\hline Sevier ................... & 36.95 & 22.03 & 15.49 & 9.42 & 8.42 & \\
\hline Summit & 9.45 & 5.06 & 20.36 & 11.02 & 4.28 & \\
\hline Tooele .............. & 31.12 & 10.67 & 23.02 & 24.19 & 42.35 & 20.28 \\
\hline Uinta & 30.86 & 3.38 & 17.13 & 2.33 & & \\
\hline 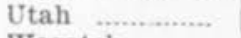 & 67.99 & 29.79 & 41.83 & 24.81 & 12.85 & 8.28 \\
\hline Wasatch .............. & 21.05 & 9.35 & 18.66 & 15.83 & 4.74 & \\
\hline Washington .... & 23.13 & 34.36 & 39.32 & 44.34 & 30.71 & 28.52 \\
\hline Wayne ................. & 16.93 & 9.56 & - & & & \\
\hline Weber ................. & 61.26 & 21.89 & 6.18 & 2.38 & 15.29 & 17.94 \\
\hline
\end{tabular}

Irrigation from the Logan River began in 1860. Soon afterward the Logan and Hyde Park canal was begun. In 1864 the Logan and Richmond Canal was begun. This latter canal now supplies water for land above or east of the Logan and Hyde Park Canal. The Logan and Richmond Canal was not completed until 1877 (1). Twice since then it has been enlarged. The Logan, Hyde Park, and Smithfield Canal made its first appropriation of water in 1882 (2). The first 7,000 feet of this canal is constructed on a steep mountain side necessitating considerable rock work, and its course is very much higher in elevation than either of the other canals. It shall therefore be referred to hereafter as the High Line Canal in contrast with the Upper and Lower Canals.

(1) Swenson, G. L.-U. S. D. A. Bul. No. 86 (1900), pp. 197-218.

(2) Swenson, G. L.-U. S. D. A. Bul. No. $104(1902)$, pp. 179-194. 
The Logan and Richmond Canal, or Upper Canal, supplies sufficient water on the average to irrigate about 3,186 acres and the Logan, Hyde Park, and Smithfield Canal, or High Line Canal, about 3,200 acres. The Lpper Canal system is owned and managed by the farmers organized as an irrigation company under the law passed in 1865 , and the High Line Canal system is owned and operated by the farmers organized as a stock ompany.

In both canals water-rights were obtained in payment for services in constructing them or bought from the original owners. In the Upper

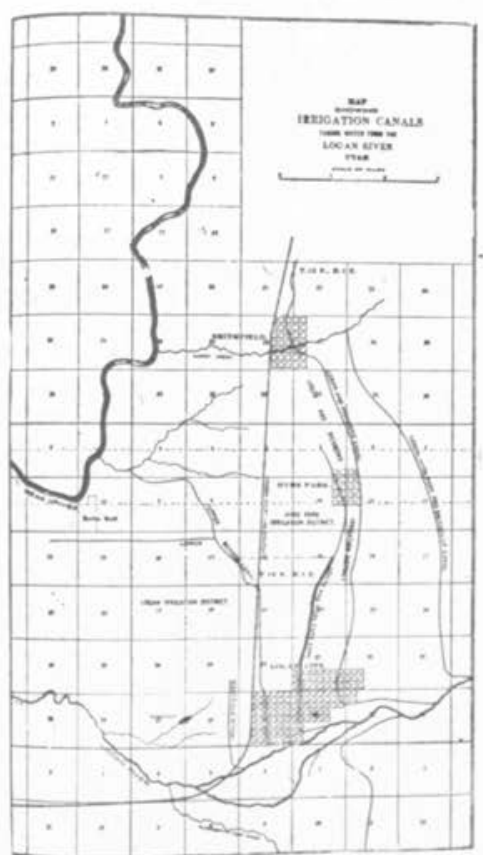

Fig. 21.-Three Canals that Supply Irrigation Water for Hyde Park Farms, Cache County, Utah. (after G. L. Swenson) Canal a water-right entitles one to sufficient water to irrigate a certain number of acres, a very variable and uncertain quantity; but in the High Line Canal a water-right entitles one to only his proportion of the available irrigation water, a more variable and uncertain amount; and the division is made on the basis of shares of stock held in the company. In neither case does the right specify an exact quantity of water. This lack of specification has advantages and disadvantages. However, it is impossible to discuss them here.

A claim to sufficient water to irrigate one acre cost the original owners of the Upper Canal $\$ 18$ to $\$ 20$ and about 50 cents annually per acre irrigated for operation and maintenance of the canal system. Only one-third of the 50 cents per acre charge is required in cash. The other two-thirds may be paid in labor. The original shares in the High Line Canal cost $\$ 5$ each and the annual maintenance and operation of the canal system cost about 50 cents per share.

The best way to express the duty of water is in inches or cubic feet per second when the water is not stored, but when the water is stored it is best expressed in acre-feet. It is better to express it in acre-feet per acre and not in a fraction of an acre per acre-foot. When a stream is discharging one cubic foot of water every second of time there is a second-foot flow. A second-foot stream discharges approximately one acre-inch per hour, one acre-foot in twelve hours, two acre-feet in twenty-four hours (one day), and two hundred forty acre-feet in the four months, May 1 to August 31, inclusive(1).

The duty of water under the High Line Canal was about sixty acres per cubic foot per second in 1900 , and the duty under the Upper Canal was about sixty-two acres per cubic foot per second including loss from seepage and evaporation from the canal and forty-seven acres not including this loss. The duty may be greatly increased by the time

(1) Winsor, L. M.-Utah Exp. Sta. Cir. No. 6 (1912); and Israelsen. O. W.-Utah Exp. Sta. Cir. No. 36 (1919). 
method of distribution under which each acre-right entitles the person to the use of an "irrigating stream" for a specified number of hours.

Water masters are elected by the owners of each system. These water masters have complete supervision over the water distribution. There are but few gauges or measuring devices, and headagate boxes are of variable sizes. Tho "irrigating streams" are supposed to be equal, they are not. The equivalent of an "irrigating stream," as measured, ranged from 0.85 to 3.12 cubic feet per second (1). The splendid success of these canals has been due to (1) the general spirit of cooperation among the water users, and (2) the type of men who have managed the distribution of the water.

A good irrigating stream for the average man under average conditions is from 2 to 5 second-feet (2). Three to five acre-inches is enough for a good irrigation. Two and one-half acre-feet is the maximum needed in Utah, in addition to the precipitation to produce a crop, if it is applied at the proper season between May 1 and August 31, inclusive. One second-foot will irrigate 70 to 160 acres in the four months of the irrigating season.

In Cache County, as in all parts of the State, water tenure, waterrights, and the operation and management of the canal systems are of prime importance. In $1910(3)$ there were 1,907 farms in Cache County, $1,501(4)$ or 79 per cent of which were irrigated. The approximate land area of the county was 744,960 acres. There were 294,160 acres in farms, 181,348 acres-not including wild grass land-improved, and 77,330 acres-including wild grass land-irrigated. The land irrigated was 10.4 per cent of the total land area, 26.3 per cent of the land in farms, and 42.6 per cent of the improved land in farms. In 1910 the irrigation enterprises were capable of irrigating only 82,503 acres, but 119,304 acres were included in the projects. There were 62,230 acres irrigated by cooperative enterprises(5). These same enterprises were capable of irrigating 63,767 acres and included 97,521 acres. The remainder of the land was irrigated under the following projects: irrigation districts( $\left(^{\circ}\right), 8,455$ acres; (2) individual and partnership enterprises( 7$), 5,623$ acres; and (3) commercial enterprises (8), 1,022

(1) Swenson, G. L.-U. S. D. A. Bul. No. 104 (1902), pp. 179-218.

(2) Winsor, L. M.-Utah Exp. Sta. Cir. No. 6 (1912).

(3) U. S. Census (1910)

(4) Ibid. - "The number of 'farms irrigated' is the number of farms on which irrigation is practised, and is equivalent to the term 'number of irrigators' which was used in previous census reports."

(5) Ibid.- "Cooperative enterprises are those which are controlled by the water users under some organized form of cooperation. The most common form of organization is the stock company, the stock of which is owned by the water users."

(6) U. S. Census (1910)- - Irrigation districts are public corporations that operate under state laws providing for their organization and management, and empowering them to issue bonds and levy and collect taxes with the object of obtaining funds for the purchase or construction, and for the operation and maintenance of irrigation works."

(7) Ibid.- "Individual partnership enterprises belong to individual farmers or to neighboring farmers, who control them without formal ship and cooperative enterprises, unimportant."

(s) Ibid.- "Commercial enterprises supply water for compensation to parties who own no interest in the works. Persons obtaining water from such enterprises are usually required to pay for the right to receive water, acreage irrigated a dion, annual charges based in some instances on the acreage irrigated and in others on the quantity of water received." 
aeres. The source of the water supply for irrigation was as follows: (1) streams, by gravity, 73,369 acres: (2) springs, 3.916 acres; and (3) llowing wells, 45 acres. There were 137 .independent irrigation nferprises having 139 main ditches, with a combined length of 324 miles and a combined capacity of 1,393 cubic feet per second. There were 153 laterals with a combined length of 142 miles. Other sources of water are: one reservoir, filled by collecting storm water or by a water course that is ordinarily dry, of 1,566 acre-feet capacity; and thirty-three flowing-wells of 734 gallons per minute capacity. The cost of all irrigation enterprises reporting costs, as reported by the 1910 census, up to July 1,1910 , was $\$ 304,285$. The average cost of construction per acre that enterprises were capable of irrigating in 1910 was \$3.69. The estimated final cost of existing enterprises was $\$ 304,285$. or an average of $\$ 2.55$ per acre included in the projects. The cost of operation and mantenance was reported for 63.507 acres and amounted to $\$ 26,974$, or an average of 42 cents per acre.

Water was formerly personal property in Utah(1) and rights were sold, exhanged, and leased with little regard for formalities-and often without making any official record of the transactions. Whe. a farmer found that his water-right furnished him more water than he needed. he sold a part of it outright. or rented a part of it by the year to some neighbor, or he bought another piece of land and transferred a part of his water-right to it. A ditch company could rent or sell a part of its rights te some other ditch company.

And even now not all the irrigators of Utah have definite, undisputed, legally defined titles to water. Often the seller does not know what he is selling, nor the buyer what he is buying. The water transferred is supposed to irrigate a certain number of acres. It may irrigate more or less, depending upon the available supply in the streams and upon how the water master divides it.

Only recently has any attempt been made to measure out any certain quantity of water. The water of but few of the streams is divided accurately. The records of water-rights are now entered in the office of the State Engineer who also issues all permits to appropriate water. The rights of appropriations now issued by the State Engineer state specifically in feet and inches the amount of water included, but it is a difficult task to determine how much water to allow permits for in the various streams because the volume of water in the streams varies greatly from year to year and from season to season. However, investigations and experience have given a body of quite accurate information for the most important streams of the State.

The foregoing discussion shows clearly how water tenure affects the type of irrigation farming. Water is almost as important in determining type of farming as land. While perhaps not more than 10 per cent of the land in Utah will ever be cultivated, yet if even this area is farmed profitably it will be possible only by irrigation.

Irrigation Practice. - On the farm lands at Hyde Park the custom is to use the water whenever and wherever it may be needed up to the limit of the supply. The average irrigating season is 110 to 120 days in May, June, July, August, and September. There are two methods of applying the water: (1) flooding the whole surface, used in irrigating (a) wheat, (b) oats, (c) alfalfa, (d) hay, (e) corn; and (f) orchards; and (2) the furrow method which is used in irrigating (a) sugar-beets, (b potatoes, (c) gardens, (d) orchards, and (e) corn.

Wheat, oats, corn, and hay are usually irrigated twice; sugar-beets, potatoes, alfalfa, and the other crops three or more times. The depth of

(1) Gemmell, R. C.-U. S. D. A. Bul. No. 104 (1902), pp. 159-163. 
irrigation water used varies greatly with crop and soil. In 1899 the average was about 3.59 feet(1). The total water received by the land was 3.59 feet by irrigation and 0.16 feet by rainfall, a total of 3.75 feet. The average depth applied at each irrigation in 1899 was 1.2 feet. In 1899 the greatest demand for water was for wheat and alfalfa and therefore came first in July and second in June. The demand in August and September was due to the late irrigations of alfalfa. At present little wheat is raised at Hyde Park by irrigation. The irrigation of alfalfa is about the same now as twenty years ago, but sugar-beets have taken the place of wheat as a cash crop on the irrigated land. The heavy irrigating seasons are now, as they were in 1899 , in July and June. Table XXXII shows the crops grown, the period of irrigation, the number of irrigations, and the days between irrigations, Hyde Park, Cache County, Utah, 1900.

Table XXXII.-Crops Grown, Period of Irrigation, Number of Irrigations, Days Between Irrigations, Logan and Richmond Canal, $1900(1)$

\begin{tabular}{|c|c|c|c|}
\hline Crop Grown & Period of Irrigation & $\begin{array}{l}\text { No. of } \\
\text { Irrigations }\end{array}$ & $\begin{array}{c}\text { Days Between } \\
\text { Irrigations }\end{array}$ \\
\hline Wheat... & June 1 to August $15 \ldots \ldots . . .$. & 2 & 21 \\
\hline Oats....... & June 15 to August $20 \ldots$. & 2 & 25 \\
\hline Alfalfa.. & June 6 to September $10 \ldots$ & 3 to 5 & 21 \\
\hline Potatoes......... & July 10 to August $29 \ldots \ldots$. & 4 to 6 & 20 \\
\hline Sugar-beets... & June 15 to September 20 . & 5 to 7 & 15 \\
\hline Gardens......... & June 1 to September 15 . & 7 to 15 & 7 \\
\hline Orchards... & June 1 to September 15. & 7 to 15 & 7 \\
\hline
\end{tabular}

The wheat and oats were irrigated twice. Twice as many irrigations were necessary for alfalfa as for the small-grains and about twice the amount of water was also applied, 2.90 feet as compared to 1.25 feet on oats where no waste occurs(1).

Quantity of Irrigation Water to Use(2). - Wheat requires relatively little water. On deep, well-tilled soils $7 \frac{1}{2}$. inches of water in two irrigations should be sufficient; on shallow, gravelly soils as high as 18 inches may be used in 4 or 5 irrigations. An average of one acre-foot should be ample for the production of wheat on fertile, well-tilled soils. Oats should not receive less water than wheat; barley about the same amount as wheat; but rye may be grown with less water than the other small-grains. Corn should seldom receive more than from 12 to 18 inches of water.

Alfalfa can make use of more water than the grains and should receive from 12 to 24 inches of water according to the age of the crop and the depth of the soil. Ordinarily, 18 inches should be enough. The other hay-making crops like timothy and orchard grass need even less water than a crop of wheat. They are cut only once, while alfalfa is cut three times or more. Clover requires probably from 12 to 15 inches of water. Pastures and meadows should receive according to location from 12 to 24 inches of water.

Under present practice sugar-beets receive from 15 to 24 inches of water, but the tendency is for somewhat less to be used. Carrots and other root crops should receive about the same. The more seed is planted the more water is required. Potatoes need a good supply of water in

(1) Swenson, G. L.-U. S. D. A. Bul. No. 104 (1902), pp. 179-218.

(2) Widtsoe, J. A., Stewart, Geo.- "Western Agriculture" (1918)
p. 138. Web. Pub. Co., St. Paul, Minn. 
the soil at flanting time. The total quantity should be about the same as that lot sugar-beets.

As a rrile cultivated crops on irrigated land require less water than uncultivatid props. Alfalfa requires more than potatoes and oats more than corn. It has been aptly said that "the limit of profitable economy (in irriguting), is to use the least quantity of water necessary to secure the best yield" (1). This is true if by "best yield" we mean the most profitable yield. The most profitable yield is not necessarily the highest yield.

It is fairly safe to say that all ordinary crops, including trees and shrubs, should receive from 12 to 24 inches of water. This amount is considerably less than is now applied to crops. As better cultural methods are employed the duty of water becomes higher, that is, less is used lier acre

When to Irrigate.-Investigations at Greenville, the township adjoining Hyde Park on the South, with conditions very similar in most respects to the Hyde Park area, show that about 20 inches of water may be recommended for use for the growing of corn for grain(2) and about 30 inches for growing corn stover (3). With sugar-beets, 1 inch of water weekly gives ligher yields than more than this amount. If only one irrigation is given the best time to apply it is when the beets are about 2 inches in diameter as this results in a higher percentage of sugar in the beet than when watered at any other time (4).

The highest yield of potatoes is produced where small regular irrigations are given. One inch weekly or 12.8 inches during the season gives a higher yield than any other treatment $(5)$. This involves a labor problem which complicates the irrigation practice. When as much as 96 inches of water are applied the yield is less than where no water is applied. Where but one irrigation is applied, it gives best results if applied when the potatoes are in full bloom. The second best stage is just as tubers begin to form. Discontinuing irrigation during the rapid growing season, after it is once begun, decreases the yield. Excessive moisture, or that applied late in the life of the plant, increases the relative production of vines. The relative number of tubers per hill is increased by early irrigation. while the relative size of the tubers is influenced more by late water. It is very important to have an even supply of moisture during the middle portion of the life of the potato after the tubers begin to form, and before they begin to ripen.

Irrigation experiments with oats show that plats receiving 5 inches of water each week for 6 weeks (total 30 inches) gave the-highest yield, 79.9 bushels. The next highest yield was 79 bushels an acre and was produced with 15 acre-inches of water ( 3 five-inch irrigations) $(6)$.

If water was the only limiting factor here, it is evident that it would be unwise to apply the additional 15 inches to obtain a yield of only one additional bushel, because the same 15 inches if applied to another acre of land might produce the same yield as the first 15 inches or 79 bushels. Land as land is not a limiting factor here, but land of a particular farm so situated as to be readily irrigated and thus to utilize to best advantage the 15 inches of water is a limiting factor. Where the location of land

(1) Meade, Elwood-“Irrigation Institutions" (1910), pp. 116-117. Macmillian Co.. New York.

(2) Harris, F. S., Utah Agr, Exp, Sta. Bul. No. 133, (May, 1914),

(3) Harris, F. S., and Pittman, D. W., Utah Agr. Exp. Sta. Bul. No. 154, (April, 1917), p. 21.

(4) Harris, F. S., Utah Agr. Exp. Sta. Bul. No. 156, (June, 1917), p. 22.

(5) Harris, F. S., Utah Agr. Exp, Sta. Bul. No. 157, (June, 1917), p. 17.

(6) Harris, F. S., and Pittman, D. W., Utah Agr. Exp. Sta. Bul. No.

167, (March, 1919), p. 17. 
limits its use and labor is not a preventing factor, it may be profitable to an individual farmer to apply the additional 15 inches of water in order to obtain the additional yield of one bushel of oats per acre. While this condition may make this practice profitable to an individual farmer, it certainly would be uneconomical from the standpoint of society as a whole, because some farmer in any irrigated area can use 15 inches of water more economically than producing just one bushel of oats.

It is apparent then that three five inch irrigations, (1) at the fiveleaf stage, (2) at the early-boot stage, and (3) in the bloom stage, with an average yield per acre of 79 bushels give the most satisfactory results generally. Where only one irrigation is given the best time is at the five-leaf stage. Where two irrigations are given, (1) the five-leaf, and (2) the boot stages are best.

In the case of alfalfa the first irrigation should occur just before the time of bud formation, and another just before or after each cutting. Four or five inches of water form a fairly large single application. Usually a smaller quantity is sufficient to maintain the crop in good condition (1).

Farm Credit.-That the farmers' ability to get money may affect the type of farming practised in a region has been well demonstrated in the tenant system of single-crop cotton-farming in the Southern States.

Table XXXIII-Farm Mortgages, Hyde Park, Cache County, Utah, 1914

Number of farms reporting ......................................... 52

Number of farms mortgaged........................................... 18

Amount of mortgaged debt (average) ........................\$1,151

Value of land and buildings per farm mortgage (average)

Number of farms on which rate of interest paid

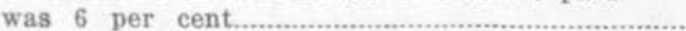

Number of farms on which rate of interest paid was 8 per cent.

12 per cent

er farms on which rate of interest paid was $8 \frac{1}{2}$ per cent.

Number of farms on which rate of interest paid was 9 per cent.

Average rate of interest paid by 18 farmers.

8.03 per cent

Again many farmers of the Intermountain States claim that they would like to go into livestock farming but that they lack the money necessary to get into the business in good shape. The funds a farmer operates with are in tne form of capital goods, cash, or credit. Credit is obtained from banks or other institutions or persons loaning money to farmers, on the basis of the applicants character, capacity, and collateral. The mortgage debt of farmers may therefore be important in determining type of farming. Farmers often obtain funds for construction, development, and operation by mortgaging the farm.

At Hyde Park in 1914, 18 farms out of 52 were mortgaged. The average value of land and buildings per farm mortgaged was $\$ 9,559$ and the average mortgage debt $\$ 1,151$, or 12 per cent of the value of the land and buildings. The rate of interest most common was 8 per cent. Fourteen farmers paid 8 per cent, 1 paid $8 \frac{1}{2}$ per cent, 2 paid 9 per cent,

(1)Widtsoe, J. A., and Stewart, George, "Western Agriculture", (1918), p. 142 . 
Table XX. IV.-Mortgage Debt of Farms by Counties, Utah, 1910 (1)

\begin{tabular}{|c|c|c|c|c|c|c|c|}
\hline \multirow[b]{2}{*}{ Area } & \multicolumn{3}{|c|}{$\begin{array}{l}\text { For all Farms Op- } \\
\text { erated by Owners }\end{array}$} & \multicolumn{4}{|c|}{$\begin{array}{c}\text { For Martgaged Farms Consisting of } \\
\text { Owned Land Only }\end{array}$} \\
\hline & 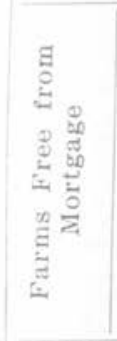 & 总 & 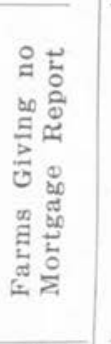 & 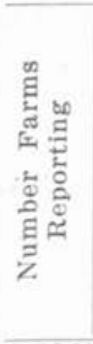 & 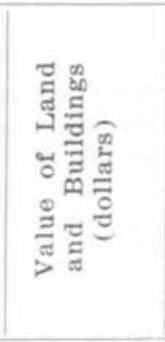 & 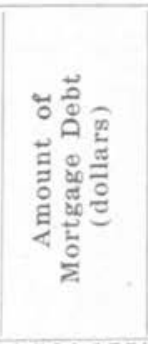 & 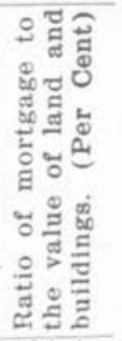 \\
\hline State ............. & 15,131 & 4,492 & 139 & 3,526 & $21,319,580$ & $4,564,175$ & 21.4 \\
\hline Counties & & & & & & & \\
\hline Beaver & 263 & 21 & 1 & 17 & 117,150 & 18,980 & 16.2 \\
\hline Boxelder & 869 & 502 & 11 & 369 & $2,767,325$ & 601,590 & 21.7 \\
\hline Cache ....... & 1,126 & 621 & 9 & 449 & $3,606,494$ & 672,922 & 18.7 \\
\hline Carbon & 132 & 21 & 2 & 19 & 97,700 & 14,520 & 14.9 \\
\hline Davis ... & 937 & 261 & 7 & 225 & $1,702,213$ & 363,731 & 21.4 \\
\hline Emery & 447 & 177 & 1 & 166 & 957,867 & 206,575 & 21.6 \\
\hline Garfield & 318 & 31 & 4 & 30 & 101,885 & 30,065 & 29.5 \\
\hline Grand .. & 129 & 26 & 1 & 21 & 154,295 & 15,198 & 9.9 \\
\hline Iron & 303 & 23 & 7 & 14 & 85,600 & 18,280 & 21.4 \\
\hline Juab & 408 & 68 & 19 & 64 & 327,315 & 93,992 & 28.7 \\
\hline Kane & 152 & 12 & $\ldots .$. & 10 & 37,980 & 9,180 & 24.2 \\
\hline Millard & 585 & 75 & 10 & 56 & 220,330 & 46,560 & 21.1 \\
\hline Morgan & 167 & 46 & & 31 & 189,040 & 24,495 & 13.0 \\
\hline Piute ........ & 132 & 411 & 1 & 33 & 109,250 & 28,667 & 26.2 \\
\hline Rich ................ & 142 & 56 & $\ldots$ & 46 & 382,455 & 122,426 & 32.0 \\
\hline Salt Lake.... & 1,418 & $454 !$ & 4 & 366 & $1,911,295$ & 396,625 & 20.8 \\
\hline San Juan....... & 142 & 9 & ... & 7 & 26,018 & 8,300 & 31.9 \\
\hline Sanpete ....... & 1,307 & 319 & 2 & 256 & $1,177,698$ & 237,972 & 20.2 \\
\hline Sevier ............... & 633 & 315 & 3 & 274 & $1,312,515$ & 266,324 & 20.3 \\
\hline Summit ....... & 355 & 51 & 1 & 42 & 305,313 & 64,585 & 21.2 \\
\hline Tooele .......... & 245 & $44 \mid$ & ..... & 31 & 372,065 & 55,250 & 14.8 \\
\hline Uinta ............... & 457 & 115 & 29 & 105 & 463,975 & 99,819 & 21.5 \\
\hline 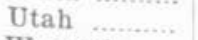 & 1,971 & 648 & 22 & 489 & $2,675,370$ & 650,040 & 24.3 \\
\hline Wasatch ............ & 790 & 98 & 2 & 81 & 491,062 & 118,745 & 24.2 \\
\hline Washington & 553 & 30 & $\ldots$. & 21 & 46,558 & 7,125 & 15.3 \\
\hline Wayne ....... & 208 & 23 & 2 & 18 & 58,200 & 11,195 & 19.2 \\
\hline Weber .............. & 942 & 369 & 1 & 286 & $1,622,612$ & 381,014 & 23.5 \\
\hline
\end{tabular}

and 1 paid only 6 per cent interest on the farm mortgage. The average rate therefore, was 8.03 per cent including commissions, when paid. (See Table XXXII, )

From investigations that have been made here and elsewhere in the State ic seems that these farmers might make more money by extending their operations by increasing the number of acres cropped and the number of productive livestock units handled (2). With the operation of the Federal Land Bank at San Francisco and a Local Farm Loan Association in Cache County these farmers should be able to extend their

(1) 1910 U. S. Census.

(2) Brossard, E. B.. Utah Agr. College Cir. No. 23, and also Utah Agr. Exp. Sta. Bul. No. 160 . 
operations considerably by using funds obtained by credit based on the farm mortgage.

Under the Federal Farm Loan Act farmers are able to borrow as much as 50 per cent of the value of the land for agricultural purposes and 20 per cent of the value of the permanent insured improvements. At present the interest rate is $51 / 2$ per cent. The loan may be obtained for a period of 40 years if desired with the privilege of paying it or any part of it any time after 5 years. Regular payments on the amortization plan are required each year.

In Cache County in 1910.(1), 621 farms were mortgaged, 449 of which consisted of owned land only. The total value of the land and buildings mortgaged was $\$ 3,606,494$, and the mortgage debt $\$ 672,922$, or 18.7 per cent of the value of land and buildings. (See Table XXXIV).

Table XXXV.--Farm Mortgages, Utah and the United States, 1910 (1)

\begin{tabular}{|c|c|c|}
\hline & Utah & U. S. \\
\hline 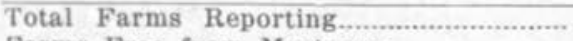 & 19,762 & $3,948,722$ \\
\hline Farms Free from Mortgage.......................... & 15,131 & $2,588,596$ \\
\hline 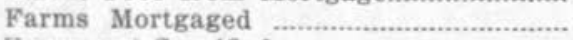 & 4,492 & $1,312,034$ \\
\hline 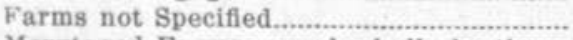 & 139 & 48,092 \\
\hline $\begin{array}{l}\text { Morgtaged Farms owned wholly by the } \\
\text { Operator }\end{array}$ & 3,526 & $1,006,511$ \\
\hline Value of Land and Buildings on Mort- & $0,0<0$ & $1,000,0 \times 2$ \\
\hline $\begin{array}{l}\text { gaged Farms } \\
\text { Amount of Mortgaged Debt }\end{array}$ & $\$ 21,319,580$ & $\$ 6,330,236,951$ \\
\hline Mortgaged Farms owned wholly by the & 4,175 & $1,726,172,851$ \\
\hline $\begin{array}{l}\text { Land and Buildings (per cent).......... } \\
\text { Average Value of Land and Buildings }\end{array}$ & 21.4 & 27.3 \\
\hline per Farm & 6,046 & 6,289 \\
\hline Average Mortgage Debt per Farm......... & 1,294 & 1,715 \\
\hline 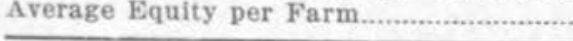 & 4,752 & 4,574 \\
\hline
\end{tabular}

In Utah in $1910(1)$, of 19,762 farms reporting, 15,131 were free from mortgage, 4,492 were mortgaged, and 139 did not specify. There were 3,526 mortgaged farms wholly owned by the operators. The value of land and buildings on these farms was $\$ 21,319,580$ and the mortgage debt was $\$ 4,564,175$, or 21.4 per cent of the value of land and buildings. This ratio for the United States as a whole was 27.3 per cent.

The average value of land and buildings per farm in Utah, 1910, was $\$ 6,046$ and the average mortgage debt per farm was $\$ 1,294$ thus leaving an average equity of $\$ 4,752$ per farm. For the United States as a whole the average value of land and buildings per farm was $\$ 6,289$, the average mortgage debt $\$ 1,715$, and the average equity $\$ 4,574$ per farm. (See Table XXXV).

A fairly accurate estimate (2) of the farm mortgage debt of all Utah farmers in 1914 places it at $\$ 6,818,000$, of which $\$ 6,000,000$ or 88 per cent was held by banks, $\$ 862,000$, or 12.6 per cent, held by life insuragents or correspond $\$ 340,000$ negotiated by banks and bank officials as exactly because they for other investors. These figures do not check has been made to force them. the farm mortgage business. It is also estimated that 67 per cent of cent of the business pays an averah, pays no commission and 33 per

mission of .4 per cent. Of the

(1) 1910 U. S. Census, Vol. 5, Tables 9, 11, and 12.

ization, Bul. No. 384 , (July, D. D. A., Office of Markets and Rural Organ- 
total mortgasu business 18.3 per cent pays a commission in advance and 14.7 per cest fays it on the installment plan. The average mortgage rate of intercs paid was 8.6 per cent, which makes 9 per cent with the commission. Hin estimated average interest rate for farm loans on personal serirliy in Utah, 1914 (1), was 8.8 per cent and the estimated average othit cosis of the loans, 1.6 per cent, making the average estimated totni cost, including discounts, bonuses, commissions and any other extri tharges, 10.4 per cent. Only in unusual cases can farmers pay this higit tule and make a profit in farming.

Farm iroilto. Farm profits are largely determined by the type of iarming practised. The type of farming most profitable depends upon the circumsinding of the individual farmer and farm. Two of the first questions that arise in one's mind are: (1) Is farming profitable? and (2) How luofltible is it?

Table $X \times X 11$ shows the average labor income of 52 Hyde Park farmers in 1914. The value of the farm house is included as a part of the capital investment. the increase in the value of land is omitted, and the interest rate usid is 8 per cent.

Table XXXYT.-Average Labor Income, 52 Farms, Hyde Park, 1914

\begin{tabular}{|c|c|}
\hline Capital Investment & \\
\hline $\begin{array}{l}\text { Receipts } \\
\text { Expenses }\end{array}$ & \\
\hline
\end{tabular}

Farm Income (Receipts less expenses) ...............

Interest on Capital Investment (at 8 per cent)....

Labor Income

At 5 per cent $(2)$, interest is $\$ 682$ and labor income, $\$ 946$; at $5 \frac{1}{2}$ ber cent $(3)$, interest is $\$ 750$ and labor income $\$ 878$; at 8 per cent $(4)$, interest is $\$ 1,091$ and labor income $\$ 537$; at 8.6 per cent $(5)$, interest is $\$ 1,173$ and labor income $\$ 455$; and at 9 per cent $(6)$, interest is $\$ 1,228$ and labor income $\$ 400$.

Table XXXVII shows the farmer's pay for management and risk or responsibility taken, 52 farms, Hyde Park, Cache County, Utah, 1914.

Table XXXVIII shows the labor income of the 10 better-paying farms of Hyde Park in 1914. At 5 per cent, interest is $\$ 991$ and labor income, $\$ 1,997$; at $51 / 2$ per cent, interest is $\$ 1,090$ and labor income, $\$ 1,899$; at 8 per cent, interest is $\$ 1,585$ and labor income, $\$ 1,403$; at 8.6 per cent, interest is $\$ 1,704$ and labor income, $\$ 1,285$; and at 9 per cent, interest is $\$ 1,783$ and labor income, $\$ 1,206$.

(1) Thompson, C. W., U. S. D. A., Office of Markets and Rural Organization, Bul. No. 409, (August, 1916), D. 6.

(2) The investigators of the Office of Farm Management, U. S. D. A. use 5 per cent interest for all districts in the United States in calculating labor income. (a) Thompson, E. H., and others, U. S. D. A., B. P. I., Bul. No. 41, (Jan., 1914); (b) Thompson, E. H., and others, U. S. D. A., B. P. I., Bul. No. 117, (July, 1914); (c) Spillman, W. J., and others, U. S. D. A., Farm Mgt. Bul. No. 341, (Jan., 1916); and (d) Connor, L. G., U. S. D, A., Farm Mgt. Bul. No. 582, (Jan., 1918), Note, p. 2.

(3) The Federal Farm Loan Act of July 17, 1916, provides that interest rate on farm nortgage loans shall not exceed 6 per cent, nor be more than 1 per cen: greater than the rate on the last issue of farm loan bonds. The present rate on farm mortgages under this act is $51 / 2$ per cent.

(4) The most common rate of interest at Hyde Park and in the State.

$\left.{ }^{5}\right)$ The estimated average mortgage rate without commission for Utah.

(6) The estimated average mortgage rate including commissions, Utah. 
Table XXXVII.-The Farmer's Pay for Management and Risk or Responsibility Taken, Hyde Park, Cache County, Utah, 1914

Number of Farms.

52

Capital Investment (1)

Total Income

Farm sales and increase in inventory other than land..

Value of farm products, food and fuel, used in home (2)

Increase in value of land $(105 \mathrm{~A}$. at $\$ 2.50$ per A. $)(3)$

$\$ 12,307$

2,510

411

262

Total Subtractions

Unpaid family labor

204

Help hired by month or year.....................................

Help hired by day or piece.

56

116

Cash expense for board of hired help................................. 11

Other cash farm expenses............................................. 495

Opportunity value of farmer's labor(4) ...................... 600

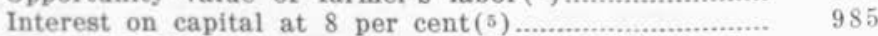

Farmer's Pay for Management and Risk or Responsibility taken (Total income minus total subtractions).

Table XXXIX shows the farm capital, receipts, expenses, farm income, interest on investment, and labor income of farms of the Hyde Park area, Cache County, Utah, 1915. At 5 per cent, interest on the average capital invested in the 48 farms is $\$ 599$ and labor income $\$ 589$; at $5 \frac{1}{2}$ per cent, interest is $\$ 569$ and labor income $\$ 529$; at 8 per cent, interest is $\$ 959$ and labor income $\$ 229$; at 8.6 per cent, interest is $\$ 1,031$ and labor income $\$ 157$; and at 9 per cent, interest is $\$ 1,076$ and labor income $\$ 112$. The average of the 10 better-paying farms has a labor income of $\$ 1,446$ with interest at 5 per cent, $\$ 1,374$ with interest at $5 \frac{1}{2}$ per cent, $\$ 1,015$ with interest at 8 per cent, $\$ 920$ when interest is 8.6 per cent, and $\$ 872$ with interest at 9 per cent. The average of the 10 poorer-paying farms had a labor income of minus $\$ 93$ with interest figured at 5 per cent.

Table XL shows the labor income of farmers of the Hyde Park area, Cache County, Utah, 1916. The labor incomes of the farmers of this

(1) Average capital investment, 52 farms, $\$ 13,642 ;$ minus $\$ 1,335$, average yalue of dwelling, 50 farms.

(z) Funk, W. C., U. S. D. A., Farmers' Bul. No. 635, (Dec., 1914), p. 5, gives $\$ 64.19$ as the average value per person of food and fuel produced on the farm and consumed in the farm home on 483 farms in 10 representative districts of the United States. At Hyde Park the farmers use about the average amount of fuel and food items mentioned in this bulletin and in addition get their year's supply of wheat for flour which is taken as grist to the mills. The average consumption per person of wheat for flour in the United States in 1914 was about 5 bushels. The average price of wheat in Utah Dec, 1, 1914, was $\$ 0.86$. The value of wheat used for flour per person was, therefore, $5 x \$ 0.86$, or $\$ 4.30$. $\$ 4.30$ plus $\$ 64.19$ equals $\$ 68.49$ per person in the farm family. There were, on the average, 6 persons per family on the farms at Hyde Park, 1914, and $6 x \$ 68.49$ equals $\$ 410.84$ per family, or in whole numbers, $\$ 411$.

(s) 1910 U. S. Census shows that in the ten years ending April 15. 1910 , land in Cache County, increased in value $\$ 24.93$ per acre, from $\$ 12.92$ in 1900 to $\$ 37.85$ in 1910 . This amounts to $\$ 2.50$ an acre each year. It is assumed that land at Hyde Park increased at this same rate. $\$ 1,000$

(4) Estimated by the farmers. The estimates varied from $\$ 200$ to

(s) The most common rate of interest paid at Hyde Park and else-
ere in Utah. where in Utah. 
Table XXXVIII.-Business Statement of the Average of 10 BetterPaying Farms of the Hyde Park Area, Cache County, Utah, 1914. Showing Type of Farming and Labor Income

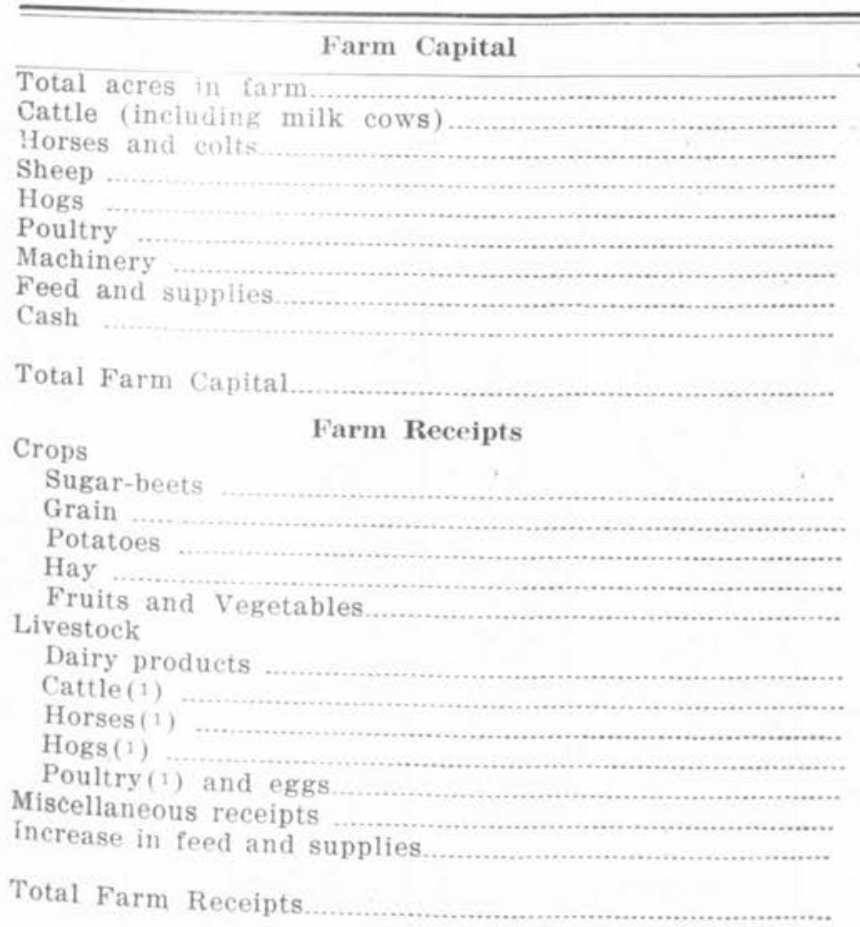

\begin{tabular}{rr} 
No. & Value \\
\hline 226 & $\$ 16,152$ \\
27 & 1,225 \\
10 & 1,204 \\
1 & 4 \\
6 & 72 \\
77 & 35 \\
& 542 \\
& 542 \\
& 51 \\
\hline$\$ 19,816$
\end{tabular}

$\$ 19,816$

$\$ 1,070$

Hired labor (2)

Farm Expenses

Value of family labor (3)

Taxes

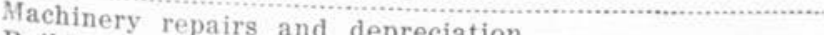

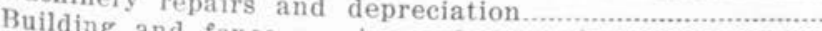

Feed

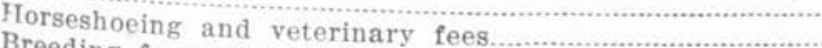

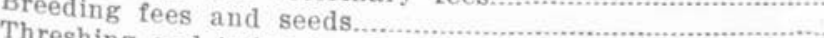

Threshing and twine (excludes toll)

Machine work hired...

Water tax

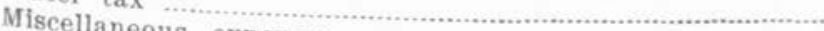

Total Farm Expenses

Farm Income

Interest one (receipts minus expenses)

(1) The receipts from stock are found by subtracting the sum of the purchases and what is on hand at the beginning of the year from the
sum of sum of the sales and that on hand at the close of the year.

(3) Includes cash expense of boarding hired labor.

(3) Except that of the operator of the farm. 
Table XXXIX.-Business Statement of Farms of Hyde Park Area, Cache County, Utah, 1915, Showing Type of Farming

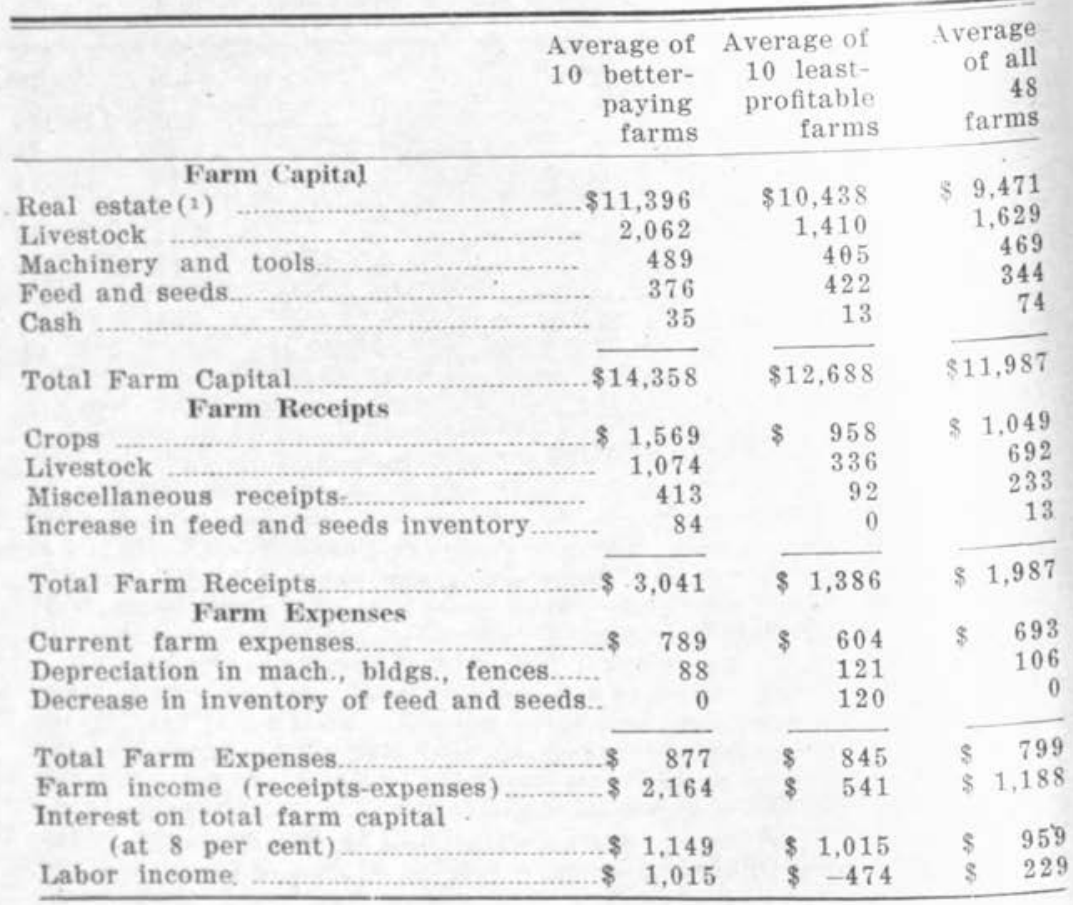

area are better than the average of the State and perhaps some better than the average of the country as a whole. The business is about the same each year and tho there are always a few who make very little If anything, the profits of the majority are normal.

Table XLI shows the average, total, and yearly labor income of each of 32 Hyde Park farmers who cooperated for eảch of the three years, 1914 . 1915 , and 1916. They are separated into three groups, the 10 betterpaying farms, the 12 medium-profitable farms, and the 10 least-profitable farms. It should be noted that in general the farms which have a highaverage labor income have also a large one for each of the three years and those having a low-average have also a small labor income each year. There are, however, some farmers whose labor income has varied greatly. In these cases special conditions and circumstances have been the cause. The following facts from two farm statements illustrate this point.

Farm 2, L-6, was less successful in 1915 because of failure of dryfarm wheat. Farm 4, L-2, was not so successful in 1915 on account of having only $\$ 42$ worth of potatoes to sell instead of the $\$ 250$ worth as in 1914, as but one instead of two and a half acres was planted. His livestock was not nearly so profitable in 1915 because of misfortune with calves, colts, and pigs. And his expenses were $\$ 500$ greater. The increase in expenses was due to a grown son's help on the farm for a longer period, thus lightening the labor of the operator, but increasing

(I) Real estate includes all land, buildings, fences, drains, etc., at their market value at the beglnning of the farm year, or January $1,1915$. 
Tabi- Xl.-Business Statement of Farms of Hyde Park Area, County, Utah, 1916, Showing Type of Farming

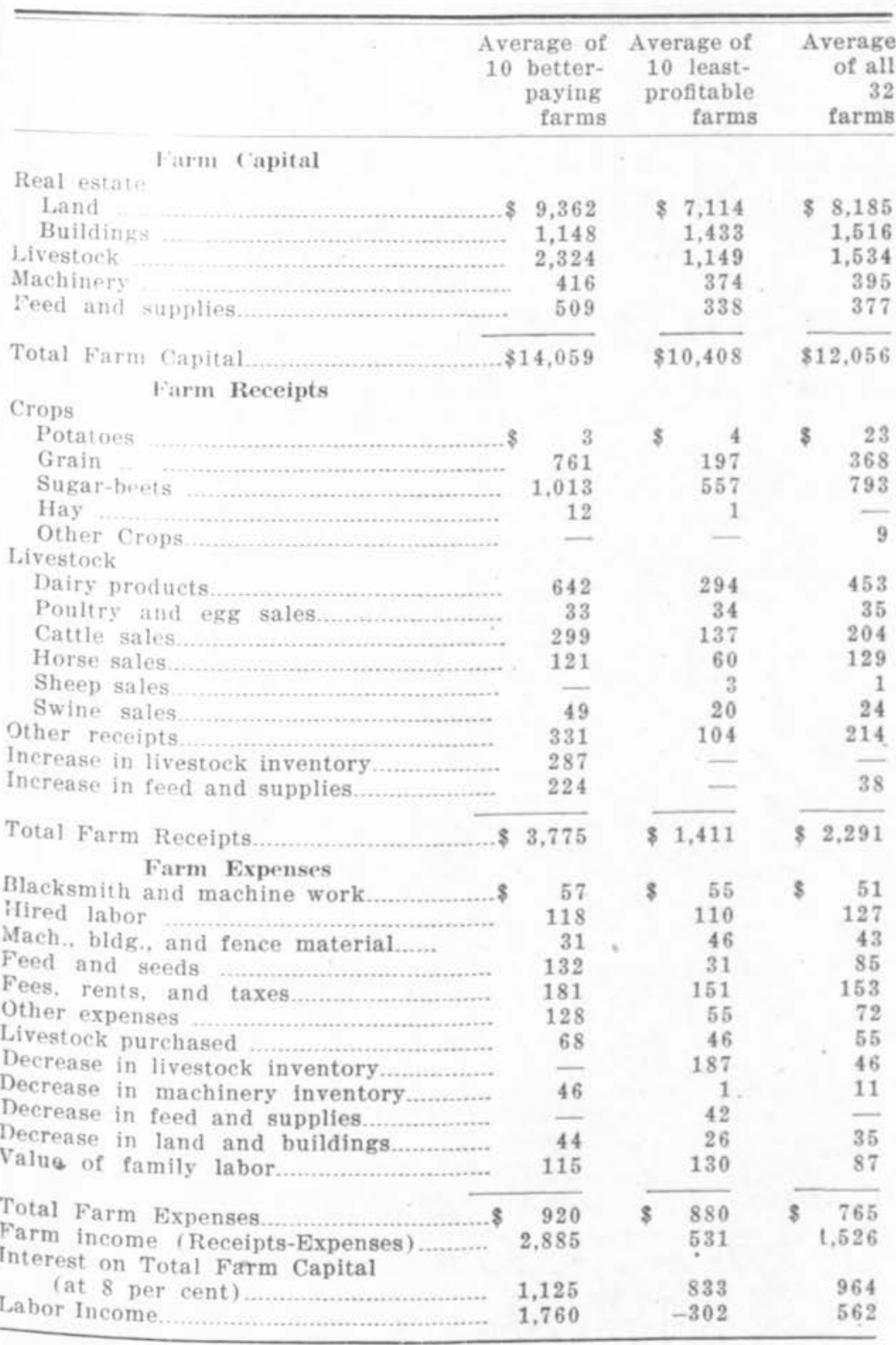

the expense for unpaid family labor, and to the fact that $\$ 272$ worth of hay was purchased because of the unusually cold winter making more feed necessary, the drought in July and August "burning up" the ranges. 
Table XLI.-Labor Incomes(1) of 32 Farmers, Hyde Park, Cache County, Utah, 1914, 1915, and 1916

\begin{tabular}{|c|c|c|c|c|c|c|}
\hline & Farm & & & oor Income & & \\
\hline Order & Number & Average & Total & 1914 & 1915 & 1916 \\
\hline 1. & B-3 & $\$ 3,419$ & $\$ 10,257$ & $\$ 1,949$ & $\$ 2,435$ & $\$ 5,873$ \\
\hline 2. & L-6 & 2,831 & 8,494 & 4,277 & 345 & 3,872 \\
\hline 3 & P-2 & 1,857 & 5,570 & 1,301 & 1,629 & 2,640 \\
\hline 4. & L-2 & 1,559 & 4,678 & 2,226 & 950 & 1,502 \\
\hline 5. & W-2 & 1,487 & 4,462 & 1,306 & 1,703 & 1,453 \\
\hline 6. & $\mathrm{H}-2$ & 1,276 & 3,827 & 1,840 & 1,172 & 815 \\
\hline 7. & L-1 & 1,267 & 3,801 & 1,395 & 1,185 & 1,221 \\
\hline 8. & C-1 & 1,169 & 3,506 & 1,004 & 1,123 & 1,379 \\
\hline 9. & L-3 & 1,084 & 3,251 & 1,644 & 1,043 & 564 \\
\hline 10. & S-3 & 1,083 & 3,248 & 1,287 & 1,167 & 794 \\
\hline Total & & 17,032 & 51,094 & 18,229 & 12,752 & 20,113 \\
\hline Average & & 1,703 & 5,109 & 1,823 & 1,275 & 2,011 \\
\hline 11. & A-1 & 1,027 & 3,080 & 1,772 & 154 & 1,154 \\
\hline 12. & W-1. & 988 & 2,963 & 1,537 & 1,126 & 301 \\
\hline 13. & $\mathrm{~N}-1$ & 942 & 2,826 . & 947 & 1,022 & 857 \\
\hline 14. & $\mathrm{~J}-1$ & 928 & 2,783 & 928 & 251 & 1,504 \\
\hline 15. & S-4 & 841 & 2,524 & 850 & 659 & 1,015 \\
\hline 16. & R-1 & 787 & 2,360 & 1,425 & 643 & 292 \\
\hline 17. & S-5 & 773 & 2,319 & 889 & 468 & 962 \\
\hline 18. & K-2 & 732 & 2,196 & - 1,065 & 399 & 732 \\
\hline 19. & K-1 & 681 & 2,043 & 1,166 & 883 & -6 \\
\hline 20. & D-1 & 622 & 1,865 & 768 & 698 & 399 \\
\hline 21. & G-1 & 613 & 1,839 & 654 & 437 & 748 \\
\hline 22. & B-2 & 557 & 1,672 & 1,039 & 296 & 337 \\
\hline Total & & 9,491 & 28,470 & 13,040 & 7,036 & 8,395 \\
\hline Average & & 791 & 2,372 & 1,087 & 586 & 700 \\
\hline 23. & W-5 & 514 & 1,543 & 775 & 738 & 30 \\
\hline 24 & R-2 & 492 & 1,476 & 708 & 299 & 469 \\
\hline 25. & H-3 & 419 & 1,257 & 843 & 210 & 204 \\
\hline 26. & $\mathrm{H}-1$ & 418 & 1,253 & 484 & 57 & 712 \\
\hline 27. & C-3 & - 207 & 620 & 483 & 104 & 33 \\
\hline 28. & L-4 & 153 & 459 & -58 & 327 & 190 \\
\hline 29. & P-1 & 67 & 202 & 63 & -50 & 189 \\
\hline 30. & C-4 & -40 & -121 & 86 & -153 & -54 \\
\hline 31. & S-2 & -105 & -315 & 156 & -130 & -341 \\
\hline 32. & F-1 & -222 & -666 & 2 & -237 & -431 \\
\hline Total & & 1,903 & 5,708 & 3,542 & 1,165 & 1,001 \\
\hline Average & & 190 & 571 & 354 & 116 & 100 \\
\hline Grand $T$ & Total & 28,426 & 85,272 & 34,811 & 20,953 & 29,509 \\
\hline Grand & Average & 888 & 2,665 & 1,088 . & 655 & 922 \\
\hline
\end{tabular}

and to the fact that he raised but 46 tons of hay instead of 54 as in 1914 , due to fewer acres planted.

The variations in labor income from year to year on an individual

(1) 5 per cent interest on investment was subtracted in calculating labor income. 
farm result from the various causes which affect farm profits on different farms, because each year, in a measure, presents an entirely new set or combination of conditions which the farmer has to meet and over a great many of these factors he has no control whatever.

The landlords, who rented out their land to farmers that wanted it to work with their own farms, received on the average between 6 and 7 per cent net return on the investment. The owner usually pays the taxes on rented land, which average about 0.8 per cent at Hyde Park for both land and water, and these with all other expenses have been deducted. The percentage which the net rent forms of the total investment varied from 3 to 18 .

With land values increasing as they have in the past, at the rate of about $\$ 2.50$ per acre annually, and an annual income of 6 to 7 per cent on the investment, owning Hyde Park farm land has been profitable. Men would buy farm land in preference to loaning their money on farm mortgages if interest rates were considerably higher than 8 per cent because of the rise in land value and the rent they are able to get from its use in farming.

Table XLII shows the labor income(1) of Utah farmers for the year 1909 as calculated from the 1910 U. S. Census. Using 0.5 per cent as the tax rate and 5 per cent interest the labor income was $\$ 322$. Using 0.6 per cent as the tax rate and 5 per cent interest the labor income was $\$ 313$. Using $0.8(2)$ per cent tax rate and 8 per cent interest labor income was $\$ 88$. With interest at 8.6 per cent, labor income was $\$ 47$, and with interest at 9 per cent, labor income was $\$ 19$.

In calculating this labor income no credit or debit was made for increase or decrease in the value of farm land. This increase or decrease is an important factor in the farmer's income. The $1910 \mathrm{U}$. S. Census shows that in the decade 1900 to 1910 farm land in Utah increased in value at the rate of 11.625 per cent compounded annually on the 1900 value(3). In Minnesota farm land increased at the rate of 5.6 per cent compounded annually on the 1900 value(4). In the United States as a whole, it increased at the rate of 5.621 per cent compounded annually. The average increase in the value of an acre of land each year for the lecade 1900 to 1910 was in Utah, $\$ 1.95$; in Minnesota, $\$ 1.55$; and in the United States as a whole, $\$ 1.68$. The average labor income of farmers of the United States as a whole for the year 1909 was $\$ 318(5)$. Taxes were figured at 0.6 per cent and interest at 5 per cent. Using 0.5 per cent as tax rate and 5 per cent interest the average labor income of Minnesota farmers for the same year was $\$ 330(0)$.

(1) Method of calculation is that used by W. J. Spillman in U. S. D. A. B. P. I., Cir. No. 132, (July, 1913); and by F. W. Peck in Minn. Farm Management Service Notes, Cir. No. 2, (March, 1914). Includes unpaid family labor and all the farm furnishes towards the family living except milk. Does not include income from outside sources; and the amount paid for livestock bought must be deducted.

(2) Third An. Rpt., Utah Bur. Immig. Lab. and Stat., (1917), p. 350, shows that the State and State School tax levy was 8 mills in 1909 . The average taxes paíd by the 10 better-paying farms in each of 6 areas in 1914 was 8.2 mills on each dollar invested in the farm business.

(3) Brossard, E. B., Utah Exp. Sta. Bul. No. 160, (Sept., 1917).

(4) Boss, A., and Benton, A. H., and Cavert, W. M., Minn. Exp. Sta. Bul. No. 170 , (Oct., 1917),

(5) Spillman, W. J., U. S. D. A., B. P. I., Cir. No. 132, (July, 1913). 1914). 
Table XLII.-Labor Incóme of Utah Farmers, 1909 (1910 Census Report)

\begin{tabular}{|c|c|c|}
\hline Item & Total & Per farm \\
\hline Number of farms............... & 21,676 & $156.7(1)$ \\
\hline Improved land (acres). & $1,368,211$ & 63.1 \\
\hline Total Farm investment... & $150,795,201$ & $\$ 6,957$ \\
\hline 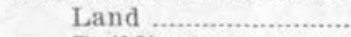 & $99,482,164$ & 4,590 \\
\hline Buildings ...... & $18,063,168$ & 833 \\
\hline Maehinery . & $4,468,178$ & 206 \\
\hline Livestock ... & $28,781,691$ & 1,328 \\
\hline
\end{tabular}

Dairy products (excluding milk Receipts cream used at home on the farm) ...... \$

Poultry and eggs produced........................

Honey and wax produced

$2,067,534$

$1,259,267$

79,763

Wool and mohair produced......................

Animals sold

$1,891,221$

$5,899,382$

756,854

Total value of all crops ........\$18,484,615

Corn …....... \$ 134,396

Oats ….......... 1,671,065

Barley …...... 472,816

Hay ….......... 7,429,901

$54-35$

Total value of feed crops........\$ 9,708,178

Receipts from sale of feed

crops.

Net value of crops fed..........\$ $8,371,979$

Net value of crops

$10,112,636$

Total gross farm income

\section{Expenses}

Labor

$\$ 22,066,658$

Rent and board furnished.

Fertilizer

\& $2,863,709$

306,208

20,037

Feed

727,409

Maintenance of buildings (at $5 \frac{1}{2}$ per cent of value)

Maintenance of machinery and implements ( 20 per cent of value)

Taxes ( 0.8 per cent)

993,474 
Summary.-Special mention should be made of some of the principal points concerning the type of farming at Hyde Park. The combinations of enterprises are the result of the "survival of the fittest" in the competition of enterprises for a place in the farm business. The number of livestock in the area is increasing but its increase depends largely upon the development of the farm pastures and the improvement of the ranges and of necessity is gradual. The climate, soil, and topography limit the use of much land in this area to the grazing of livestock. The farm business of the area is diversified and fairly well balanced when all of the farm, family, and labor conditions are taken into consideration. The size of farm business is not great, but it is based upon the farm family as the unit of organization, and seems in most cases to be fairly well adapted to the conditions. The farm machinery and buildings are similar to those found on farms elsewhere in the country. One distinctive feature, which has a decided effect upon the type of farming, is the location of the farm buildings and the farm family in town instead of on the farms.

The administration of the National Forests by the Federal Government limits the use of the range to land-owning farmers and establishes priority of rights on the ranges and protection for these rights and thus influences the type of farming practised on some farms. The National Forests and range-stock farming are closely correlated.

The population and the character of the individual persons have affected the type of farming at Hyde Park by limiting markets for some farm products, establishing markets for others, and by determining the abilities and training of farmers to produce successfully the crops and livestock wanted. The farmer and his family do most of the farm work. The families are large and the children contribute considerably to the family income by milking cows and working in the sugar-beets. The sugar-beet enterprise was made possible by the establishment of Sugar Factories.

No tenant farms are included in this investigation. Some owners rent additional land. The percentage of tenancy is low in Cache County and Utah because (i) it is a relatively new country and until recently it was easy for one to become an owner and thus take advantage of the rise in the value of land; (2) the natural sentiment of the people is ngainst tenancy and in favor of owning their own homes and businesses, for religious and social as well as economic reasons; and (3) the type of farming practised and range and water conditions all tend to make it desirable to own all or a large part of the farm land one operates. Even tho land values are based upon the productivity of the land, the farmer on a given farm must select such farm enterprises as will be profitable on his land, and thus on the individual farm, land values determine to some extent the type of farming.

The irrigation water avallable, the ownership and operation of irrigation canals, the duty of water, the amount of water required by crops, and the proper times of applications on the various crops are all factors influencing the type of farming at Hyde Park.

The farm credit institutions and the available money for farm operations undoubtedly are important factors influencing type of farming in individual cases, but with the operation of the Federal Land Bank some of the credit needs of these farmers may be met.

All the foregoing factors and many others influence the type of farming and thus farm profits. At Hyde Park, profits are not phenominally high nor discouragingly low. On the average they allow a good living for the farm family and in addition farmers are "getting ahead." 


\section{BEAVER, BEAVER COUNTY, UTAH}

The seven remaining areas are treated briefly, and each compared with Hyde Park. Some outstanding points of difference and similarity are noted.

The city of Beaver is situated about 300 miles west of south of Hyde Park. It is in the eastern part of the southeast quarter of Beaver County, in township 29 south, and range 7 west of Salt Lake Meridian.

The elevation at Beaver is 6000 feet or about 1500 feet higher than Hyde Park.

Table XLIII.-Tenure and Use of Farm Land per Farm, 50 Farms, Beaver, Beaver County, Utah, 1914

\begin{tabular}{|c|c|c|c|}
\hline Item & $\begin{array}{c}\text { Farms } \\
\text { Reporting }\end{array}$ & $\begin{array}{c}\text { Average Acres (1) } \\
50 \\
\text { Farms }\end{array}$ & $\begin{array}{c}\text { Average Acres (1) } \\
\text { Farms } \\
\text { Reporting }\end{array}$ \\
\hline Farm Area................. & 50 & 179 & 185 \\
\hline Owned by Operator & 48 & 174 & 123 \\
\hline Cash-rented Land.. & 4 & 3 & 34 \\
\hline Share-rented Land.. & 5 & 3 & 25 \\
\hline 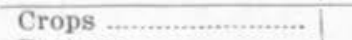 & 50 & 67 & 67 \\
\hline 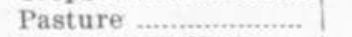 & 44 & 27. & 31 \\
\hline Summer Fallow..... & 2 & 0 & 5 \\
\hline Farmstead and Waste & 48 & 12 & 12 \\
\hline Uncultivated ............ | & 16 & 71 & 222 \\
\hline Irrigated Land & & & \\
\hline 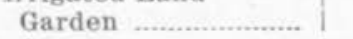 & 12 & 0 & 1 \\
\hline Carrots & 2 & 0 & 0 \\
\hline Corn for Grain........ & 11 & 0 & 2 \\
\hline Corn for Silage...... & 2 & 0 & 2 \\
\hline Potatoes ...................... & 38 & 1 & 1 \\
\hline Spring Wheat........... & 36 & 5 & 7 \\
\hline Winter Wheat............... & 2 & 0 & 7 \\
\hline 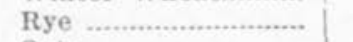 & 2 & 0 & 7 \\
\hline Oats & 33 & 7 & 10 \\
\hline Barley ........................ & 20 & 2 & 4 \\
\hline Oat Hay ................... & 9 & 2 & 10 \\
\hline Hay ........................ & 18 & 5 & 14 \\
\hline 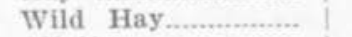 & 18 & 11 & 30 \\
\hline Alfalfa ............................. & 49 & 33 & 33 \\
\hline Oats and Peas......... & 4 & 1 & 8 \\
\hline Peas …….................... & 2 & 0 & 1 \\
\hline Cabbage ..................... & 2 & 1 & 14 \\
\hline Beets & 2 & 0 & 1 \\
\hline Apples, not Bearing & 2 & 0 . & 1 \\
\hline Apples, Bearing......... & 1 & 0 & 0 \\
\hline Beans and Alfalfa. & 1 & 1 & 29 \\
\hline Plums & 1 & 0 & 0 \\
\hline Berries ..................... & 1 & 0 & 0 \\
\hline
\end{tabular}

Table XLIII shows the tenure and use of farm land at Beaver in 1914. On the average there were 179 acres to the farm, of which about 174 acres were operated by the owners, 3 acres cash rented, and 3 acres share rented by the operator. About 69 acres were in crops, 27 acres were in pasture, 71 acres were uncultivated, and 12 acres were in the farmstead, roads, lanes, ditches, and other waste land. There was no land dry-farmed in this area in 1914.

(1) Areas are given to the nearest acre. 
Based on acreage, alfalfa was the main crop occupying 33 acres. Wild hay occupied 11 acres and other hay 5 acres, and oat hay 2 acres, or a total including alfalfa of 51 acres in hay, or 75 per cent of the total area in crops. Other crops and acreages grown are: oats, 7 ; spring wheat, 5 ; barley, 2 ; potatoes, 1 ; oats and peas, 1 ; cabbage, 1 ; and fruit and other vegetables, 1 . The significant fact about the crops grown is the large acreage in hay. This hay is grown largely for feed for livestock. Dates of farm crop operations are shown in Table XXXVII in Appendix.

Table III in Appendix shows the capital, receipts, expenses, and labor income of the average of 10 better-paying farms. It shows livestock and stock products to be the main sources of income.

However, some hay, grain, a few potatoes, and a little fruit are sold. The crops sold are consumed locally. Some feed, $\$ 47$ worth, was bought locally, and cash rent and Forest Reserve fees amounted to $\$ 18$. Expenses for hired labor were $\$ 600$, and for unpaid family labor $\$ 96$, or a totitl labor expens? of about $\$ 696$ besides that of the operator of the farm.

The two main sources of income on the average farm as well as on the: average of the ten better-paying farms were cattle and sheep as shown in Table $\mathrm{IV}$ in Appendix. The better-paying farms had a larger business anc their livestock was more productive in proportion to feed fed. Man and horse labor were both more efficient on the better-paying farms than on the average farm.

Tables V, VI, and VII in Appendix show the same facts about the type of farming in this area for the years 1915 and 1916 as was shown extant in 1914. However, the labor income of the farmers was greater, on the average, in 1915 than 1914 and greater in 1916 than 1915 . The average labor income on all 44 farms in 1916 was $\$ 711$. The average of the ten least-profitable farms was minus $\$ 613$, and of the ten mostprofitable farms it was $\$ 2537$.

The farm business at Beaver is well diversified. Cattle, sheep, dair;ing, and feed and a surplus of hay, grain, and potatoes as cash crops make a fairly well balanced business. During the winter months, however, many farmers sons spend too much of their time in town playing pooi, etc., instead of at productive farm labor.

The Beaver farms are larger than the Hyde Park farms but the type of farming is more extensive at Beaver. At Hyde Park there are more acres of intensive crops and more dairy cows and fewer acres of hay and fewer range cattle and sheep.

The average value of farm machinery on each farm is greater at Beaver than at Hyde Park. This is another reason for the fewer men and horses in proportion to acres of crops and number of animal units at Beaver than at Hyde Park.

The value of farm buildings is slightly less at Beaver than at Hyde Park due in part, to warmer climate, more recent settlement, and fewer dairy cows.

The average crop-growing season is 25 days shorter than at Hyde Park. The mean annual temperature is 48.5 degrees $F$. or about 1 degree higher than for Hyde Park. The temperature is warmer in summer and not so cold in winter at Beaver. The annual precipitation is only about 13 inches at Beaver. All the crops are irrigated.

The Beaver farm-land begins at the base of the mountains on the east and south and extends out west and north to the bottom of the valley, where seepage and excess irrigation water has resulted in some of the low-lying land becoming too wet to be utilized in its present condition, for other purposes than permanent meadow or pasture. The iand is practically level but slopes gently towards the bottom valleyland from the bench land. 
This land is in the Great Interior Soil Province(1). (See Fig. 15). The soil has the characteristics of arid soils in general (2).

The Fillmore National Forest is easily accessible to the cattle and sheep of the Beaver farmers(3). The Millard Desert affords winter sheep-range near at hand. However, these ranges are now stocked to their capacity, and must be handled more carefully or they will not even maintain their present earrying capacity.

The population of the city of Beaver was 1899 in $1910(4)$. A large proportion of those persons in the population who were born in the United States came from other parts of Utah, and other western and middle western states, to Beaver. The foreign-born population is largely from northern Europe and Great Britain. Practically the same situation prevails here as was found at Hyde Park.

The average number in the farm families on the farms at Beaver in 1914 was 5.4. Of these 2 were less than 16 years old and 3.4 over 16 years of age.

The average number of men employed per farm was 1.4. That is the operator's full time and the equivalent of 0.4 of a year of other man labor performed either by other members of the farm family or by hired help. This is two and one-half months less man labor than was utilized at Hyde Park.

Table XLIV.-Size of Family and Number of Cows Kept, Beaver, Beaver County, Utah, 1914

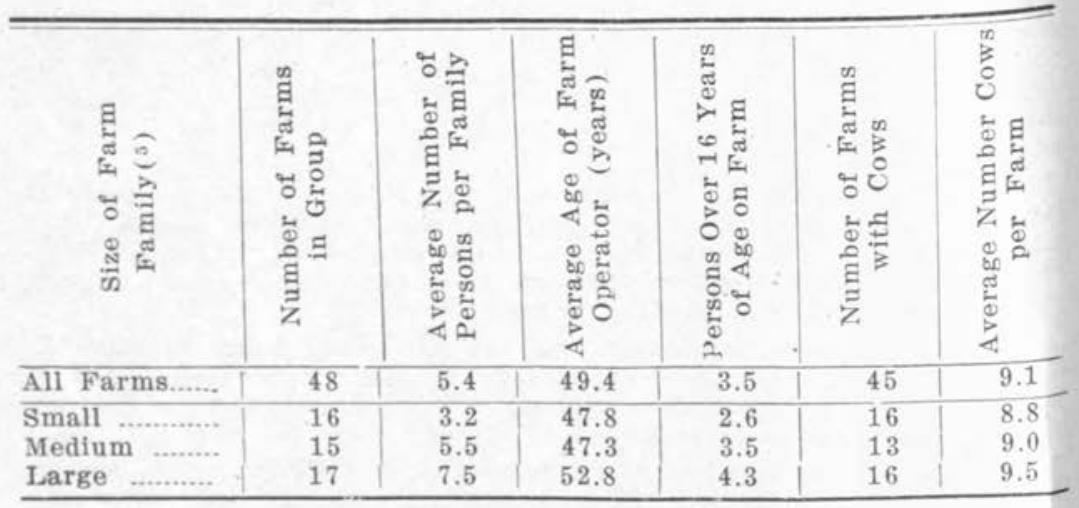

The cows shown in Table XLIV are in most cases just common grade shorthorn cows. Many of them were range cows that were milked only a few months. It was impossible from the records taken to get accurately the average number of cows milked on each farm for the year or 12 month basis. Records of the two largest range cattle operators, cne reporting 96 cows and one 80 cows were omitted from the table because it was so evident that their cows were not all milked even for $\mathbf{s}$

(1) Whitney, Milton, U. S. D. A., Bu. of Soils Bul. No. 55, (1919), pp. $83,89-91$, and $169-188$, and soil map of U. S. accompanying it.

(2) Coffey, George Nelson, U. S. D. A., Bu. of Soils Bul. No. 85, (1912), pp. $38-41$.

(3) See Fig. 17.

(4) Thirteenth U. S. Census.

(5) The Small Farm Families had from 1 to 4.9 members, the Medium Farm ramilies had from 5 to 6.9 members, and the Large Farm Fam. ilies included those having from 7 to 9 persons each. 
few weeks out of the year. Nevertheless the table shows correlation between the size of farm family and number of cows kept for breeding and milk purposes.

In 1914 there were on the average 46 productive animal units per man and 46 crop-acres per man. This seems to show that man labor was unusually efficient with stock and crops. But as before stated this is largely due to extensive use of ranges for stock, and growing crops requiring but little man labor. It is also due in part to growing crops that permit of the use of machinery for most of the operations. There were 16 crop-acres per work horse here and only 14 at Hyde Park. The reasons for this apparent horse efficiency are the same as those stated above for man labor efficiency.

Beaver City is 32 miles from Milford, the nearest railway station, but there are good dirt-roads the year round. The main auto highway between Salt Lake City and Los Angeles, called the Arrowhead Trail, basses thru Beaver.

The greater part of the farm products are marketed or fed on the farm. Livestock, however, are driven to the railroad and shipped to Los Angeles, Salt Lake, Ogden, Kansas City, Omaha, or Chicago. Eggs and farm made butter are sold to general merchandise stores at Beaver and are taken by them in auto-trucks to Milford for shipment to Salt Lake and elsewhere. Some eggs and butter are sold in the mining camps near Beaver. Some cream is sold in Beaver and some in the mining camps. Th few surplus potatoes are shipped via Milford. The distance from the individual farms to Beaver Post Office varies from one-eighth to four miles so none of them are a great distance from a local market.

Of the 50 farms investigated in 1914,48 reported all or a part of the land operated as being owned by the operator, 4 reported some land cash-rented, and 5 reported some land share-rented. The average area per farm of the owned land was 174 acres and about 3 acres cash and 3 acres share rented, or 179 acres in the total farm area. The 4 farms reporting land rented for cash rented an average of 34 acres per farm or 136 acres in all. The 5 farms reporting land rented on shares rented 125 acres in all or 25 acres per farm.

The Thirteenth U. S. Census reports 319 farms in Beaver County having an average of 144.2 acres each. Of these farms 285 or 89.3 per cent were reported as operated by the owners, 28 by share tenants, 3 eash tenants, 2 managers, and 1 not specified.

The average value of land and buildings per acre was $\$ 43$ in 1915 . The average amount invested in real estate was $\$ 8,174$ and the working capital was $\$ 4,471$ on the average of 40 farms. Table XXIII shows that the value of Hyde Park land and buildings per acre was $\$ 106$, or about $21 / 2$ times as much as at Beaver. The low price of land and extensive farming go together. The high value of land is a result of the greater profitableness of the more intensive type of farming. Farmers cannot afford to do extensive farming on high priced land.

The facts given concerning water-tenure, water-rights, canal ownership and operatioin, and duty of water at Hyde Park also apply generally to Beaver. The irrigation practices are also similar in the two places.

Only 7 farms out of 50 investigated reported mortgages. The interest rates paid varied from 5 to 9 per cent. One farmer paid 5 per cent, 2 paid 6 per cent, 1 paid 7 per cent, 1 paid 8 per cent, and 2 paid 9 per cent interest on the money obtained by mortgaging. This is an average of 7.14 per cent interest paid by these farmers. Using 7.14 per cent as interest rate and the average labor income of the 50 farmers in 1914 was $\$ 92$. Using 5 per cent interest the labor income was $\$ 396$, using 5.5 per cent, labor income was $\$ 325$, using 8.6 per cent, labor income was minus $\$ 114$, and using 9 per cent labor income was minus $\$ 170$. The labor income was greater in 1915 than in 1914 , and greater 
in 1916 than in 1915 as shown by Tables III, IV, V, VI, and VII in Appendix. This was due largely to increase in prices of farm products.

In 1916 the average labor income of the farmers of this area was greater than the average labor income of the farmers of the Hyde Park area. This variation in labor income was undoubtedly due largely to the changes in the relative prices of farm products and to the variation in the successes and the failures in each area of the various crop and stock enterprises.

The type of farming at Beaver is more extensive than at Hyde Park largely because of climate, soil, markets, National Forest ranges and winter ranges, and competing farm enterprises. Livestock, cattle and sheep, are the principle enterprises because of distance to market and low cost of livestock production. Alfalfa and other hay are the principal crops grown because of cattle and some sheep requiring winter feed. Other crops grown here are not important.

\section{MONROE, SEVIER COUNTY, UTAH}

Monroe is in Sevier County, three miles from Elsinore, the nearest railway station. Elsinore is on the Marysvale Branch of the Denver and Rio Grande, or Rio Grande Western Railroad.

Monroe had a population of 1227 in 1910 . Here as at Hyde Park and Beaver most of the farm families live in town.

The elevation at Monroe is 5380 feet above mean sea level or about 900 feet higher than at Hyde Park.

In spite of the fact that Monroe is more than 200 miles farther south than Hyde Park the average length of the growing season is 110 days. or 40 days less and two weeks later than at Hyde Park. The mean annual temperature is $48^{\circ} \mathrm{F}$. or $0.5^{\circ} \mathrm{F}$. less than for Beaver and about $0.4^{\circ} \mathrm{F}$. greater than for Hyde Park. The average annual precipitation is 8.34 inches, only 3.84 inches of which fall from April 1 to September 30 . On this account dry-farming is not practised. All crops are irrigated. The average date of last killing frost in spring is May 28, as compared, with May 10 at Hyde Park.

This area is in the Great Interior Basin Soil Province. (See Fig. 15). A soil survey has been made in the Sevier Valley, the report of which gives a detailed description of the soils of this area (1).

The irrigation canals are owned and operated by the farmers who use the water. As in each of the areas already discussed there is here als 0 some low wet meadow and pasture land due to over irrigation and seepage water.

There is a sugar factory at Austin which is three miles north of Monroe. This factory makes it possible for Monroe farmers to groll sugar-beets. A cooperative cheese factory is situated at Monroe so that dairying is also developing here. One of the main auto roads of the State running north and south passes thru town. The wagon roads are usually in good condition. The distance from the farm to market for the most important product varies from one-half to seven miles.

Monroe is not as handicapped as Beaver respecting markets, nor is it quite as well situated as Hyde Park. But as with Beaver the main farm enterprises here are sheep and cattle because of the distance to any large market and the low cost of livestock feed. The special feature of this area is the raising of February lambs for the early Los Angeles market. (See Tables VIII to XII in Appendix). Los Angeles buyers are on the ground at selling time and usually pay fair prices for these early lambs.

Table XLV shows that at Monroe as at Hyde Park there is a direct

(1) Gardner, F. D., and Jensen, C. A., U. S. D. A., Bu. of Soils, Field Operations, $(1900)$. 
Table XLV.--Size of Family, Acres Sugar-beets Raised, and Cows Milked, Monroe, Sevier County, Utah, 1914

\begin{tabular}{|c|c|c|c|c|c|c|c|}
\hline 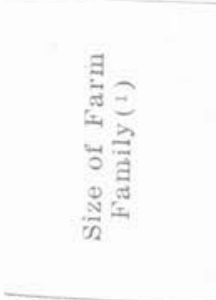 & 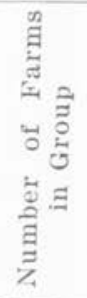 & 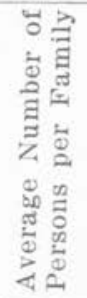 & 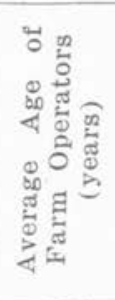 & 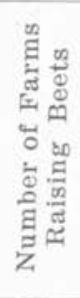 & 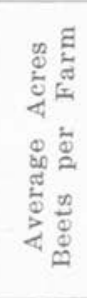 & 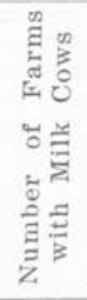 & 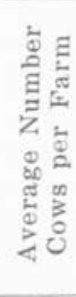 \\
\hline All Farms...... & 66 & 6.5 & 47.8 & 54 & 7.7 & 64 & 5.9 \\
\hline 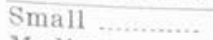 & 20 & 3.8 & 46 & 14 & 6 & 19 & 3 \\
\hline Medium ............ & 26 & 6.5 & 48 & 23 & 7 & 26 & 6 \\
\hline 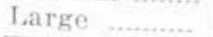 & 20 & 9.2 & 49 & 17 & 10 & 19 & 8 \\
\hline
\end{tabular}

correlation between the number in the farm family, the number of acres of sugar-beets raised, and the number of cows milked.

Table XLVI,-Tenure and Use of Farm Land per Farm, 66 Farms, Monroe, Sevier County, Utah, 1914

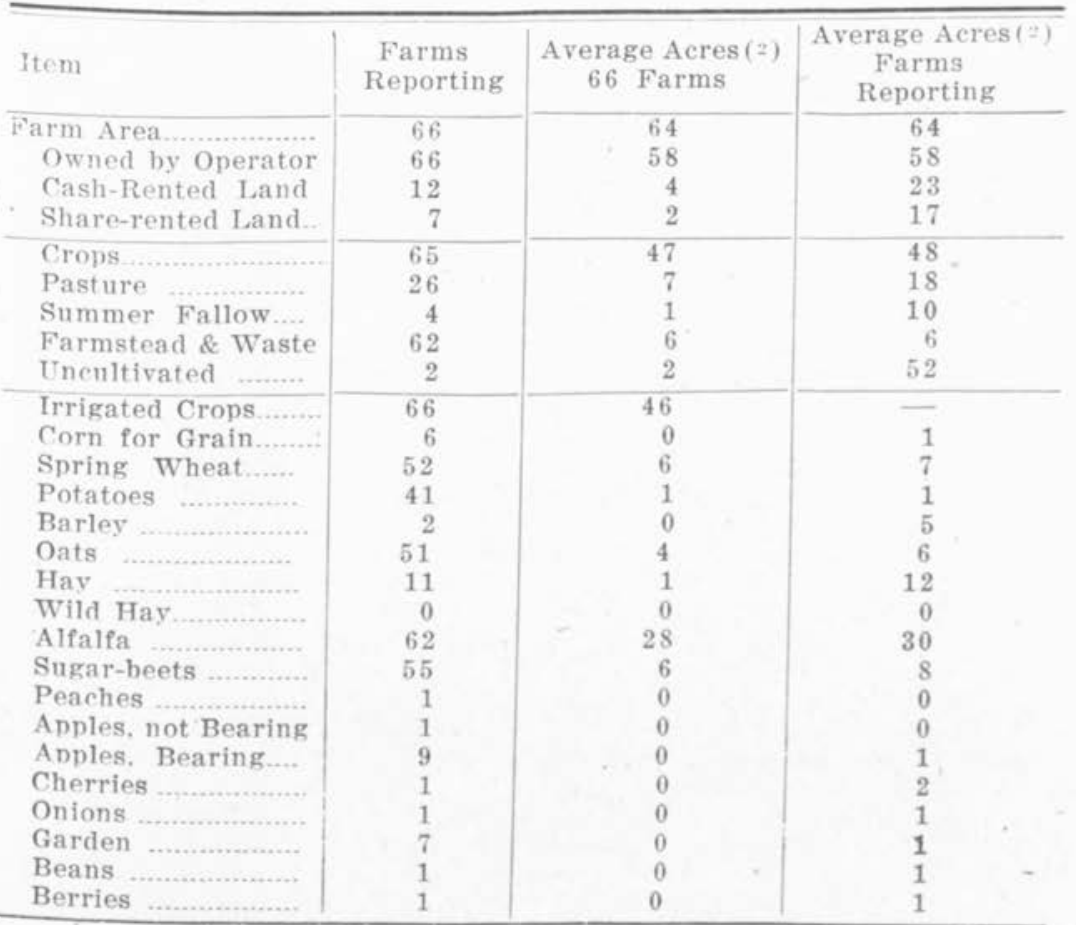

(1) The Small Farm Families had from 2 to 5.9 members, the Mefium Farm Families had from 6 to 7.9 members, and the Large Farm Families included those having from 8 to 13 persons each.

(2) Areas are given to the nearest acre. 
The most important sales are sheep and cattle. Sheep is by far the most important source of income. The reasons for the comparative im. portance of the sheep industry here are the isolation from large markets for cash crops and the convenience to summer range on the Fishlake and Fillmore National Forests and winter range on the Millard and Beaver County Deserts which make possible a low cost of production. Dairying and sugar-beet raising are becoming more important as markets for cheese are found that permit payment of sufficiently high prices for milk, and as prices for sugar-beets raise in proportion to the cost of production.

Based on acreage, the crops grown rank as follows: (1) alfalfa 1585 acres, (2) sugar-beets 403 acres, (3) spring wheat 329 acres, (4) oats 267 acres, (5) timothy and other hay 103 acres, (6) potatoes 51 acres, (7) rye 7 acres, (8) corn 3 acres, and (9) barley 2 acres. More than 61 per cent of the land was growing hay most of which was alfalfa. Sugar-beets and some wheat were grown as cash crops. Oats, rye, and harley were grown for feed. The potatoes and corn were grown for home use and to supply the local market.

The average labor income of the Monroe farmers in 1914 was $\$ 516$ with interest charged at 5 per cent, $\$ 363$ with interest at 5.5 per cent, $\$ 132$ with interest at 8.6 per cent, and $\$ 89$ with interest figured at 9 per cent.

In 1914 these farms were less profitable than those at Hyde Park and more profitable than those at Beaver. In 1915 and 1916 however, these farms were more profitable than either those at Hyde Park or those at Beaver. This variation in profitableness is undoubtedly due to variation in the success of producing crops and stock and also to the variations in the market prices of the farm products. The high prices of wool and meat nave made the war years very profitable for the Monroe farmers.

\section{SANDY, SALT LAKE COÚNTY, U'TAH}

Sandy is about 20 miles south of Salt Lake City. In 1910 it had a population of 1037. Draper is south of Sandy. The farm business records treated in this area were taken in the townships of Sandy, Draper, Midvale, Jordan, and West Jordan.

The elevation at Sandy is 4366 feet above mean sea level.

The normal annual precipitation is 16 inches, 7 of which fall in the crop-growing season. There are 89 days with 0.01 inch or more precipitation and the mean annual temperature is $51.40 \mathrm{~F}$. The number of rainy days, the amount of precipitation, and the mean annual tempersture are higher than for any other of the 8 areas in this study. As at Hyde Park, dry-farming is also practised here on land for which there is no irrigation water and on that which is poorly situated with reference to the water, provided the soil is of a character to produce profitable crops. The average growing season is 183 days, or is more than 30 days longer than in any other of the 8 areas. The average date of last killingfrost in the spring is April 19.

This area is in the Great Interior Basin Soil Province. There has been a detailed soil survey made in this valley (1) but not all of this ares was included in that survey. However, typical soils are described and ham gravelly loam. The soil types identified are Jordan sandy loam, Bingmeadows, Jordan , Jordan loam, Jordan clay and clay loam, Jordan farmers described sand, Bingham stony loam, and Salt Lake sand. The loam, clayey sandy loam, and clay, adobe clay, clay loam, sandy, sandy predominantly sandy and sandy lack sandy loam. At Sandy the soil is

Near the mountains it is coarser

(1) Gardner, F. D., and Stewart, John, U. S. D. A., Bu. of Soils, Field
perations, (1899). 
Table XLVII.- Tenure and Use of Farm Land per Farm, 72 Farms, Sandy, Salt Lake County, Utah, 1914

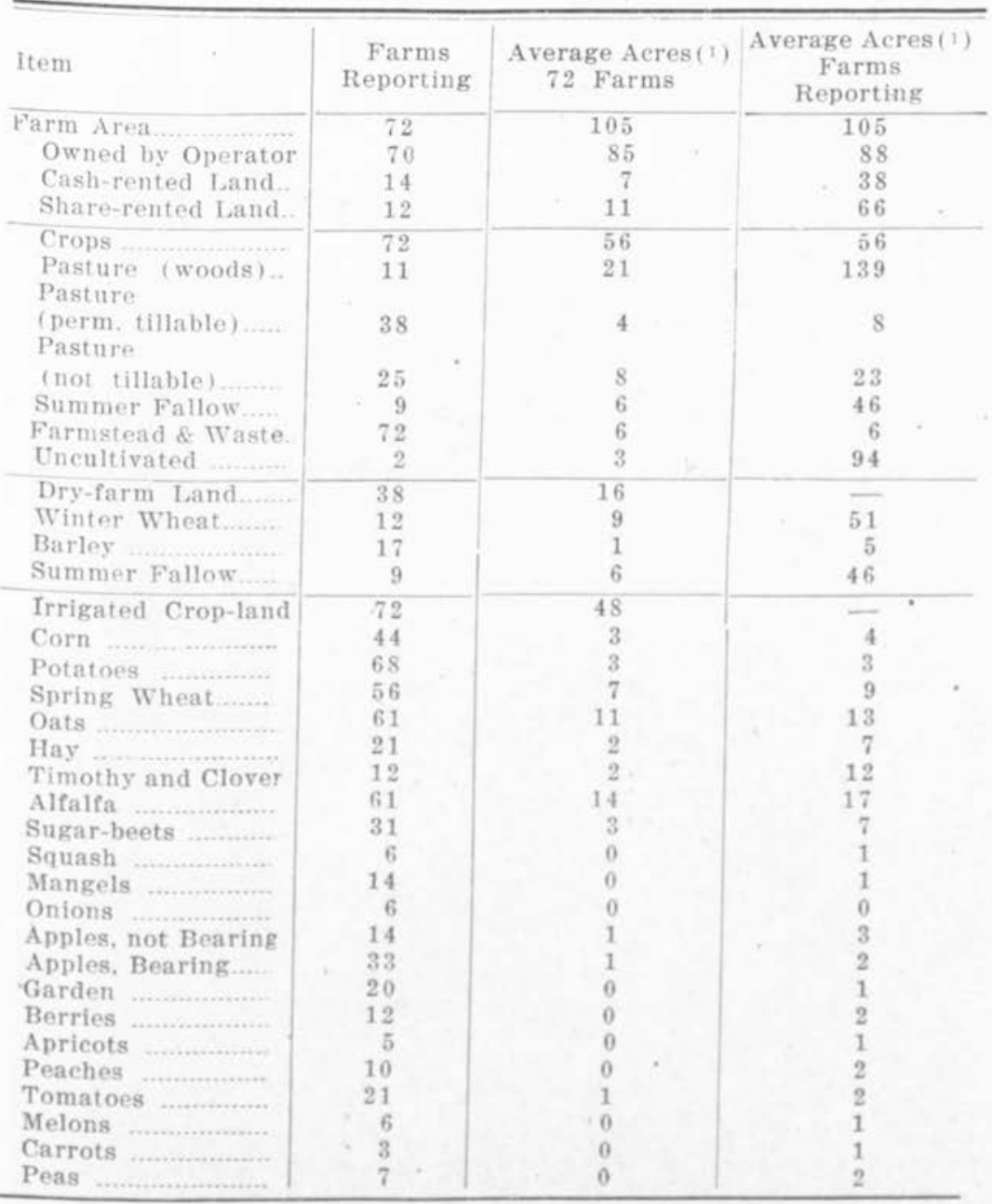

until at the base coarse gravel is found. When irrigated and well drained these soils are very fertile as evidenced by the crop yields. Some of the land is low and wet and crop yields are low on such fields.

Table XLVIII shows a direct correlation between the number in the farm families on the farm and the number of cows milked but does not show such correlation between size of family and number of acres of sugar-beets per farm.

One reason there is not much correlation here between the size of farm family and acres of sugar-beets is because two fairly young farmers are exceptional in that they have a business very much larger than the average in every way and they fall in the class with medium-sized 
Table XLVIII. - Size of Family, Acres Sugar-beets Raised, and Cows Milked, Sandy Area, Salt Lake County, Utah, 1914

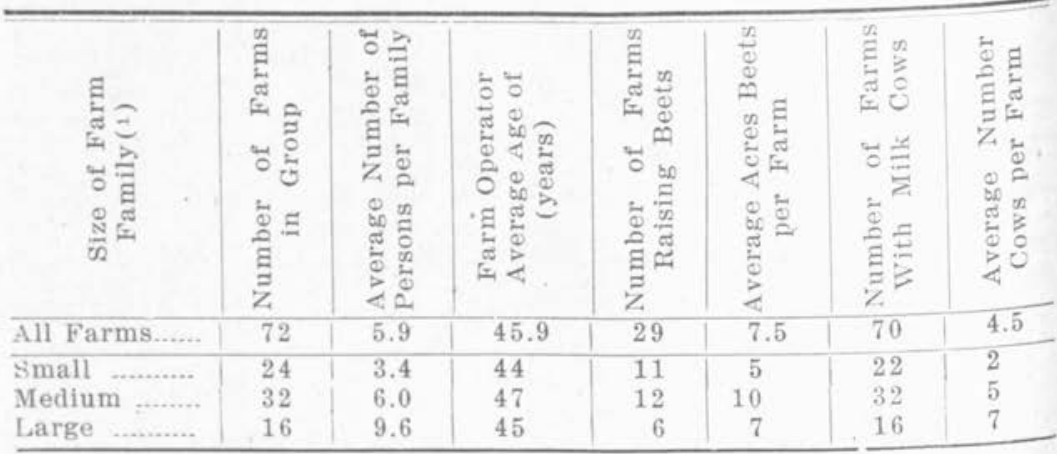

farm families. There are not enough farms in the experiment to overcome this abnormality.

There is a great variety of crop and stock enterprises included in this district. Because of the climatic, market, soil, water, and transportation conditions, a wide selection of enterprises is offered these farmers. Each farmer of the area has his own set of conditions and he attempts to meet them to his best advantage. Consequently there is a great diversity of practices. Some farmers sell market milk in Salt Lake City. Some ship milk to creameries, some ship to cheese factories, and a few make butter on the farm and sell it at retail. Some farmers raise hay for the Salt Lake City market while others raise it to feed their own stock and even buy hay and grain in addition. The surplus poultry and eggs are sold to laborers of the smelters, or to private parcel post customers in Salt Lake City, or to a store at Sandy, Draper, or elsewhere.

The average capital investment on 72 farms in 1914 was $\$ 15,828$, or Rreater than for any other area in this study in spite of the fact that there were only 100 acres per farm or fewer than for any area here investigated. The two main sources of income on these 72 farms were grain \$301, and "other livestock" (sheep, hogs, poultry, and bees), \$272. There was only one source of income which was equal to 10 per cent of the gross farm receipts and that was grain. There was an average of 7.8 crops grown per farm and 5.8 sources of income per farm. But in spite of sales of fruits, vegetables, sugar-beets, potatoes, grain, hay, straw, dairy products, cattle, horses, sheep and wool, hogs, poultry and eggs, honey, miscellaneous receipts, and increase in feed and supply inventory; yet the average labor income was a minus $\$ 102$. Ten farmers had an average labor income of $\$ 592$ the same year. There are two main reasons why these farms do not yield as large a labor income as the Hyde Park farms. While these farms have an excellent climate they have not quite as good soil as shown by the crop yields. The second reason is that land values on some of these farms are not based solely on their present agricultural productiveness but partake of the nature of real estate speculations and as such include a possible future agricultural value and also a possible future value as eity lots for residences. A third possible reason is that because of this speeulative feature and alsc because the speculators are attempting to farm the land themselves, the farmers, as farmers, are inferior to those at Hyde Park. There is no

(1)The Small Farm Families had from 1 to 4.9 members, the Medium Farm Families had from 5 to 7.9 members, and the Large Farm Families included those from 8 to 14 persons each. 
doubt, however, that if one could get the actual increase in the value of land from year to year and add it to labor income one would find that these farmers were doing very well by holding the land for the rise in value and that the total farm profits are normal. (See Tables XIII to XVII in Appendix.)

\section{FERRON, EMERY COUNTY, UTAH}

In 1910 Ferron had a population of 651 .

The elevation is 5500 feet above mean sea level.

Table IL.-Tenure and Use of Farm Land per Farm, 38 Farms, Ferron, Emery County, Utah, 1914

\begin{tabular}{|c|c|c|c|}
\hline !tem & $\begin{array}{c}\text { Farms } \\
\text { Reporting }\end{array}$ & $\begin{array}{c}\text { Average Acres (1) } \\
38 \text { Farms }\end{array}$ & $\begin{array}{c}\text { Average Acres(1) } \\
\text { Farms } \\
\text { Reporting } \\
\end{array}$ \\
\hline Farm Area................... & 38 & 106 & 106 \\
\hline Owned by Operator & 37 & 81 & 83 \\
\hline Cash-rented Land.. & 5 & 5 & 39 \\
\hline Share-rented Land.. & 8 & 17 & 80 \\
\hline Crops & 38 & 51 & 51 \\
\hline Pasture (woods).... & 1 & 0 & 4 \\
\hline Pasture (tillable).. & 20 & 9 & 17 \\
\hline Pasture (not ". ... & 16 & 11 & 25 \\
\hline Fallow & 10 & 3 & 12 \\
\hline Farmstead \& Waste & 37 & 21 & 22 \\
\hline Uncultivated ........... & 8 & 11 & 51 \\
\hline Irrigated Crops.......... & 38 & 52 & - \\
\hline Corn & 18 & 1 & 2 \\
\hline Potatoes & 27 & 1 & 1 \\
\hline Spring Wheat............ & 35 & 9 & 10 \\
\hline Winter Wheat........ & 1 & 0 & 2 \\
\hline Barley & 13 & 1 & 2 \\
\hline Oats & 36 & 9 & 9 \\
\hline Hay & 11 & 6 & 20 \\
\hline Wild Hay.................. & 8 & 2 & 12 \\
\hline Alfalfa & 32 & 19 & 22 \\
\hline Beets & 1 & 0 & 0 \\
\hline Beans ….............. & 2 & 0 & 7 \\
\hline Carrots & 3 & 0 & 0 \\
\hline Mangels .... & 7 & $\theta$ & 1 \\
\hline Apples, Bearing.... & 20 & 2 & 3 \\
\hline Seed Crops................. & 12 & 1 & 4 \\
\hline Garden & 7 & 0 & 1 \\
\hline Peaches & 1 & 0 & 2 \\
\hline Berries ............. & 1 & 0 & 0 \\
\hline Cherries ..................... & 1 & 0 & 0 \\
\hline Mixed Orchard..... & 9 & 1 & 3. \\
\hline Squash ..................... & 1 & 0 & 0 \\
\hline
\end{tabular}

The normal annual precipitation is 9 inches, 5 of which fall in the growing season. The precipitation has varied from 3 to 13 inches annually. There are on the average only 37 days annually with 0.01 inch of precipitation. It is necessary to irrigate all crops in this area.

Ranges are poor because of this low precipitation. The mean annual temperature is $46.10 \mathrm{~F}$. There are only 107 days in the average growing season, June 2 to September 17.

(1) Areas are given to the nearest acre. 
The soil is not so good here as in the Hyde Park area. Ferron is in the Rocky Mountain Valleys, Plateaus, and Plains Soil Province $\left({ }^{(1)}\right.$. (See Figure 15). This soil is fairly fertile, however, as shown by the crops produced. The soil and climate slightly handicap this area in comparison with Hyde Park. Market conditions are of first importance in determining the general type of farming here.

Table IL shows the tenure and use of land at Ferron in 1914. The important crops are feed crops.

Ferron is about 45 miles from Price, the railroad town where some of the farm and range products from this district are marketed or loaded for shipment to market. Range cattle are the chief source of income. Some cattle are grazed on the Manti National Forest but most of them are grazed on the prairies or plateaus south, east, and west of Ferron. These range cattle are fed in winter and raising feed is an important part of the farming operations in summer. The available winter range has too severe a climate for cattle and sheep so they must be fed all winter. Some farmers let the cattle stay out so long that severe storms often cause great losses from cold and starvation. A few farmers have been fairly successful with bees.

Table L.-Size of Farm Family and Number of Milk and Beef Cows Kept, Ferron, Emery County, Utah, 1914

\begin{tabular}{|c|c|c|c|c|c|c|}
\hline 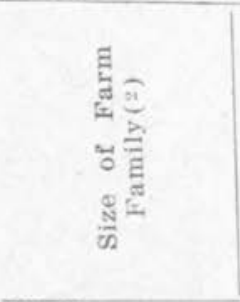 & 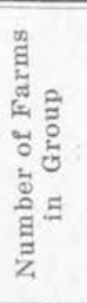 & 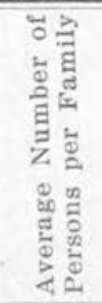 & 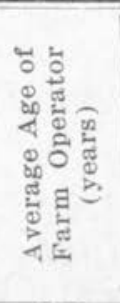 & 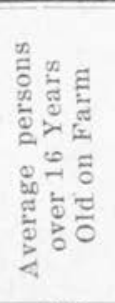 & 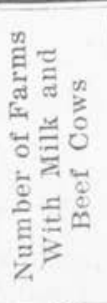 & 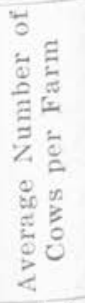 \\
\hline All Farms......... & 40 & 5.8 & 47.7 & 3.2 & 38 & 7.4 \\
\hline Small ................ & 14 & 2.9 & 45.2 & 2.4 & 14 & 6.3 \\
\hline Medium ............. & 12 & 5.7 & 49.4 & 3.0 & 10 & 10.1 \\
\hline Large ................... & 14 & 8.8 & 48.9 & 4.2 & 14 & 6.5 \\
\hline
\end{tabular}

Fruits, such as apples, plums, and small bush fruits; vegetables; and melons are the main cash crops grown here. They are marketed at Sunnyside, Hiawatha, Scofield, and other mining eamps that are from 40 to 60 miles distant and also at the stores in Ferron. Peddlers gather vegetables, fruits, farm butter, and meat from the farmers and sell them in the camps. Several farmers from whom business records were obtained had peddled during many summers. This peddling was the most important single item included in their miscellaneous receipts.

Hay and grain are also sold to some extent. Hay is usually baled and hauled to the camps or fed to a neighbor's cattle or sheep. Sugarbeets cannot be grown extensively because there is no sugar factory near. Dafrying is limited because of a lack of market for dairy products. Not much care is given fruit trees because of the uncertainty of market and weather. A market as narrow as this cannot be satisfactory.

The type of farming followed seems, in general, well adapted to the conditions. The average labor income in 1914 was $\$ 117$ and the aver-

(1) Whitney, Milton, U. S. D. A., Bu. of Solls, Bul. No. 55, (1909), gives a detailed description of these soils.

(2) The Small Farm Families had from 2 to 4.9 members, the Medium Farm Families had from 5 to 7.9 members, and the Large Farm Fam. ilies included those having from 8 to 12 persons each. 
age for the 10 better-paying farms was $\$ 785$. The average of all farms in 1915 was $\$ 119$, and in 1916 it was $\$ 412$. (See Tables XVIII to XXI! in Appendix).

Table L shows that there were 5.8 persons per family on the farms at Ferron, and that the average age of the farm operators was 47.7 years. This table does not show a very decided correlation between the size of the farm family and the average number of cows per farm. This may be due to the fact that there are not enough farms in each group as given in the table to establish a normal for each group. It is undoubtedly affected by the fact that many of the cows listed as milk cows are nothing more than range cows, which have been milked for only short periods.

\section{WELLINGTON, CARBON COUNTY, UTAH}

Wellington had a population of 358 in 1910 , and is situated about 12 miles southeast of Price on the Denver and Rio Grande Railroad. The clevation is 5540 feet above mean sea level. The precipitation is only 7 inches, of which but 4 inches fall from April 1 to September 30 .

Table LI. - Tenure and Use of Farm Land per Farm, 26 Farms, Wellington, Carbon County. Utah, 1914

\begin{tabular}{|c|c|c|c|}
\hline Item & $\begin{array}{c}\text { Farms } \\
\text { Reporting }\end{array}$ & $\begin{array}{c}\text { A verage Acres (1) } \\
26 \text { Farms } \\
\end{array}$ & $\begin{array}{c}\text { Average Acres (1) } \\
\text { Farms } \\
\text { Reporting }\end{array}$ \\
\hline 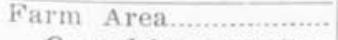 & 26 & 117 & 117 \\
\hline Owned by operator & 25 & 92 & 96 \\
\hline Cash-rented Land. & 3 & 24 & 212 \\
\hline Share-rented Land & 1 & 1 & 20 \\
\hline Crops ……................ & 26 & 50 & 50 \\
\hline Pasture (woods).. & 1 & 4 & 100 \\
\hline Pasture (Tillable).. & 7 & 2 & 8 \\
\hline Pasture (not ")... & 4 & 2 & 16 \\
\hline Summer Fallow.... & 7 & 4 & 15 \\
\hline Farmstead \& Waste & 26 & 29 & 29 \\
\hline Uncultivated ......... & 10 & 30 & 77 \\
\hline Irrigated Land......... & 26 & 49 & $\overline{0}$ \\
\hline Corn & 16 & 2 & 3 \\
\hline Potatoes & 24 & 3 & 3 \\
\hline Spring Wheat... & 13 & 2 & 4 \\
\hline Winter Wheat........ & 1 & 0 & 2 \\
\hline 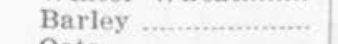 & 10 & 2 & 4 \\
\hline Oats & 17 & 5 & 8 \\
\hline Hay & 10 & 5 & 14 \\
\hline Alfalfa & 22 & 29 & 34 \\
\hline Beets & 2 & 0 & 1 \\
\hline Mangels ................... & 5 & 0 & 0 \\
\hline Seed Crops.............. & 2 & 1 & 12 \\
\hline Tomatoes .................. & 1 & 0 & 1 \\
\hline Beans & 3 & 0 & 0 \\
\hline Cabbage & 8 & 0 & 1 \\
\hline Apples, Bearing...... & 6 & 0 & 1 \\
\hline Garden ……........... & 10 & 0 & 1 \\
\hline Turnips ......................... & 1 & 0 & 1 \\
\hline Berries ….............. & 3 & 0 & 0 \\
\hline Mixed Orchard.......... & 2 & 0 & 0 \\
\hline
\end{tabular}

(1) Areas are given to the nearest acre. 
The climate, soil, topography, camp markets, and type of farming are very similar to the conditions at Ferron, Emery County.

Table LI shows the tenure and use of farm land in this area. At Wellington, alfalfa is the main crop.

Table LII shows the relation of size of farm family to the number of cows per farm.

Table LII. - Size of Family and Milk Cows Kept, Wellington, Carbon County, Utah, 1914

\begin{tabular}{|c|c|c|c|c|c|}
\hline 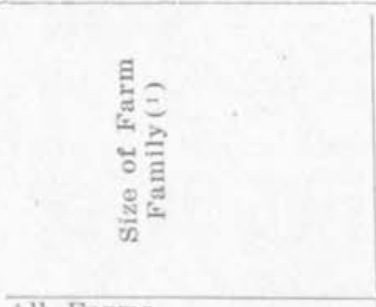 & 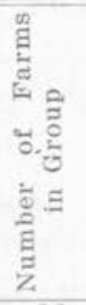 & 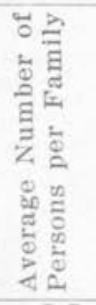 & 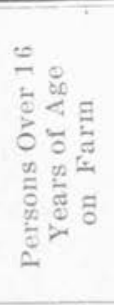 & 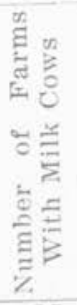 & 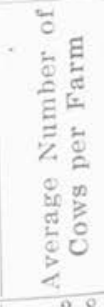 \\
\hline All Farms............................... & 26 & 5.7 & 2.8 & 25 & 2.8 \\
\hline Small ….............................. & 8 & 2.3 & 2.0 & 8 & 2.1 \\
\hline (1) & 9 & 5.5 & 2.5 & 9 & 2.6 \\
\hline 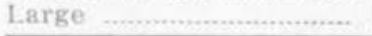 & 9 & 8.8 & 3.6 & 8 & 3.8 \\
\hline
\end{tabular}

The age of the farm operator was omitted because no record was obtained. There is correlation here between the number of persons in the farm family on the farm. and the number of cows kept. This seems to be true in all areas where the number of milk cows was accurately taken.

More livestock are raised here than at Ferron and more sheep in proportion to cattle, otherwise the two are about the same. The average labor income of the 26 Wellington farmers in 1914 was $\$ 165$. The sverage farm capital was $\$ 8391$, and therefore interest at 8 per cent was \$671. (See Tables XVIII to XXII in Appendix).

\section{HINCKLEY, MILLARD COUNTY, UTAH}

Hinckley is situated in Millard County about 6 miles north and west of Oasis, which is tne nearest railway station.

The 1910 U. S. Census gives the population of Hinckley as 553 .

The elevation is 4541 feet above mean sea level.

The normal annual precipitation is 8 inches only 4 of which fall in the crop-growing season. Because of this slight rainfall dry-farming is not practised. All crops are irrigated and ranges are poor. However, considerably more rain than this falls in the mountains to the east. But they are too far away from Hinckley to be grazed by Hinckley stock.

This area is in the Great Interior Basin Soll Province, (See Figure 15). The soll is not so fertile as at Hyde Park and is more inclined to be elkaline. Clay and clay loam predominate altho there is some sandy loam reported. The land in general is flat. Often it is too flat to irrigate conveniently. When such is the case underground drainage is poor and often alkali spots appear.

(1) The Small Farm Families had from 1 to 4.9 members, the Medium Farm Families had from 5 to 6.9 members, and the Large Farm Families included those having from 7 to 11 persons each. 
Table LIII shows direct correlation between size of family and cows per farm.

Table LIII. - Size of Farm Family and Number of Milk Cows Kept, Hinckley, Millard County, Utah, 1914

\begin{tabular}{|c|c|c|c|c|c|c|}
\hline 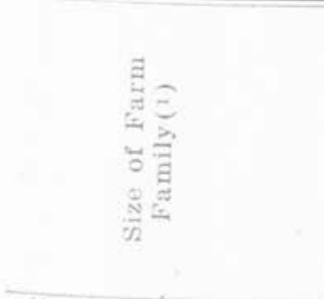 & 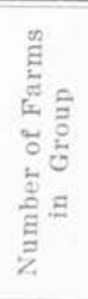 & 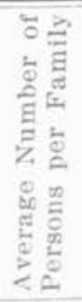 & 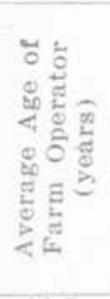 & 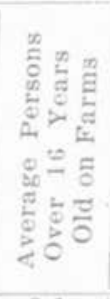 & 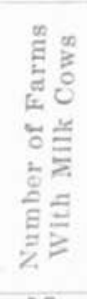 & 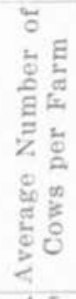 \\
\hline A11 Farms & 59 & 6.6 & 43.5 & 3.1 & 57 & 4.5 \\
\hline 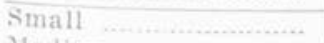 & 19 & 3.8 & 37.7 & 2.1 & 18 & 3.4 \\
\hline $\begin{array}{l}\text { Medium } \\
\text { Large }\end{array}$ & $\begin{array}{l}25 \\
15\end{array}$ & 7.2 & 45.0 & $\begin{array}{l}2.7 \\
5.0\end{array}$ & $\begin{array}{l}25 \\
14\end{array}$ & $\begin{array}{l}4.4 \\
6.0\end{array}$ \\
\hline
\end{tabular}

Table LIV. - Tenure and Use of Farm Land per Farm, 59 Farms, Hinckley, Millard County, Utah, 1914

\begin{tabular}{|c|c|c|c|}
\hline Item & $\begin{array}{c}\text { Farms } \\
\text { Reporting }\end{array}$ & $\begin{array}{c}\text { Average Acres }(z) \\
59 \text { Farms }\end{array}$ & $\begin{array}{c}\text { Average Acres (2) } \\
\text { Farms } \\
\text { Reporting }\end{array}$ \\
\hline $\begin{array}{l}\text { Farm Area............ } \\
\text { Owned by Operator } \\
\text { Cash-rented Land.. } \\
\text { Share-rented Land }\end{array}$ & $\begin{array}{r}59 \\
58 \\
1 \\
6\end{array}$ & $\begin{array}{r}152 \\
145 \\
3 \\
5\end{array}$ & $\begin{array}{r}152 \\
148 \\
186 \\
46\end{array}$ \\
\hline $\begin{array}{l}\text { Crops ........ } \\
\text { Pasture (woods).. } \\
\text { Pasture (Tillable).. } \\
\text { Pasture (not .. ... } \\
\text { Summer Fallow...... } \\
\text { Farmstead \& Waste } \\
\text { Uncultivated .......... }\end{array}$ & $\begin{array}{r}5 y \\
14 \\
18 \\
7 \\
22 \\
59 \\
35\end{array}$ & $\begin{array}{r}52 \\
11 \\
8 \\
6 \\
5 \\
9 \\
61\end{array}$ & $\begin{array}{r}52 \\
46 \\
27 \\
50 \\
13 \\
9 \\
103\end{array}$ \\
\hline 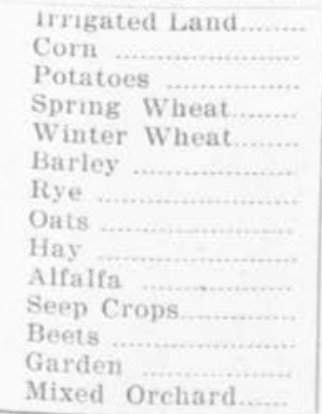 & $\begin{array}{r}59 \\
24 \\
19 \\
36 \\
18 \\
3 \\
9 \\
21 \\
8 \\
56 \\
4 \\
3 \\
4 \\
3\end{array}$ & $\begin{array}{r}51 \\
1 \\
0 \\
7 \\
3 \\
0 \\
1 \\
2 \\
3 \\
34 \\
0 \\
0 \\
0 \\
0\end{array}$ & $\begin{array}{r}-2 \\
1 \\
11 \\
11 \\
6 \\
7 \\
7 \\
22 \\
36 \\
5 \\
3 \\
1 \\
0\end{array}$ \\
\hline
\end{tabular}

(1) The Small Families had from 2 to 5.9 members, the Medium Farm Families had from 6 to 8.9 members, and the Large Farm Families included those having from 9 to 11 persons each.

(2) Areas are given to the nearest acre. 
At the time these records were taken there was no sugar factory in this distriet; therefore no sugar-beets were grown. Dairying was limited because of market conditions, the great distance to haul cream, etc. Some farmers milk a few cows and the farm families make butter which is sold at the town stores or traded there for groceries. Some poultry and eggs are also traded for groceries.

Table LIV shows the tenure and use of farm land at Hinckley. The main sources of income on the average are (1) alfalfa seed, (2) alfalfa hay and other hay, and (3) cattle. The average receipts from each of these respectively were in 1914 , alfalfa seed $\$ 340$, hay $\$ 244$, and cattle \$186. The growing of alfalfa seed on most of the farms of this area is quite a gamble. On a few farms a fairly good crop is obtained each year. When a crop of seed is obtained the farmer makes a very good labor income but when the crop is left for seed and the seed fails little use can be made of it and labor income in such cases is sometimes a minus quantity. Some grain is sold and a few surplus potatoes are raised in normal years. In short, Hinckley is a distinct and separate community of farmers. The area feeds itself but its clothes, household-goods, and other necessaries it must purchase outside of the community. It pays for these purchases largely with alfalfa seed, hay, eattle, farm butter, surplus cggs, farm dressed pork, a few horses, and personal services.

The type of farming followed is fairly well adapted to the conditions and is moderately profitable. The average labor income of 59 farmers in 1914 was \$323. The same year there were ten farmers who had an average labor income of $\$ 1403$. The average labor income in 1915 was $\$ 104$, and in 1916 it was $\$ 468$. (See Figures 1 to 21 in the Text, and Tables XXIII to XXVII in Appendix).

\section{PLEASANT GROVE, UTAH COUNTY, UTAH}

Pleasant Grove had a population of 1618 in 1910.

The elevation is $\mathbf{4 5 3 2}$ feet above mean sea level.

The normal annual precipitation is 15 inches(1), 6 of which fall in the growing season. The absolute lowest annual precipitation recorded is 9 inches and the absolute highest precipitation recorded is 22 inches. There are on the average 66 days annually with 0.01 inch or more precipitation. Dry-farming is successfully practiced here. The principle dry-farm crops are wheat and alfalfa. The mean annual temperature is $49.7 \circ \mathrm{F}$. This is . higher than for Hyde Park but lower than for Sandy. The warmest temperature recorded in any of the 8 areas is $105^{\circ} \mathrm{F}$. and that was recorded for this area. The avergae crop-growing season has 145 days, or a few less than Hyde Park and 35 to 40 less than Sandy, although situated further south than either of these districts. The average date of last killing frost in spring is May 12, or about the same as for Hyde Park but a little earlier than Beaver and much later than Sandy. The absolute latest date of killing frost in spring is June 29, or about the same as at Hyde Park and Monroe. The climate here is affected by Utah Lake.

This area is situated in the Great Interior-basin Soil Province. A detailed soil survey has been made of the area (2). The following soil types are distinguished: Maricopa stony loam, Caricopa gravelly loam, Jordan clay, Fresno sand, Jordan loam, Jordan sandy loam, Salt Lake loam, and

(1) There is no U, S. Weather Bureau Station at Pleasant Grove. The information given here is recorded for Provo which is the station having a climate very similar to Pleasant Grove and is situated in the township Just south of the Pleasant Grove township.

(2) Sanchez, Alfred M., U. S. D. A., Bu. of Solls, Field Operations. (1903). 
the gravel areas. These same soil types, except one, are found in Sait Lake county and are among those identified in the Sandy area. The best sugar-beet soil is the Jordan sandy loam, and the Jordan loam is the second best soil for this crop.

Most of the irrigation water is taken out of American Fork Creek but it is inadequate to irrigate the land of the area. Considerable land west of Pleasant Grove is irrigated by flowing wells. A small creek enters the valley east of Pleasant Grove, and furnishes irrigation water for some of the farms of this area.

The railroad transportation facilities are good. The San Pedro, Los Angeles, and Salt Lake Railroad and the Rio Grande Western traverse the area from north to south. The electric interurban road from Preston, Idaho, thru Logan, Brigham City, Ogden and Salt Lake City, runs thru Pleasant Grove to Provo. There are good auto roads running north, east, south, and west from the town. Sugar-beets are shipped from here to the Lehi factory.

The Wasatch National Forest to the east of town offers splendid grazing for cattle and sheep for about 8 months during the year. More cattle than sheep were kept on this range during the past few years because they have been more profitable(1). In many respects the conditions here are similar to those at Hyde Park.

Table LV.-Size of Family, Acres of Sugar-beets Raised, and Cows Milked, Pleasant Grove, Utah County, Utah, 1916

\begin{tabular}{|c|c|c|c|c|c|c|c|}
\hline 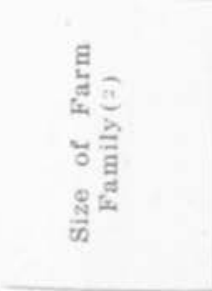 & 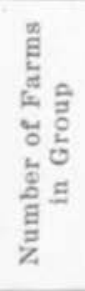 & 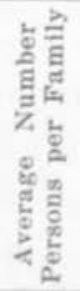 & 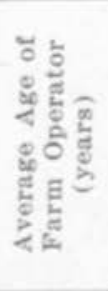 & 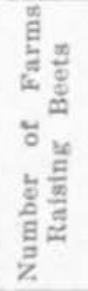 & 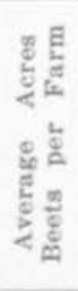 & 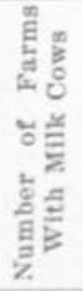 & 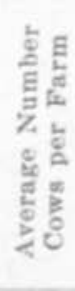 \\
\hline All Farms...... & 56 & 5.8 & 43.3 & 41 & 6.2 & 55 & 4.8 \\
\hline Small ……........ & 13 & 3.0 & 44.0 & 10 & 6 & 13 & 6 \\
\hline Medium & 26 & 4.7 & 43.0 & 19 & 5 & 25 & 4 \\
\hline Iarge ................. & 17 & 8.4 & 43.0 & 13 & 8 & 17 & 6 \\
\hline
\end{tabular}

Table LV does not show a very striking direct correlation between size of farm family, acres of sugar-beets per farm, and number of cows per farm. This may in part be due to the new farms included in the small and large family groups, also to the lack of carefully distinguishing between the milk and range cows.

Table LVI shows the tenure and use of land in the Pleasant Grove area.

Table XXVIII in the appendix shows that the land on the average farm was valued at $\$ 5,019$, the buildings $\$ 1,235$, livestock $\$ 892$, machinery $\$ 350$, and feed and supplies $\$ 296$, making a total capital per farm of $\$ 7,792$. The sources of income in the order of importance were in 1916 ,

(1)Third Annual Report, Utah State Bu. of Immigration, Labor and Statistics, 1917 , p. 185.

(2)The Small Farm Families had from 1 to 4.9 members, the Medium Farm Families had from 5 to 6.9 members, and the Large Farm Families included those having from 7 to 12 persons each. 
Table LVI. - Tenure and Use of Farm Land per Farm, 56 Farms, Pleasant Grove, Utah County, Utah, 1916

\begin{tabular}{|c|c|c|c|}
\hline Iten & $\begin{array}{c}\text { Farms } \\
\text { Reporting }\end{array}$ & $\begin{array}{c}\text { Average Acres (1) } \\
56 \text { Farms }\end{array}$ & $\begin{array}{c}\text { Average Acres }\left({ }^{1}\right) \\
\text { Farms } \\
\text { Reporting }\end{array}$ \\
\hline Farm Area & 56 & 68 & 68 \\
\hline Owned by Operator & 56 & 54 & 54 \\
\hline Cash-rented Land... & 11 & 6 & 31 \\
\hline Share-rented Land.. & 15 & 8 & 28 \\
\hline Crop Area................... & 56 & 35 & 38 \\
\hline Pasture (woods) & 11 & 13 & 65 \\
\hline Pasture (Perm. till.) & 23 & 4 & 11 \\
\hline Pasture (not " ) & 13 & 3 & 13 \\
\hline Summer Fallow...... & 7 & 3 & 19 \\
\hline Farmstead \& Waste & 53 & 4 & $\begin{array}{r}19 \\
4\end{array}$ \\
\hline Uncultivated ........ & 5 & 4 & $\begin{array}{r}4 \\
40\end{array}$ \\
\hline Dry-farm Land...... & 28 & 6 & - \\
\hline Winter Wheat...... & 14 & 2 & 9 \\
\hline 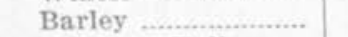 & 17 & 1 & 3 \\
\hline Summer Fallow... & 7 & 3 & 19 \\
\hline Irrigated Crop Land & 56 & 33 & - \\
\hline Beans …........................ & 6 & 0 & 1 \\
\hline Corn & 32 & 2 & 3 \\
\hline Potatoes ..................... & 48 & 1 & 1 \\
\hline Spring Wheat......... & 44 & 4 & 5 \\
\hline Oats & 41 & 3 & 4 \\
\hline Hay ........................... & 30 & 5 & 10 \\
\hline Alfalfa & 48 & 10 & 12 \\
\hline Seed Crons............... & 2 & 0 & 2 \\
\hline 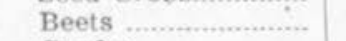 & 43 & 5 & 6 \\
\hline Garden & 9 & 0 & 0 \\
\hline Apples, Bearing.... & 35 & 1 & 2 \\
\hline - Apples, not Bearing & 9 & 1 & 8 \\
\hline Mixed Orchard......... & 33 & 1 & 2 \\
\hline Berries ....................... & 17 & 0 & 1 \\
\hline Peas .............. & 5 & 0 & 1 \\
\hline
\end{tabular}

sugar-beets $\$ 298$, Cattle sales $\$ 186$, miscellaneous receipts $\$ 178$, dairy products $\$ 170$, grain $\$ 141$, potatoes $\$ 133$, fruit $\$ 126$, increase in feed and supply inventory $\$ 87$, swine sales $\$ 82$, poultry and eggs $\$ 57$, increase in livestock inventory $\$ 56$, hay $\$ 41$, horse sales $\$ 36$, increase in machinery inventory $\$ 24$, other crop sales $\$ 18$, increase in inventory of land and buildings $\$ 13$, and sheep sales $\$ 2$, a total of $\$ 1,649$ from 17 sources. The farm expenses amounted to $\$ 608$ and labor income $\$ 418$. There have been a number of publications dealing with the type of farming in this valley. four of these deal with the Provo Area only, but much of the information is applicable to Pleasant Grove(2). (See Table XXVIII in Appendix).

(1) Areas are given to the nearest acre.

(2) Thompson, E. H., and Dixon, H. M., U. S. D. A., B. P. I. Bul. No. 117. (July, 1914); Connor, L. G., U. S. D. A. Farm Mgt. Bul. No. 582 , (Jan,. 1918); Connor, L. G., Utah Agr. Exp. Sta. Bul. No. 165. (Oct., 1918 ) Moorhouse, L. A. and Others, U. S. D. A. Farm Mgt. Bul. No. 693 , (July,1918). 


\section{GENERAL SUMMARY}

1. Type of farming as here used means kind or example of farming.

2. The ideal type of farming for any community at any one time is that which combines crops, livestock, machinery, buildings, land, water, labor, and management of such kinds and grades, and in such amounts. numbers and proportions, and in such ways as to yield the highest longtime average net returns per unit of management or per manager.

3. Types of farming compete with each other on farms as do also individual crop and stock enterprises and the experiences of farmers tend to establish that type which is best suited to each farm and each district.

4. It is difficult in many cases to change readily from one type of farming to another.

5. The type of farming most profitable in a community this year may not be the best a few years from now because of varying economic conditions.

6. It is in the inter-relations of all the factors both natural and economic that the type of farming for any community or any particular farm is determined and as a rule that found in any community which has been settled for 50 years or more is not far from what it should be.

7. The purpose of this investigation is to show some of the inter-relations of the natural and economic factors as they affect some types of farming in Utah.

8. The original data here presented were collected by the writer and assistants during the years 1914,1915 , and 1916 , when he was in the employ of the United States Department of Agriculture and the Utah Agricultural College.

9. The Survey Method was used in collecting these data.

10. A study of type of farming has the following phases:

(1) Enumeration and description of the individual crop and stock enterprises.

(2) Determination of the magnitude and importance of each separate enterprise.

(3) Determination of the combinations of the enterprises.

(4) Determination of the proportions in which the enterprises are combined.

(5) Analysis of the factors affecting the choice of the enterprises and their combinations.

\section{HYDE PARK, CACHE COUNTY, UTAH}

11. Hyde Park is in Cache Valley in Cache County in the northcentral part of Utah. level.

12. The elevation at Hyde Park is abcut 4,507 feet above mean sea

13. Hay is the principal feed crop of the area and is used for dairy cows, young stock, and work horseg. On the average farm of the area there are 13 acres of alfalfa and only 7 acres of other hay. Oats are also grown for feed. Sugar-beets, dry-farm wheat, and barley are the cash crops. Potatoes are grown for farm-home use and to supply the local market. There was not much change in type of farming during the three years of this investigation. The wet low-lands are pastured or are in meadow. Some of the foothills are also pastured. Thus climate, irrigation, and drainage have determined location and extent of pasture.

14. It is largely on account of the pasture conditions at Hyde Park that dairying is so important in this district. Park.

15. Wheat is a more profitable dry-farm crop than barley at Hyde 
16. The reasons why alfalfa is grown on land suited for sugar-beets are:

(a) Alfalfa is needed for livestock feed.

(b) Alfalfa gives a better labor distribution.

(c) Alfalfa makes it possible to do some productive work in winter.

(d) It saves paying out an excessive amount of wages for hired help in summer.

(e) Alfalfa is needed in the crop rotation.

(f) The combination consequently nets a greater annual income.

17. Oats and spring wheat are both grown for the following reasons:

(a) Oats are grown mainly for horse feed.

(b) Spring wheat is grown on irrigated land as a cash crop.

(c) Growing both gives a better labor distribution.

(d) Alternating the two gives higher yields.

(e) Wheat on alfalfa sod before sugar-beets allows alfalfa roots and crowns to decompose to a greater extent, which facilitates beet culture the following year.

(f) Growing both saves labor or uses it more productively, gives better crop yields, helps in the culture of beets, and consequently increases the net annual income.

18. The reasons why 9 to 10 acres of beets are grown and less than 1 acre of potatoes on the average Hyde Park farm are as follows:

(a) These two crops compete for land, labor, capital, and management.

(b) Ten or 11 acres of these intensive crops are about all the average farm family can handle conveniently.

(c) A greater use of unpaid family labor may be utilized to advantage on the sugar-beet crop and the acres raised varies directly as the number in the farm family on the farm.

(d) The soil at Hyde Park is better adapted to beets than to potatoes.

(e) The potato market is practically limited to the local demand, while sugar, the final product of beets, competes on the world markets.

(f) The sugar factory companies contract in advance of planting time to pay the farmers a definite price per ton for the beets, which certainty of price takes much risk from the farmer and makes farming more stable.

(g) Potatoes are grown only for home use and the local market and 1 acre is sufficient to supply this demand.

(h) It is because of the above conditions that some beets and potatoes are grown at Hyde Park.

(i) Because of these conditions beets are on the average more profitable, and nine or ten times as many acres are devoted to the erop as are devoted to potatoes.

19. The number of Productive Animal Units seems to be increasing on the Hyde Park farms.

20. Heifers are raised to replace the dairy cows and because of cheap feed and otherwise low cost of production a few are sold as cows or heifers.

21. On the average there were about 7.4 units of dairy cows kept per farm. No more are kept because of the limited pasture, and also because the farm family usually does all the milking and the size of the herds maries as the number in the farm family. The larger families milk the they might with as large fame farmers are not milking as many cows as 22. Some range las as they have.

22. Some range cattle are kept because of the availability of some 
range land for grazing purposes on the Cache National Forest Reserve and because the milk cows cannot use the ranges to advantage.

23. Colts are raised both for work and for sale. Relatively cheap feed makes it possible to raise colts to sell.

24. On the average there is one work horse to 14 or 15 acres of crops. The better paying farms on the average have one work horse to each 15 to 19 acres of crops. This is not an especially efficient use of work horses but is undoubtedly due in part to the brood mares, the rather intensive crops grown, and the lack of usable machinery for many of the operations on the sugar-beet crop.

25. A cow pony is kept to use in driving the cows to and from pasture.

26. On all farms a total of 46 sheep including lambs are kept as scavengers. This is less than an average of 1 sheep per farm.

27. Hogs are raised for home use mainly. One reason why more are not raised is because all the farm homes and buildings are in town and a herd of hogs would be very undesirable under these conditions.

28. Hens are kept mainly to supply the farm homes with eggs and meat. More poultry in town where homes are close together would be a nuisance.

29. Hogs and hens are fed largely on table scraps, grain screenings, skim milk, and other waste-feeds. Bran and shorts are sometimes fed to hogs for a short period before butchering. These conditions tend to make cheap meat and eggs for family use.

30. There are three features of special significance in this area.

(a) Most of the land is irrigated and most of the farmers raise sugar-beets on a part of this irrigated land and milk a few cows. Water for the extension of irrigation is limited. Suitable pasture for milk cows is limited. The sugar-beet area and the number of cows milked vary directly with the number of persons in the farm family.

(b) Dry-farming is practised as a means of extending or increasing the size of the farm business. Even the dry-farm land has been taken up by the local farmers and is no longer available to entry.

(c) Grazing on the Cache National Forest offers some good opportunities to a few farmers, but even these advantages are absorbed by a few men and the ranges are stocked to their capacity.

31. Sugar-beets and wheat are raised instead of raising more pasture, barley, oats, and alfalfa as feed for livestock because:-

(a) Raising cash crops utilizes the available summer labor to good advantage.

(b) The sugar-beet crop especially makes labor for school children.

(c) The combination of livestock and these cash crops makes a more diversified and better balanced farm business and therefore a safer and more desirable business for the average farmer than the more specialized livestock farming.

(d) The combination is on the average more profitable than the specialization.

32. The balance of the farm business is fair. No regular system of crop rotations is practised. The cultivated crops receive about 6 tons of manure per acre per year, or 30 tons every 5 years. With the abundance of minerals in the virgin soil the fertility has been maintained and even increased in some cases. About 40 to 45 per cent of the farm receipts are from crops, 30 to 40 per cent from stock and stock products, 16 per cent from increase in inventory, and 9 per cent from miscellaneous sources 
such as outside labor. On the average there were 3.6 crop acres per productive animal unit. This ratio furnishes ample feed for stock and allows growing cash crops as well.

33. The 52 farms, in 1914 , had an average farm eapital of $\$ 13,642$; farm receipts, $\$ 2,510$; farm area, 105 acres; crop acres, 54 ; acres sugarbeets, 8.5 ; productive animal units, 14.8 ; milk cows, 7.5 ; work horses, 4 ; and man labor equivalent, 1.6. One of the main reasons for the few acres is found in the small farms originally taken up by squatters in 1859. Another reason is the difficulty of overcoming the obstacles to increasing the number of acres.

34. The modern farm machinery is in general use on these farms. The average value of machinery per farm is about $\$ 420$, or $\$ 5$ to $\$ 9$ per crop acre. The larger farms have more farm machinery, but the machinery cost is less per acre than on the smaller farms. It is likely that when a sugar-beet thinner and a sugar-beet topper are perfected that the acreage of these crops may be greatly increased.

35. The type of farming followed and the size of the farm business largely determine the kind and size of farm buildings required. At Hyde Park the buildings are fairly well adapted to the needs. It has happened at Hyde Park that because of insufficient storage space, grain and potatoes have of necessity been sold in the fall at harvest time, when if storage space had been available they would have been held until winter or spring.

36. The average value of dwelling house in 1914 was $\$ 1335$. The larger farms have better dwellings and better barns than the smaller farms and yet the shelter cost per animal unit is less on the larger farms than on the smaller farms.

37. Climate is the most important single factor in determining the type of farming in all parts of Utah. It determines whether irrigation is necessary, whether dry-farming will be successful, and that the desert shall remain a desert.

38. There are 151 days in the crop-growing season at Hyde Park; 16 inches is the mean annual precipitation; 7 inches fall annually between April 1 and September 30 ; the mean annual temperature is $47.6^{\circ} \mathrm{F}$. with a mean difference between night and day of $21.9 \circ \mathrm{F}$; ; the mean humidity during the day is about 50 per cent; and the annual rate of evaporation from a free-water surface is about 45 to 55 inches.

39. Topography is an important factor in determining the type of farming in Utah in general, and on individual farms. It is estimated that 40 per cent of the area of Utah will never be cultivated on account of the mountains. These mountains furnish grazing for livestock, and in Hyde Park and many other areas affect greatly the type of farming.

40. The Cache County farm solls are in the Bonneville beds and vary from gravel, small gravel, and light sand thru all grades to the heaviest and most tenacious clays. The varying soil types make it possible to diversify the farm business at Hyde Park even more than would a single soil type of good quality.

41. The control of grazing on the National Forests by government officials has (1) eliminated to a certain extent free competition in the use of grazing lands, (2) established a privileged class of farmers, and (3) largely determined the type of farming on many farms adjacent to the National Forests.

42. The carrying capacity of the Cache National Forest is estimated at 17 acres per animal unit, and it is at present stocked to its carryinf capacity. The average grazing season on this Reserve is 5 to 8 months. The grazing on National Forests affects greatly the number of animal units kept by farmers. The better the grazing facilities the greater the number of animal units kept.

43. Persons are better able to do that type of farming with which thet 
are familiar. The origin and training of the farm population are therefore important in studying types of farming. Most of the parents of the native-born white persons of foreign parentage at Hyde Park and also most of the foreign-born whites came from Great Britain and the couniries of northwestern Europe. The type of farming at Hyde Park is similar in many respects to that of these foreign countries.

44. Hyde Park farms are family-sized farms. One manager is all that is required on any of them and he does most of the farm work.

45. The average number of persons in the farm families included in this area was 7.4 , but only 6 of these persons made their home on the farm. The Hyde Park farm families are larger than the average Cache County farm family. The average farm family in Cache County is larger than the average for the State and the average for the State is greater than for the United States.

46. The size of farm family has a definite relationship to the type of farming practised as is suggested by the fact that on those farms with large families more acres of sugar-beets are raised and more milk cows are kept than on the farms with medium or small farm families. The total crop acres are also greater on the farms with large families.

47. The family income is greater on the farms with large families than on the farms with medium-sized or small families.

48. These facts indicate that the entire farm family is the basic unit around which the farm business is organized.

49. There is great variation in the value of the farm home.

50 . There is, however, no correlation between the value of the farm fome and labor income or farm income.

51. Not only family labor but also hired labor affects type of farming. The possibility of hiring school children for beets affects greatly the acreage grown at Hyde Park.

52. At Hyde Park the total man labor equivalent for the average farm was 1.6. This is equivalent to 1 man, the operator, twelve months or 1 year, and 7 months, and 6 days of additional man labor. A large part of the additional labor was furnished by the farm family and the remainder hired. A considerable part of that hired was for beet work and hay and grain harvest.

53. Sugar-beets and potatoes conflict in labor time. This is one reason why potatoes are not grown more extensively here.

54. The crop acres per man at Hyde Park $(33: 1)$ is comparable with that of the acres of improved land per person ten years old and over gainfully engaged in agriculture in Utah, $1909(37.4: 1)$. At Hyde Park, however, persons 10 years old were not considered men nor was pasture counted as crop acres.

55. Utah is not advantageously situated with respect to world markets, and prices of exported products are therefore comparatively low and prices of imported products are relatively high.

56. Where the market cannot be adapted to the type of farming otherwise best for an area, the type of farming must be adapted to the market.

57. The development of dairying followed the establishment of the condensed milk factories, creameries, and cheese factories. The growing of sugar-beets followed the erection of the sugar factories. The establishment of packing plants at Salt Lake and Ogden have stimulated pork production. As a result of higher livestock prices, less free range, and better livestock, more care is being given livestock on the farms. Because land is being used for cultivated crops and also because more hay is used for livestock feed there is less hay being exported than formerly.

58. The fact that Hyde Park is $1 \frac{1 / 2}{\text { miles east of the branch line sta- }}$ tion of the Oregon Short Line Railroad instead of nearer a main line station is a handicap in shipping to distant markets. 
59. The Utah and Idaho Central, Electric Railway, runs thru the town limits and has facilitated greatly local shipments to Preston, Idaho; Logan, Brigham, Ogden, Salt Lake, and Provo, Utah; and intermediate points.

60. The State Highway passes thru the Hyde Park township. This facilitates milk hauling and the local transportation of other farm products.

61. There were no tenant farms at Hyde Park, but 23 of the 52 farmers investigated, rented additional land.

62. Share tenancy is more common than cash tenancy in Cache County as a whole, but at Hyde Park 18 out of the 23 farmers who rented additional land, paid cash rent for it. This fact indicates that the Hyde Park farmers on the average are more prosperous than the average Cache County farmer and also that the type of farming does not lend itself so readily to share renting.

63. Pasture land rented for from $\$ 2$ to $\$ 3$ per acre and cultivated crop land for from $\$ i$ to $\$ 21$ per acre. The latter figure was paid for sugarbeet land. The average cash rent per acre*was \$9.13. The dry-farm wheat crop was divided, four-tenths to landlord and six-tenths to tenant. Hay and oats on irrigated land was rented for one-half share. On one patch of irrigated wheat the tenant got a little more than one-half, and on one patch of irrigated alfalfa the tenant received five-ninths of the crop.

64. The land is rented by these farmers to increase the size of the farm business and no doubt here, as elsewhere, renting is an intermediate step in the process of becoming owners of the land rented.

65 . The small percentage of tenancy here is due to a number of circumstances and conditions. The main reasons are as follows:

(1) The country is new and it has been easy to become a farm owner without tenancy, by (a) homesteading, or (b) purchasing.

(2) The farms are comparatively small, and therefore the total capitad necessary to purchase a farm is not so great as to be prohibitive to the moderately well-to-do.

(3) The type of farming followed is one which is conducive to ownership, is not attractive to tenants, and is not well adapted to tenant farming.

(4) The great increase in the value of the land has been a propelling influence toward land ownership. Tenancy in Utah, however, is gradually increasing.

66. Up to July 1,1918 , there had been only $8,572,842$ acres, or 16.3 per cent, of all land in Utah entered for settlement. Of this area $3,397,699$ acres were reported by the Thirteenth Census as land in farms.

67. The amendments to the Desert Land Laws and the passage of the Stock-raising Homesteads Acts have made it practicable to settle a considerable area of the remaining land of the State. These laws have theretore affected greatly the types of farming in the State.

68. Land values are largely determined by type of farming. The agricultural value of a piece of land is the capitalized agricultural income of that land with all future increases in its value discounted.to-date; and the income of the land is obviously a result of the type of farming practised.

69. The individual farmer, on land of a given value, must, however, follow a type of farming on that land that is profitable or else he will
fail.

70. Land values at Hyde Park are higher than the average state value.

71. As population increases or the relative prices of farm products rise, the land is more thoroly and intensively utilized and land values 
become greater. As interest rates become less or the value of the dollar decreases land rises in value.

72. About two-thirds of the crop land at Hyde Park is irrigated and tie other one-third is dry-farm land. An extension of agriculture is limited by water and mountains or by climate and topography.

73. At Hyde Park, as is common in Utah, the farmers own and operate the canal systems furnishing irrigation water. Water-rights in canals were obtained in payment for services in constructing the canals or were bought from the original owners. The amount of water that each farmer gets each year is often very variable and uncertain but is usually sufficient to mature his crops. The annual cost per share of stock or per acre of land irrigated was about $50 \mathrm{c}$ in 1909.

74. A good irrigating stream for the average man under average conditions is from 2 to 5 second-feet.

75. Three to 5 acre-inches is enough for a good irrigation. Two and one-half acre-feet is the maximum needed in Utah in addition to the precipitation to produce a crop if it is applied at the proper season. May 1 to August 31 .

76. One second-foot will irrigate 70 to 160 acres in the four months of the irrigation season.

77. The water-master has control over the distribution of water among the farmors and is therefore a factor in determining the type of farming.

78. The crops grown at Hyde Park do not as a rule require irrigation water at the same time and are therefore not competing crops in this respect. The nearest to competition is between potatoes and sugar-beets.

79. Lack of knowledge of the water requirements of plants, the duty of irrigation water, and the proper time to irrigate each crop may affect ype of furming by showing one crop more profitable than another. Proner irrigation mav prove the opposite crop to be more profitable. Much depends upon the knowledge of the irrigation farmer. the amount of water in the streams, and the division of the water by the water-master.

80. The tvne of farming followed depends to some extent upon the 'armers' ahility to get canital or money. Men at Hyde Park and elsewhere in Utah are not going into the livestock business as early as they would like because of insufficient funds, and yet these farms are not as heavily mortgaged as the average farm in Cache County, nor the average of the State of Utah, nor the average of the United States.

81. With the facilities at hand some of the Hyde Park farmers might, with safety, extend their farming operations by obtaining additional capital by mortgaging their farms. When the interest rate is $5 \frac{1}{2}$ per cent this practice would undoubtedly increase the average labor income of thesp firmers.

82. The average estimated total cost of farm loans on personal security in Utah. 1914. including interest, discounts, bonuses, commissions, and other extra charges was 10.4 per cent. For farmers who have to pay this high charge for the use of capital, to borrow in order to enlarge the reneral farm business is of doubtful practicability.

83. Farm profits are largely determined by the type of farming practised. The most profitable type of farming depends upon the conditions and circumstances of the individual farmer and farm.

84. Tsing 5 ner cent as the interest rate the average labor income of the Hyde Park farmers in 1914 was $\$ 946$; using $51 / 2$ per cent it was $\$ 878$; using 8 per cent it was $\$ 537$; using 8.6 per cent it was $\$ 455$; and using 9 per cent it was $\$ 400$. When interest is figured at 6 per cent labor income and the interest on investment are about equal.

85. Labor income does not include as a receipt that part of the family living obtained from the farm nor the increase in the value of the land. When these two items are included as receipts and interest is calculated at 8 per cent, the average labor income of these farmers is about $\$ 1300$, of 
which $\$ 600$ is the opportunity value of the farmer's labor and about $\$ 700$ is pay for management which cannot be delegated and risk or responsiility taken.

86. The labor incomes of the farmers of this area are better than the average of the State and perhaps some better than the average of the United states. The business is about the same each year, and tho there are always a few who make very little, if anything, the profits of the majority are normal.

87. The variations in labor income from year to year on an individual farm result from the various causes that affect farm profits on different larms, because each year, in a measure, presents an entirely new set or combination of conditions which the farmer has to meet, and over many of these he has no control whatever.

88 . The landlords who rented out their land have received on the average between 6 and 7 per cent net returns on their investment. With land increasing in value about $\$ 2.50$ per acre annually, owning Hyde Park farm land has been profitable.

89. Even if interest rates were considerably higher than 8 per cent, men would buy farm land in preference to loaning their money on farm anortgages because of this increase in land value and the rent they are able to get from its use in farming.

90 . While the average labor income of the farmers of Utah in 1910 was not juite as high as that for the average of the United States, this was due to a higher rate of interest being eharged in Utah and is offset by the increase in land values.

\section{BEAVER, BEAVER COUNTY, UTAH}

91. Beaver is situated about 300 miles south of Hyde Park.

92. The elevation at Beaver is 6,000 feet above mean sea level or 1,500 feet higher than Hyde Park.

93. Dry-farming was not practised at Beaver due to lack of sufficient precipitation during the growing season and to soil conditions.

94. Alfalfa was the principal crop grown. Over 75 per cent of the total area in crops was in alfalfa and other hay. The hay is grown largely for feed for livestock.

95. Livestock and stock products are the principal sources of income from these farms. Some hay, grain, potatoes, and fruit are sold to local markets.

96. The average expense for all labor other than that of the farm operator on the ten better-paying farms was about $\$ 696$.

97. The better paying farms had a larger business and their livestock was more productive in proportion to feed fed than the average farm.

98. Man and horse labor were both more efficient on the better-paying farms than on the average farm.

99. The farm business at Beaver is fairly diversified.

100. Cattle, sheep, dairying, and raising feed, in addition to raising 3 surplus of hay, grain, and potatoes as cash crops, make a fairly well balanced business.

101. During the winter months, however, farmers' sons spend too much time in town playing pool, ete., instead of on the farms at productive farm
labor.

102. The type of farming at Beaver is more extensive, or not so intensive, as that at Hyde Park.

103. The value of farm machinery per farm is greater at Beaver than at Hyde Park due to the kind of farming and the larger areas farmed by machinery.

104. The value of farm buildings is less at Beaver than at Hyde Park due in part to warmer climate, more recent settlement, and fewer dairy cows. 
105. The annual precipitation is about 13 inches at Beaver. All crops were irrigated in 1914.

106. The soils, as at Hyde Park, are of all grades from coarse gravels to heavy clays depending upon nearness to the valley bottom and distance from the mouth of the canyon. This area is also in the Great Interior Soil Province.

107. As at Hyde Park, there is also some bottom land needing drainage and some land above the canals which, if irrigated, would be very productive.

108. The Fillmore National Forest affords summer grazing for cattle and sheep and the Millard Desert is used for winter sheep range. These ranges will need to be handled more carefully in the future than in the past, or they will not even maintain their present carrying capacity.

109. The population of Beaver was 1,899 in 1910. A large proportion of those who were born in the United States came from Utah and other Western and Middle Western States to Beaver. The foreign-born population is largely from Northwestern Europe and Great Britain. They are therefore familiar with livestock and general farming methods.

110. The average number in the farm families on the farms at Beaver in 1914 was 5.4 persons. Two of these were less than 16 years old and 3.4 were over 16 years old. These farm families are not as large as at Hyde Park.

111. The average number of men employed per farm was 1.4. That is equivalent to the operators' full time and 0.4 of a year of other man labor performed either by other members of the farm family or by hired help. This is two and one-half months of man labor less than was utilized at Hyde Park.

112. In this area as at Hyde Park there is direct correlation between the size of farm family and number of cows kept for breeding and milk.

113. Man and horse labor seems to be fairly efficient. In 1914 there were on the average 46 productive animal units per man and 46 crop acres per man. There were 16 crop acres per work horse.

114. Beaver City is 32 miles from Milford, the nearest railway station, but the dirt road is in good condition most of the year.

115. Milford is 206 miles west of south from Salt Lake City on the Salt Lake-Los Angeles Railroad. Salt Lake is about 100 miles south of Hyde Park.

116. It is therefore about 300 miles east of north from Beaver to Hyde Park. In spite of this fact there are about 25 more days in the average crop-growing season at Hyde Park than at Beaver. This is due mainly to the greater altitude, less favorable exposure, and poorer air drainage at Beaver.

117. The main auto highway between Salt Lake City and Los Angeles, The Arrowhead Trail, passes thru Beaver.

118. Due to these market conditions the greater part of the farm products are marketed or fed on the farm.

119. Livestock are driven to the railroad and shipped to Los Angeles, Salt Lake, Ogden, Kansas City, Omaha, or Chicago.

120. Most of the eggs and farm-made butter are sold to general merchandise stores at Beaver and are taken by them in auto trucks to Mil. ford for shipment to Salt Lake and elsewhere. Some eggs and butter are sold in the mining camps near Beaver. Some cream is sold in Beaver and some in the camps. The few surplus potatoes are shipped via Milford.

121. The distance from the individual farms to the Beaver Postoffice varies from $1 / 8$ to 4 miles, so that none of them are a great distance from the local market.

122. There is very little tenancy in Beaver. As at Hyde Park, sor farmers rent additional land in order to enlarge their farm business. A Beaver City more land was rented for cash than for share, but the Thir. 
teenth United States Census shows more share than cash tenants for Beaver County.

123. The average value of land and buildings per acre at Beaver in 1915 was $\$ 43$. The value at Hyde Park was two and one-half times this mount. The lower price of land and the more extensive farming go together. The high value of land is a result of the greater profitableness of the more intensive type of farming. Farmers cannot afford to do extensive farming on high-priced land because the greater value of the land is determined largely by the more profitable and more intensive type of farming.

124. The facts given concerning water-tenure, water-rights, canal ownership and operation, duty of water, and irrigation practices at Hyde Park apply also to Beaver.

125. Only 7 out of 50 farmers reported that their farms were mortgaged. The interest rates paid varied from 5 to 9 per cent and averaged 7.14 per cent.

126. Using 7.14 per cent as the interest rate that farm capital should and could earn, the average labor income of 50 Beaver farmers in 1914 was \$92. Using 5 per cent, labor income was $\$ 396$. Using 9 per cent as the interest rate, labor income was minus $\$ 170$.

127. The labor income was greater in 1915 than in 1914 and greater in 1916 than in 1915. This was due largely to the increase in the prices of farm products.

128. In 1916 the average labor income of the farmers of this area was greater than the average labor income of the farmers at Hyde Park. This variation in labor income was undoubtedly due to the changes in the relative prices of farm products and the variation in the successes or failures of the various crop and stock enterprises in each area.

129. The type of farming at Beaver is more extensive than at Hyde Park largely because of the following factors:
(a) Climate
(b) Soll
(c) Markets
(d) National Forest ranges and winter ranges
(e) Competition of farm enterprises

130. Range cattle and sheep are the principal sources of income largely because of distance to market and the low cost of livestock production.

131. Alfalfa and other hay are the principal crops grown because of the necessity of providing winter feed for cattle and some sheep. Other crops grown are largely for stock feed or for the local market and are not important.

\section{MONROE, SEVIER COUNTY, UTAH}

132. Monroe is in the central part of the southwest quarter of Sevier County. It is three miles from Elsinore, the nearest railway station. Elsinore is on the Marysvale Branch of the Denver and Rio Grande, or Rio Grande Western Rallroad.

133. The population of Monroe in 1910 was 1227. Those persons of - the population who are not native born citizens, are largely from northwestern Europe, and are familiar with general agricultural practices. Here, as at Hyde Park and Beaver, most of the farm families live in town.

134. The elevation of Monroe is 5380 feet above mean sea level, or about 900 feet higher than Hyde Park.

135: In spite of the fact that Monroe is about 300 miles south of Hyde Park, the average length of the growing season is only 110 days. 
or 40 days less, and two weeks later than at Hyde Park. The average iate of the last killing frost in spring is May 28, as compared with May 10 , at Hyde Park. The mean annual temperature is 48 degrees $F$. or 9.5 degrees $F$. less than Beaver and about 0.4 degrees $F$. greater than for Hyde Park. The average annual precipitation is only 8.34 inches. mly 3.48 inches of which fall from April 1 to September 30 . On this account dry-farming is not practised. All crops are irrigated.

136. This area is in the Great Interior Basin Soil Province, and the 'soils are classified by the U. S. D. A. Bureau of Soils. The texture of the soils is similar to that of the other areas previously discussed.

137. There is here, also, some low wet meadow and pasture land due to over irrigation and seepage water.

138. The irrigation canals are owned and operated by the farmers who use the water.

139. There is a sugar factory at Austin, three miles north of Monoe. This factory makes it possible for Monree farmers to grow sugarheets. A cooperative cheese factory is situated at Monroe so that dairying is also developing here.

140 . One of the main auto roads of the State, running north and south, passes thru town. The wagon roads are in good condition the greater part of the year. The distance from the farms to market for the most important farm product varies from $1 / 2$ to 7 miles.

141. Monroe is not handicapped to such an extent as Beaver resrecting markets nor is it quite as well situated as Hyde Park. But as with Beaver, the main farm enterprises here are sheep and cattle, because of the distance to any large market and the low cost of livestock feed.

142. The special feature about this area is the raising of February in mbs for the early Los Angeles market. Los Angeles buyers are on the ground at selling time, and usually pay fair prices for these lambs.

143. Dairying and sugar-beet raising are becoming more important as the mirkets are developed. Here, as at Hyde Park, there is a direct correlation between size of farm family and acres of sugar-beets grown. and number of cows milked.

144. More than 61 per cent of the land was growing hay in 1914 , most of which was alfalfa.

145. Sugar-beets and some wheat were grown as cash crops.

146. Oats, rye, and barley were grown for feed.

147. Some potatoes and sweet corn were grown for home use and to supply the local market.

148. The Monroe farmers are "getting ahead." Their farm business is fairly profitable. The average labor income in 1914 was $\$ 516$ with interest charged at 5 per cent, $\$ 363$ with interest at 5.5 per cent, $\$ 196$ with interest at 8 per cent, $\$ 132$ with interest at 8.6 per cent, and $\$ 89$ with interest figured at 9 per cent. In 1914 , these farms were less nrofitable than those at Hyde Park and more profitable than those at Beaver. In 1915 and 1916 , however, these farms were more profitable than those at either Hyde Park or Beaver. This variation in profitableness is undoubtedly due to the variations in the relative prices of farm products, especially meat and wool, as well as to the variations in the successes and failures of the crop and stock enterprises. The high prices of lambs and wool have made the war years more profitable for the Monroe farmers.

\section{SANDY, SALT LAKE COUNTY, UTAH}

149. Sandy is about 20 miles south of Salt Lake City. Draper is south of Sandy. The farm business records treated in this area were taken in the townships of Sandy, Draper, Midvale, Jordan, and West Jordan. 
150. The elevation at Sandy is 4366 feet above mean sea level, or lower than any of the 8 areas studied.

151. In 1910, Sandy had a population of 1037 . There were many foreigners and persons with limited farm experience on the farms here.

152. The normal annual precipitation is 16 inches, 7 of which fall in the crop growing season. There are 89 days with .01 inch or more of precipitation, and the mean annual temperature is 51.4 degrees $\mathrm{F}$. There is a greater amount of precipitation during the crop growing season, more stormy days, and a higher mean annual temperature in this area than in any of the 8 areas studied. Dry-farming is successful in this area where soils and topography are suitable. There are 18 ? days in the average growing season which is 30 days more than in sny other area included in this study. The average date of the last killing frost in spring is April 19, showing that the season is not only longer but also earlier than in any area studied.

153. The soils of this area are typical of those of the Great Interior Basin Province. The soil types identified by the U. S. D. A. Bureau of Soils are: Jordan sanuy loam, Bingham gravelly loam, Jordan loam, Jordan clay and clay loam, Jordan meadows, Jordan sand, Bingham stony loam, and Salt Lake sand. At Sandy the soil is predominately a sandy loam. As in all Utah valleys, the soil is coarse near the mouth of the canyons at the base of the mountains, and heavy in the bottom of the valley. When irrigated and well drained, these soils are very fertile as shown by the crop yields. Some of the land is low and wet and crop yields are low on such fields.

154. Here as at Hyde Park and Monroe, the number of cows milked increases as the farm families increase in size.

155. There is a great variety of crop and stock enterprises on farms in this district.

156. Because of the climatic, market, soil, water, and transportation conditionz, a wide selection of enterprises is offered these farmers. Each farmer has his own set of conditions and he attempts to meet them to his best advantage. Consequently there is a great diversity of practices

157. Some farmers sell market milk to Salt Lake City, some ship milk to creameries, some ship to cheese factories, and a few make butter on the farms and sell it at retail. Some farmers raise hay for the Salt Lake City market, while others raise it to feed their own stock and even buy hay and grain in addition. The surplus poultry and eggs are sold to laborers of the smelters, to private parcel post customers in Salt Lake, or to a store at Sandy, Draper, or elsewhere.

158. The farm receipts were from grain, hay, potatoes, sugar-beets, vegetables, fruits, straw, dairy products, cattle, horses, sheep, wool, hogs. poultry, eggs, honey, outside labor, and increase in inventory. Grain was the main source of income. On the average, there were 7.8 crops grown pèr farm, and 5.8 sources of income per farm.

159. In 1914, with interest calculated at the rate of 5 per cent, the average labor income was $\$ 373$; with interest at $5 \frac{1}{2}$ per cent, labor income was $\$ 294$; with interest at 8 per cent, labor income was minus $\$ 102$; with interest at 8.6 per cent, labor income was minus $\$ 196$; and with interest at 9 per cent, labor income was minus $\$ 260$. In 1915 the labor income was greater than in 1914 or 1916 and was in that year also greater than the average labor income of the farmers of Hyde Park. However, the farms of the group changed greatly in 1916, or undoubtedly that would have been the banner year of the three. It is no doubt true, that the increase in the value of the land was sufficient to make up normal profits to the landlords who are operating these farms, Crop yields are not as good as at Hyde Park, yet the land is valued higher on the average here than at Hyde Park. This is because 
of markets, climate, and to the future uses other than agriculture to which these lands may be put.

\section{FERRON, EMERY COUNTY, UTAH}

160. Ferron is in the southwest corner of the northwest quarter of Emery County. It is on Ferron Creek east and near the base of the Wasatch range of mountains. The waters of Ferron Creek flow thru the San Rafael, Green, and Colorado Rivers, and empty into the Gulf of California.

161. The population of Ferron in 1910, was 651. Those farmers not native born were from northwestern Europe and Great Britain.

162. The elevation at Ferron is 5500 feet above mean sea level.

163. The normal annual precipitation is 9 inches, 5 of which fall in the growing season. The annual precipitation has varied from 3 to 13 inches. There are on the average only 37 stormy days out of 365 . It is necessary to irrigate all farm crops in this area. Ranges are poor beeause of low precipitation. The mean annual temperature is 46.1 degrees F. There are only 107 days in the average crop-growing season, June 2, to September 17.

164. Ferron is in the Rocky Mountain Valleys, Plateaus, and Plains Soil Province. The soil is not as good here as at Hyde Park, yet it is fairly fertlle and under favorable conditions produces good crops as shown by the crop yields.

165. While climate and soil handicap this area some, yet the greatest handicap is the marketing situation. Ferron is 45 miles from Price, the railroad town where some of the farm and range products from this district are marketed or loaded for shipment to market.

Mining camps, 40 to 60 miles from Ferron also offer an outlet for some farm products. Some apples, plums, and small bush-fruits; vegetables; and melons are marketed at Sunnyside, Hiawatha, Scofield, and other mining camps. Peddlers gather these products and butter and meats from farmers and sell them in the camps. In a few instances the peddlers are the farmers themselves. Some grain and baled hay are also sold in the camps. The principal source of income is range cattle. Stock can be driven to the railroad and shipped out to the great central markets.

166. Some cattle are grazed on the Manti National Forest, but most of them are grazed on the prairies or plateaus south, east, and west of Ferron. Because of the severe winter weather and the lack of winter grazing, these range cattle are fed on the farms in winter. Raising their feed is an important part of the farming operations in summer. Some farmers let the cattle stay out so late in the fall that severe storms often cause great losses from cold and starvation.

167. A few farmers have been successful in keeping bees. One farmer has done especially well the past few years with his bee business.

168. Sugar-beets are not grown to any extent here because there is no factory at which to market the beets.

169. Dairying is also limited because of lack of markets.

170. Not much care is given fruit trees because of the uncertainty of the market arid the weather. Two orchadists asked the writer's advice ebout taking out their trees and planting alfalfa. The narrow market is a great handicap to fruit growing.

171. Yet with all of these handicaps the lower valuation of land and smaller capital requirements make it possible for these farmers to make fair labor incomes. In 1914 using an interest rate of 5 per cent, the average labor income of the Ferron farmers was $\$ 326$; using a 5.5 per cent interest rate, it was $\$ 291$; using an 8 per cent interest rate, it was $\$ 117$; using an 8.6 per cent interest rate, it was $\$ 75$; and using 9 per cent 
as the interest rate it was $\$ 47$. In 1915 the average labor income was about the same as in 1914 , but in 1916 it was much greater than in either of the other two years.

\section{WELLINGTON, CARBON COUNTY, UTAH}

172. Wellington is situated west and south of the central part of Carbon County. It is about 12 miles southeast of Price on the Denver and Rio Grande Railroad.

173. In 1910 the population of Wellington was 358 . Here, as elsewhere in Utah, most of the farmers live in town and their farming lands are from 1 to 5 or 7 miles away, surrounding the town.

174. The elevation is 5540 feet above mean sea level.

175. The normal annual precipitation is only 7 inches, of which but 4 inches fall from April 1 to September 30 .

176. The climate, soil, topography, camp markets, and type of farming are very similar to those at Ferron, Emery County. Proportionately more livestock, however, are raised at Wellington than at Ferron. There are also more sheep in proportion to cattle here than at Ferron due largely to the range conditions. Alfalfa is the principal crop.

177. Records were taken here one year only, 1914, and then but 26 business statements were obtained as this is a small and limited area.

178. The average labor income of the 26 . Wellington farmers in 1914 was $\$ 165$ when interest was charged at 8 per cent, the average mortgage rate for the state. The average capital investment was $\$ 8391$ so that 8 per cent interest amounts to $\$ 671$. Undoubtedly the years 1915 and 1916 . were considerably more profitable than 1914 because of the increased livestock prices.

\section{HINCKLEY, MILLARD COUNTY, UTAH}

179. Hinckley is situated in about the center of the northeast quarter of Millard County. It is about 6 miles north and west of Oasis, which is the nearest rallway station.

180. In 1910 the population of Hinckley was 553. The majority of the persons are native-born citizens of the United States. There were a few persons from Sweden, Denmark and Great Britain. level.

181. The elevation at Hinckley is about 4541 feet above mean sea

182. The normal annual precipitation is about 8 inches, only 4 inches of which fall during the growing season. Because of this light rainfall, dry-farming is not practised. All farm crops are irrigated.

183. The Nebo National Forest to the east of Hinckley is too far away to be of any value to the farmers of this area, so the range land is very limited and what range there is is not of excellent quality.

184. This area is in the Great Interior Basin Soil Province. The soil is not as fertile as that at Hyde Park and because of poor natural drainage, is inclined to be alkaline. Clay and clay loam predominate although there is some sandy loam reported. The land in general is Aat; often it is too flat to irrigate conveniently.

185. Alfalfa is by far the most important crop grown. Other crops grown are: other hay; spring wheat, winter wheat, oats, rye, corn, and garden products.

186. Dairying is practised on some farms in a limited way, but has not yet developed to any sizable proportions nor is it likely to do so in the near future.

187. The main sources of income in 1914 were: (1) alfalfa seed. (2) alfalfa hay and other hay, and (3) cattle. The growing of alfalfa seed on most farms of this area is quite a gamble. But on a few farms a fairly good crop is obtained each year. When a crop of seed is 
obtained, the farmer makes a very good labor income, but when the crop is left for seed and the seed fails, the dry stalks are not of great value and labor income in such cases is often a minus quantity.

188. In brief, Hinckley about feeds itself, but its clothes, household goods, and other necessaries it buys outside and pays for them with alfalfa seed, hay, cattle, farm butter, surplus eggs, farm-dressed pork, a few horses, and personal services.

189. The type of farming followed is fairly well adapted to conditions and on the average is also fairly profitable. In 1914, using 5 per cent interest the average labor income of the Hinckley farmers was $\$ 613$; using 5.5 per cent interest, $\$ 565$; using 8 per cent $\$ 323$; using 8.6 per cent, $\$ 266$; and using 9 per cent, labor income was $\$ 228$. In 1915 the average labor income was less than in 1914, due largely to the fact that the alfalfa seed crop was not quite as good. In 1916 the labor income on the average was about the same as in 1914. The seed crop was not quite so good but prices were higher.

\section{PLEASANT GROVE, UTAH COUNTY, UTAH}

190. Pleasant Grove is situated just south of east of the north end of Utah Lake in Utah County.

191. The 1910 U. S. Census gave the population of Pleasant Grove as 1618. The farmers live in town while their farms are on the outskirts and in the outlying area. The people here are native born, or are from northwestern Europe or Great Britain.

192. The elevation is 4532 feet above mean sea level.

193. The normal annual precipitation is 15 inches, 6 of which fall in the growing season. Dry-farming is successfully practised here, The absolute lowest annual precipitation recorded is 9 inches and the absolute highest annual precipitation recorded is 22 inches. There are on the average, 66 days annually with .01 inch or more precipitation. The mean annual temperature is 49.7 degrees $F$. This is higher than for Hyde Park but lower than for Sandy. The warmest temperature recorded for any of the 8 areas is 105 degrees $F$. and that was recorded in the Pleasant Grove area. The average crop growing season has 145 days, or a few less than Hyde Park, and 35 to 40 less than Sandy, although situated further south than either of these areas. The average date of last killing frost in spring is May 12, or about the same as for Hyde Park, but a little earlier than Beaver, and much later than Sandy. The absolute latest date of killing frost is June 29, or about the same as at Hyde Park and Monroe.

194. This area is situated in the Great Interior Basin Soil Province. A detailed soil survey has been made of this area and the following soil types distinguished: Maricopa stony loam, Maricopa gravelly loam, Jordan clay, Fresno sand, Jordan loam, Jordan sandy loam. Salt Lake loam, and the gravel areas. These same soils are among those identified in the Sandy area. The best sugar-beet soil is the Jordan sandy loam, and the Jordan loam is the second best soil for this crop.

195. Creeks from the mountain canyons on the east of Pleasant Grove and flowing wells furnish the irrigation water for the farms. The irrigation systems are owned and operated by the farmers themselves.

196. Transportation by rail and auto roads is easy and adequate. Sugar-beets are shipped to the Lehi factory from this area.

197. The Wasatch National Forest east of town offers good grazing for stock for about 8 months of the year. More cattle than sheep were kept on this range because of adaptability and profitableness during tnese years.

198. The principal sources of income in 1916 in the order of im. portance were: sugar-beets, cattle sales, outside labor, grain, potatoes, fruit, increase in feed and supply inventory, swine sales, poultry and 
eggs, increase in livestock inventory, hay, horse sales, increase in mahinery inventory, other crop sales, increase in inventory of land and buildings, and sheep sales.

199. The average labor income of these farmers in 1916 , using 5 per cent interest was $\$ 651$; using 5.5 per cent interest, $\$ 612$; using 8 per cent interest, $\$ 418$; using 8.6 per cent interest, $\$ 370$; and using 9 per cent interest, the labor income was $\$ 340$. There is no doubt but that the years 1915 and 1914 would have shown a smaller labor income than 1916 , because the farm prices were not as high then as in 1916 .

\section{GENERAL CONCLUSIONS}

200. It has been shown in this thesis that there are a multitude of factors that affect type of farming in Utah. Some of these factors are: (1) Location of the area, (2) elevation, (3) crops, (4) crop diseases, (5) livestock, (6) crop and stock combinations, (7) pasture, (8) the returns from crops and stock, (9) diversity and balance of farm business, (10) size of farm business, (11) farm machinery, (12) buildings, (13) climate, (14) topography, (15) soil, (16) National Forests and public stock ranges, (17) population, (18) the farm family, (19) farm labor, (20) markets, (21) wagon and auto roads and railroads, (22) land-tenure, (23) land values, (24) water-tenure, (25) waterrights, (26) canal ownership and operation, (27) duty of water, (30) irrigation practice, (29) amount of irrigation water necessary, (30) amount of water to use and time of application, (31) farm credit, (32) farm mortgages, (33) other security, (34) interest rates, (35) farm profits, (36) labor incomes, (37) rents, and (38) what the farm inrnishes towards the living of the farm family.

In any specific area, however, or on any particular farm, the type of farming is determined by the combinations and inter-relations of all these natural and economic factors.

\section{ACKNOWLEDGEMENTS}

It is a pleasure to acknowledge the assistance of Dr. John D. Black, Chief of the Division of Agricultural Economics, Dr. George W. Dowrie, Professor of Economics and Dean of the School of Business, and Prof. Andrew Boss, Chief of the Division of Agronomy and Farm Management and Vice-director of the Minnesota Agricultural Experiment Stationall of the University of Minnesota-in criticising these data and their preparation, and for suggesting sources of information upon the subject investigated. Prof. George Stewart of the Agronomy Department of the Ittah Agricultural College also read the manuscript and gave some help. ful criticisms. Mr. C. G. Worsham made the drawings.

The writer appreciates the cooperation of the Utah State Leader of County Agents and the County Agents of the respective areas included in the investigation for their assistance in taking the farm business records; and he also wishes to thank the many farmers who so generously gave the information concerning their farm business.

Without financial assistance from the Utah Agricultural Experiment Station, the Utah Agricultural Extension Division, and the United States Department of Agriculture it would have been impossible for the writer to have had calculated and put in usable form all of these farm business data. 


\section{APPENDIX}

Table I.-Business Factors of Farms of Hyde Park Area, Cache County, Utah, 1914, Showing Type of Farming

\begin{tabular}{ccc}
\hline Average of 10 & Average of \\
better-paying & all 52 \\
farms & farms. \\
\hline
\end{tabular}

Diversity of Farming

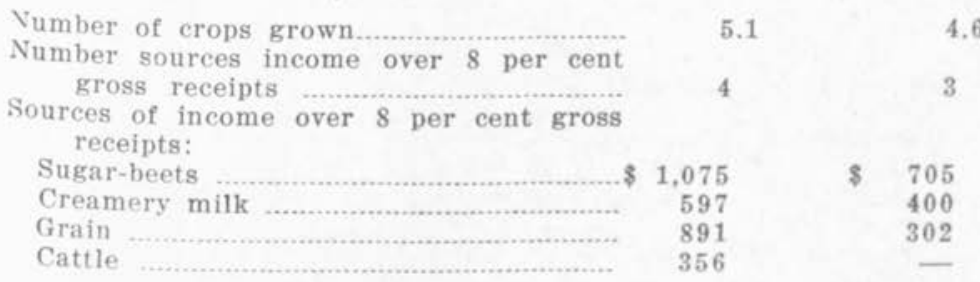

\section{Size of Farm Business}

Capital

Receipts in farm

Acres in farm

Crop acres

Acres sugar-beets

Milk Cows.

Work horses

Productive animal units (P.A.U.)

Man labor equivalent (year basis)

\section{Productivity of Crops}

Crop receipts per crop acre....

Crop yields per acre:

Potatoes

Wheat (spring and winter)

Oats

Barley (both dry-farm and irrigated)...

Alfalfa

Other hay

Sugar-beets

\section{. 6}

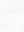

\section{Productivity of Livestock}

Net livestock receipts per $\$ 100$ feed fed....\$ 120

Net livestock receipts per P.A. U.

Cattle receipts per head...................................

Milk receipts per cow ...................................

$\begin{array}{rrr}205 & \text { bu. } & 178 \mathrm{bu} . \\ 24 & \text { bu. } & 26 \mathrm{bu} . \\ 71 & \text { bu. } & 70 \mathrm{bu} . \\ 23 \text { bu. } & 28 \mathrm{bu} . \\ 3.6 \text { tons } & 4 \mathrm{tons} \\ 2.4 \text { tons } & 2.6 \text { tons } \\ 18.6 \text { tons } & 18.6 \text { tons }\end{array}$

\section{Man Labor Efficiency}

Productive animal units per man....

Crop acres per man.

\section{Horse Labor Efficiency}

Crop acres per work horse. 
Table II.-Business Factors of Farms of the Hyde Park Area, Cache County, 1915, Showing Types of Farming

\begin{tabular}{ccc}
\hline $\begin{array}{c}\text { Average of } \\
10 \text { better- }\end{array}$ & $\begin{array}{c}\text { Average of } \\
\text { paying larms profit- } \\
\text { able farms }\end{array}$ & $\begin{array}{c}\text { Average of } \\
\text { all } 48 \\
\text { farms }\end{array}$ \\
\hline
\end{tabular}

\section{Diversity of Farming} Percentage of total farm receipts
from stock

\section{Size of Farm Business}

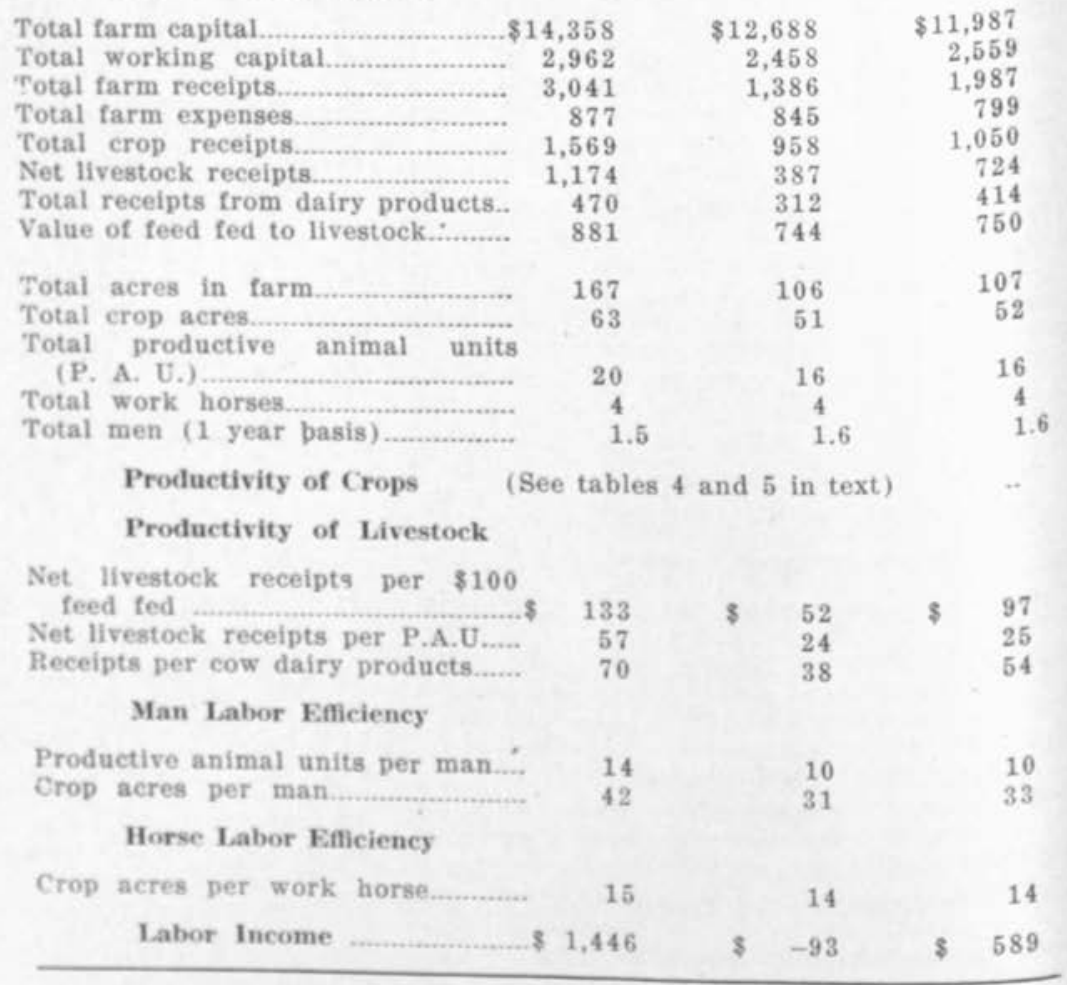


Table III.-Business Statement of 10 Better-paying Farms of the Beaver Area, Beaver County, Utah, 1914, Showing Type of Farming

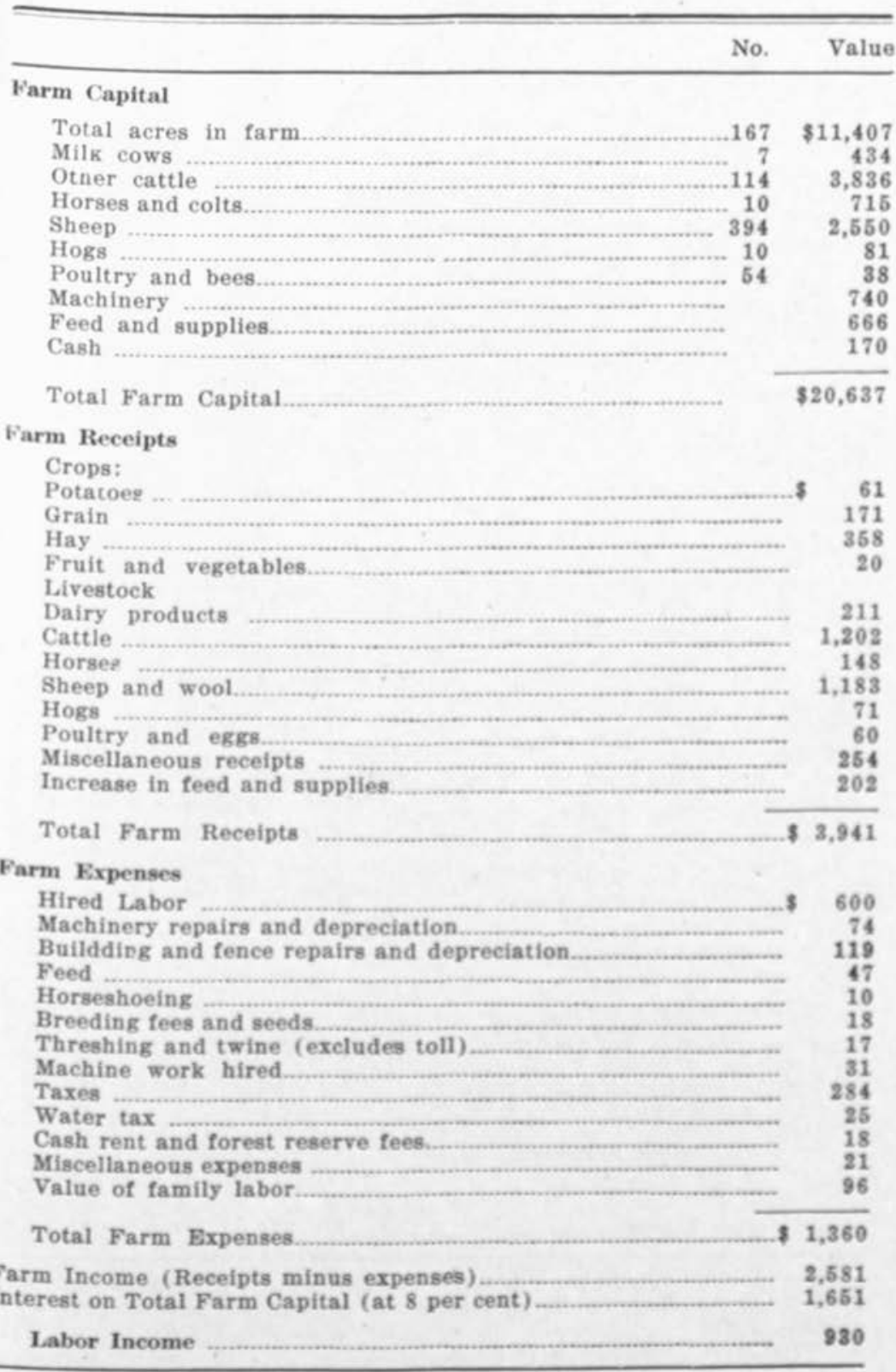


Table IV.-Business Factors of Farms of Beaver Area, Beaver County, Utah, 1914, Showing Type of Farming

\begin{tabular}{ccc}
\hline \hline $\begin{array}{c}\text { Average of } 10 \\
\text { better-paying } \\
\text { farms }\end{array}$ & $\begin{array}{c}\text { Average of } \\
\text { farms }\end{array}$ \\
\hline
\end{tabular}

\section{Diversity of Farming}

Number of sources of income....

Number of crops grown.

6.1

7.0

Number of sources income over 10 per cent gross receipts

5.4

6.4

2

Sources of income over 10 per cent gross receipts:

Cattle

$\$ 1,202$

Sheep

1,183

\$ 627

301

\section{Size of Farm Business}

Total capital $\$ 20,637$

$\$ 14,158$

179

69

51

6

Other cattle antmal mits 1.8

Productive animal units.................................. 150

\section{Productivity of Crops}

Crop receipts per crop acre. $\$ 6$

$\$ 5$

Crop yields per acre:

Potatoes

Spring wheat

Oats

Alfalfa

Other hay

$\begin{aligned} 132 & \text { bu. } \\ 23 & \text { bu. } \\ 43 & \text { bu. } \\ 2.2 & \text { tons } \\ 1.7 & \text { tons }\end{aligned}$

115 bu.

23 bu.

40 . bul.

2,4 tons 1.9 tons

\section{Prodnctivity of Livestock}

Net livestock receipts per $\$ 100$ feed fed....\$ 229

Net livestock receipts per P. A. U.(1) .............. 19

Cattle receipts per head(2) ............................ 11

Milk receipts per cow.

\section{Man Labor Efficiency}

Hiscellaneous receipts per man..................\$ 139

Productive animal units per man................. 82

Crop acres per man............................................

\section{Horse Labor Efficiency}

Crop acres per work horse.

Labor Income

(1) "A, U." represents "Animal Units", "P, A, U," represents "Pro" ductive Animal Units". Work Horses are not counted here as Productive A. nimal Units.

(2) Does not include millk cows. 
Table V.-Business Statement of Farms of Beaver Area, Beaver County, Utah, 1915, Showing Type of Farming

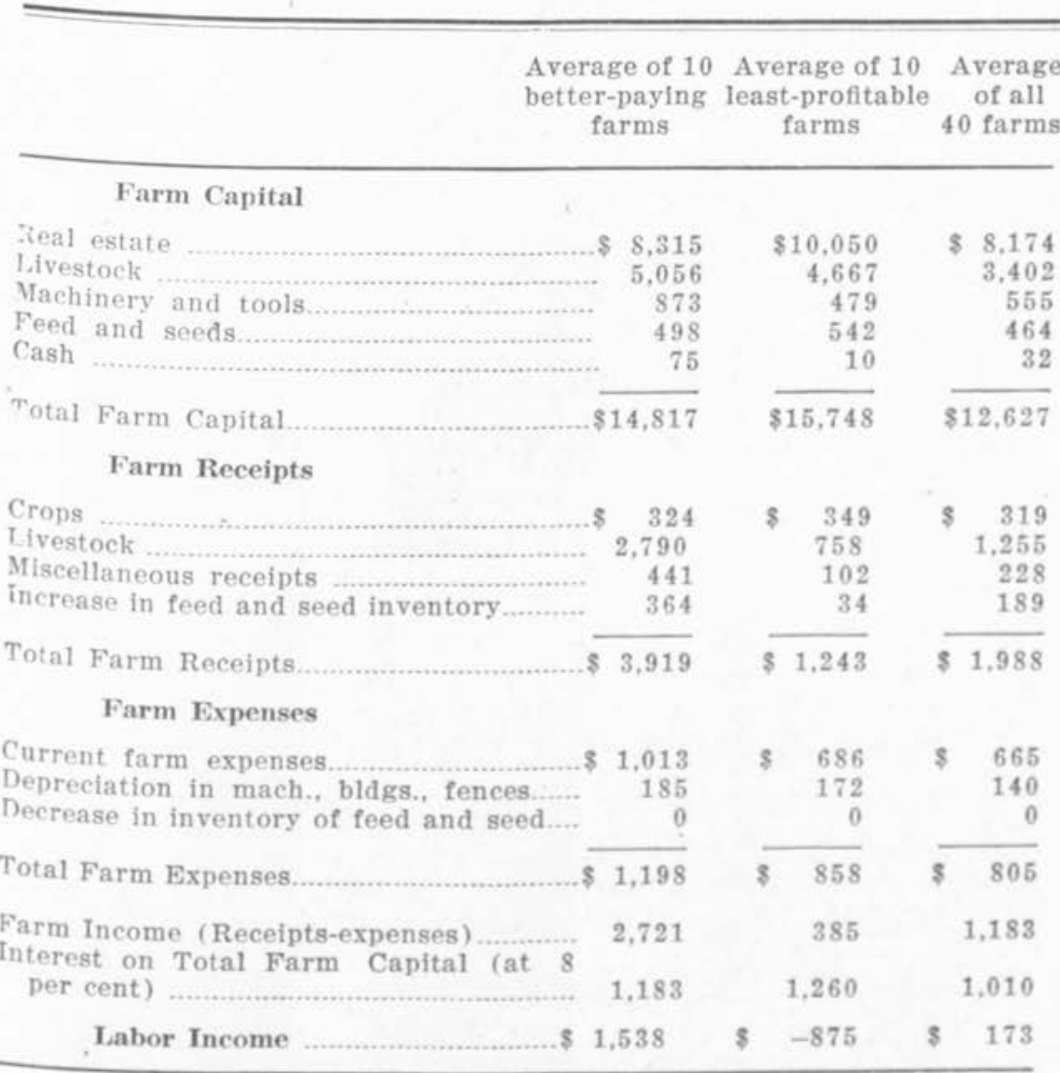


Table VI.-Business Factors of Farms of the Beaver Area, Beaver County, Utah, 1915, Showing Type of Farming

Average of 10 Average of 10 Average better-paying least-profitable

\section{Diversity of Farming}

Percentage of total farm receipts from stock

Size of Farm Business

\begin{tabular}{|c|c|c|c|c|}
\hline Fixed Farm Capital (Real Estate) ........\$ & 8,315 & $\$ 10,050$ & \multicolumn{2}{|c|}{8,174} \\
\hline Working Capital & 6,502 & 5,699 & & 4,471 \\
\hline Farm receipts & 3,919 & 1,243 & & 1,988 \\
\hline Farm expenses & 1,198 & 858 & & 805 \\
\hline Net livestock receipts......................... & 2,790 & 758 & & 1,255 \\
\hline Receipts from dairy products................... & 279 & 112 & & 209 \\
\hline Acres in farm. & 138 & 158 & & 190 \\
\hline Crop acres & 65 & 73 & & 62 \\
\hline Productive animal units (P. A. U.) ........ & 83 & 73 & & 54 \\
\hline Work horses & 4 & 5 & & 4. \\
\hline Men (1 year basis) & 2 & 1.5 & & \\
\hline Productivity of Livestock & & & & \\
\hline $\begin{array}{l}\text { Net livestock receipts per } \$ 100 \text { feed } \\
\text { fed }\end{array}$ & 265 & 72 & $\$$ & 138 \\
\hline Net livestock receipts per P. A. U....... & 34 & 10 & & 24 \\
\hline Receipts per cow dairy products........... & 47 & 17 & & 30 \\
\hline Horse Labor Efficiency & & & & \\
\hline Crop acres per work horse. & 18 & 15 & & 16 \\
\hline Labor Income ......... 8 & 1,538 & $\$-875$ & $\$$ & 173 \\
\hline
\end{tabular}


Table VII.-Business Statement of Farms of Beaver Area, Beaver County, Utah, 1916, Showing Type of Farming

Average of 10 Average of 10 Average better-paying least-profitable of all 44 farms farms farms

\section{Farm Capital}

Real estate

Land

Buildings

Livestock

Machinery.

Feed and supplies

Total Farm Capital

\section{Farm Receipts}

Crops

Potatoes

Grain

Hay

Other crops

Livestock

Dairy products

Poultry and egg sales

Cattle sales

Horse sales

Sheep sales

Swine sales

Other recelpts

Increase livestock inventory.

Increase machinery inventory.

Increase feed and supplies

Total Farm Receipts

\section{Farm Expenses}

Blacksmith and machine work

Hired labor

Machinery, bullding and fence material

Feeds and speds

Fees, rents, and taxes

Other expenses

Tivestoex purchased

Decrease in feed and supplies.

Decrease in land and bulldings.
\$ 9,261

1,720

6,332

866

698

$\$ 18,877$ s 8,660

1,955

2,385

443

679

$\$ 14,122$
\$ 7,078

1,696

3,057

504

580

$\$ 12,915$
Value of family labor.

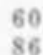

47

171

239

19

254

20

277

143

52

$2,0.32$

193

545

1,744

24

392 s

$5 \quad 51$

185

72

67

200

25

478

15

494

$\begin{array}{lr}31 & 108 \\ 31 & 39\end{array}$

215

Total Farm Expenses.

2,255

60

23

98

s 1,275

1.204

Parm income (Recelpts-expenses) _.........\$ 4,047

Interest on Total Farm Capital (at 8 per cent)

?


Table VIII.-Business Statement of 10 Better-paying Farms of the Monroe Area, Sevier County, Utah, 1914, Showing Type of Farming

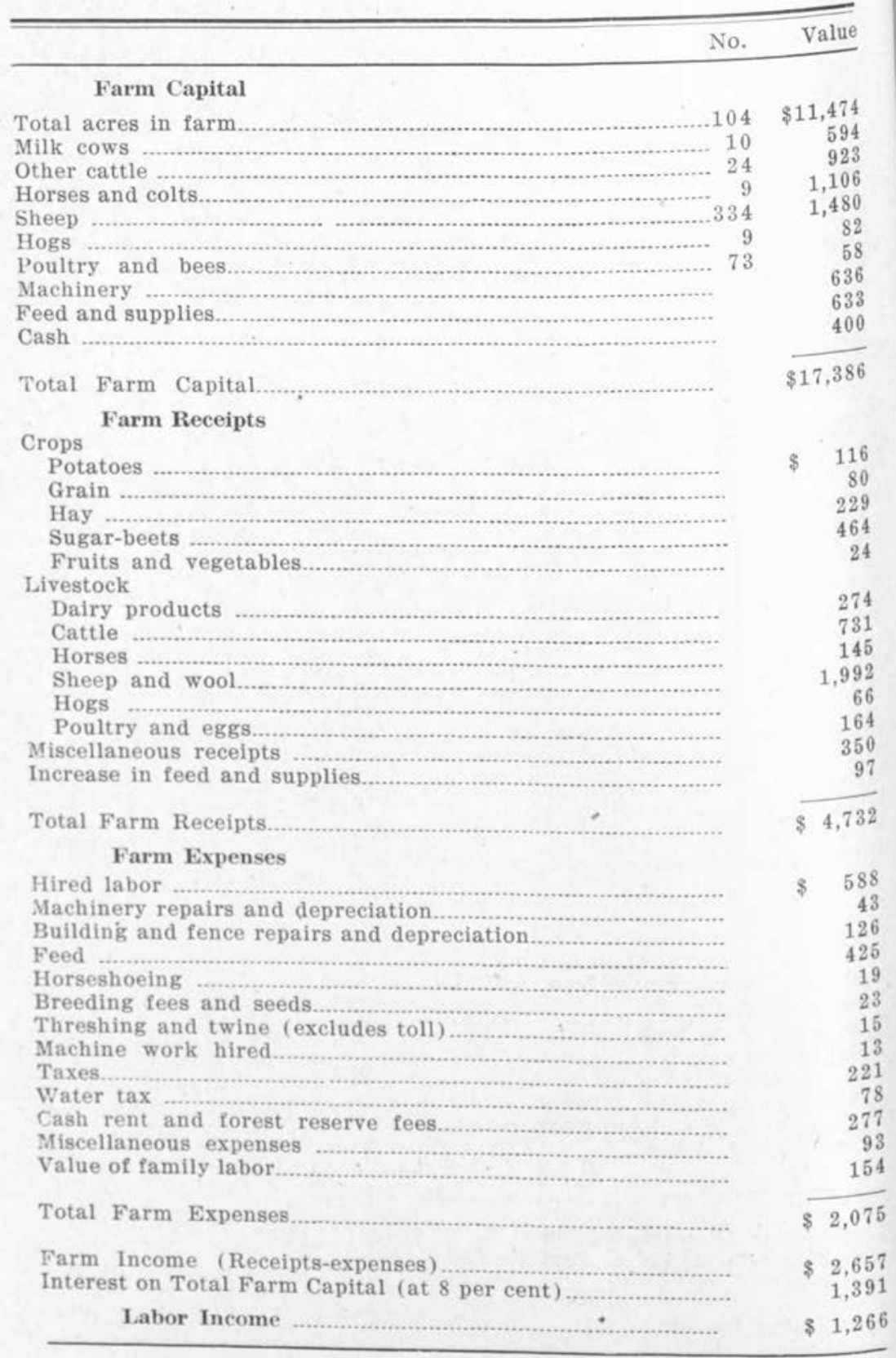


Table IX.-Business Factors of Farms of Monroe Area, Sevier County, Utah, 1914, Showing Type of Farming

\begin{tabular}{ccc}
\hline & Average of 10 & Average of \\
better-paying & all 63 \\
farms & farms \\
\hline
\end{tabular}

\section{Diversity of Farming}

Number of sources of income..............

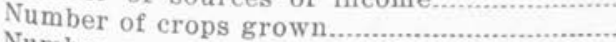

Number sources income over 10 per cent gross receipts

6.9

4.8

6.2

2 $\$ 1,992$ 731

$\$ 17,386$

Parm capital

Size of Farm Business

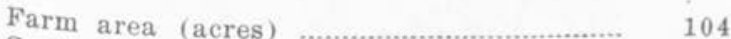

Crop acres .................................................... $\quad 74$

Acres alfalfa .................................................. $\quad 50$

Number of sheep.................................................. 334

Number of milk cows....................................... 10

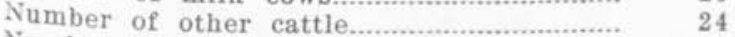

Number of animal units (1) ................................

Number of productive animal units(2)...... 68

\section{Productivity of Crops}

Crop receipts per crop acre.... $\$ 12$

Crop yields per acre:

Potatoes

Spring wheat

Oats

Alfalfa

Other hay

Sugar-beets

\section{Productivity of Livestock}

Net livestock receipts per $\$ 100$ feed fed.... $\$ 179$

Net livestock receipts per animal unit......... $\quad 46$

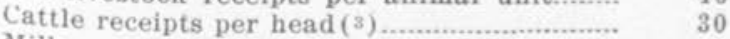

Milk receipts per cow

\section{Man Labor Efficiency}

Miscellaneous receipts per man................. $\$ 160$

Animal units per man ................................. 33

Productive animal units per man (3) ............... 31

Crop acres per man....................................

\section{Horse Labor Efficiency}

Crop acres per work, horse.

( ${ }^{2}$ Includes work horses.

(2) Does not include work horses.

(a) Does not include milk cows. 
Table X.-Business Statement of Farms of the Monroe Area, Sevier County, Utah, 1915, Showing Type of Farming

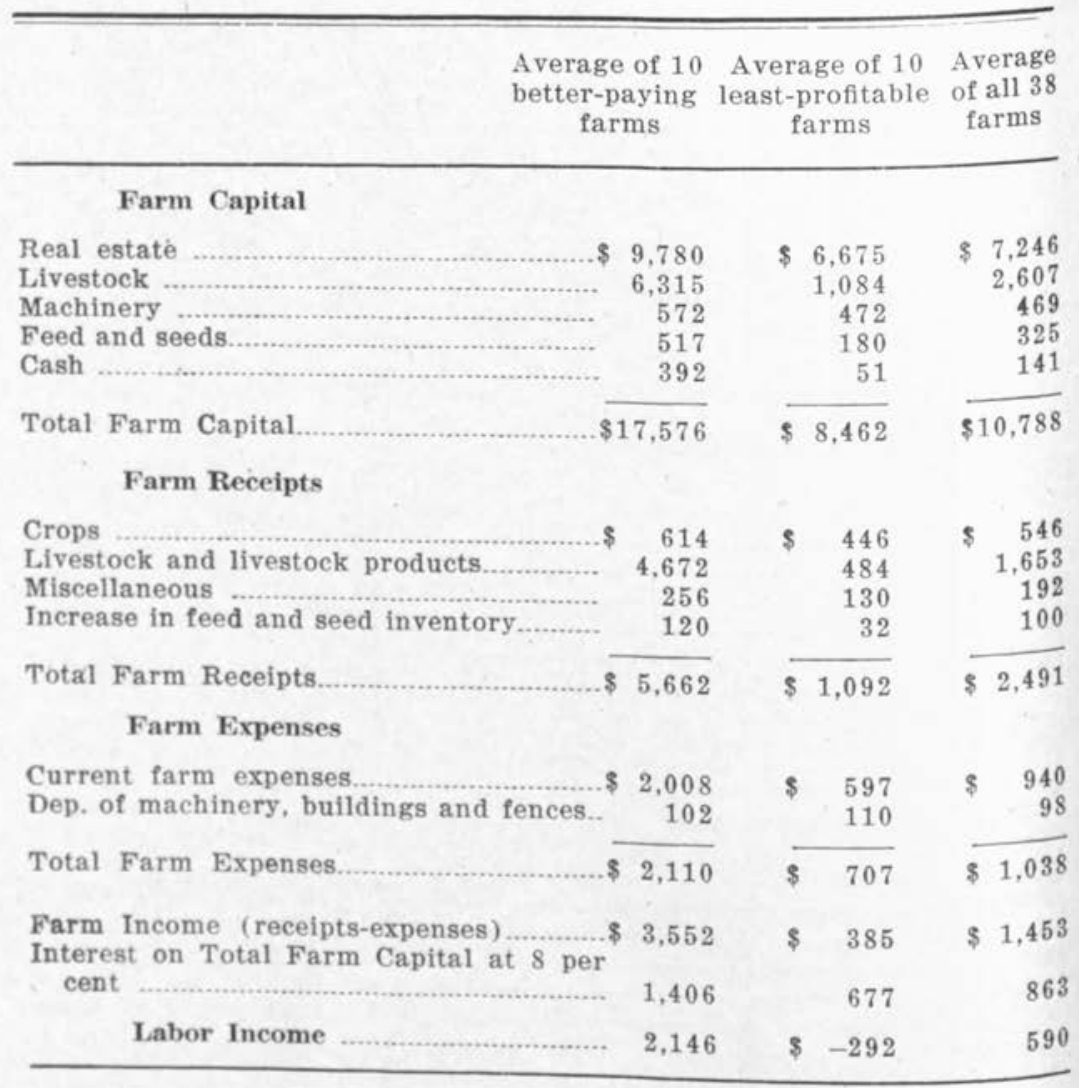


Table XI.-Business Factors of Farms of the Monroe Area, Sevier County, Utah, 1915, Showing Type of Farming

Average of 10 Average of 10 Average

better-paying least-profitable of all 38

farms farms farms

\section{Diversity of Farming}

Percentage of total farm receipts from stock ....................

Productive animal units per 100 acres crops .................................

Crop acres per productive animal unit

$\begin{array}{ccc}82 & 46 & 66 \\ 234 & 46 & 106 \\ 0.43 & 2.2 & 0.9\end{array}$

\section{Size of Farm Business}

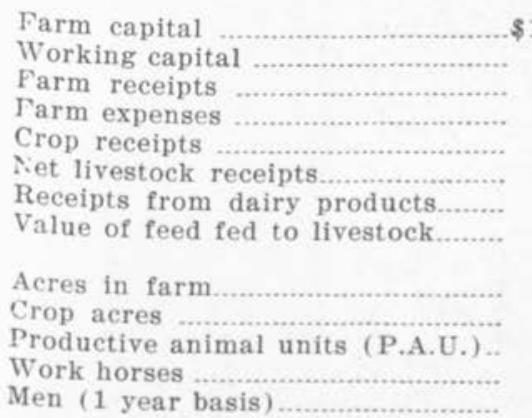

$\$ 17,576$

7,796

5,662

2,110

614

4,672

\section{5}

1,846

$\begin{array}{rrr}76 & 45 & 54 \\ 56 & 39 & 44 \\ 131 & 18 & 47 \\ 5 & 3 & 4 \\ 2.1 & 1.3 & 1.6\end{array}$

\section{Productivity of Crops}

Crop indedx ( $\left.{ }^{1}\right)$ 110

$\$ 10,788$
3,542
2,491
1,038
546
1,653
188
928
54
44
47
4
1.6

100

Crop yields per acre:

Potatoes

Oats

Barley

Alfalfa

Other hay.

Sugar-beets feed fed

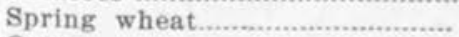

\section{Productivity of Livestock}

Net livestock receipts per $\$ 100$ 8

Net livestock receipts per P.A.U.

Man Labor Efficiency

Productive animal units per man

253

36

61

\$

79
27

\$ 178

36

149 bu.

36 bu.

52 bu.

62 bu.

3.3 tons

4.8 tons

10.2 tons

Labor Income

\$ 2,146
14

26

590

(1) Crop index shows the yields per acre compared to the average yields of the area when each crop is given its proper proportion by weighting by acreages harvested. 
Table XII.-Business Statement of Farms of the Monroe Area, Sevier County, Utah, 1916, Showing Type of Farming

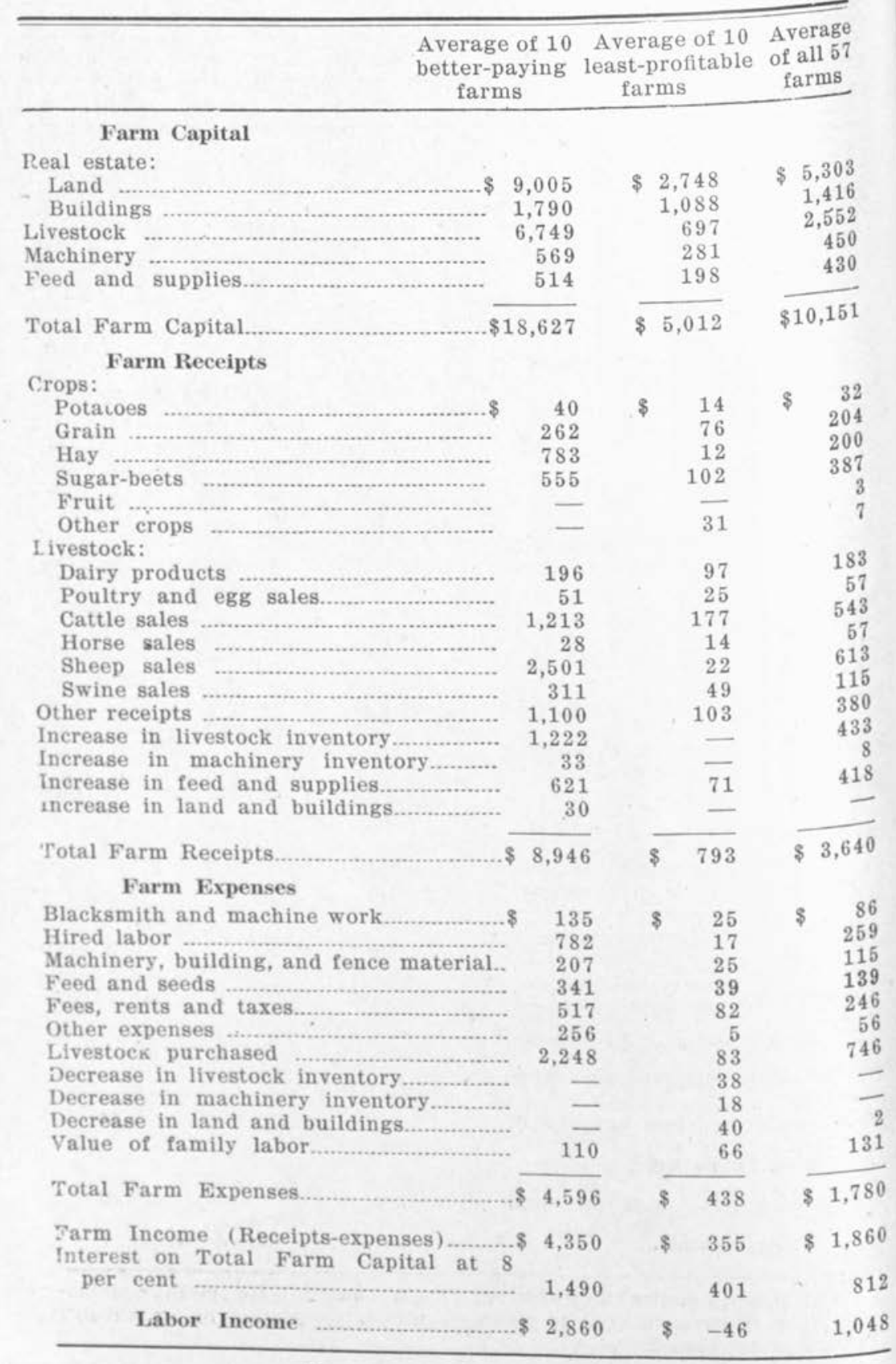


Table XIII.-Business Statement of 10 Better-paying Farms of the Sandy Area, Salt Lake County, Utah, 1914, Showing Type of Farming

\begin{tabular}{|c|c|c|}
\hline 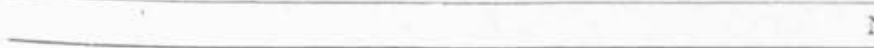 & No. & Value \\
\hline \multicolumn{3}{|l|}{ Farm Capital } \\
\hline $\begin{array}{l}\text { Total acres in farm... } \\
\text { Milk cows }\end{array}$ & 130 & $\$ 22,788$ \\
\hline $\begin{array}{l}\text { Milk cows } \\
\text { Other cattle }\end{array}$ & 9 & 691 \\
\hline Other cattle ............................................. & 13 & 524 \\
\hline Horses and colts..................... & 9 & 1,013 \\
\hline Sheep ............................... & 7 & 27 \\
\hline Hogs .............. & 12 & 116 \\
\hline Poultry ....... & 72 & 45 \\
\hline Machinery ............. & & 1,027 \\
\hline Feed and supplies...... & & 576 \\
\hline Cash ................................... & & 95 \\
\hline Total Farm Capital.. & & $\$ 26,902$ \\
\hline \multicolumn{3}{|l|}{ Crops $\quad$ Farm Receipts } \\
\hline Potatoes ......................... & $\$$ & 128 \\
\hline Grain ........... & & 704 \\
\hline Hay .............. & & 536 \\
\hline Straw ............... & & 32 \\
\hline 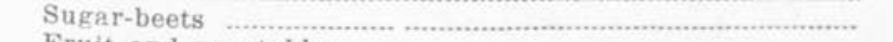 & & 295 \\
\hline Fruit and vegetables.. & & 127 \\
\hline \multicolumn{3}{|l|}{ Livestock } \\
\hline Dairy products ............. & & 1,035 \\
\hline Cattle .................................. & & 407 \\
\hline Horses ............................ & & 108 \\
\hline Sheep and wool........ & & 19 \\
\hline 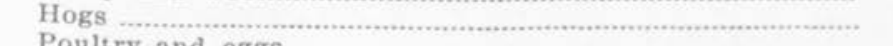 & & 211 \\
\hline Poultry and eggs.......................... & & 71 \\
\hline iscellaneous receipts ............. & & 712 \\
\hline rease in feed and supplies.... & & 282 \\
\hline Total Farm Receipts......... & $\$$ & 4,667 \\
\hline Farm Expenses & & \\
\hline $\begin{array}{l}\text { red labor } \\
\text { achinery repairs and depreciation }\end{array}$ & $\$$ & 791 \\
\hline $\begin{array}{l}\text { achinery repairs and depreciation. } \\
\text { uilding and fence repairs and depreciati }\end{array}$ & & $\begin{array}{l}44 \\
43\end{array}$ \\
\hline ed & & 110 \\
\hline orseshoeing and veterinary fees........ & & 30 \\
\hline eding fees and seeds........................ & & 76 \\
\hline $\begin{array}{l}\text { eshing and twine (excludes toll)... } \\
\text { hine work hired }\end{array}$ & & $\begin{array}{l}45 \\
48\end{array}$ \\
\hline 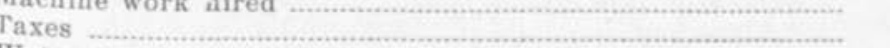 & & 123 \\
\hline 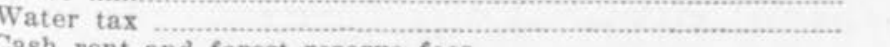 & & 71 \\
\hline rent and forest reserve fees. & & 77 \\
\hline $\begin{array}{l}\text { ellaneous expenses. } \\
\text { e of family labor. }\end{array}$ & & 97 \\
\hline or raminy lador & & 368 \\
\hline Total Farm Expenses..... & $\$$ & 1,923 \\
\hline $\begin{array}{l}\text { Tarm Income (receipts minus expenses) } \\
\text { nterest on Total Farm Capital (at } 8 \text { per cent) }\end{array}$ & & $\begin{array}{l}2,744 \\
2,152\end{array}$ \\
\hline Labor Income & & 592 \\
\hline
\end{tabular}


Table XIV.-Business Factors of Farms of Sandy Area, Salt Lake County, Utah, 1914, Showing Type of Farming

\section{Diversity of Farming}

Number of sources of income

Number of crops grown.

Number sources income over 10 per cent gross

receipts ........................................... receipts:

Sheep, hogs, poultry,

Milk and butter...

2

\section{Size of Farm Business}

Acres in farm

$\begin{array}{rr}130 & 100 \\ 104 & 55 \\ 4 & 3 \\ 2.6 & 1.7 \\ 8.8 & 4.4 \\ 6.6 & 4.1 \\ 22.4 & 15.3\end{array}$

Crop acres

Acres sugar-beets

$\$ 70$

Number of men.

Number of milk cows.

Number of work horses.

Productive animal units...

\section{Productivity of Crops}

Crop receipts per crop acre....

Crop yields per acre:

Potatoes

Wheat

Oats

Barley

Alfalfa

Other hay

Sugar-beets

$\begin{array}{rlrl}135 & \text { bu. } & 113 & \text { bu. } \\ 21 & \text { bu. } & 27 & \text { bu. } \\ 51 & \text { bu. } & 41 & \text { bu. } \\ 48 & \text { bu. } & 46 \text { bu. } \\ 3.7 & \text { tons } & 3.4 \text { tons } \\ 3.1 & \text { tons } & 2.8 \text { tons } \\ 15.4 \text { tons } & 12.1 \text { tons }\end{array}$

\section{Productivity of Livestock}

Net livestock receipts per $\$ 100$ feed fed....

Net livestock receipts per $P$. A.

$\$ \quad 148$

86

Cattle receipts per head...

Milk receipts per cow
\$ 94

48

25

53

\section{Man Labor Efficiency}

Productive animal units per man

Crop acres per man...

$$
9
$$

\section{Horse Labor Efficiency}

Crop acres per work horse.

Labor Income 
Table XV._-Business Statement of Farms of Sandy Area, Salt Lake County, Utah, 1915, Showing Type of Farming

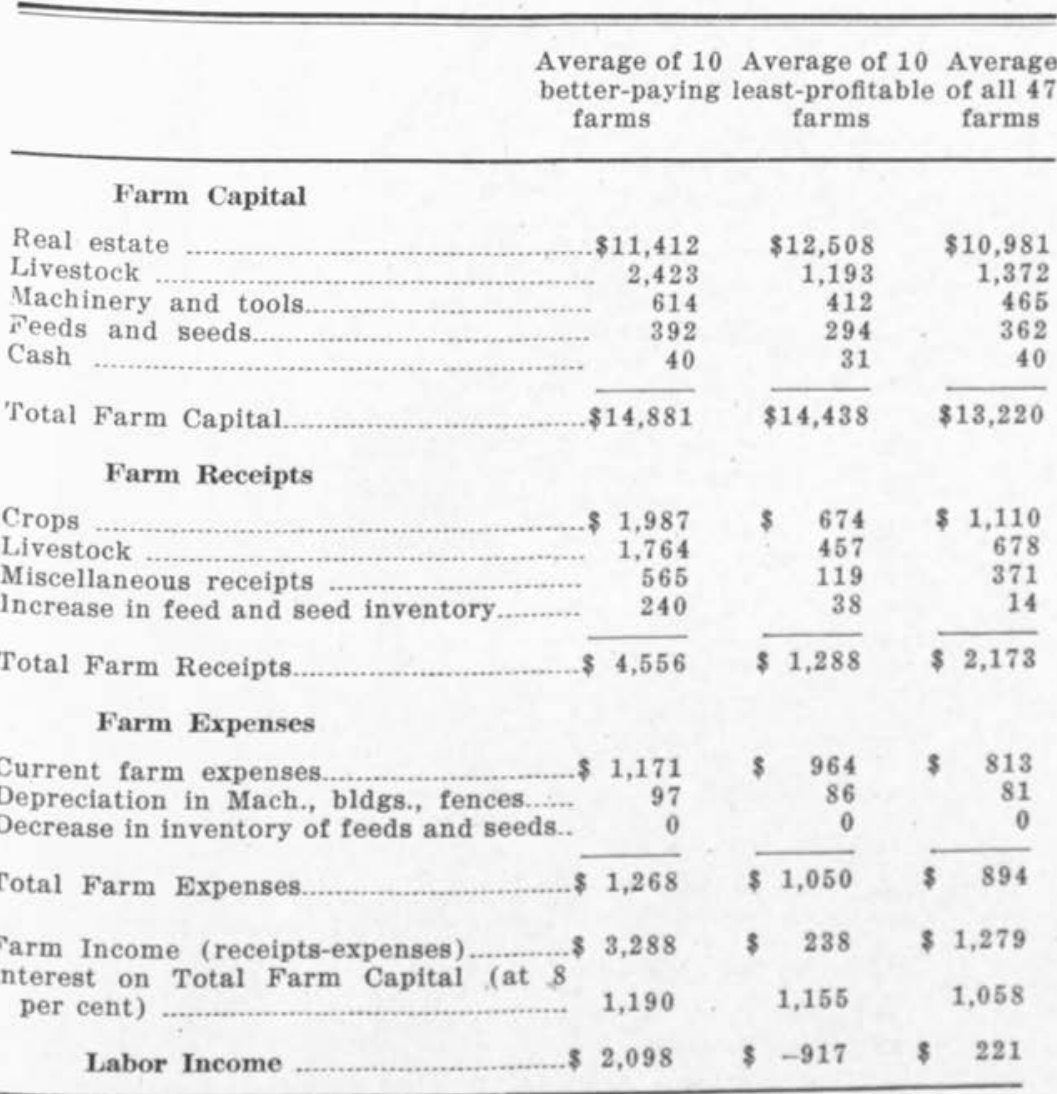


Table XVI--Business Factors of Farms of the Sandy Area, Salt Lake County, Utah, 1915, Showing Type of Farming

Average of 10 Average of 10 Average better-paying least-profitable of all 47 farms farms

farms

\section{Diversity of Business}

Productive animal units per 100 acres crops

\section{Size of Farm Business}

'Total farm capital.

Working capital

Farm receipts

Farm expenses

Crop receipts

Value of feed fed to livestock.

Net livestock receipts.

Total acres in farm

Crop acres

Productive animal units (P.A.U.) ................

Men (1 year basis)

\section{Productivity of Crops}

Crop index (percentage)

$\$ 14,881$

3,469

4,556

1,268

1,987

827

1,764

601

63

38

2.1

114

\section{Productivity of Livestock}

Net livestock receipts per $\$ 100$ feed fed

Net livestock receipts per P. A. U.

\section{Man Labor Efliciency}

I'roductive animal units per man

Crop acres per man...

\section{Horse Labor Efficiency}

f'rop acres per work horse....

$\begin{array}{rllll}213 & \$ & 60 & \$ & 92 \\ 47 & & 36\end{array}$

Labor Income

\$ 2,089 
Table XVII.-Business Statement of Farms of Sandy Area, Salt Lake County, Utah, 1916, Showing Type of Farming

Average of 10 Average of 10 Average

better-paying least-profitable of all 45 farms farms farms

\section{Farm Capital}

Real estate:

Land .................................................. \$ 5,047

Buildings ............................................ 1,475

Livestock .......................................... 1,202

Machinery ................................................... $\quad 342$

Feed and supplies......................................... 350

Total Farm Capital................................ \& 8,416

\begin{tabular}{rr}
$\$ 8,930$ & $\$ 4,985$ \\
1,266 & 1,147 \\
789 & 828 \\
352 & 264 \\
304 & 228 \\
\hline$\$ 11,641$ & $\$ 7,452$
\end{tabular}

\section{Farm Receipts}

Crops

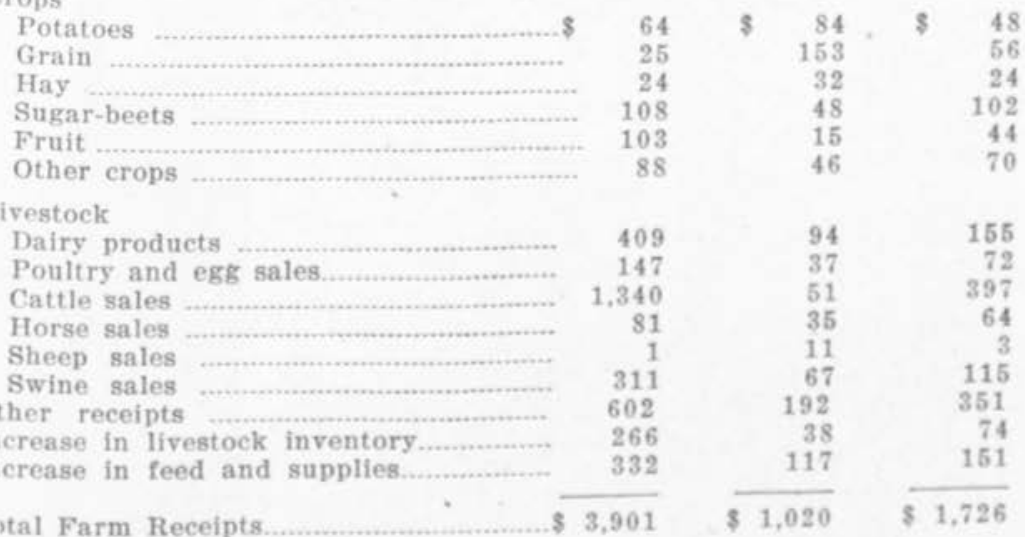

\section{Farm Expenses}

Blacksmith and machine work ............... \$ 45

Hired lahor 152

Mach., bldg., and fence material............... 20

Feed and seeds 111

Fees, rents, and taxes............................ 146

Other expenses

Livestock purchased ............................ 1,367

Decrease in machinery inventory .............. 19

Decrease in land and bulldings. 29

Value of family labor.............................. 105

Total Farm Expenses............................. $\$$

Farm income (Receipts-expenses) _............\$ 1,885

Interest on Total Farm Capital (at 8

\begin{tabular}{rrrr}
$\$$ & 51 & $\$$ & 38 \\
196 & & 98 \\
& 15 & & 21 \\
& 19 & & 58 \\
& 172 & & 133 \\
& 14 & & 15 \\
& 113 & & 377 \\
& 15 & & 5 \\
& 25 & & 23 \\
& 99 & & 71 \\
\hline$\$$ & 719 & $\$$ & 839 \\
$\$$ & 301 & $\$$ & 887 \\
& 931 & & 596 \\
$\$$ & -630 & $\$$ & 291 \\
\hline
\end{tabular}

Labor Income

$-\$ 1,212$ 
Table XVIII.-Business Statement of 10 Better-paying Farms of the Ferron Area, Emery County, Utah, 1914, Showing Type of Farming

$\overline{\text { No. Value }}$

\section{Farm Capital}

Total acres in farm $\ldots$

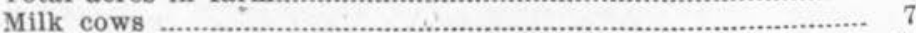

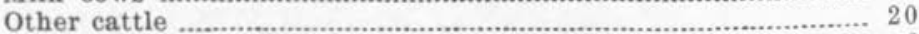

Horses and colts

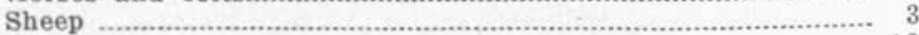

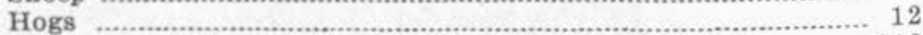

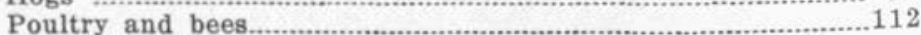

Machinery

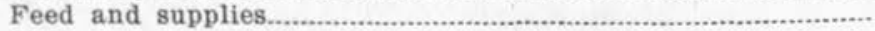

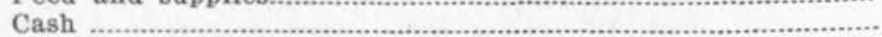

Total Farm Capital.

\section{Farm receipts}

\section{Crops}

Potatoes

Grain

Hay

Seeds

Fruit and vegetables.

Livestock

Dairy products

Cattle

Horses

Sheep and wool

Hogs

Poultry and eggs.

Miscellaneous receipts

Increase in feed and supplies.

Total Farm Receipts.

\section{Farm Expenses}

Hired labor

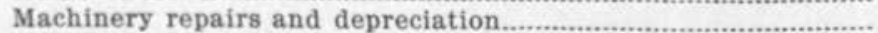

Building and fence repairs and depreciation.............................

Feed

Horseshoeing

Breeding fees and seeds

Threshing and twine (excludes toll)

Machine work hired.

Taxes

Water tax

Cash rent and forest reserve fees.

Miscellaneous expenses

Value of family labor.

Total Farm Expenses.

Farm Income (receipts minus expenses). 
Table XIX.-Business Factors of Farms of Ferron Area, Emery County, Utah, 1914, Showing Type of Farming

Average of 10
better-paying farms 39 farms

\section{Diversity of Farming}

Number of sources of income...

Number of crops grown.

Number of sources income over 10 per eent gross receipts

Sources of income over 10 per cent gross receipts:

Cattle

Other livestoek (hogs, poultry, and bees).....

\section{Size of Farm Business}

Total farm capital \& 8,094

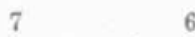

Farm area (acres)

Crop acres

Acres alfalfa and other hay

Number milk cows.

Number other cattle.

Productive animal units (P.A.U.)

\section{Productivity of Crops}

Crop receipts per crop acre... $\$$

$10 \$ \$ \quad 6$

Crop yields per acre:

Potatoes

Spring wheat

Oats

Alfalfa

Other hay

\section{Productivity of Livestock}

Net livestock receipts per $\$ 100$ feed fed..........\$ 238

Net livestock receipts per P.A.U........................ 45

Cattle receipts per head.......................................

Milk receipts per cow ......................................... 36

\section{Man Labor Efficiency}

Miscellaneous receipts per man. 8116

$\begin{array}{rlrl}86 & \text { bu. } & 73 & \text { bu. } \\ 18 & \text { bu. } & 16 & \text { bu. } \\ 39 & \text { bu. } & 32 & \text { bu. } \\ 2 & \text { tons } & 1.8 \text { tons } \\ 1.7 \text { tons } & 1.7 \text { tons }\end{array}$

Productive animal units per man.

\section{Horse Labor Efficiency}

Crop acres per work horse.

Labor Income 
Table XX.-Business Statement of Farms of Ferron Area, Emery County, Utah, 1915. Showing Type of Farming

Average of 10 Average of 10 Average better-paying least-profitable of all 48 farms

farms farms

\section{Farm Capital}

Real estate

\$ 3,581

2,111

Livestock

Machinery and tools.

Feed and seeds.

Cash

Total Farm Capital

\section{Farm Receipts}

Crops

Livestock $\$ 458$

Miscellaneous receipts

Increase in feed and seeds inventory...

Total Farm Receipts.

\section{Farm Expenses}

Current farm expenses

Depreciation in mach., buildings, fences

Decrease in inventory of feed and seeds

Total Farm Expenses. $\$ \quad 543$

Farm Income (receipts-expenses) \$ 1,426

Interest on Total Farm Capital at 8 per cent)

\section{\$ 4,587}

2,151

410

206

17

$\$ 7,371$

\$ 3,868 1,984 382 208 15

\& 6,457

$\$ \quad 269 \quad \$ \quad 321$
$4 \quad 653$

166

41

38

27

$\$ 1,181$

$\$ \quad 757$

$\begin{array}{rrr}692 & \$ & 481 \\ 65 & & 64\end{array}$

0

$\$ \quad 757$

\& 545

$\$ \quad 000 \$ 636$

590

517

\begin{tabular}{llll}
5 & $-590 \quad \$$ & 119 \\
\hline
\end{tabular}


Table XXI.-Business Factors of Farms of the Ferron Area, Emery County, Utah, 1915, Showing Type of Farming

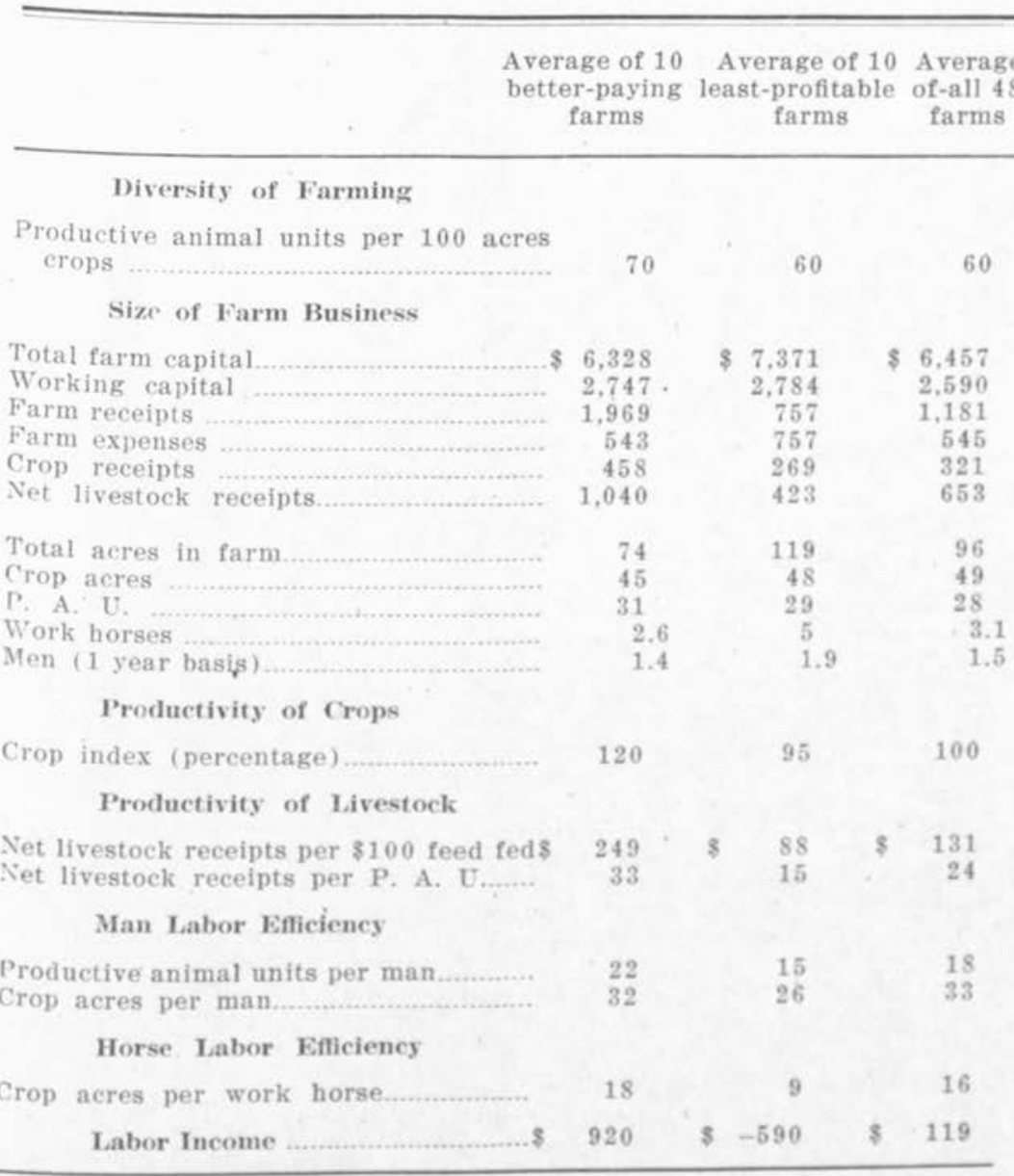


Table XXII.-Business Statement of Farms of Ferron Area, Emery County, Utah, 1916, Showing Type of Farming

\begin{tabular}{|c|c|c|c|c|c|}
\hline & $\begin{array}{l}\text { Average of } 10 \\
\text { better-paying } \\
\text { farms }\end{array}$ & \multicolumn{2}{|c|}{$\begin{array}{l}\text { Average of } 10 \\
\text { least-profitable } \\
\text { farms }\end{array}$} & \multicolumn{2}{|c|}{$\begin{array}{l}\text { Average } \\
\text { of all } 34 \\
\text { farms }\end{array}$} \\
\hline \multicolumn{6}{|l|}{ Farm Capital } \\
\hline \multicolumn{6}{|l|}{ Real estate } \\
\hline Land ........................................ & 3,339 & $\$$ & 3,660 & $\$ 2$ & 2,866 \\
\hline 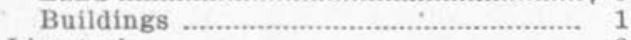 & 1,248 & & 1,226 & & 1,163 \\
\hline 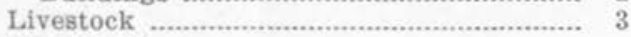 & 3,095 & & 1,958 & & 2,075 \\
\hline 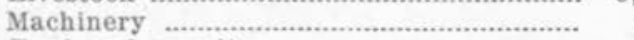 & 526 & & 318 & & 397 \\
\hline Feed and supplies.............................................. & 307 & & 229 & & 268 \\
\hline Total Farm Capital................ & 8,515 & $\$$ & 7,391 & $\$ 6$ & 6,769 \\
\hline \multirow{2}{*}{\multicolumn{6}{|c|}{$\begin{array}{l}\text { Farm Receipts } \\
\text { Crops } \\
\text { Potatoes }\end{array}$}} \\
\hline & & & & & \\
\hline Potatoes & 10 & $\$$ & 13 & $\$$ & 13 \\
\hline & 57 & & 28 & & 95 \\
\hline $\begin{array}{l}\text { Haỳ } \\
\text { Fruit }\end{array}$ & 20 & & 6 & & 11 \\
\hline Fruit & 500 & & 17 & & 166 \\
\hline \multirow{2}{*}{\multicolumn{6}{|c|}{ Livestock }} \\
\hline & & & & & \\
\hline 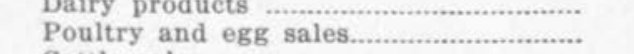 & $\begin{array}{r}81 \\
156\end{array}$ & & $\begin{array}{l}42 \\
56\end{array}$ & & $\begin{array}{l}60 \\
82\end{array}$ \\
\hline 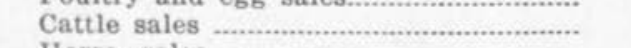 & 456 & & 106 & & 221 \\
\hline Horse sales ……................................. & 35 & & 139 & & 91 \\
\hline 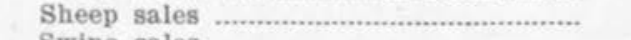 & 21 & & - & & 7 \\
\hline 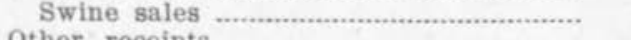 & 105 & & 66 & & 82 \\
\hline Other receipts & 445 & & 44 & & 206 \\
\hline Increase in livestock inventory & 719 & & - & & 253 \\
\hline Increase in machinery inventory ............. & 39 & & - & & 13 \\
\hline Increase in feed and supplies........................... & 154 & & 114 & & 175 \\
\hline \multirow{2}{*}{\multicolumn{6}{|c|}{$\begin{array}{l}\text { Total Farm Receipts.......... } \\
\text { Farm Expenses }\end{array}$}} \\
\hline & & & & & \\
\hline Blacksmith and machine work... & 46 & $\$$ & 38 & $\$$ & 51 \\
\hline $\begin{array}{l}\text { Hired labor ................................ } \\
\text { Mach bldg. and fence material }\end{array}$ & 60 & & 1 & & \\
\hline $\begin{array}{l}\text { Mach., bldg., and fence material................ } \\
\text { Yeed and seeds........... }\end{array}$ & 90 & & 13 & & 64 \\
\hline $\begin{array}{l}\text { Feed and seeds. } \\
\text { Fees, rents and taxes. }\end{array}$ & 40 & & 23 & & 24 \\
\hline $\begin{array}{l}\text { Fees, rents and taxes } \\
\text { Other expense }\end{array}$ & 147 & & 87 & & $\begin{array}{r}101 \\
26\end{array}$ \\
\hline & 37 & & 12 & & $\begin{array}{r}26 \\
153\end{array}$ \\
\hline 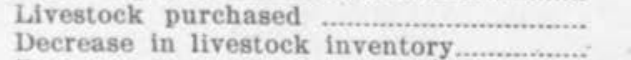 & 294 & & 26 & & $15^{3}$ \\
\hline $\begin{array}{l}\text { Decrease in livestock inventory.............. } \\
\text { Decrease in machinery inventory ............ }\end{array}$ & - & & 57 & & 三 \\
\hline & $\overline{-}$ & & 15 & & $\overline{39}$ \\
\hline 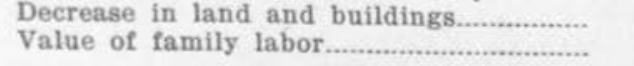 & $\begin{array}{r}56 \\
169\end{array}$ & & $\begin{array}{l}51 \\
76\end{array}$ & & $\begin{array}{r}39 \\
104\end{array}$ \\
\hline Value of ramily labor.................................... & & & 76 & & \\
\hline Total Farm Expenses.... & 939 & $\$$ & 399 & $\$$ & 590 \\
\hline \multirow{3}{*}{$\begin{array}{r}\text { Interest on Total Farm Capital (at } 8 \\
\text { per cent) } \\
\text { Labor Income }\end{array}$} & 1,963 & $\$$ & 244 & $\$$ & 954 \\
\hline & 681 & & 591 & & 542 \\
\hline & 1,282 & $\$$ & -347 & $\$$ & 412 \\
\hline
\end{tabular}


Table XXIII-Business Statement of 10 Better-paying Farms of the Hinckley Area, Millard County, Utah, 1914, Showing Type of Farming

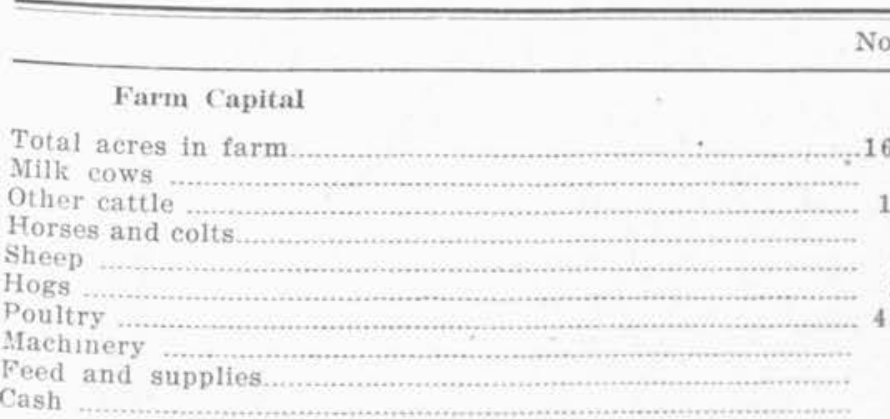

Value

Tota1-Farm Capital.

\section{Crops}

\section{Farm Receipts}

Potatoes

Grain

Hay

Fruit and vegetables.

Alfalfa seed

Livestock

Dairy products

Cattle

Horses

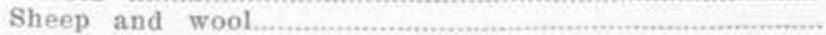

Hogs

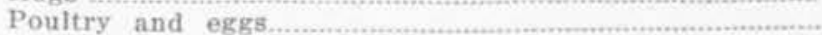

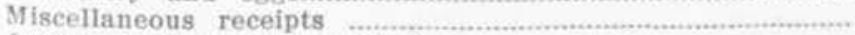

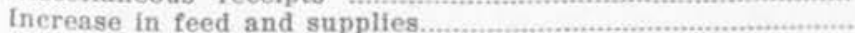

Total Farm Receipts.................................................... \$ 2,838

\section{Farm Expenses}

Hired labor

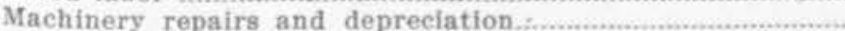

Building and fence repairs and depreciation.............................

Feed

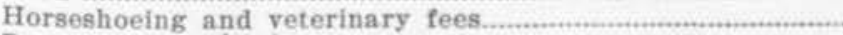

Breeding fees and seeds.

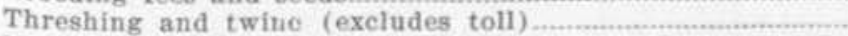

Machine work hired

Taxes

Water tax

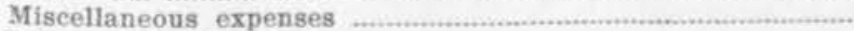

Value of family labor.

\section{Total Farm Expenses.}


Table XXIV.-Business Factors of Farms of Hinckley Area, Millard County, Utah, 1914, Showing Type of Farming

Average of 10 bet- Average of all paying farms 59 farms

\section{Diversity of Farming}

Number of sources of income....

Number of crops grown.

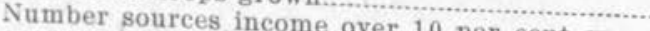
receipts .... Sources of income over 10 per cent gross
receipts:

Alfalfa seed

Hay

Cattle

.

$\$ 1,019$

531

329

$\begin{array}{ll}6.3 & 5.2 \\ 4.3 & 4 \\ 3 & 3\end{array}$

Size of Farm Business

Total farm capital.

Total acres in farm.

Crop acres

Acres alfalfa

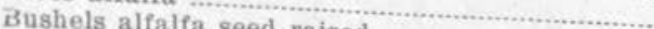

Number of milk cows kept.

Number of milk cows kept.

Number of work horses...

Productive animal units.

\section{Productivity of Crops}

Crop receipts per crop acre...

Receipts from alfalfa seed per acre.

Crop yields per acre:

Potatoes

Spring wheat

Fall wheat.

Oats

Rye

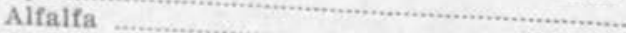

Alfalfa chaff

Productivity of Livestock

Net livestock receipts per $\$ 100$ feed fed....

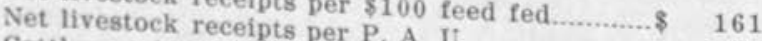

Cattle receipts per head......................... 43

Milk receipts per cow......

\section{Man Labor Efficiency}

$\begin{array}{llrl}55 & \text { bu. } & 49 & \text { bu. } \\ 10 & \text { bu. } & 6 & \text { bu. } \\ 11 & \text { bu. } & 23 & \text { bu. } \\ 20 & \text { bu. } & 16 & \text { bu. } \\ & \\ 2.2 & \text { tons } & 2.2 \text { bu. } \\ 0.7 \text { tons } & \\ & & 0.8 \text { tons }\end{array}$

Productive animal units per man

Crop acres per man....

Horse Labor Efficiency

Crop acres per work horse. 
Table XXV.-Business Statement of Farms of Hinckley Area, Millard County, Utah, 1915, Showing Type of Farming

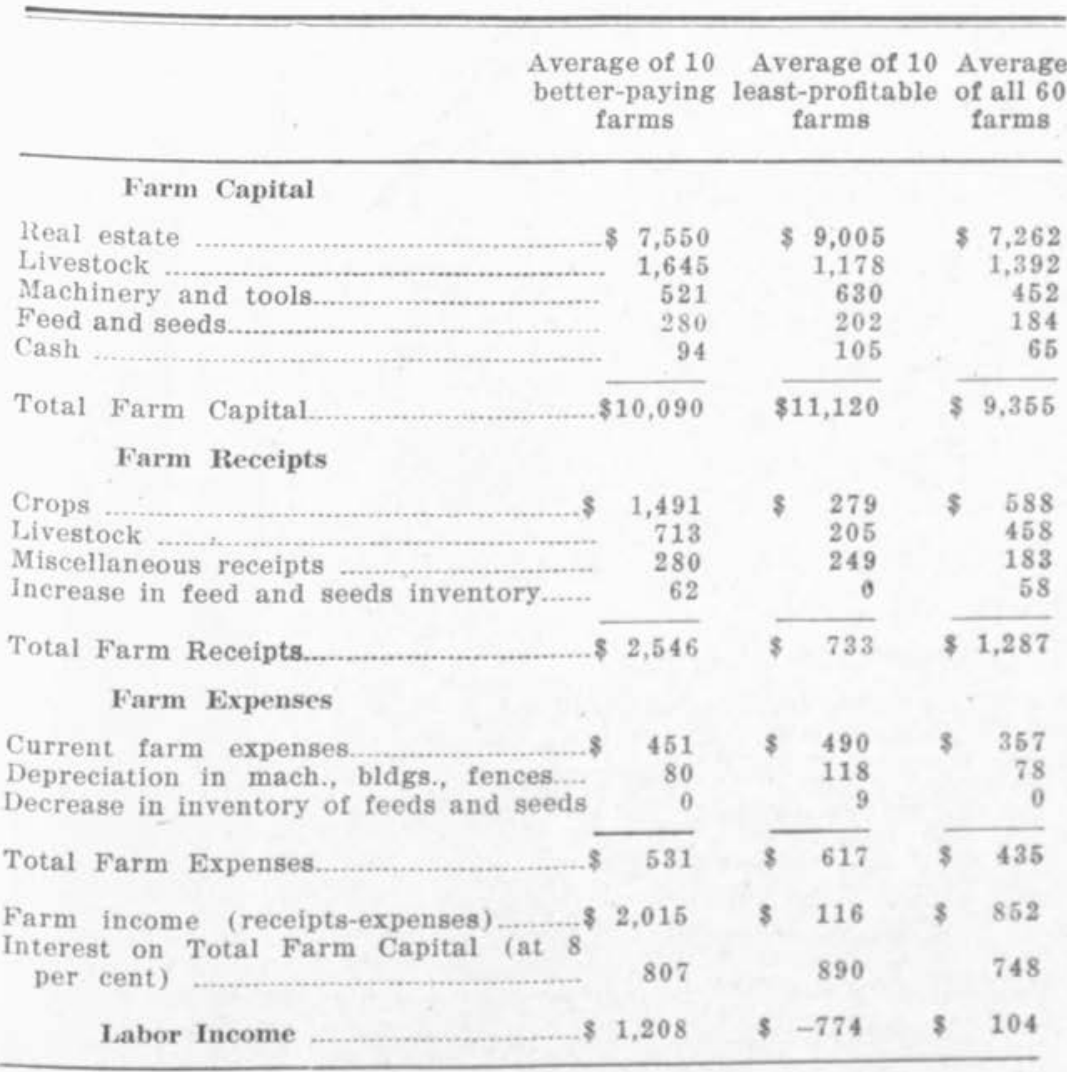


Table XXVI.-Business Factors of Farms of the Hinckley Area, Millard County, Utah, 1915, Showing Type of Farming

Average of 10 Average of 10 Average better-paying least-profitable of all 60 farms farms farms

\section{Diversity of Farming}

Productive animal units per 100 acres crops

\section{Size of Farm Business}

Total farm capital. $\$ 10,090$

Working capital 2,540

Total acres in farm 114

Crop acrees

Productive animal units (P. A. U.)

\section{Productivity of Crops}

Crop index (percentage)

$\begin{array}{rr}\$ 11,120 & \$ 9,355 \\ 2,115 & 2,092 \\ & 155 \\ 209 & 51 \\ 49 & 16 \\ 11 & \\ & 100 \\ 88 & \end{array}$

\section{Productivity of Livestock}

Net livestock receipts per $\$ 100$ feed fed..\$ 119

Net livestock receipts per P. A. U............... 31

Feed fed per livestock unit.

23

\section{Man Labor Efficiency}

Productive animal units per man............... $\quad 18$

Crop acres per man.

Horse Labor Efficiency

Crop acres per work horse.

Labor Income $\$ 1,208$ 
Table XXVII.-Business Statement of Farms of Hinckley Area, Millard County, Utah, 1916, Showing Type of Farming

\begin{tabular}{|c|c|c|c|c|c|}
\hline & $\begin{array}{l}\text { Average of } 10 \\
\text { better-paying } \\
\text { farms }\end{array}$ & \multicolumn{2}{|c|}{$\begin{array}{l}\text { Average of } 10 \\
\text { least-profitable } \\
\text { farms }\end{array}$} & \multicolumn{2}{|c|}{$\begin{array}{l}\text { Average } \\
\text { of all } 39 \\
\text { farms }\end{array}$} \\
\hline \multicolumn{6}{|l|}{ Farm Capital } \\
\hline \multicolumn{6}{|l|}{ Real estate } \\
\hline Land ........ & 5,033 & $\$$ & 6,665 & $\$$ & 5,171 \\
\hline Buildings ...... & 754 & & 1,571 & & 938 \\
\hline Livestock ............ & 1,491 & & 1,023 & & 1,246 \\
\hline 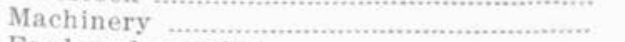 & 552 & & 383 & & 408 \\
\hline Feed and supplies... & 282 & & 184 & & 220 \\
\hline Total Farm Capital.... & 8,112 & $\$$ & 9,826 & $\$$ & 7,983 \\
\hline \multicolumn{6}{|l|}{ Farm Receipts } \\
\hline \multicolumn{6}{|l|}{ Crops } \\
\hline Potatoes & 17 & $\$$ & - & $\$$ & 2 \\
\hline Grain ........ & 242 & & 154 & & 146 \\
\hline Hay .................. & 551 & & 55 & & 222 \\
\hline 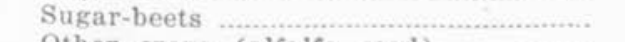 & $-\bar{n}$ & & $\longrightarrow$ & & 9 \\
\hline $\begin{array}{l}\text { Other crops (alfalfa seed) } \\
\text { Livestock }\end{array}$ & 777 & & 87 & & 307 \\
\hline \multicolumn{6}{|l|}{ Livestock } \\
\hline 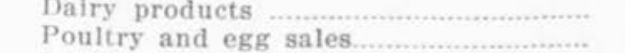 & $\begin{array}{r}124 \\
82\end{array}$ & & $\begin{array}{l}87 \\
25\end{array}$ & & $\begin{array}{r}112 \\
60\end{array}$ \\
\hline $\begin{array}{l}\text { Poultry and egg sales.... } \\
\text { Cattle sales }\end{array}$ & $\begin{array}{r}82 \\
223\end{array}$ & & $\begin{array}{r}25 \\
101\end{array}$ & & $\begin{array}{r}60 \\
167\end{array}$ \\
\hline 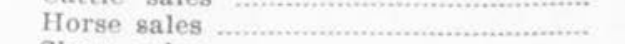 & $\begin{array}{r}223 \\
32\end{array}$ & & $\begin{array}{r}101 \\
29\end{array}$ & & $\begin{array}{r}107 \\
59\end{array}$ \\
\hline Sheep sales ............. & 12 & & - & & 5 \\
\hline Swine sales ............... & 213 & & 72 & & 96 \\
\hline Other receipts & 423 & & 273 & & 235 \\
\hline Increase in livestock inventory ................... & 156 & & $\overline{0}$ & & 22 \\
\hline Increase in machinery inventory............ & 51 & & 51 & & 28 \\
\hline Increase in feed and supplies.................. & 168 & & 22 & & 112 \\
\hline \multirow{2}{*}{\multicolumn{6}{|c|}{$\begin{array}{l}\text { Total Farm Receipts..... } \\
\text { Farm Expenses }\end{array}$}} \\
\hline & & & & & \\
\hline Blacksmith and machine work....... & 115 & $\mathbf{3}$ & 58 & $\$$ & 67 \\
\hline Hired labor & 72 & & 63 & & 58 \\
\hline Mach., bldg., and fence material...... & 115 & & 86 & & 73 \\
\hline 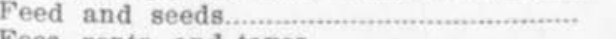 & 24 & & 90 & & 45 \\
\hline 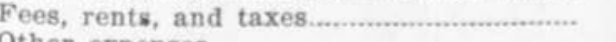 & 111 & & 81 & & 85 \\
\hline Other expenses .......................... & 43 & & 26 & & 30 \\
\hline 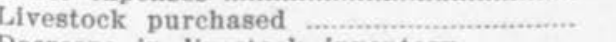 & 146 & & 60 & & 138 \\
\hline Decrease in livestock inventory ................ & $\overline{15}$ & & 109 & & $\overline{-1}$ \\
\hline Decrease in land and buildings................. & 15 & & 24 & & 16 \\
\hline 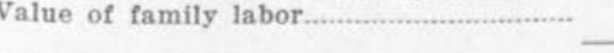 & 79 & & 81 & & 63 \\
\hline Total Farm Expenses. & 720 & $\$$ & 678 & $\$$ & 575 \\
\hline \multirow{2}{*}{\multicolumn{6}{|c|}{$\begin{array}{l}\text { Farm, Income (receipts-expenses) .......... } 2,351 \\
\text { Interest on Total Farm Capital (at } 8\end{array}$}} \\
\hline & & & 786 & & 639 \\
\hline Labor Income ....... & 1.702 & $\$$ & -508 & $\$$ & 368 \\
\hline
\end{tabular}


Table XXVIII.-Business Statement of Farms of Pleasant Grove Area, Utah County, Utah, 1916, Showing Type of Farming

Average or̉ 10 Average of 10 Average better-paying least-profitable of all 57 farms farms farms

\section{Farm Capital}

Real estate

Land

Buildings

Livestock

Machinery

Feed and supplies.

Total Farm Capital Farm Receipts

Crops

Potatoes

Grain

Hay

Sugar-beets

Fruit

Other erops

Livestock

Dairy products

Poultry and egg sales.

Cattle sales

Horse sales

Sheep sales

Swine sales

Other receipts

merease in livestock inventory..................

Increase in machinery inventory

Increase in feed and supplies...

Increase in land and buildings...

Total Farm Receipts

\section{Farm Expenses}

Blacksmith and machine work

Hired labor

Mach., bldg., and fence materia................ 130

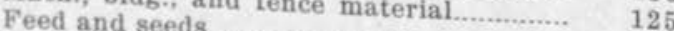

Fees, rents, and taxes.

Other expenses

Livestock purchased

chased

Value of family lack inventory.......................

family labor.

Total Farm Expenses...

Farm Income (Receipts-expenses). Interest on Total Farm Capital
per cent)

Labor Income
1,164

\section{\$ 3,642 \\ 1,030 \\ 536 \\ 182 \\ 287 \\ $\$ 5,677$}

\$ 5,019 1,235

892

350

296

$\$ 7,792$

$\begin{array}{rr}\$ & 365 \\ . . & 237 \\ . . & 51 \\ . & 352 \\ . & 98 \\ . & 25\end{array}$

\$ 17

\$ 133

91

96

185

11

361

75

627

-

330

244

211

28

176

36

3,217

6

20

47

40

1

31

71

$-$

50

30

20

$\$ 716$

\$ 1,649

\& 38

77

87

58

128

28

111

81

70

$\$ 492$

$\$ 608$

$\$ 224$

\& 1,041

454

623

940

\& 1,113 
Table XXIX. - Average farm prices in Utah, December 1, 1s 8 -1918( 1 )

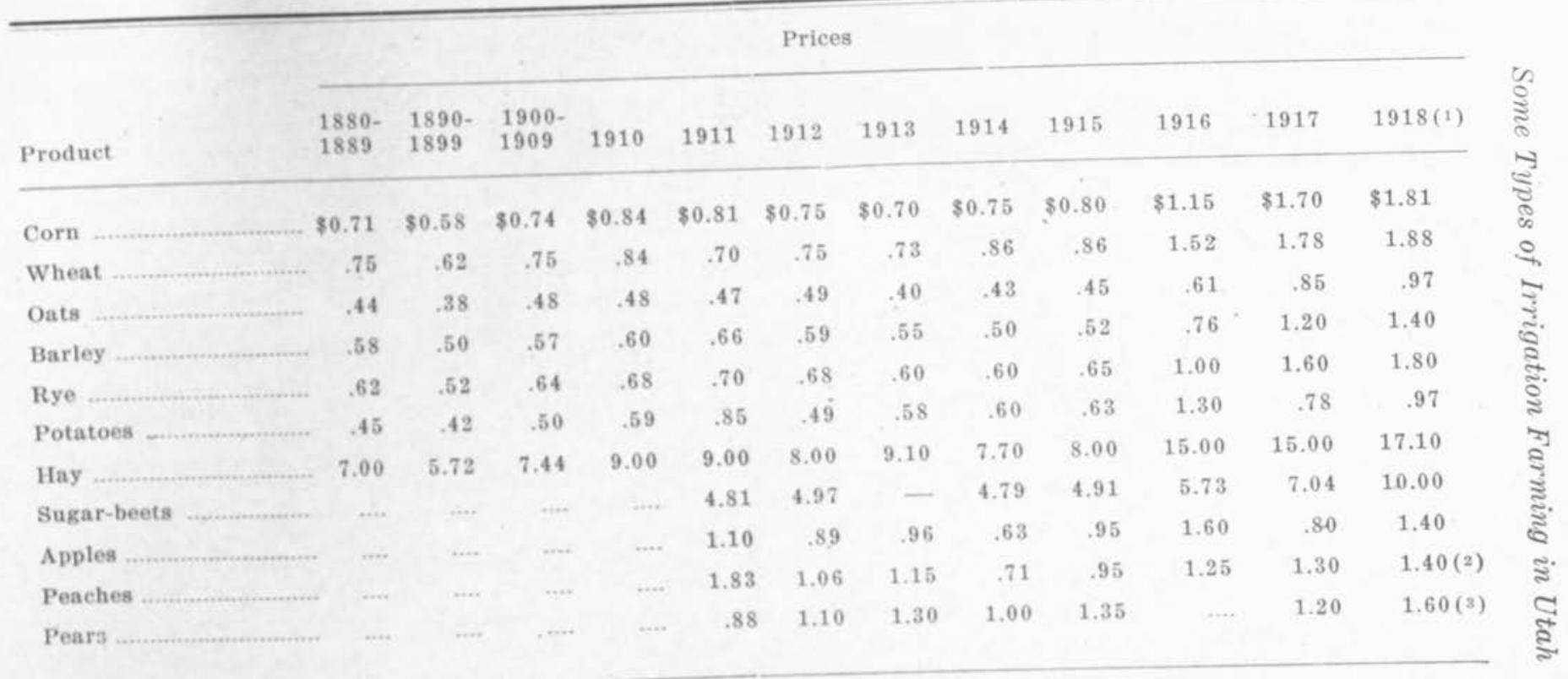

(1)U. S. D. A., Yearbook, 1917, Dec. 1, Farm Prices from $1880-1917$.

Prices for 1918 were taken from U. S. D. A.. Monthly Crop Report, Dec., 1918.

(2) Farm prices on Oct. 15, 1918 .

(a) Farm prices on Nov, 15, 1918. 


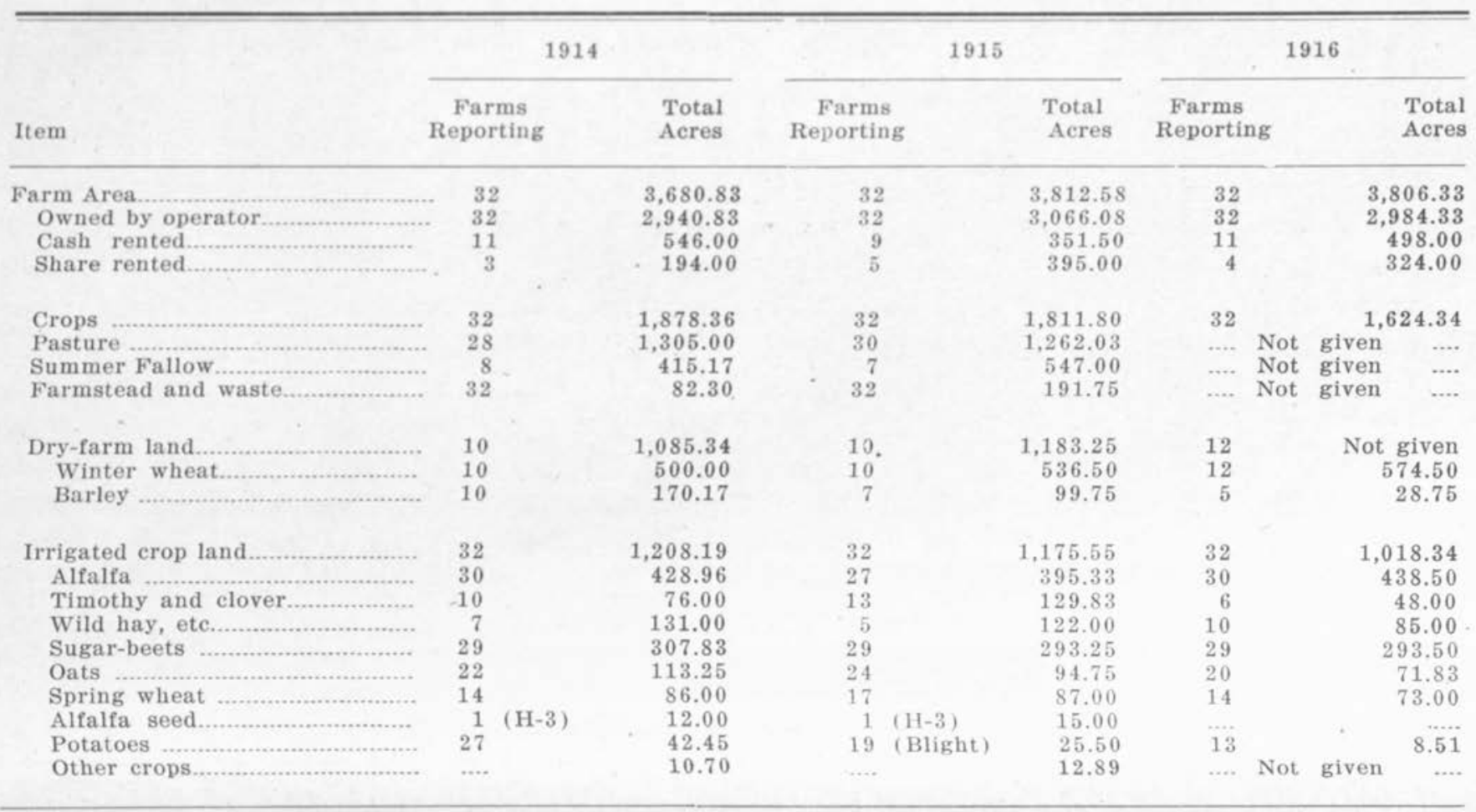


Table XXXI.-Tenure of Farms in Utah, by Counties, $1880^{(1)}$

\begin{tabular}{|c|c|c|c|c|c|}
\hline \multirow{2}{*}{ Area } & \multirow{2}{*}{$\begin{array}{l}\text { Number } \\
\text { of } \\
\text { Farms }\end{array}$} & \multirow{2}{*}{$\begin{array}{l}\text { Average } \\
\text { Size } \\
\text { (Acres) }\end{array}$} & \multirow{2}{*}{$\begin{array}{l}\text { Farms } \\
\text { Owned }\end{array}$} & \multicolumn{2}{|c|}{ Farms Rented for } \\
\hline & & & & Cash & Share \\
\hline The State........... & 9,452 & 69 & 9,019 & 60 & 373 \\
\hline \multicolumn{6}{|c|}{ County } \\
\hline Beaver .................... & 211 & 60 & 204 & .... & 7 \\
\hline Boxelder .......... & 533 & 88 & 486 & 8 & 39 \\
\hline Cache....................... & 998 & 85 & 943 & 22 & 33 \\
\hline Davis .................... & 560 & 101 & 531 & 1 & 28 \\
\hline Emery ................. & 84 & 127 & 81 & $\ldots .$. & 3 \\
\hline \multirow{5}{*}{ 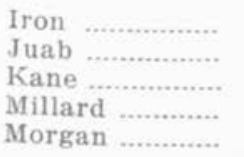 } & 217 & 55 & 202 & 2 & 13 \\
\hline & 185 & 63 & 185 & $\ldots$. & $\ldots$ \\
\hline & 214 & 32 & 200 & $\ldots .$. & 14 \\
\hline & 235 & 62 & 224 & $\ldots$. & 11 \\
\hline & 182 & 61 & 174 & $\ldots$. & 8 \\
\hline \multirow{5}{*}{$\begin{array}{l}\text { Piute } \\
\text { Rich .............. } \\
\text { Salt Lake......... } \\
\text { San Juan........ } \\
\text { Sanpete }\end{array}$} & 134 & 118 & 130 & $\ldots$. & 4 \\
\hline & 153 & 135 & 147 & 1 & 5 \\
\hline & 961 & 53 & 910 & 10 & 41 \\
\hline & 31 & 43 & 31 & & \\
\hline & 1,015 & 49 & 999 & 5 & 11 \\
\hline \multirow{5}{*}{$\begin{array}{l}\text { Sevier } \\
\text { Summit } \\
\text { Tooele } \\
\text { Tinta }\end{array}$} & 429 & 53 & 402 & w. & 27 \\
\hline & 298 & 96 & 287 & 2 & 9 \\
\hline & 304 & 75 & 275 & 1 & 28 \\
\hline & & 21 & & $\ldots$ & 3 \\
\hline & 1,321 & 68 & 1,271 & 4 & 46 \\
\hline \multirow{3}{*}{$\begin{array}{l}\text { Wasatch } \\
\text { Washington ..... } \\
\text { Weber . . }\end{array}$} & 339 & 59 & 330 & 1 & 8 \\
\hline & 193 & 38 & 190 & & 3 \\
\hline & 848 & 68 & 810 & 3 & 35 \\
\hline
\end{tabular}

(1) 1880 U. S. Census. 
Table XXXII.-Tenure of Farms in Utah, by Counties, $1890(1)$

\begin{tabular}{|c|c|c|c|c|c|c|c|c|}
\hline \multirow[b]{2}{*}{ Area } & \multirow{2}{*}{ 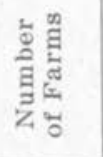 } & \multirow{2}{*}{ 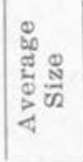 } & \multirow{2}{*}{ 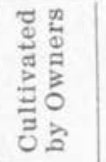 } & \multirow[b]{2}{*}{ 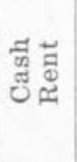 } & \multirow[b]{2}{*}{ 营 } & \multicolumn{3}{|c|}{ Percentages } \\
\hline & & & & & & $\frac{⿱ 乛}{ٍ}$ & 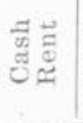 & 总 \\
\hline The State.................. & 10,517 & 126 & 9,974 & 121 & 422 & 94.8 & 1.15 & 4.01 \\
\hline $\begin{array}{l}\text { Counties } \\
\text { Beaver .... }\end{array}$ & & & & & & & & \\
\hline Boxelder & $\begin{array}{l}210 \\
478\end{array}$ & $\begin{array}{r}77 \\
900\end{array}$ & $\begin{array}{l}197 \\
463\end{array}$ & $\begin{array}{l}1 \\
4\end{array}$ & 12 & 93.81 & .48 & \\
\hline Cache & 1,065 & $\begin{array}{r}94 \\
\end{array}$ & $\begin{array}{l}463 \\
979\end{array}$ & $\begin{array}{r}4 \\
31\end{array}$ & 11 & 96.86 & & $\begin{array}{l}2.30 \\
5.16\end{array}$ \\
\hline Davis ...... & 682 & 120 & 634 & $\begin{array}{r}31 \\
9\end{array}$ & $\begin{array}{l}55 \\
39\end{array}$ & $\begin{array}{l}91.93 \\
92.96\end{array}$ & $\begin{array}{l}2.91 \\
1.32\end{array}$ & $\begin{array}{l}5.16 \\
5.72\end{array}$ \\
\hline Emery & 266 & 111 & 256 & 2 & $\begin{array}{r}39 \\
8\end{array}$ & $\begin{array}{l}92.96 \\
96.24\end{array}$ & $\begin{array}{r}1.52 \\
.75\end{array}$ & 3.01 \\
\hline Garfiel & 93 & 77 & 91 & & 2 & 97.85 & & 2.15 \\
\hline Ir & 56 & 108 & 52 & 1 & 3 & 92.86 & 1.78 & 5.36 \\
\hline $\begin{array}{l}\text { Iron } \\
\text { Juab }\end{array}$ & 198 & 29 & 193 & & 5 & 97.47 & & $2.5 ?$ \\
\hline Kane & $\begin{array}{r}97 \\
120\end{array}$ & 157 & 93 & 1 & 3 & 95.88 & 1.03 & 3.09 \\
\hline Milla & 1 & 66 & 112 & & 8 & 93.33 & & 6.67 \\
\hline Iorgan & 360 & 135 & 302 & & 4 & 98.69 & & 1.31 \\
\hline Piute.... & 238 & 85 & 211 & & 27 & 88.66 & & 11.34 \\
\hline Rich & $\begin{array}{l}143 \\
192\end{array}$ & 126 & 137 & .... & 6 & 95.80 & & 4.20 \\
\hline Salt Lake. & $\begin{array}{r}193 \\
1,366\end{array}$ & $\begin{array}{r}491 \\
54\end{array}$ & $\begin{array}{l}188 \\
254\end{array}$ & 2 & 3 & 97.41 & 1.04 & 1.5 \\
\hline San . & & & & & 67 & 91.80 & 3.29 & 4.91 \\
\hline Sanpete & & 108 & 38 & & & 100.00 & & \\
\hline Sevier & $\begin{array}{r}1,191 \\
312\end{array}$ & $\begin{array}{l}80 \\
80\end{array}-1$ & 1,163 & 4 & 24 & 97.65 & .34 & 2.01 \\
\hline Summit & $\begin{array}{l}312 \\
362\end{array}$ & $\begin{array}{l}88 \\
97\end{array}$ & 297 & & 15 & 95.19 & & 4.8 \\
\hline Tooele . & 301 & $\begin{array}{r}97 \\
137\end{array}$ & $\begin{array}{l}345 \\
281\end{array}$ & 2 & 15 & 95.31 & .55 & 4.14 \\
\hline Uinta & & & & & 15 & 93.36 & 1.66 & 4.98 \\
\hline Utah & $\begin{array}{r}186 \\
1.198\end{array}$ & 106 & 186 & & & 100.00 & & \\
\hline Wasateh & $\begin{array}{r}1,198 \\
289\end{array}$ & 57 & 1,159 & 7 & 32 & 96.75 & .58 & $2.7 \mathrm{t}$ \\
\hline Washington . & $\begin{array}{l}289 \\
187\end{array}$ & 68 & $\begin{array}{l}277 \\
181\end{array}$ & … & 16 & 95.85 & 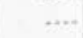 & $4.1:$ \\
\hline Weber .................... & 942 & $\begin{array}{l}20 \\
63\end{array}$ & $\begin{array}{l}181 \\
885\end{array}$ & 7 & $\begin{array}{r}6 \\
-5\end{array}$ & 96.79 & & 3.21 \\
\hline & & & & $\gamma$ & 50 & 93.95 & .74 & 5.31 \\
\hline
\end{tabular}

(1) 1890 U. S. Census. 
Table XXXIII.-Tenure of Farms in Utah by Counties, $1900(1)$

\begin{tabular}{|c|c|c|c|c|c|c|c|c|}
\hline Area & 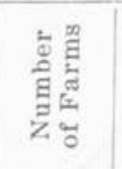 & 边芯 & 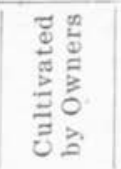 & 递 & 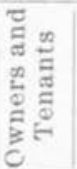 & 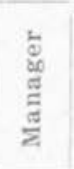 & 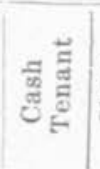 & 总 \\
\hline The State.................. & $19, \overline{387}$ & 212.4 & 15.177 & 2,051 & 135 & 311 & 506 & 1,207 \\
\hline $\begin{array}{l}\text { Counties } \\
\text { Beaver }\end{array}$ & 301 & 97.1 & 216 & 16. & & & 2 & 22 \\
\hline $\begin{array}{l}\text { Beaver ..... } \\
\text { Boxelder. }\end{array}$ & 1,017 & 561.1 & 813 & 115 & 6 & 21 & 15 & $\begin{array}{l}22 \\
47\end{array}$ \\
\hline Cache ...... & 1,795 & 176.4 & 1,446 & 236 & 6 & 16 & 15 & 76 \\
\hline Carbon .. & 144 & 194.3 & 112 & 10 & 4 & 5 & 7 & 6 \\
\hline Davis ............ & 938 & 240.9 & 611 & 217 & 11 & 16 & 43 & 40 \\
\hline Emery . & 458 & 118.3 & 400 & 12 & & 3 & 6 & 37 \\
\hline Garfield & 237 & 121.5 & 228 & 3 & 2 & & 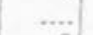 & 4 \\
\hline Grand ... & 121 & 129.6 & 100 & 5 & .. & 5 & 2 & 9 \\
\hline Iron & 235 & 100.3 & 197 & 2 & 6 & 13 & 2 & 15 \\
\hline Juab & 356 & 222.8 & 249 & 62 & 3 & 3 & 4 & 35 \\
\hline Kane & 213 & 112.4 & 188 & 17 & & 4 & & 4 \\
\hline Millard & 676 & 159.8 & 575 & 52 & 5 & 7 & 10 & 27 \\
\hline Morgan & 299 & 463.6 & 217 & 38 & 3 & 12 & 7 & 22 \\
\hline Piute ........... & 189 & 145.8 & 159 & 6 & 1 & 1 & 5 & 17 \\
\hline Rich ……............ & 276 & 582.8 & 230 & 3 & 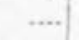 & 21 & 4 & 18 \\
\hline Salt Lake. & 2,208 & 125.0 & 1,561 & 250 & 17 & 41 & 152 & 187 \\
\hline San Juan... & 85 & 221.7 & 66 & 6 & 1 & 7] & 5 & \\
\hline Sanpete ... & 1,618 & 116.6 & 1,313 & 115 & 5 & 30 & 11 & 144 \\
\hline Sevier ... & 946 & 79.5 & 810 & 64 & 5 & 17 & 8 & 42 \\
\hline Summit .... & 608 & 476.4 & 526 & 19 & $\cdots$ & 19 & 12 & 32 \\
\hline Tooele & 487 & 238.2 & 422 & 12 & 2 & 16 & 9 & 26 \\
\hline Vinta . & 559 & 608.8 & 466 & 29 & 12 & 7 & 4 & 41 \\
\hline Utah & 2,760 & 81.1 & 2,041 & 416 & 30 & 22 & 56 & 195 \\
\hline 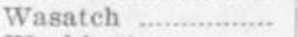 & 492 & 190.0 & 386 & 50 & s & 4 & 7 & 45 \\
\hline Washington & 477 & 45.9 & 355 & 99 & 5 & 4 & 2 & 12 \\
\hline Wayne... & 271 & 108.3 & 215 & 15 & 2 & 2 & 6 & 31 \\
\hline Weber .... & 1,479 & 126.2 & 1,098 & 181 & 9 & 13 & 105 & 73 \\
\hline
\end{tabular}

(1) 1910 V. S. Census. 
Table XXXIV.-Tenure of Farms in Utah, by Counties, by Percentages, $1900(1)$

\begin{tabular}{|c|c|c|c|c|c|c|c|c|}
\hline \multirow[b]{2}{*}{ Area } & \multirow[b]{2}{*}{ 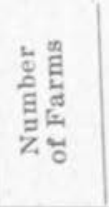 } & \multirow[b]{2}{*}{ 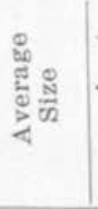 } & \multicolumn{6}{|c|}{ Percentages } \\
\hline & & & 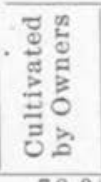 & 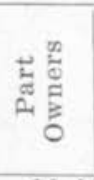 & 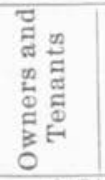 & 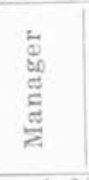 & 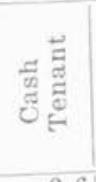 & 莺 \\
\hline The State...... & 19,387 & 212.4 & 78.3 & 10.6 & 0.7 | & 1.6 & 2.6 & 6.2 \\
\hline Counties & & & & & & & & \\
\hline (................. & 301 & 97.1 & 86.7 & 5.3 & & & 0.7 & 7. \\
\hline Boxelder ....... & 1,017 & 561.1 & 79.9 & 11.3 & 0.6 & 2.1 & 1.5 & 4 \\
\hline Cache ............... & 1,795 & 176.4 & 80.6 & 13.2 & 0.3 & 0.9 & 0.8 & 4.2 \\
\hline Carbon ............ & 144 & 194.3 & 77.8 & 6.9 & 2.8 & 3.5 & 4.8 & 4.2 \\
\hline Davis ............ & 938 & 240.9 & 65.1 & 23.1 & 1.2 & 1.7 & 4.6 & 4.3 \\
\hline Emery .. & 458 & 118.3 & 87.3 & 2.6 & & 0.7 & 1.3 & 8.1 \\
\hline Garfield ......... & 237 & 121.5 & 96.2 & 1.3 & 0.8 & & & 1. \\
\hline Grand ............ & 121 & 129.6 & 82.7 & 4.1 & $\ldots$. & 4.1 & 1.7 & 2. \\
\hline Iron & 235 & 100.3 & 83.8 & 0.9 & 2.6 & 5.5 & 0.8 & 6. \\
\hline Juab ................ & 356 & 222.8 & 70.0 & 17.4 & 0.9 & 0.8 & 1.1 & 9.8 \\
\hline Kane & 213 & 112.4 & 88.2 & 8.0 & & 1.9 & & 1. \\
\hline Millard ......... & 676 & 159.8 & 85.1 & 7.7 & 0.7 & 1.0 & 1.5 & $\pi$ \\
\hline Morgan ........... & 299 & 463.6 & 72.6 & 12.7 & 1.0 & 4.0 & 2.3 & 7. \\
\hline Piute .............. & 189 & 145.8 & 84.1 & 3.2 & 0.5 & 0.5 & 2.7 & 9. \\
\hline Rich ................. & 276 & 582.8 & 83.3 & 1.1 & $\cdots$. & 7.6 & 1.5 & 6 \\
\hline Salt Lake...... & 2,208 & 125.0 & 70.7 & 11.3 & 0.8 & 1.8 & 6.9 & 8.5 \\
\hline San Juan & 85 & 221.7 & 77.6 & 7.1 & 1.2 & 8.2 & 5.9 & $\because 0$ \\
\hline Sanpete ......... & 1,618 & 116.6 & 81.1 & 7.1 & 0.3 & 1.9 & 0.7 & 8.9 \\
\hline Sevier ........... & 946 & 79.5 & 85.6 & 6.8 & 0.5 & 1.8 & 0.9 & 4.4 \\
\hline Summit ....... & 608 & 476.4 & 86.5 & 3.1 & $\ldots$. & 3.1 & 2.0 & 5.3 \\
\hline Tooele & 487 & 238.2 & 86.7 & 2.5 & 0.4 & 3.3 & 1.8 & 5.3 \\
\hline Uinta & 559 & 608.8 & 83.4 & 5.2 & 2.1 & 1.3 & 0.7 & 7.3 \\
\hline Utah ............... & 2,760 & 81.1 & 73.9 & 15.1 & 1.1 & 0.8 & 2.0 & 7.1 \\
\hline Wasatch ....... & 492 & 190.0 & 78.5 & 10.2 & $\ldots$. & 0.8 & 1.4 & 9.1 \\
\hline Washington .. & 477 & 45.9 & 74.4 & 20.8 & 1.1 & 0.8 & 0.4 & 05 \\
\hline Wayne ............. & 271 & 108.3 & 79.3 & 5.5 & 0.8 & 0.7 & 2.2 & 11.5 \\
\hline Weber ............ & 1,479 & 126.2 & 74.3 & 12.2 & 0.6 & 0.9 & 7.1 & 4.9 \\
\hline
\end{tabular}

(1) 1910 U. S. Cênsus. 
Table XXXV.-Tenure of Farms in Utah by Counties, 1910(2)

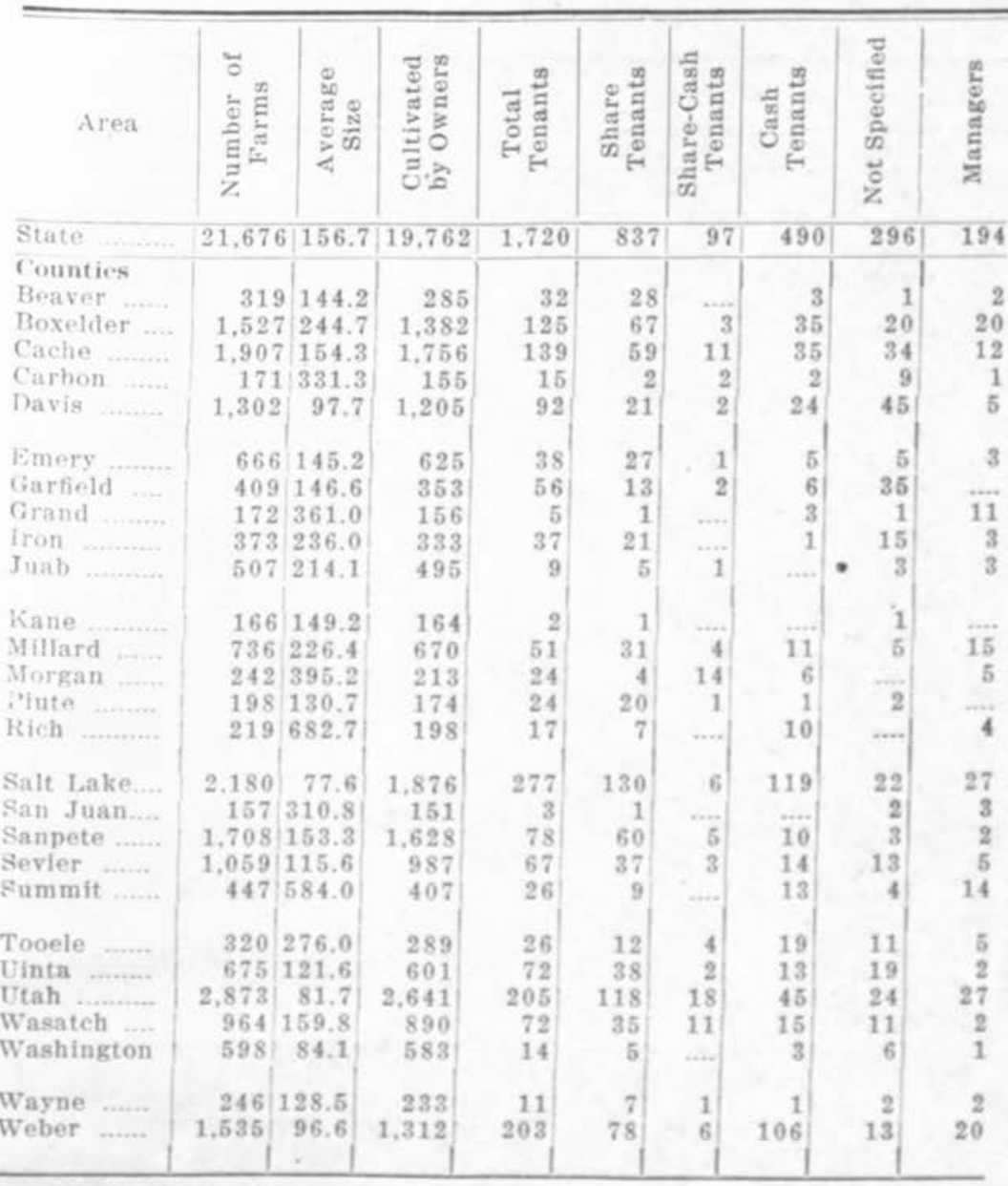

(1) 1910 U. S. Census. 
Table XXXVI.-Percentage of all Farms Operated by Owners, Utah, 1889 and 1909 (1)

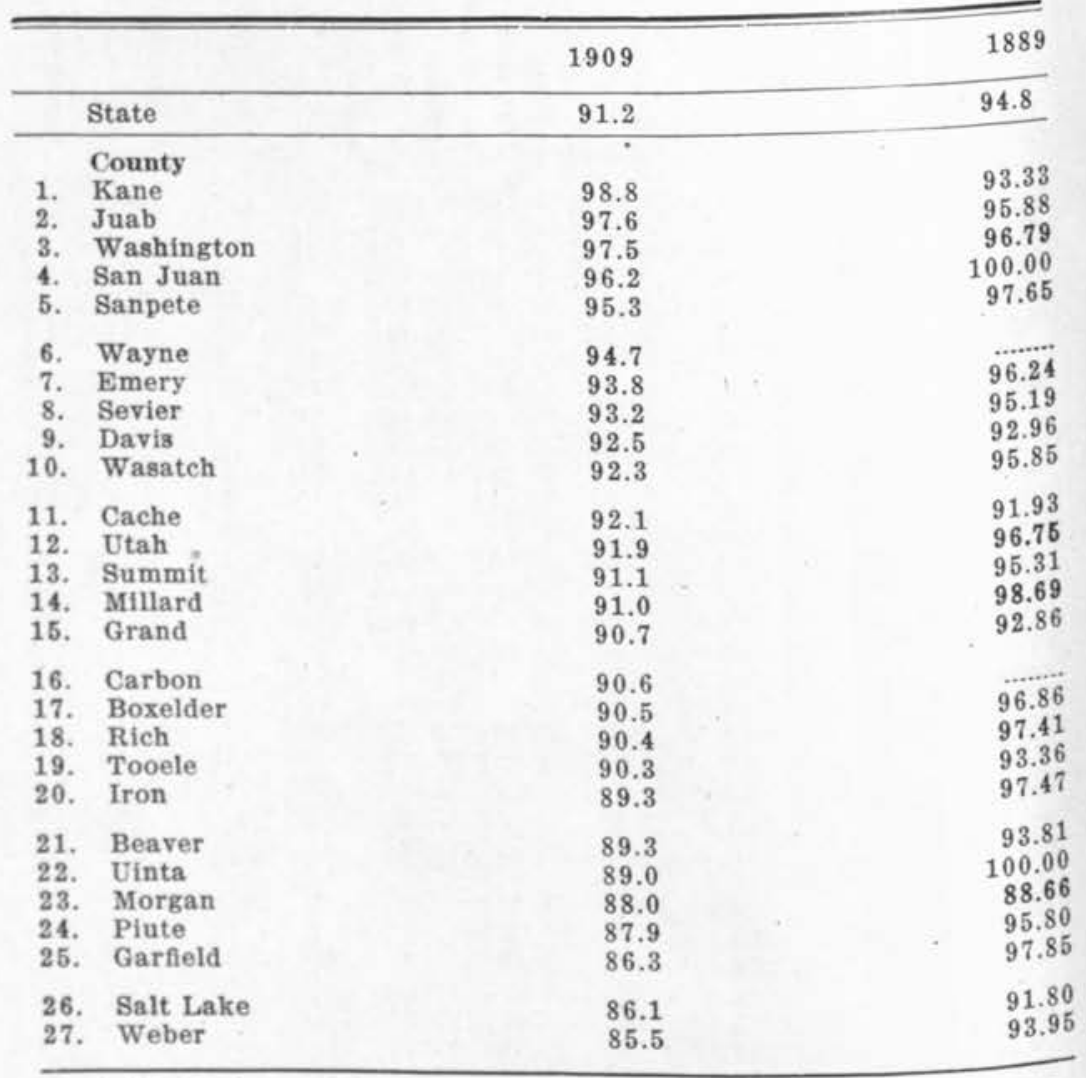

(1) U. S. Census Reports. 
Table XXXVII.-Dates of Farm Crop Operations in Eight Areas of Utah(1)

\begin{tabular}{|c|c|c|c|c|c|c|c|c|}
\hline Operation & Cache & Salt Lake & Utah & Carbon & Emery & Millard & Sevier & Beaver \\
\hline Winter wheat (seeding) ....................... & $9 / 15(2)$ & $9 / 15$ & $9 / 15$ & $9 / 15$ & $9 / 20$ & $9 / 15$ & $9 / 20$ & $9 / 1$ \\
\hline Winter wheat, date when harvest begins. & $7 / 15$ & $7 / 9$ & $7 / 9$ & $7 / 10$ & $7 / 14$ & $7 / 14$ & $7 / 14$ & $7 / 10$ \\
\hline Winter wheat, harvest general.............. & $7 / 15$ & $7 / 15$ & $7 / 15$ & $8 / 10$ & $8 / 10$ & $7 / 18$ & $7 / 18$ & $7 / 20$ \\
\hline Spring wheat, seeding begins.... & $4 / 2$ & $4 / 2$ & $4 / 2$ & $4 / 1$ & $4 / 1$ & $4 / 1$ & $4 / 1$ & $4 / 1$ \\
\hline Spring wheat, seeding general. & $4 / 28$ & $4 / 20$ & $4 / 20$ & $4 / 14$ & $4 / 14$ & $4 / 10$ & $4 / 10$ & $4 / 9$ \\
\hline Spring wheat, harvest begins... & $8 / 10$ & $8 / 6$ & $8 / 6$ & $8 / 1$ & $8 / 1$ & $8 / 6$ & $7 / 20$ & $7 / 18$ \\
\hline Spring wheat, harvest general. & $9 / 15$ & $9 / 15$ & $9 / 15$ & $9 / 12$ & $9 / 12$ & $9 / 10$ & $9 / 12$ & $9 / 12$ \\
\hline Winter oats, sowing begins..... & $8 / 20$ & $9 / 1$ & $9 / 1$ & $9 / 15$ & $9 / 15$ & $9 / 18$ & $9 / 18$ & $9 / 18$ \\
\hline Winter oats, harvest begins. & $7 / 1$ & $7 / 15$ & $7 / 15$ & $7 / 25$ & $7 / 25$ & $7 / 25$ & $7 / 25$ & $7 / 25$ \\
\hline Spring oats, seeding begins... & $4 / 10$ & $3 / 20$ & $3 / 20$ & $4 / 10$ & $4 / 10$ & $3 / 20$ & $4 / 10$ & $4 / 10$ \\
\hline Spring oats, seeding general. & $4 / 20$ & $4 / 15$ & $4 / 25$ & $4 / 15$ & $4 / 15$ & $4 / 25$ & $4 / 15$ & $4 / 15$ \\
\hline Spring oats, harvest begins. & $8 / 10$ & $8 / 1$ & $8 / 1$ & $8 / 4$ & $8 / 1$ & $7 / 25$ & $8 / 1$ & $8 / 1$ \\
\hline Spring oats, harvest general. & $9 / 2$ & $8 / 25$ & $8 / 25$ & $8 / 27$ & $8 / 27$ & $8 / 25$ & $8 / 24$ & $8 / 22$ \\
\hline Corn, planting beging & $4 / 25$ & $5 / 5$ & $5 / 5$ & $5 / 7$ & $5 / 7$ & $5 / 15$ & $5 / 12$ & $5 / 12$ \\
\hline Corn, cutting siNage begins....... & $8 / 28$ & $9 / 1$ & $9 / 1$ & $9 / 1$ & $9 / 1$ & $9 / 1$ & $9 / 1$ & $9 / 1$ \\
\hline Corn, cutting and shocking begins. & $9 / 5$ & $9 / 15$ & $9 / 15$ & $9 / 1$ & $9 / 1$ & $9 / 1$ & $9 / 1$ & $9 / 1$ \\
\hline Corn, husking and Jerking begins. & $10 / 1$ & $10 / 10$ & $10 / 10$ & $9 / 10$ & $9 / 10$ & $9 / 20$ & $9 / 5$ & $9 / 5$ \\
\hline Kafir, harvest begins. & $8 / 1$ & $8 / 10$ & $8 / 10$ & $8 / 20$ & $9 / 1$ & $9 / 1$ & $9 / 15$ & $9 / 15$ \\
\hline Timothy and Clover, first cutting beging & $7 / 1$ & $7 / 5$ & $7 / 5$ & $7 / 5$ & $7 / 5$ & $7 / 5$ & $7 / 10$ & $7 / 10$ \\
\hline Alfalfa, first cutt & $6 / 20$ & $6 / 5$ & $6 / 5$ & $6 / 20$ & $6 / 20$ & $6 / 20$ & $6 / 20$ & $6 / 20$ \\
\hline Alfalfa, second cutting ................ & $8 / 10$ & $8 / 1$ & $8 / 1$ & $8 / 5$ & $8 / 5$ & $8 / 5$ & $8 / 1$ & $8 / 1$ \\
\hline Early potatoes, pla & $4 / 11$ & $4 / 10$ & $4 / 10$ & $4 / 25$ & $4 / 25$ & $4 / 25$ & $4 / 15$ & $4 / 15$ \\
\hline Early potatoes, digging beg & $7 / 6$ & $6 / 5$ & $6 / 5$ & $7 / 4$ & $7 / 4$ & $7 / 4$ & $7 / 10$ & $7 / 10$ \\
\hline Northern Commercial, plant & $5 / 20$ & $5 / 20$ & $5 / 20$ & $5 / 11$ & $5 / 11$ & $5 / 11$ & $4 / 25$ & $4 / 25$ \\
\hline Northern Commercial, digging begins..................... & $10 / 6$ & $10 / 6$ & $10 / 6$ & $10 / 20$ & $10 / 20$ & $10 / 20$ & $10 / 20$ & $10 / 20$ \\
\hline Sugar-beets, planting begins.......... & $4 / 1-10$ & $4 / 1-10$ & $4 / 1-10$ & & & $4 / 1-15$ & $4 / 1-10$ & \\
\hline -beets, thinn & $5 / 20$ & $5 / 15$ & $5 / 15$ & $5 / 1$ & $5 / 1$ & $5 / 1$ & $5 / 20$ & $5 / 2$ \\
\hline Sugar-beets, pulling begins..... & $9 / 25$ & $10 / 1$ & $10 / 1$ & $10 / 5$ & $10 / 5$ & $10 / 5$ & $9 / 25$ & $9 / 25$ \\
\hline Field beans, planting begins... & $5 / 10$ & $5 / 10$ & $5 / 10$ & $4 / 15$ & $4 / 15$ & $4 / 15$ & $5 / 10$ & $5 / 10$ \\
\hline Fleld beans, harv & $9 / 10$ & $8 / 10$ & $8 / 10$ & $9 / 10$ & $9 / 10$ & $9 / 10$ & $9 / 20$ & $9 / 20$ \\
\hline Elberta peach picking begins. & $9 / 5$ & $9 / 1$ & $9 / 1$ & $9 / 10$ & $9 / 10$ & $9 / 10$ & $9 / 10$ & $9 / 10$ \\
\hline Ben Davis apples. & $10 / 10$ & $10 / 15$ & $10 / 15$ & & & ............ & & \\
\hline Tomatoes... & $8 / 25$ & $8 / 25$ & $8 / 25$ & & & & & \\
\hline
\end{tabular}

(1) Baker, O. E., and others, U. S. D. A., Yearbook, 1917, pp. 537-591, or Yearbook separate, No. 758.

(2) First figure represents the number of the month; the second figure the date of month. 
Comparison of the average crop yields in Utah with the average yields of Iowa and the United States. Yields used are for the ten years $1905-14$ as given in the 1914 yearbook of the United States Department of Agriculture.

Table XXXVIII.-Average Yields of Seven Important Utah Crops

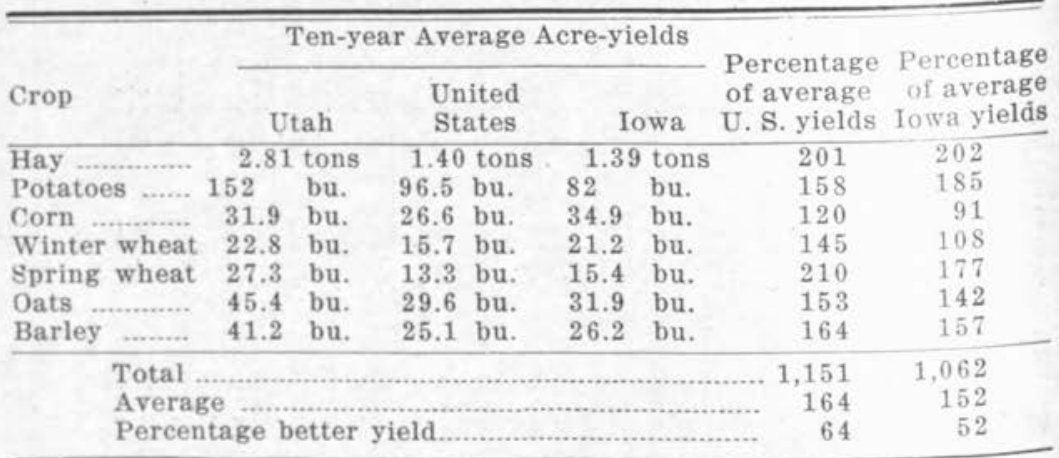

Table XXXIX.-Percentage Yield, or Crop Index, Based on Average U. S. Yields

\begin{tabular}{|c|c|c|c|}
\hline Crop & $\begin{array}{l}\text { Acres Grown } \\
\text { in Utah, } 1909\end{array}$ & $\begin{array}{r}\text { Comparative } \\
\text { Yield Per Acre }\end{array}$ & $\begin{array}{l}\text { Acres Multiplied by } \\
\text { the Percentage Yield }\end{array}$ \\
\hline Hay …t........................... & 405,394 & 201 & $81,484,194$ \\
\hline Potatoes & .... 14,210 & 158 & $2,245,180$ \\
\hline Corn & …. $\quad 7,267$ & 120 & 872,040 \\
\hline Winter wheat............ & 119,948 & 145 & $17,392,460$ \\
\hline Spring wheat ............. & $\ldots \quad 58,442$ & 210 & $12,272,820$ \\
\hline Oats & 80,816 & 153 & $12,364,848$ \\
\hline Barley & 26,752 & 164 & $4,389,328$ \\
\hline Total & $\ldots 712,829$ & & $131,020,870$ \\
\hline Percentage & yield, or crop & lex. & $\frac{131,020,870}{712,829}=184$ \\
\hline
\end{tabular}

Table XL.-Percentage Yield, or Crop Index, Based on Average Iowa Yields

\begin{tabular}{|c|c|c|}
\hline $\begin{array}{l}\text { Acres Grown } \\
\text { in Utah, } 1909\end{array}$ & $\begin{array}{r}\text { Comparative } \\
\text { Yield Per Acre }\end{array}$ & $\begin{array}{l}\text { Acres Multiplied by } \\
\text { the Percentage Yield }\end{array}$ \\
\hline Hay …........................ 405,394 & 202 & $81,889,588$ \\
\hline Potatoes …................... 14,210 & 185 & $2,628,850$ \\
\hline Corn & 91 & 661,297 \\
\hline Winter wheat ........... 119,948 & 108 & $12,954,384$ \\
\hline Spring wheat $\ldots . . . . \ldots \ldots \ldots . .58,442$ & 177 & $10,344,234$ \\
\hline Oats _..................... 80,816 & 142 & $11,475,872$ \\
\hline Barley ....................... 26,752 & 157 & $4,200,064$ \\
\hline Total................ & & $124,154,289$ \\
\hline \multicolumn{2}{|c|}{ Percentage yield, or crop index. } & $\frac{124,154,289}{712,829}$ \\
\hline
\end{tabular}




\section{INDEX}

\section{ILLUSTRATIONS}

1. Location of the 8 Areas Investigated, Utah.

2. Average Annual Precipitation in Utah.

3. Average Annual Precipitation in inches in areas investigated, Utah..21

4. Average Precipitation in Crop Growing Season, Utah.......................21

5. Mean Annual Temperature, Utah ...................................................21

6. Average Days in Crop-growing Season, Utah..................................22

7. Date of Average Last Killing Frost in Spring, Utah..........................22

8. Date of Average First Killing Frost in Autumn, Utah........................22

9. Latest Date of Killing Frost in Spring, Utah ........................................22

10. Earliest Date of Killing Frost in Autumn, Utah....................................23

11. Highest Temperatures Recorded, Utah.................................................23

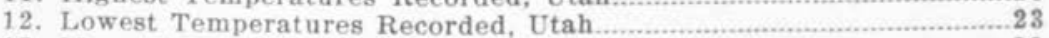

13. Mountains, Valleys, Lakes and Streams, Utah ......................................23

14. Extent of Old Lake Bonneville in Utah, where Soils of the Great Interior Basin Originated.

15. Three General Soil Provinces in Utah..............................................25

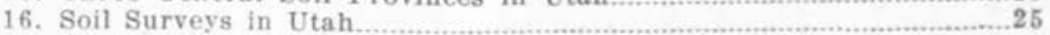

17. National Forests of Intermountain Region ..........................................26

18. Distribution of Population, by Counties, Utah...............................27

19. Density of Population, by Counties, Utah ......................................27

20. Railroads, Auto Roads, and National Forests, Utah........................38

21. Three Canals that Supply Irrigation Water for Hyde Park Farms, Cache County, Utah. 


\section{TABLES IN TEXT}

Table

Title

Page

I. Number of Farm Records Studied Each Year by Counties, Utah .......... 6

II. Number of Farm Records by Length of Record for Each County, Utah

III. Tenure and Use of Farm Land, 32 Farms, Hyde Park, Cache

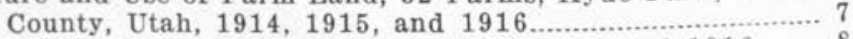

IV. Crop Yields on Hyde Park Farm, 1914, 1915, and $1916 \ldots \ldots .8$

V. Yield, Price, and Acre-value of Sugar-beets and Potatoes, 1914,1915 , and 1916, Hyde Park, Cache County, Utah..11

vI. Average Number of Units of Livestock on Farms, Hyde Park, Cache County, Utah, 1914 and $1915 \ldots \ldots \ldots \ldots \ldots \ldots \ldots \ldots \ldots \ldots \ldots \ldots \ldots . . . . . . . .13$

VII. Farm Receipts and Expenses, Average of 52 Farms, Hyde

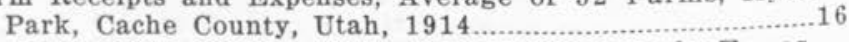

VIII. Average Value of Farm Machinery, Hyde Park Farms, Cache County, Utah, 1914,1915 , and $1916 \ldots \ldots \ldots \ldots \ldots \ldots . . .19$

IX. Soil Types of Farms Reporting, 52 Hyde Park Farms. Cache County, Utah.....................................................24

X. Value of all Domestic Animals on Farms and Ranges, by Counties, Utah, April 15, 1910 ...................................2 7

XI. Size of Farm Family, Acres Sugar-beets Raised, and Cows Milked, Hyde Park, Cache County, Utah, 1914 ..............28

XII. Size of Farm Family, Labor Income, Value of Unpaid Family Labor, Farm Income, and Family Income, Hyde Park, Cache County, Etah, 1914 .........................................30

XIII. Value of Farm Dwellings, 50 Farms, Hyde Park, Cache

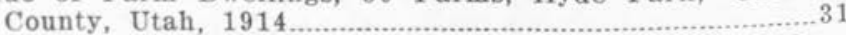

XIV. Relation of Value of Farm Home and Labor Income, Hyde Park, Cache County, Utah, 1914 ....................................... 31

XV. Relataion of Value of Farm Home and Labor Income, Hyde Park, Cache County, Utah, 1914 ..................................31

XVI. Relation of Value of Farm Home and Labor Income, Hyde Park, Cache County, Utah, 1914 .......................................31

XVII. Order of Crop Work at Hyde Park, Cache County, Utah.......33

XVIII. Persons 10 Years of Age or Over Engaged in Agriculture

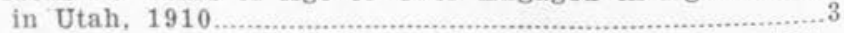

XIX. Average Cost of Hired Labor on Farms, by Counties, Utah, $1910 \ldots \ldots \ldots+\ldots$

XX. Wages of Farm Labor in Utah, 1866-1918 ............................... 36

XXI. Ratio of Agricultural Workers to Improved Area of Farms,

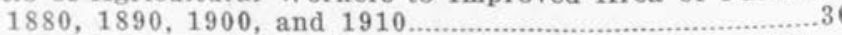

XXII. Tenure of Farms, Cache County, Utah, 1880, 1890, 1900 , and $1910 \ldots 40$

XXIII. Number and Kinds of Tenants, Cache County, Utah, 1880, 1890,1900 , and $1910 \ldots \ldots \ldots . . .41$

XXIV. Total Land Area, Land in Farms, and Improved Land in Farms, by Counties, Utah, 1909 .................................4

XXV. Percentage of Tenancy, Utah, 1880-1910 …............................42

XXVI. Total Value of Land and Buildings and Value of Land and Buildings per Farm and per Acre, 52 Farms. Hyde Park, Cache County, Utah, 1914 ...................................42

XXVII. Distance from Market and Land Values per Acre in 7 Areas, Utah, 1914 43

XXVIII. Percentage of Land in Farms and Farm Land Improved and Land Value per Acre, by Counties, Utah, 1910 ................44

XXIX. Relation of Improved Farm Land to Value of all Farm

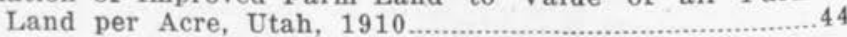


XXX. Average Values per Acre of Farm Land, Buildings, Machinery, and Livestock, by Counties, Utah, $1910 \ldots \ldots \ldots . .45$

XXXI. Average Value of Land and Buildings, per Acre, by Counties, Utah, Census Years.

XXXII. Crops Grown, Period of Irrigation, Number of Irrigations, Days between Irrigations, Logan and Richmond Canal, 1900

XXXIII. Farm Mortgages, Hyde Park, Cache County, Utah, 1914 ...52

XXXIV. Mortgage Debt of Farms by Counties, Utah, $1910 \ldots \ldots . . . . . . .53$

XXXV. Farm Mortgages, Utah and the United States, $1910 \ldots \ldots . . . .54$

XXXVI. Average Labor Income, 52 Farms, Hyde Park, $1914 \ldots \ldots \ldots . . .55$

XXXVII. The Farmer's Pay for Management and Risk or Responsi-

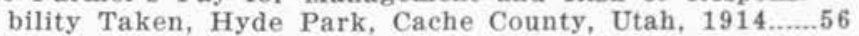

XXXVIII. Business Statement of the Average of 10 Better-paying Farms of the Hyde Park Area, Cache County, Utah, 1914, Showing Type of Farming and Labor Income........57

XXXIX. Business Statement of Farms of Hyde Park Area, Cache County, Utah, 1915, Showing Type of Farming.................58

XL. Business Statement of Farms of Hyde Park Area, Cache County, Utah, 1916, Showing Type of Farming ................59

XLI. Labor Incomes of 32 Farmers, Hyde Park, Cache, County,

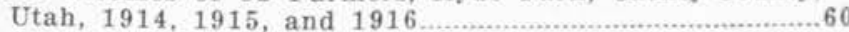

XLII. Labor Income of Utah Farmers, 1909 (1910 U. S. Census) ....62

XLIII. Tenure and Use of Farm Land per Farm, 50 Farms, Beaver, Beaver County, Utah, 1914 ........................................64

XLIV. Size of Farm Family and Number of Cows Kept, Beaver, Beaver County, Utah, 1914 .............................................66 66

XLV. Size of Family, Acres Sugar-beets Raised, and Cows Milked, Monroe, Sevier County, Utah, 1914 …........................69 69

XLVI. Tenure and Use of Farm Land per Farm, 66 Farms, Monroe, Sevier County, Utah, 1914 ...................................69

XLVII Tenure and Use of Farm Land per Farm, 72 Farms, Sandy, Salt Lake County, Utah, 1914........................................ 71

XLVIII. Size of Farm Family, Acres Sugar-beets Raised and Cows Milked, Sandy, Salt Lake County, Utah, 1914 ...............72

XLIX. Tenure and Use of Farm Land per Farm, 38 Farms, Ferron,

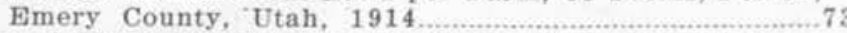

L. Size of Farm Family, Number Milk and Beef Cows Kept, Ferron, Emery County, Utah, 1914 ................................74

LI. Tenure and Use of Farm Land per Farm, 26 Farms, Wellington, Carbon County, Utah, 1914............................ 75

LII. Size of Farm Family and Milk Cows Kept, Wellington, Car-

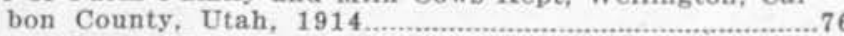

LIII, Size of Farm Family and Number of Milk Cows Kept, Hinckley, Millard County, Utah, 1914 ............................7?

LIV. Tenure and Use of Farm Land per Farm, 59 Farms, Hinckley, Millard County, Utah, 1914 .....................................77

LV. Size of Farm Family, Acres Sugar-beets Raised, and Cows Milked, Pleasant Grove, Utah County, Utah, $1916 \ldots \ldots \ldots . .79$

LVI. Tenure and Use of Farm Land per Farm, 56 Farms, Pleasant Grove, Utah County, Utah, 1916. 


\section{TABLES IN APPENDIX}

Table

Title

Page

I. Business Factors of Farms of Hyde Park Area, Cache County, Utah, 1914, Showing Type of Farming ……........ 97

II. Business Factors of Farms of Hyde Park Area, Cache County, Utah, 1915, Showing Type of Farming......... 98

III. Business Statement of 10 Better-paying Farms of the Beaver Area, Beaver County, Utah, 1914, Showing

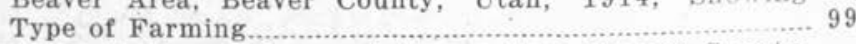

IV. Business Factors of Farms of Beaver Area, Beaver County, Utah, 1914, Showing Type of Farming...................... 100

v. Business Statement of Farms of Beaver Area, Beaver County, Utah, 1915, Showing Type of Farming................10

VI. Business Factors of Farms of Beaver Area, Beaver County, Utah, 1915, Showing Type of Farming.......................... 102

VII. Business Statement of Farms of Beaver Area, Beaver County, Utah, 1916, Showing Type of Farming ............103

VIII. Business Statement of 10 Better-paying Farms of the Monroe Area, Sevier County, Utah, 1914, Showing Type of Farming

IX. Business Factors of Farms of Monroe Area, Sevier County,

- Utah, 1914, Showing Type of Farming

X. Business Statement of Farms of Monroe Area, Sevier County, Utah, 1915, Showing Type of Farming...........106

XI. Business Factors of Farms of Monroe Area, Sevier County, Utah, 1915, Showing Type of Farming........................107

XII. Business Statement of Farms of Monroe Area, Sevier County, Utah, 1916, Showing Type of Farming.............10

XIII. Business Statement of 10 Better-paying Farms of the Sandy Area, Salt Lake County, Utah, 1914, Showing Type of Farming

XIV. Business Factors of Farms of Sandy Area, Salt Lake County, Utah, 1914, Showing Type of Farming ..............110

XV. Business Statement of Farms of Sandy Area, Salt Lake County, Utah, 1915, Showing Type of Farming ..............111

XVI. Business Factors of Farms of Sandy Area, Salt Lake County, Utah, 1915, Showing Type of Farming ……...... 112

XVII. Business Statement of Farms in Sandy Area, Salt Lake County, Utah, 1916, Showing Type of Farming …....113

XVIII. Business Statement of 10 Better-paying Farms of the Ferron Area, Emery County, Utah, 1914, Showing

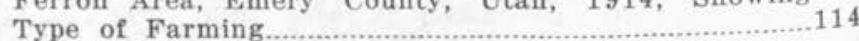

XIX. Business Factors of Farms of Ferron Area, Emery County, Utah, 1914, Showing Type of Farming .......................115

XX. Business Statement of Farms of Ferron Area, Emery County, Utah, 1915, Showing Type of Farming.............116

XXI. Business Factors of Farms of Ferron Area, Emery County, Utah, 1915, Showing Type of Farming.

XXII. Business Statement of Farms of Ferron Area, Emery County, Utah, 1916, Showing Type of Farming ..............11s

XXIII. Business Statement of 10 Better-paying Farms of the Hinckley Area, Millard County, Utah, 1914, Showing Type of Farming

XXIV. Business Factors of Farms of Hinckley Area, Millard County, Utah, 1914, Showing Type of Farming ..............120

XXV. Business Statement of Farms of Hinckley Area, Millard County, Utah, 1915, Showing Type of Farming ..............121

XXVI. Business Factors of Farms of Hinckley Area, Millard County, Utah, 1915, Showing Type of Farming ……......122 
XXVII. Business Statement of Farms of Hinckley Area, Millard County, Utah, 1916, Showing Type of Farming...............123

XXVIII, Business Statement of Farms of Pleasant Grove Area, Utah

County, Utah, 1916, Showing Type of Farming..............124

XXIX. Average Farm Prices in Utah, December 1, 1880-1918.....125

XXX. Tenure and Use of Farm Land, 32 Farms, Hyde Park,

Cache County, Utah, 1914, 1915, and 1916.

XXXI. Tenure of Farms in Utah, by Counties, $1880 \ldots \ldots \ldots . . . . . . . . . .127$

XXXII. Tenure of Farms in Utah, by Counties, $1890 \ldots \ldots \ldots \ldots \ldots \ldots \ldots . . . . .128$

XXXIII. Tenure of Farms in Utah, by Counties, $1900 \ldots \ldots \ldots \ldots \ldots \ldots \ldots . . .129$

XXXIV. Tenure of Farms in Utah, by Counties, by Percentages,

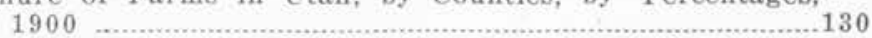

XXXV. Tenure of Farms in Utah, by Counties, $1910 \ldots \ldots \ldots \ldots \ldots \ldots . . . . . .131$

XXXVI. Percentage of all Farms Operated by Owners, Utah, 1889 and 1909

XXXVII. Dates of Farm Crop Operations in 8 Areas of Utah..........133

XXXVIII. Average Yields of 7 Important Utah Crops............................134

XXXIX. Percentage Yield, or Crop Index, Based on Average U. S. Yields

XL. Percentage Yield, or Crop Index, Based on Average Iowa

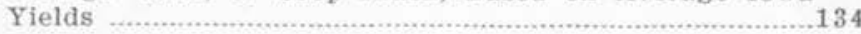




\section{BIOGRAPHICAL}

Birth and Marriage.-Edgar Bernard Brossard was born on the Brossard Stock Ranch, Oxford, Bannock County, Idaho, April 1, 1889. Son of Alphonse Aimable and Mary Catherine (Hobson) Brossard.

Married Laura Parkinson Cowley, daughter of Mathias Foss and Luella Smart (Parkinson) Cowley, August 25, 1915.

School and Collegiate Record.-Attended the grade schools at $\mathbf{0 x}$ ford, Idaho; and Ogden and Logan, Utah; and did high school and college work at the Utah Agricultural College, 1904-5 and 1906-1911 inclusive, where he was granted the Batchelor of Science degree in General Science with a major in Economics, June, 1911.

September 1916 to June 1917 he was a graduate student in Agricultural Economics and Farm Management at the University of Minnesota, where he was granted the Master of Science degree in June 1917 . September 1917 to June 1918 he did graduate work in Agricultural Economics and Farm Management at Cornell University. From June 1918 to September 1919 he was again registered in the Graduate School of the University of Minnesota, from which school he was granted the degree of Doctor of Philosophy (Ph.D.) June 1920, with a major in Agricultural Economics and a minor in Farm Management.

Teaching Experience.- He was instructor in mathematics at the Utah Agricultural College, 1909-1910. He was State Farm Management Demonstrator for Utah for two years and three months, September 1, 1914 to August 31, 1916, and again from June 1, 1917 to August 31, 1917. At the University of Minnesota, 1916-17 he was assistant Farm Management Demonstrator and in 1918-19 he was instructor in Farm Management. From September 1, 1919 to date he has been Professor of Farm Management at the Utah Agricultural College and in charge of Farm Management Investigations at the Utah Agricultural Experiment Station.

Organizations and Fraternities.- He is a member of the American Farm Economic Association, The National Irrigation and Drainage Congress, The Utah Educational Alpha Zeta, (a professional agricultural fraternity), Gamma Sigma Delta (an honorary agricultural fraternity) and Phi Kappa Phi (an honorary scholastic fraternity).

Other Activities.- In undergraduate years he took part in college activities. He was the first "Four-letter" athlete of the Utah Agricultural College, having won four offial sweaters in football, basketball, baseball, and track, and one year was captain of the football team, and another year manager of basketball. He took part in college dramatics and was on the editorial staff of the college paper as well as class president of the graduating class 1911.

His work and studies while not in college, have permitted him to travel and become somewhat familiar with the States of the United States lying West of the Mississippi River and Minnesota, Illinois and New York. He studied thirty-two months in Europe, October 1911 to May 1914 , and while there visited the large cities and some of the most interesting parts of England, France, Germany, Switzerland, Holland, and Belgium. Headquarters while in Europe were at Paris, France, where he learned to read, write, and speak the French language. 